Viviane Domingues

\title{
Turismo e Automobilismo: efeitos da Fórmula 1 em São Paulo
}


Viviane Domingues

\section{Turismo e Automobilismo: efeitos da Fórmula 1 em São Paulo}

Tese apresentada à área de concentração: Relações Públicas, Propaganda e Turismo, da Escola de Comunicações e Artes da Universidade de São Paulo, como exigência parcial para obtenção do título de Doutor em Ciências da Comunicação, sob a orientação da Profa. Dra. Olga Tulik 


\section{Turismo e Automobilismo: efeitos da Fórmula 1 em São Paulo}

Viviane Domingues

Banca Examinadora

Presidente:

$1^{\circ}$. Membro:

$2^{\circ}$. Membro:

$3^{\circ}$. Membro:

$4^{\circ}$. Membro:

São Paulo, de de 2007 
"Se você estiver seguindo seu próprio caminho, as coisas virão até você. Como é seu próprio caminho, e ninguém o percorreu antes, não existe um precedente; logo, tudo que acontece é uma surpresa, na hora certa".

Joseph Campbell 
Aos meus queridos pais, Antonio, obstinado e astuto, e Emília, uma heroína, pela dedicação, pela sabedoria de vida e pelo amor incondicional.

Sem eles, minha vida não teria sentido. 


\section{Agradecimentos}

De modo simples, porém, verdadeiro, quero expressar a minha gratidão a todos aqueles que acompanharam o longo período dedicado ao doutorado. Sem o apoio, principalmente, não teria conseguido passar pelas situações críticas e pelos desafios que esse período me impôs. Exercitei, sem dúvida, a disciplina, o autocontrole, a paciência e a perseverança. Faltam palavras...

À Profa. Dra. Olga Tulik, pela oportunidade de desenvolver esta pesquisa. O envolvimento despretensioso e sempre amigo; a sabedoria na lida com a pessoa teimosa e dispersiva que sempre fui; sua habilidade nos momentos do colóquio; sua prestimosa atenção mostrando-me os caminhos mais práticos e "racionais"; seu aprendizado que se aplica em outras circunstâncias da vida; sua dedicação nos momentos de extrema dificuldade; e, sobretudo, seu amor pela docência...

Ao Prof. Geoffrey Hewings, diretor do REAL - Regional Economics Application Laboratory da Universidade de Illinois, nos Estados Unidos, pela oportunidade de desenvolver pesquisa, por proporcionar o intercâmbio cultural e pela gentileza.

Ao Alfredo Rômulo Tambucci pela oportunidade de desenvolver o lado profissional durante a organização do Grande Prêmio de Fórmula 1, em 1997, meu primeiro contato com a área de eventos e com o automobilismo.

Aos diversos profissionais e à comunidade de Interlagos por terem contribuído com informações e material necessário.

Aos professores da ECA, especialmente o Prof. Dr. Mário Jorge Pires, pelos conselhos e incentivo.

À terapeuta Maria José Colletti e ao psiquiatra Dr. Roni Broder Cohen, pela retomada de meus estudos.

Às amigas e amigos, pelo carinho.

Ao mano Edson Paulo Domingues que mostrou, mais uma vez, a sua capacidade de ser amigo e solidário. 
Aos meus amados pais, D. Emília e Sr. Domingos, incansáveis trabalhadores, pelo resguardo, pela solidariedade e pelo sentimento familiar que tanto me protegem.

A Deus, meu refúgio... 


\section{Resumo}

Esta pesquisa aborda o Turismo e o Automobilismo e os efeitos da Fórmula 1 em São Paulo. Embora existam referências pontuais, poucos estudos existem sobre esses temas que ainda não despertaram 0 interesse dos estudiosos de Turismo.

Este estudo, fundamentado em obras relacionadas ao esporte em geral, aos eventos esportivos, em informações da internet, em jornais e revistas e, principalmente, em pesquisa de campo partiu da investigação do esporte através dos tempos, da estrutura e organização do automobilismo para chegar ao Autódromo Municipal José Carlos Pace e à análise dos efeitos da Fórmula 1 em São Paulo.

Com base nas abordagens, na literatura, nas análises elaboradas e discussões apresentadas, concluiu-se que a Fórmula 1 em São Paulo gera efeitos que, em parte, podem ser explicados pela visibilidade do Grande Prêmio na mídia. 


\section{Abstract}

This research examines Tourism and Automobilism and impacts of Formule 1 Grand Prix in São Paulo. Althought it has been indications, few studies about the subject have not been emerge yet topic of expertise of Tourism.

This research, based on works about sport, sport events, internet datas, papers and, mainly, field survey begun investigations sports through times, its structure and organization of Automobilism in order to work Autódromo Municipal José Carlos Pace and analyses of effects of Formule 1 in São Paulo.

Considering approaches, literature, analyses made and discussions showed, the conclusion is that Formule 1 in São Paulo generates effects that, partly, can be explained by visibility of Grand Prix in media. 


\section{Turismo e Automobilismo: efeitos da Fórmula 1 em São Paulo}

\section{SUMÁRIO}

Introdução

\section{Esportes, Turismo e Eventos Esportivos: o Automobilismo}

1.1. Abordagens na Literatura

1.2. O esporte através dos tempos

1.3. Estrutura e organização do automobilismo e das competições

1.4. Antigomobilismo: a valorização da cultura

1.5. Fora-de-estrada ou off-road: envolvimento do esporte com o turismo

2. O Autódromo Municipal José Carlos Pace e a Fórmula 1 em São Paulo

2.1. O início, as transformações da infra-estrutura e as corridas automobilísticas

2.2. O público da Fórmula 1: caracterização, distribuição espacial e segurança

2.3. Preparação do autódromo para o evento

\section{Análise dos Efeitos do Grande Prêmio na capital}

3.1. Patrocinadores do evento e das equipes

3.2. Oferta direta de produtos e serviços

3.3. Lazer e entretenimento: o erotismo

3.4. Acesso e segurança

3.5. Eventos paralelos

3.6. Aspectos político-econômicos

\section{Considerações Finais}

Bibliografia 


\section{Lista de Figuras}

Figura 1 - Federações de Automobilismo filiadas à CBA

Figura 2 - Clubes de Antigomobilismo filiados à FBVA

Figura 3 - Clubes de Jeep e de Off-road no Brasil

Figura 4 - Eventos de Automobilismo no Estado de São Paulo

Figura 5 - Imagem de satélite da cidade de São Paulo com a localização do Autódromo de Interlagos, situado entre as represas Guarapiranga e Billings

Figura 6 - Imagem de satélite do Autódromo de Interlagos e adjacências

Figura 7 - Acampamentos no Autódromo de Interlagos na década de 1970

Figura 8 - Arquibancadas do Grande Prêmio de Fórmula 1 de 1997

Figura 9 - Autódromo de Interlagos e setores vip na Fórmula 1

Figura 10 - Uso indiscriminado de qualquer espaço que oferecesse visibilidade

Figura 11 - A Unidas, locadora oficial da Fórmula 1, enfatizou que seus clientes vivem a 300 $\mathrm{Km} / \mathrm{h}$

Figura 12 - A cerveja oficial da Fórmula 1 fez o lançamento da Nova Schin, um novo produto, com rótulo comemorativo que evoca a Fórmula 1 (2004)

Figura 13 - Bridgestone, fabricante de pneus e patrocinadora das equipes Ferrari, evidenciou a conquista de seis títulos mundiais até 2004 anunciando a "paixão pela excelência"

Figura 14 - A Petrobrás, que forneceu o combustível para a equipe BMW Williams, estabeleceu analogia de seu produto com a energia dos pilotos

Figura 15 - Os postos da rede Shell divulgaram concursos de prêmios Ferrari a quem abastecesse no local, o que justifica-se pelo apoio da Shell às equipes da Ferrari que participavam da Fórmula 1 de 2004

Figura 16 - O combustível diferenciado da Shell, Shell V-Power, é colocado como a gasolina campeã da Fórmula 1 pelo êxito das equipes patrocinadas

Figura 17 - A empresa DHL, parceira global da Fórmula 1, ligada ao trabalho de logística oficial, evidenciava a velocidade de seu negócio, destacando as cores da empresa na Fórmula 1 através da bandeira quadriculada, o que mostra a participação da empresa na vitória dos competidores

Figura 18 - Advertência antifumo, uma medida do Ministério da Saúde, no Autódromo de Interlagos (2004)

Figura 19 - Escola de Pilotagem Interlagos, uma das três escolas existentes no bairro de Interlagos, as únicas do gênero na capital paulista

Figura 20 - Banca de artesanato em madeira localizada próximo à movimentação de bares e lanchonetes em frente ao autódromo 
Figura 21 - "Flanelinhas" e guardadores de carros que todos os anos estão presentes nos arredores do autódromo de Interlagos

Figuras 22 e 23 - Ambulantes oferecem produtos consumidos, em geral, por pessoas de baixa renda

Figuras 24 e 25 - Disponibilidade de TV nos estabelecimentos comerciais oferecem à sua clientela a possibilidade de assistir à Fórmula 1

Figura 26 - Visão do circuito de Interlagos proporcionada por um dos poucos espaços ainda desocupados na avenida Interlagos, adjacente ao circuito

Figura 27 - Público que afluiu ao autódromo em razão da Fórmula 1 acompanhava o evento, externamente, em espaços ainda desocupados

Figura 28 - Fãs do automobilismo que afluem ao autódromo mesmo sabendo que não têm acesso

Figuras 29 e 30 - Fachada de uma drogaria que foi utilizada, em 2004, de forma oportunista, durante a Fórmula 1, divulgando apelo erótico para o entretenimento dos visitantes

Figuras 31-32 - O prazer de "ter uma noite de $1^{\circ}$. Mundo", na Café Millenium, ou uma "noite com mais prazer", tomando um simples café na Café Photo, eram as mensagens das casas noturnas distribuídas por outdoors das principais ruas e avenidas da capital

Figuras 33 - Mensagem associada diretamente à Fórmula 1 na propaganda da boate Bahamas, próximo à ponte Cidade Jardim

Figuras 34 e 35 - Sinalização da CET revela formas de circulação adequadas aos diversos tipos de público, como credenciados, de setores vip, de atendimento médico e pedestres

Figuras 36 e 37 - Sinalização da CET define espaços destinados exclusivamente ao estacionamento de automóveis e de ônibus, além aos táxis credenciados

Figuras 38 e 39 - Vias interditadas e faixas exclusivas para ônibus: práticas da CET para favorecer o fluxo de veículos nas ruas próximas ao autódromo de Interlagos

Figura 40 - Espaço destinado a grupos de policiais designados para a segurança do autódromo

Figura 41 - Rua adjacente ao autódromo de Interlagos que ficou congestionada depois de um dia de treinos da Fórmula 1 de 2006, sendo os motoristas surpreendidos por assaltantes

Figura 42 - Latas e papéis, principalmente, são coletados por pessoas de baixa renda para reciclagem

Figura 43 - Divulgação do Salão do Automóvel, no Parque do Anhembi, feita na avenida dos Bandeirantes

Figura 44 - Divulgação da Feira do Automóvel, no Transamérica Expo-Center, feita junto à ponte Jurubatuba

Figura 45 - Divulgação da exposição "Senna Experience" na avenida dos Bandeirantes

Figura 46 - "Capital Mundial do Automobilismo", uma divulgação promovida pela Prefeitura de São Paulo em 2004 


\section{Introdução}

Símbolo de liberdade e mobilidade, o automóvel faz parte do cotidiano de todas as pessoas, indistintamente, da mesma forma que as viagens e o turismo. Esta pesquisa trata de Turismo e Automobilismo, com ênfase nos efeitos da Fórmula 1 em São Paulo. A partir de abordagens gerais, chegou-se ao caso específico do Autódromo Municipal José Carlos Pace, localizado na capital paulista, que sedia, anualmente, a Fórmula 1 ou Grande Prêmio do Brasil de Fórmula 1, evento esportivo automobilístico que chega a destacar-se no panorama mundial. Esta abordagem teve como ponto de partida os temas esporte, turismo e evento esportivo para chegar ao automobilismo.

Justifica-se a relevância desta pesquisa considerando-se a importância do tema e a escassez bibliográfica do tema central e, mesmo, de outros paralelos como turismo e esporte, turismo esportivo e turismo e eventos esportivos. Além disso, deve-se considerar a importância desse evento no panorama nacional e a necessidade de conceituar, caracterizar e analisar as relações do automobilismo com o turismo que vem gerando modalidades significativas para a área acadêmica e profissionalizante do Turismo.

A literatura existente, em grande parte internacional, resulta de pesquisas acadêmicas desenvolvidas em Universidades e de relatórios de departamentos do governo ou de empresas privadas de consultoria. De um modo geral, a preocupação dos especialistas está centrada nas possibilidades de realização dos eventos esportivos e na verificação da viabilidade dos investimentos realizados. No exterior, alguns estudos são patrocinados por empresas privadas, principalmente instituições bancárias que direcionam sua análise para a captação de investidores. Em alguns países, entretanto, algumas Universidades têm manifestado preocupação com os efeitos desses eventos esportivos.

No Brasil, a literatura é ainda mais escassa. Não foram localizadas pesquisas específicas sobre turismo e automobilismo, nem mesmo sobre sua caracterização e seus efeitos. A FIPE - Fundação de Pesquisas Econômicas da USP representa uma exceção nesse sentido, pois, em 2004, iniciou estudos sobre os efeitos econômicos do Grande Prêmio de Fórmula 1. Essa pesquisa, 
em conjunto com a Anhembi Turismo e Eventos, atual SPTuris, procurou estabelecer comparações com outros eventos realizados em São Paulo.

O panorama da literatura nacional e internacional registra informações pontuais que se referem ao turismo esportivo como uma modalidade relacionada aos grandes eventos, sem mencionar os eventos automobilísticos ou o turismo automobilístico. Essas questões não aparecem ainda nas obras acadêmicas, razão pela qual justifica-se a necessidade de colocar em discussão assuntos como esses.

A escolha de São Paulo justifica-se porque esta cidade enquadra-se nos parâmetros de aglomerações de grande porte, sendo a capital e seu entorno a área mais urbanizada do país que apresenta condições de infra-estrutura capaz de abrigar mega-eventos esportivos. Além disso, São Paulo possui público e empresas com motivações convergentes para a realização do Grande Prêmio de Fórmula 1 - um evento automobilístico, que confere ao país visibilidade internacional. No entanto, pouco se conhece sobre os efeitos gerados por esse evento.

A motivação para realizar esse trabalho teve origem na observação empírica de fatos reais pouco estudados no meio acadêmico que estimularam o interesse e a busca por fundamentação teórico-metodológica. Além disso, a experiência de participar da organização da Fórmula 1, em 1997, despertou o interesse para a atratividade desse evento e para os efeitos da Fórmula 1 na rotina, na infra-estrutura, no sistema de transporte urbano da capital e, sobretudo, no entorno do Autódromo Municipal José Carlos Pace. Em 2001, um novo estímulo indicou a relevância desse tema, quando houve oportunidade de estagiar no REAL - Regional Economics Application Laboratory, na Universidade de Illinois, nos Estado Unidos, como student visitor. Nessa Universidade foi realizado o levantamento bibliográfico sobre turismo esportivo e temas correlatos e tomar conhecimento de metodologias específicas.

Essa pesquisa tem por objetivo geral contribuir para o conhecimento do Turismo Automobilístico como um segmento do Turismo Esportivo e dos efeitos da Fórmula 1 em São Paulo. Entre os objetivos específicos estão: caracterizar o automobilismo e revelar suas relações com o turismo; analisar o turismo e os eventos esportivos; identificar a estrutura e a organização do automobilismo; apresentar o autódromo onde se realiza a Fórmula 1. 
Da observação empírica, da leitura atenta da bibliografia, das entrevistas informais e do vasto material disponível na internet, resultaram indagações que levaram à elaboração do problema desta pesquisa: quais os efeitos da Fórmula 1 em São Paulo, especificamente no entorno do Autódromo José Carlos Pace, capazes de alterar o cotidiano dos moradores da capital? Para responder a essa questão, considerando a repercussão do evento na mídia e a publicidade que ocupa todo o entorno do espaço onde se realiza a Fórmula 1, foram elaboradas as seguintes hipóteses:

- da visibilidade da Fórmula 1 decorre o exagero da publicidade no entorno do autódromo;

- a Fórmula 1 estimula a realização de eventos ligados ao automobilismo na cidade de São Paulo;

- medidas restritivas relacionadas à divulgação de certos produtos podem comprometer a Fórmula 1.

Para alcançar os objetivos e responder à questão proposta foi feito, inicialmente, um levantamento bibliográfico para resgatar obras e artigos de caráter geral e específico, principalmente nos acervos das bibliotecas da Universidade de São Paulo e da Universidade de Illinois, nos Estados Unidos. Junto à SEET - Secretaria de Esportes e Turismo de São Paulo foram consultados documentos sobre a história do autódromo e sobre o calendário de eventos automobilísticos nele realizados. Recorreu-se à internet para obter notícias do automobilismo, sites de organismos do esporte, bem como o levantamento de reportagens de grande circulação no mundo inteiro, que forneceram informações factuais do histórico do automobilismo no Brasil. A internet viabilizou contatos com organismos internacionais, tais como o STIC Sport Tourism International Council, a FIA - Federação Internacional de Automobilismo e o Banco La Salle, que disponibilizaram informações.

O trabalho de campo, basicamente efetuado em outubro de 2004, compreendeu entrevistas não estruturadas aplicadas a espectadores, esportistas, organizadores do evento e agentes de viagens que acompanhavam grupos de visitantes. Numa outra etapa, foram entrevistados vendedores 
ambulantes, comerciantes fixos, moradores, responsáveis pelo trânsito e pela segurança. Os resultados colhidos nessas entrevistas foram analisados e classificados conforme os temas a serem discutidos. Numerosas fotos registraram efeitos da Fórmula 1 no entrono do autódromo e constituíram base para discussão de questões pertinentes a esse tema.

Para entender a distribuição dos clubes de automobilismo no Brasil, foi elaborada uma listagem dessas associações junto à CBA - Confederação Brasileira de Automobilismo, à FBVA - Federação Brasileira de Veículos Antigos e às revistas especializadas. As informações constantes nessas fontes foram transformadas em dados numéricos e devidamente localizados no espaço brasileiro. O mesmo procedimento foi adotado para elaborar a distribuição dos clubes de antigomobilismo e daqueles relacionados ao fora-de-estrada ou offroad. O Autódromo Municipal José Carlos Pace foi localizado a partir do Google Earth que permitiu a visualização detalhada desse espaço e do seu entorno. $\mathrm{Na}$ representação mencionada foram inseridas informações esclarecedoras de pontos de referência necessários para o entendimento desta pesquisa.

Esta pesquisa está estruturada em três capítulos. O primeiro, fornece a fundamentação teórica necessária para o entendimento do esporte, do turismo, dos eventos esportivos e do automobilismo. O segundo capítulo trata do espaço onde se realiza a Fórmula 1, relatando o início, as transformações ocorridas, a distribuição do público e a preparação do autódromo para o evento. Finalmente, o terceiro capítulo analisa especificamente os efeitos do Grande Prêmio na capital paulista, registrando a complexidade de interações que se estabelecem entre população, visitantes, esportistas, organizadores, comerciantes, poder público, patrocinadores do evento e equipes. 


\section{Esportes, Turismo e Eventos Esportivos: Automobilismo}

\subsection{Abordagens na Literatura}

A discussão relacionada ao turismo esportivo partiu de uma busca da literatura nacional e internacional. Constatou-se que, no Brasil, poucos estudos existem sobre o tema, diversamente do que acontece no exterior. As obras nacionais trazem referências pontuais e, na maioria das vezes, desvinculadas do turismo esportivo e do automobilismo, que pouca contribuição oferecem a esta pesquisa. Deve-se, porém, destacar como uma exceção a obra de Haddad, Kadota e Rabahy que trata do Grande Prêmio do Brasil de Fórmula 1 em São Paulo. Essa obra apresenta os impactos econômicos desse evento com estimativas dos efeitos diretos e indiretos, sendo, portanto, imprescindível para esta pesquisa, o que será revelado em maiores detalhes no item referente a política e economia (Haddad; Kadota; Rabahy, 2004).

Outras obras existem vinculadas diretamente ao automobilismo, especificamente à Fórmula 1 em outros países. Burns e Mules (1989) ao avaliar o Grande Prêmio de Fórmula 1, em Adelaide (Austrália), em 1985, também realizaram um estudo econômico envolvendo custos e benefícios sociais para o governo. Os autores registraram a criação de novas receitas e do valor agregado gerado pela introdução de novos gastos, inclusive turísticos, na economia regional. Lembram esses autores, assim como Haddad, Kadota e Rabahy acima mencionados, que esse fato não teria ocorrido sem a realização do Grande Prêmio.

Arnold, Fischer, Hatch e Paix (1989) também abordaram o automobilismo. Esses autores relacionaram a realização da Fórmula 1 de Adelaide (Austrália) aos acidentes de carro nas estradas, analisando, nesse contexto, a filosofia dos grandes eventos esportivos automobilísticos. Outro autor que trata da Fórmula 1 é Santos (2003), jornalista português, que descreveu a história da Fórmula 1.

Ainda na literatura internacional, Littlewood e Harry (1989) discutiram o uso do parque público, numa área residencial e arborizada de Melbourne, na Austrália. Esse local, por ocasião da Fórmula 1, durante o período de 1985 a 
1995, foi preparado com pistas, arquibancadas e demais dependências exclusivamente para o evento. Naquele momento, surgiram manifestações populares desfavoráveis suscitadas pela incompreensão sobre a tomada de decisão sem consultar a opinião pública. Os autores mostraram que, além dos benefícios econômicos, devem ser considerados os custos sociais tais como tráfego, congestionamentos, acidentes, ruídos, vandalismo e assalto. Esses, de certo modo, podem contrariar os benefícios sociais da promoção e dos investimentos públicos visando o turismo e os negócios, sendo menos perceptíveis e desconsiderados no planejamento.

A principal fonte de pesquisa sobre os trabalhos no exterior foram, sem dúvida, as revistas científicas, dentre elas as mais tradicionais, tais como Annals of Tourism Research, Tourism Management, Estúdios Turísticos, Journal of Leisure Research, e as mais recentes, como é o caso da Festival Management \& Event Tourism e da Journal of Sport Tourism. Estas bases de referência permitiram o acesso às obras internacionais e foram, em sua grande maioria, compiladas das fontes originais em 2002, disponíveis numa das maiores bibliotecas do mundo - a biblioteca central da Universidade de Illinois, nos Estados Unidos. Alguns desses periódicos já disponibilizam seus artigos pela internet. Esses estudos vêm sendo realizados há mais de 20 anos por várias instituições de ensino e pesquisa. Assim, merece destacar o papel dos centros de estudos que desenvolvem pesquisas aplicadas, como é o caso do REAL Regional Economics Application Laboratory, da Universidade de Illinois, nos EUA, e do Centre for Regional Economic Analysis, da Universidade da Tasmânia, na Austrália.

Departamentos e organismos que congregam estudiosos e profissionais interessados no turismo esportivo estão representados pelo International Sport Tourism Council. Com sede no Canadá, esse órgão mantém uma revista científica (Journal of Sport Tourism) e realizou, desde a sua criação, em 1993, diversos encontros internacionais sobre o tema, sempre articulando convênios, e inaugurou, recentemente, núcleos de estudos específicos sobre o turismo esportivo. Os estudiosos mais entusiasmados e aqueles com iniciativas práticas na educação em turismo, apontam o turismo esportivo como o mais recente segmento de pesquisa. Desde as primeiras edições da revista, foi possível conhecer estudos e reflexões sobre o turismo esportivo em lugares remotos. 
Standenven e De Knopp (1998) postulam que há um número crescente de cursos de graduação e pós-graduação oferecidos atualmente em muitas áreas acadêmicas associadas com o turismo e o esporte, o que não acontece apenas na América do Norte e na Europa, mas também na Austrália e em outras partes do mundo, justificando, assim, a obra desses autores que mostrou uma perspectiva internacional da disciplina.

Standenven e De Knop (1998) mostram que congressos, seminários e workshops sobre esporte e turismo têm sido documentados, desde 1971, quando conjuntamente, o ICSSPE - International Council for Sport and Physical Education e o ICHPER - International Council for Sport Science, Health and Physical Education and Recreation patrocinaram $01^{\circ}$. congresso especificamente dirigido ao turismo esportivo, sediado em Israel, em 1986.

Conforme Kurtzman e Zauhar (2000), o Turismo Esportivo tem mostrado oferecer impacto econômico significativo, não apenas por sediar grandes eventos esportivos mas também por desenvolver núcleos receptores de esportes e atrações esportivas. Mais recentemente, o marketing aumentou o turismo esportivo pelos países, regiões e comunidade o que sugestiona potencial para melhorar a receita do turismo. A pequena popularidade do setor de cruzeiros, um cruzeiro de cerimônia dos esportes tornou-se um importante elemento do turismo esportivo. Cada uma dessas vantagens contribui aos impactos do turismo esportivo. A importância da área do turismo esportivo é atualmente bem reconhecida, dada a criação de uma associação profissional, o STIC - Sport Tourism International Council.

As parcas iniciativas envolvendo as duas áreas - esporte e turismo, tanto no meio acadêmico como em âmbito governamental, são o reconhecimento dessa relação como um fator catalisador (Sparrow,1989; Law 1996; Gratton, Dobson e Shibli, 2000), ou seja, um elemento que modifica a velocidade de uma reação, neste caso, para o desenvolvimento sustentável que o turismo esportivo permite alcançar. Hall mencionou que o Grande Prêmio faz com que as pessoas se sintam bem e observou que esse resultado foi melhor do que os efeitos econômicos tangíveis. Segundo ele, o governo provavelmente continuará ávido por se associar ao sucesso do evento e subsidiá-lo permite enriquecer a imagem local. Conforme Hall (1987), há possibilidade, entretanto, de ocorrerem efeitos negativos que podem anular os benefícios desse grande evento (Hall, 1987). 
A obra que trata exclusivamente do tema - Sport Tourism - foi publicada, em 1999, por Standeven e De Knop, pesquisadores do Reino Unido. Dentre os pioneiros que colocaram em pauta o turismo esportivo está LopezBermejero que publicou em 1967, em Madrid, uma obra - El Desporte como Promoticion de Turismo. O próprio autor achava esse título um tanto pretensioso, embora o assunto fosse instigante, o que, ainda hoje, empolga tanto pesquisadores, como governantes e profissionais da área.

Na Espanha, Férnandez Fuster (1971) dedicou um capítulo de seu livro sobre Teoria e Técnica do Turismo para discorrer sobre os equipamentos esportivos, o esporte turístico e o turismo esportivo, além de esboçar pontos fundamentais sobre as funções dos clubes de esporte, destacou, algumas modalidades mais populares na Europa como o turismo náutico e aquático, o mergulho, a caça e a pesca, os esportes aéreos, o golfe, o hipismo, os esportes de inverno e do gelo. Para o autor, era mais interessante para uma localidade o turismo esportivo do que o esporte-espetáculo, pois ele focalizava o desenvolvimento turístico nos moldes mais tradicionais e não tratava o esporte turístico.

Durante os anos de 1990, alguns temas se destacam como sendo novas tônicas para a época, embora sejam, ainda hoje, atuais quanto à preocupação e às iniciativas do setor privado e dos organismos esportivos. A relação entre esses setores, entendida como recíproca, aparece nas obras de Redmond (1991) e de Standenven e De Knop (1999) como "simbiose".

A obra pioneira em observar e relacionar as ações públicas dos departamentos de turismo e do esporte foi de Glyptis, em 1991, o que até aquele momento estava, e ainda está na maioria dos países, como dissociados por questões de ordem prática e política. A autora analisou a administração pública do esporte e do turismo nos países europeus e mostrou iniciativas de turismo esportivo, considerando especialmente o planejamento urbano e a ampliação da oferta de empregos. Tal como menciona a autora, as áreas do esporte e do turismo, embora aparentemente distintas, são concomitantes. Tanto na vida prática das pessoas como no mercado e nos negócios, essas áreas convergem para ações conjuntas, reunindo os organismos esportivos, as empresas de turismo e a administração pública em iniciativas que atendem à demanda pelo 
turismo e lazer esportivo. Em contrapartida, essas ações consolidam a missão institucional das organizações envolvidas.

Chaspoul (1997) também postula a relação conjugada entre os esportes e o turismo. Ambos se alastram no final da década de 1970, atraindo as classes sociais mais numerosas, constituindo o denominado "esporte para todos" (sport fair) e, no turismo, o que se convencionou chamar "o mundo das viagens". Para exemplificar o elo entre turismo e esporte, esse e outros autores analisaram, sobretudo, as estações de inverno da Europa, dos Estados Unidos e do Canadá.

Cahiers Espaces, uma publicação acadêmica da França, publicou dois volumes que interessam para esta pesquisa. O primeiro que data de 1992 Tourisme d'Aventure - retrata o rally Paris-Dakar, o Raid Gauloises e o Club Camel Aventure, mostrando a dificuldade de delimitações teóricas, a originalidade e a autenticidade dos eventos, as adaptações tecnológicas e o aprimoramento de questões de segurança. Tourisme et Sport, publicado no final da década de 1990, reuniu trabalhos que variam de temas sociológicos, como é o caso de "a sociedade muda, o esporte evolui", a outros, como a explosão dos esportes de aventura, em que se incluem as expedições de $4 \times 4$, os esportes aquáticos, os eventos esportivos, como a Copa do Mundo de Futebol e sua importância para o turismo, além de preocupações e práticas sobre o desenvolvimento local do turismo esportivo.

Trabalhos sobre a distinção entre turismo de aventura, esporte e de saúde (Hall, 1992) foram os primeiros a revelar a tendência para o lazer esportivo. Os temas relacionaram-se à motivação da viagem e aos valores sociais, enfatizando, sempre, a busca pela melhoria da qualidade de vida individual que envolve a participação ativa. Goodrich (1993), por exemplo, discutiu o conceito de turismo de saúde que é praticado em Cuba. Coleman e Isso-Ahola (1993) mostram, por exemplo, o turismo de aventura, especialmente aquele realizado em áreas de interesse ambiental onde vários tipos de esportes automobilísticos são realizados.

Dos vários itens relacionados à avaliação econômica dos eventos esportivos, um deles tem interesse particular para esta pesquisa. Trata-se do estudo de questões sociais da comunidade, relacionados aos eventos automobilísticos e esportivos em geral. Registros sobre os efeitos do turismo em geral são freqüentes na literatura específica. Entretanto, poucas referências 
existem sobre as repercussões do Turismo Esportivo e, menos ainda, sobre o automobilismo, embora alguns autores abordem os efeitos com relação aos eventos em geral. As Olimpíadas, e outros grandes eventos como a Copa do Mundo e eventos de modalidades esportivas populares em outros países, são os casos mais estudados pela literatura e esses objetos de pesquisa permitiram desdobramentos dos temas desenvolvidos por estudiosos de outras áreas.

Os Jogos Olímpicos de Sydney, realizados na Austrália em 2000, foram analisados previamente por Madden (1999) que mostrou as conseqüências da geração de gastos e os principais benefícios que aconteceram principalmente antes e durante o período dos Jogos; Hall e Hodges (1996) relacionaram os possíveis efeitos para a cidade e seus habitantes. As Olimpíadas de Atlanta nos EUA foi estudada por Mihalik (2000) em relação à percepção dos moradores. Arthur e Andrew (1996) investigaram o envolvimento da comunidade na administração de um grande evento, mostrando as razões e os métodos para atrair administradores e patrocinadores.

As Olimpíadas de Inverno realizadas em Calgary, no Canadá, no ano de 1988, foram observadas ao longo dos anos com o monitoramento dos impactos do evento, especialmente em relação à percepção dos moradores locais. Os monitoramentos antes, durante e depois do evento foram realizados por Ritchie e Aitken (1984 e 1985), Ritchie e Lyons (1987 e 1990), Hiller (1989), Ritchie e Smith (1991), Murphy e Carmichael (1991) e Mount e Leroux (1994).

Os Jogos Olímpicos de Inverno realizados em Lillehammer, em Norway, em 1994, foram analisados quanto ao ponto de vista dos espectadores por Flognfeldt (1998), quanto à percepção dos voluntários que trabalharam no evento por Elstad (1996), quanto ao conhecimento, à participação e à identidade dos residentes por Hanefors (2000), quanto a aspectos da aprendizagem e profissionalização no turismo esportivo por Lowendahl (2000), quanto aos impactos nos setores econômicos a longo prazo por Spilling (2000), sobre os efeitos financeiros do evento no setor público por Anderson e Samuelson (2000) e por Hultkrantz (2000) que estabeleceu comparações com outros eventos defendendo a tese de que não existir evento comparável às Olimpíadas.

Hughes (1993) revisou os argumentos para a realização dos Jogos Olímpicos e, em particular, aos efeitos do Turismo e pela possibilidade de regeneração das áreas urbanas. Mules (1993) mostrou que um evento especial 
faz parte de uma estratégia de urbana de renovação ao descrever o processo de organização de evento no Porto de Adelaide, na Austrália, uma região portuária decadente mas com mercado para residentes, para o comércio e para o turismo. Kelly (1989) mostrou o impacto a longo prazo para a arquitetura e o planejamento, sendo o objetivo principal a infra-estrutura e os serviços analisados sob a identidade e as expectativas da comunidade local. Thorne e Munro-Clark (1989) analisou as decisões de planejamento que afetam o ambiente urbano em vários níveis legais observando o planejamento democrático e a proteção ao meio ambiente.

Butler e Grigg (1989) investigaram o processo de candidatura em relação aos dos Jogos Panamericanos de 1991 no Canadá. Wallis-Smith (1989) e Euchner (1999) relacionaram os critérios de seleção para a realização de eventos internacionais. Os projetos de candidaturas das cidades para a realização de mega-eventos foram analisados por Tambucci (2000) cuja proposta foi a de esclarecer sobre o funcionamento do marketing esportivo.

O patrocínio é outro assunto abordado pela bibliografia e mostra-se útil para a compreensão de certas circunstâncias. Além de Tambucci (2000), Crompton (1993, 1995 e 1994) apresentou uma abordagem administrativa para integrar uma parceria de patrocínio, os fatores que estimularam o crescimento do patrocínio de grandes eventos e os benefícios e riscos associados ao patrocínio de grandes eventos. Beritelli, Boksberger e Weinert (2004) examinaram os aspectos financeiros dos grandes eventos esportivos, descrevendo os requisitos financeiros e os recursos de receitas, tendo como finalidade uma comparação dos eventos de forma independente a cada situação, útil para a administração do evento, necessidades financeiras e recursos da receita. Esses autores propõem um modelo de classificação reportando-se aos eventos de esqui no gelo.

Os princípios e práticas da administração do esporte analisados por Masteralexis, Barr e Hums (1998), interessam para o turismo na medida em que esclarecem qual a participação de todos os envolvidos e suas funções administrativas no setor esportivo, de interesse especialmente para esta pesquisa quanto à realização de eventos. Goldblatt (1997) mostrou as qualidades de um líder de evento para chefes e voluntários, está direcionado para a atuação profissional no setor. 
A atenção da mídia, os investimentos, a considerável parcela de participantes e o interesse político evidenciaram, desde 1960, a atração esportiva como "uma paixão internacional de gigantescas proporções" (Standenven e Knop, 1999). Não obstante, o turismo também emergiu como a atividade econômica de maior crescimento e de importância econômica mundial desde 1955 quando a Organização Mundial do Turismo (OMT) começou a registrar o movimento de turistas que anualmente viajavam pelo mundo. Goldblatt questionou, em 1990, por que os eventos esportivos são entretenimento em larga escala e fez observações quanto à programação dos noticiários e da programação esportiva da TV observando a atuação dos atletas e de vários componentes do setor esportivo.

Outro assunto presente nas abordagens da literatura é o evento, já que no turismo esportivo e no automobilismo as principais manifestações são as competições e os calendários esportivos. Numa revisão da literatura, Hall (1992a) mostrou a dificuldade que existe em distinguir termos muito utilizados como hallmark events, mega events e special events. O autor não priorizou os eventos esportivos, mas abordou as Olimpíadas em várias partes de sua obra, cujo conteúdo é especialmente interessante para discutir o aprimoramento do processo utilizado para sediar eventos e maximizar os benefícios, as questões políticas envolvidas e os trabalhos de marketing.

Getz (1991 e 1997) estudou e conceituou os eventos. Em suas obras, foi possível observar sua opinião quanto aos eventos esportivos em que ele menciona a dificuldade para apresentar uma forma de significado global para as competições devido à grande variedade de tipos de eventos. O autor mostrou que os eventos são catalisadores, e que qualquer proposta de eventos deve considerar as políticas públicas. Apresentou a importância dos espectadores, a organização do poder público e dos organismos do esporte e discutiu o grau de envolvimento da mídia e do prestígio dos eventos.

Temas de pesquisas mais recentes mostram o panorama mundial da especificidade e do alcance turismo esportivo, tornando possível estabelecer associações com questionamentos sobre o desenvolvimento dessa atividade num dado país. Downward (2005), da Inglaterra, elaborou uma reflexão crítica e, segundo ele, realista sobre a pesquisa política e administrativa do esporte, do turismo e do turismo esportivo. Gibson, Mclntyre, Mackay e Riddington, também 
da Inglaterra, analisaram os efeitos diretos e indiretos do turismo esportivo no Reino Unido. Descreveram a aplicação de um modelo (The DREAM ${ }^{\mathrm{TM}}$ ) que, além da tradicional análise do valor agregado e das receitas, permitiu aos autores detalhar a variável emprego incluindo o trabalho em tempo integral ou parcial, sexo, nível de habilidade e idade.

$\mathrm{Na}$ Alemanha, Preuss (2005) estudou o impacto econômico dos visitantes de grandes eventos multi-esportivos com a análise insumo-produto, dando enfoque especial à avaliação das oportunidades que incidem sobre as pessoas como a grande multidão que é impedida de entrar para assistir ao evento, aquelas que entram e saem do evento e aquelas que evitam a cidadesede. A Conforme Preuss, a oferta de grandes eventos esportivos cria um alto nível de competição entre as cidades.

Pesquisadores do Canadá e da Nova Zelândia, Hinch e Highan (2005), respectivamente, analisaram a autenticidade das atrações em relação ao esporte e ao turismo. Os autores sustentam que o esporte tem vantagem única sobre outros tipos de atrações turísticas culturais quando considerados o contexto de utilidade e autenticidade aplicando o sistema de atração turística de Leiper. As principais características das atrações esportivas incluem: a incerteza da receita; o papel das disputas atléticas; a natureza cinestésica das atividades esportivas; e a natureza visceral de muitos tipos de envolvimento esportivo. A combinação dessas particularidades aumenta a probabilidade de que, mais do que muitos tipos de atrações turísticas, as atrações esportivas são capazes de impugnar o processo de utilidade.

Daniels e Norman (2005), pesquisadores americanos, estudaram as motivações dos turistas eqüestres, numa corrida de origem colonial realizada na Carolina do Sul (EUA). Enquanto as motivações dos visitantes dos principais eventos esportivos profissionais têm sido documentadas, comparativamente pouco é conhecido sobre os turistas eqüestres. O objetivo do estudo foi verificar as motivações dos fãs, a identificação do esporte e os gastos dos turistas atendidos na corrida anual de obstáculos. Os turistas eqüestres estavam muito mais motivados pelo entretenimento e pelas necessidades de afiliação do grupo.

O trabalho de Hede (2005), pesquisador australiano, revela a influência da televisão como estratégia de marketing turístico. Seu objetivo incluía mensagens veiculadas na mídia televisiva sobre os Jogos Olímpicos de Atenas, 
em 2004. Ele explorou a eficácia da mídia no desenvolvimento de percepções e atitudes positivas da Grécia como um destino turístico. 38,7\% dos entrevistados responderam que a atitude sobre a Grécia como destino turístico mudou como resultado do consumo do televisionamento de Atenas 2004. Considerando que as atitudes dos participantes no atual estudo melhorou, não como um resultado das experiências de primeira mão como o destino, mas como um resultado de suas várias experiências do destino através do consumo de uma mensagem televisiva de um evento especial, o resultado ofereceu visões da eficácia dessa mídia, em particular relacionadas às atitudes positivas referentes à Grécia enquanto destino turístico. O resultado deste estudo poderia ser usado para futuras estratégias de marketing de destino relacionados a eventos.

Costa e Chalip estudaram o uso e o valor do turismo esportivo para a revitalização das economias rurais, o que tem sido amplamente discutido. $O$ estudo emprega métodos etnográficos para explorar as oportunidades e desapontamentos associados com o uso de uma comunidade rural portuguesa onde se pratica o paragliding, associado a um mix de atrações turísticas. Embora o caso tenha sido popularmente identificado como uma aplicação de sucesso do turismo esportivo de aventura para revitalização rural, as observações indicam que o paragliding tem apenas um pequeno impacto na comunidade porque os seus praticantes preferem socializar-se com os outros e, freqüentemente, compram e comem fora da comunidade. Nessa comuniade portuguesa, os praticantes de paragliding buscam atividades para complementar a estadia, e gostaria de trazer suas famílias. A ausência de planejamento de marketing estratégico contribui para o fracasso da comunidade para capturar gastos maiores dos praticantes de paragliding ou para gerar receita de turismo de mercados associados (Costa; Chalip, 2005). Esses dados podem ser aplicados a outras pesquisas em turismo esportivo, sugerindo que o planejamento participativo focado na integração e na alavancagem dos recursos de uma comunidade podem otimizar a função que o esporte desempenha na revitalização do espaço rural.

O turismo na Turquia é visto por Koc (2005) como dependente principalmente dos turistas internacionais que visitam o país no verão para o turismo de sol e mar. A vulnerabilidade do turismo na Turquia e o fato as tendências recentes da demanda turística mostram que há necessidade urgente 
de aprimorar os produtos do turismo, tais como o turismo esportivo. Koc, inicialmente, explora o principal critério usado pelos times de futebol para selecionar uma região e estabelecer acomodações para treinamentos de campo.

Os gastos dos visitantes de três disputas da Copa Mundial de Cricket realizadas em Potchefstroom, na África do Sul, constituem a preocupação de Saayman, Saayman e Pleissis (2005). Isso porque, os eventos esportivos são grandes negócios e os países estão competindo para realizar grandes eventos, pois o dinheiro gerado é considerável. Os resultados da pesquisa indicaram que há fatores diversos que influenciam os gastos, por exemplo, idade, rendimentos, nacionalidade, número de visitantes, apenas para nomear alguns. Os métodos utilizados, entretanto, indicam o valor financeiro e a porção gerada por um evento. Outro trabalho sobre o cricket é de Tyson et al (2005) que descreveram as oportunidades potenciais para o turismo local e concluíram que o evento precisa ser visto como parte de uma estratégia de longo prazo para desenvolver o setor do turismo, e que isso ajudará a estimular o desenvolvimento nacional.

As abordagens na literatura registradas neste item mostram temas variados relacionados ao esporte e ao turismo, geralmente específicos que tratam de casos particularizados, e raramente preocupados com a sua inserção num contexto mais amplo que é o do turismo esportivo e turismo automobilístico. Nesta abordagem predominam autores internacionais, principalmente, dos Estados Unidos e da Austrália. 


\subsection{O Esporte através dos Tempos}

O estudo da origem e do significado das palavras pode ser um caminho adequado para se compreender o início das atividades humanas, reconhecendo a valorização de cada uma delas ao longo dos tempos. Dentre as inúmeras atividades desenvolvidas pelo homem, o esporte apresenta interesse especial para esta pesquisa pela possibilidade que oferece de se entender o Turismo Esportivo. Nessa perspectiva, será destacado o automobilismo e sua contribuição para o turismo.

Há polêmica quanto ao emprego dos vocábulos para tratar de Esporte. Esse é um termo adaptado do inglês sport, que se refere à prática metódica de exercícios físicos, podendo, às vezes, assumir o caráter de diversão e de recreio. A palavra esporte tem algumas variações, como: esportismo, que é o gosto pelo esporte, e esportista, a pessoa que se interessa pelo esporte ou se dedica às ações relativas a ele, ainda que não o pratique. A prática de um esporte envolve a participação ativa em uma modalidade ou a sua apreciação como espectador. Esportistas praticantes diferem, portanto, dos meros espectadores.

Lyra Filho, em sua obra Sociologia do Esporte, discute a propriedade do uso dos vocábulos: desporto, sport ou, simplesmente, esporte. Desporto é um arcaísmo que foi empregado por ocasião da criação da Confederação Brasileira do Desporto, mas até hoje isso se mantém visto o seu emprego em todo material elaborado por essa e outras instituições esportivas brasileiras. Sport é uma palavra inglesa, que foi aportuguesada já há muito tempo, e desport é de uso no francês antigo, significando prazer, descanso, espairecimento e recreio. Foram os ingleses que tomaram a palavra desport por empréstimo dos franceses e a converteram, depois, no vocábulo sport (Lyra Filho, 1973:13). A palavra desporto, entretanto, ainda é utilizada no linguajar jurídico e em algumas obras, razão pela qual, nesta pesquisa, ela ainda está presente, conforme a abordagem do autor.

A palavra jogo é outra que, por associação, está ligada a esporte, sendo, porém, anterior às manifestações culturais. Na ótica de Lyra Filho, a cultura é fator condicionado à existência de sociedade humana. Como explica o autor, o jogo, no sentido lúdico, não revela marcas de cultura, embora traduza algo mais do que as simples atividades mecânicas, como por exemplo, os jogos entre 
crianças e animais. Para esse autor, a celebração parece refletir a influência do jogo nas manifestações de cunho sagrado, que eram o pretexto para a realização de atos festivos (Lyra Filho, 1973:15).

Durante o percurso para a celebração de cultos religiosos nos santuários, o povo preparava-se para as manifestações coletivas de alegria. Os ritos podiam ser sangrentos e muitas das provas eram cruéis, mas tudo o que acontecia, seja o sangue, a crueldade ou a celebração não desfiguravam o sentido festivo das reuniões. Os demais jogos, então, conhecidos na Grécia e praticados apenas pelos adultos, não se despojaram do sentido sagrado e refletiam despreocupações e alegria ou formas lúdicas de atividades. As palavras gregas que exprimem os jogos, no entanto, não envolviam as competições ou os concursos (Lyra Filho, 1973:16).

Ainda com base nas idéias desse autor, os gregos estabeleciam distinção entre a competição e o jogo: em virtude da diferença não apenas lingüística, mas também cultural. $O$ fator lúdico não predominava na competição, mas sim no jogo que era considerado simplesmente como uma distração, um brinquedo ou um divertimento. $\mathrm{O}$ impulso competitivo dos gregos evidenciou-se através de suas atividades agonísticas e os esportes revelaram-se mais tarde numa fase evoluída da cultura e como emanação dela (Lyra Filho, 1973:16).

A distinção terminológica, entretanto, não é suficiente para diferenciar a competição e o jogo. Conforme Lyra Filho, isso corresponde a uma diferença sociológica, senão mesmo psicológica e biológica. O simples enunciado dos vocábulos não cobre a gama dos significados desses termos. Lyra Filho argumenta que o idioma latino cobre o terreno do jogo com uma única palavra: ludus, de ludere, de onde deriva ludus. Ludus pode abranger os jogos infantis, a recreação, as competições, as representações teatrais e os jogos de azar. Complementa exemplificando: "competir não é brincar, recrear, distrair o tempo, entreter-se; jogar pode significar a simulação de uma atividade competitiva ou um arremedo de competição". Abordando as diferenças entre competição e jogo, o autor relaciona o primeiro vocábulo ao desafio, que envolve perigo e risco, não sendo, portanto, brinquedo ou jogo. No desafio de uma competição, há luta, e esta impõe o emprego de atributos culturais (Lyra Filho, 1973:17), o que remete às considerações iniciais do autor sobre o impulso competitivo dos gregos. Prosseguindo, o autor afirma que o jogo e o lúdico não mobilizam tais atributos, 
podendo antecipar-se à cultura. O que significa que, num sentido lúdico, o jogo não tem potenciais para criar ou desenvolver cultura.

Huizinga argumentou que o jogo como está fundamentado na cultura humana. Embora esporte não seja considerado o mesmo que jogo, o autor percebeu o jogo como um ingrediente valioso do esporte. O esporte sem o jogo torna-se separado da cultura e, então, mantém pouca importância e significado do gênero humano. Sua definição de jogo envolve três características: liberdade e espontaneidade - o jogador não pode estar forçado a jogar; particularidade - 0 jogo tem limite de tempo e lugar; e regulamentação - durante uma partida as regras são apenas inerentes ao jogo. Sua análise é relevante pois mostra o ponto de vista que o esporte é, necessariamente, uma disputa (Huizinga, 1949).

A chamada competição autêntica é marcada por peculiaridades culturais e, conforme Lyra Filho, embora não exista competição em todos os desportos, ela é a alma das atividades esportivas. Assim, existem esportes que independem de luta ou de disputa entre seus praticantes como, por exemplo, a caça e a pesca. Os esportes são competitivos quando entra em jogo a supremacia do placar, da marca, do tempo e tantos outros índices que demonstram a referida supremacia a favor de um esportista ou de um elenco de esportistas. Certos autores admitem como características gerais do jogo a tensão e a incerteza, estando sempre presente a dúvida: "Será que dará certo?" Essa expectativa verifica-se até mesmo quando se joga paciência ou quando se preenche o vazio do tempo com acrósticos, palavras cruzadas, quebra-cabeças, etc. É possível que a tensão e a incerteza atuem aí, mas não há mérito social ou cultural no resultado desse jogo ou passatempo, logo esquecido... (Lyra Filho, 1973:18). O esporte competitivo envolve constante tensão, predisposição às lutas, empenho de realização social, adestramento de aptidões e busca pelo autocontrole necessário ao êxito. A influência do esporte na vida é revelado pelo "cultivo simultâneo do instinto, da alma e do espírito, destacando fatores sócio-culturais (Lyra Filho, 1973:32). Lyra observa que "a tensão é temperada pelo autocontrole da cultura (Lyra Filho, 1973:20).

Outra questão apontada por Lyra Filho, que se relaciona ao conteúdo cultural, é o jogo como esporte, destacando que aqueles que dependem principalmente da sorte, não acrescentam nada à vida do espírito. $O$ jogo valoriza-se como esporte quando, mobilizando atributos de substância social e 
cultural, não interessa apenas aos jogadores, mas interessa à vida comunitária e envolve a humanidade (Lyra Filho, 1973:18). Sua importância consiste em elevar o tom, a intensidade da vida do indivíduo ou do grupo e considerá-lo no plano da cultura. Cada vez se torna menos sensível a identidade entre o jogo em sua forma lúdica e a competição esportiva, ou entre esta e aquela outra que se caracterizou nas primitivas lutas agonísticas da Grécia. Conforme Lyra Filho, nos tempos antigos, o maior número das competições travadas entre os gregos possuía caráter de seriedade mortal; por isto, elas não se confundiam com os jogos caracteristicamente lúdicos. Nos antigos Jogos Olímpicos havia duelos que só terminavam com a morte de um dos contendores. Eis a desfiguração cultural das competições agonísticas, extremadas até à exacerbação (Lyra Filho, 1973:19).

Ainda explorando questões relacionadas à competição, disputa, sociedade e cultura, Lyra Filho estabelece outras diferenças entre o jogo lúdico e a competição esportiva. Nessa, vale o resultado material da disputa, que se estende ao meio social e à cultura. No jogo lúdico, o êxito é efêmero e o sentimento de prazer é restrito; no esporte, o êxito ou a vitória são envolventes e persistentes, tornando-se, às vezes, crônico na lembrança do povo. $O$ sentimento de prazer é tanto maior quanto mais envolve os espectadores e se dilui na vida social. A idéia de ganhar, no jogo lúdico, vive em função do próprio jogo. Mas no esporte, ao contrário, joga-se para ganhar com a vitória a repercussão do próprio embate. Ambiciona-se ganhar com o objetivo de revelar superioridade e fazer jus à fama, ao respeito, à idolatria dos adeptos, às homenagens públicas, senão mesmo ao ingresso na História. O objetivo da competição, no esporte, não é apenas a própria vitória, mas o que possa traduzila em termos de substância sociológica e cultural. A supremacia que é comprovada com aplausos e ovações, além de manifestações de regozijo vale também para mensurar atributos humanos e sociais que se põem em cotejo no estudo universal da cultura (Lyra Filho, 1973:19-20). Conforme esse autor, a essência do jogo lúdico está ligada à idéia de algo que está em jogo, restringindo-se ao fato de acertar ou ganhar. O jogo não se transforma em espetáculo e só adquire importância cultural quando possui conteúdo desportivo (Lyra Filho, 1973). 
Standenven e De Knop estudaram a natureza do esporte com a finalidade de explorar sua diversidade para auxiliar no exame de algumas raízes das análises conceituais. Em primeiro lugar, recomendam procurar algumas idéias originais sobre conceitos de esporte, de trabalho e de jogo, desde a experiência do esporte profissional até os tipos causais de envolvimento nesse âmbito. Em segundo lugar, ressaltam um modelo de esporte que enfoque o tema como uma experiência de atividade física. Huizinga (apud Standenven; De Knop) argumentou que o jogo estava fundamentado na cultura humana. Embora esporte não tenha o mesmo significado do jogo, este é um valioso do esporte. Sem o jogo, o esporte tornou-se separado da cultura e então mantém pouca importância e significado para o gênero humano. Conforme Huizinga, a definição de jogo envolve três características: liberdade e espontaneidade - o jogador não pode estar forçado a jogar; particularidade - o jogo tem limite de tempo e lugar; e regulamentação - durante uma partida as regras são apenas aquelas inerentes ao jogo. Embora o autor se referisse aos esportes e ao atletismo, ele não se deteve em classificá-los, mas sua análise sobre jogo é relevante, pois mostra que o esporte é, necessariamente, uma atividade de disputa.

Saunders sugere que algumas mudanças do esporte na sociedade recaem em premissas de valor. Assim, uma análise do esporte e da cultura não deveria começar com julgamentos sobre a qualidade dos itens culturais, mas deveria ver cada um como satisfazendo necessidades de algumas pessoas, mesmo que desagradando outras (Saunders, 1982).

As atividades esportivas assumem caráter diverso conforme o tempo, 0 lugar e a classe social. Na Grécia antiga, a essência do culto ao corpo era o valor da época. Antes da Grécia, porém, já se praticavam esportes em outros lugares. Por exemplo, no Egito, registros artísticos mostram militares e, também outras classes, praticando esportes. Eram esportes de combate, principalmente cerimoniais e, também, atividades recreativas (Mandell, 1984).

Na Idade Média, a juventude predisposta à criatividade e ao espírito competitivo pôde ressurgir sem as marcas acerbas das lutas agonísticas que exaltavam o culto da valentia, que levava ao extermínio do oponente. Instituíase, então, a solidariedade que contribuiu para estimular o congraçamento social do povo (Lyra Filho, 1973:34). 
No Feudalismo e na Renascença, os jogos voltaram a refletir um aspecto da vida social com a restauração dos Jogos Olímpicos organizados em bases alheias à essência religiosa, militar ou agonística, o mundo começou a conhecer a cultura desportiva (Lyra Filho, 1973:26).

O esporte como existe hoje, só passou a ser conhecido no final do século XX. As competições atuais nada se pareciam com aquelas dos tempos lúdicos e agonísticos. As competições em habilidade, força e perseverança, mas ao acaso, ou sem técnica, sem regras e sem aferição de medidas culturais, não têm caráter desportivo. Elas existiram sempre, sem característica de esporte, em obediência a rituais ou como simples preenchimento de lazeres (Lyra Filho, 1973:23). Um dos fatores que contribui para explicar essas novas características do esporte no século XX é a evolução econômica que permitiu o progresso social dos povos, libertando a cultura dos preconceitos religiosos, implicando na perda das características lúdicas e agonísticas. O progresso dos esportes é tanto maior quanto mais interessa a valorização social do meio e mais intensa se faz a influência cultural do homem (Lyra Filho, 1973:36). Além desse autor, Riess (1991) e Bale (1994) preocuparam-se com as atividades esportivas nas sociedades, sua distribuição espacial e as alterações ao longo do tempo.

Na fase contemporânea, principalmente do final dos anos de 1960 até os de 1980, surgiram novas tendências no esporte e na sociedade. Os componentes do desenvolvimento, atividades, engajamento social, prazer, companhia e enriquecimento pessoal passaram a ser preocupações centrais da sociedade. Em outras palavras, uma pessoa orientada para a recreação queria participar de uma atividade ativa, observar intensamente e gostar daquilo conscientemente. $O$ esporte nas férias tornou-se, então, popular. Os principais esportes eram as caminhadas, longos percursos pela mata e natação, mas havia outros esportes também, como velejar e jogar tênis. Os clubes de férias experimentaram sucesso nesta época (Standenven; De Knop, 1990).

Ruiz destaca que os esportes evoluíram acompanhando as mudanças da sociedade e que o comportamento da população foi influenciado pelo progresso técnico, urbanização, desenvolvimento dos transportes, a evolução dos valores sociais e o comportamento individual, o imaginário ligado a um esporte, o desenvolvimento de políticas e as crises econômicas. A elite sempre foi a parcela da população responsável por induzir novos modos de vida, novas 
práticas esportivas e, conseqüentemente, levou a sociedade a mudança de valores sociais (Ruiz, 1997).

As diferentes modalidades esportivas contemporâneas variam conforme os hábitos e costumes de vida de cada povo, os países, condições climáticas e, sobretudo, a cultura e a valorização social de certas atividades.

Embora detalhes das classificações não constituam objeto desta pesquisa, convém apresentar a classificação de Bouet que, de modo simples, destaca esportes de combate, como luta, boxe, judô, esgrima; esportes com bola, como futebol, basquetebol, handebol; esportes atléticos e gíminicos, como atletismo, halterofilia, ginástica, natação; esportes da natureza, como alpinismo, canoagem; e esportes mecânicos. Esse tema, embora importante, ainda não foi completamente resolvido, sendo que uma das formas de classificar o esporte é o participante ser ativo ou passivo. A participação ativa, embora não seja a que mais prevaleça, requer o envolvimento físico do participante, ou seja, ele deve ser o protagonista do esporte. Já no esporte passivo, o participante é mero espectador da competição.

As já mencionadas características das competições, tais como desafio, perigo, risco, luta, disputa, tensão e incerteza exigem o condicionamento às regras do jogo que são normas da cultura esportiva. A fidelidade a essas regras controla instintos como agressividade, técnica e performance. Conforme Lyra Filho, sem as normas da cultura esportiva, o esporte perderia a sua própria substância e converter-se-ia em atividade agonística (Lyra Filho, 1973:26).

Para alguns autores, como Bale, todos os esportes são jogos. A diferença é que os esportes expõem destreza física e habilidade. Assim, é essencial a ênfase no físico para distinguir esportes de outros jogos (Bale, 1989:7).

Finalmente, a soma de todos esses elementos leva à conceituação de esporte. No conceito moderno, a idéia da substância cultural vem prosperando e assumindo projeção como atividade integrante à vida social, contrapondo-se à noção de simples lazer e divertimento (Lyra Filho, 1973:26).

Podemos entender, hoje, que esporte é toda a atividade que visa ao aperfeiçoamento físico e mental do homem, seja pela prática livre de exercícios, seja através de competições. Inclui, conforme Kurtzman e Zauhar, atividades 
físicas organizadas que pretendem gerar um sentido de satisfação que é renovador e vivificante (Kurtzman; Zauhar, 2000).

A partir do significado das palavras-chave deste item foi possível chegar às suas características e diferenças, o que permitiu entender o esporte através dos tempos. Esta análise possibilitou a compreensão de determinados aspectos presentes no jogo, na competição, na disputa que se aplicam ao turismo esportivo e ao automobilismo, temas presentes nesta pesquisa. 


\subsection{Estrutura e Organização do Automobilismo e das Competições}

O automobilismo, enquanto esporte, está relacionado com o turismo. Essa relação está expressa nos clubes de automobilismo, inicialmente formados em alguns países europeus como a Inglaterra, Bélgica, França, Alemanha e Itália, principalmente a partir dos primeiros anos de 1900. Uma análise da literatura pertinente a essa relação mostra que o Touring Club desempenhou importante papel na formação das primeiras associações e clubes de automobilismo, embora inicialmente estivessem dirigidos para o ciclismo.

Precocemente surgido em 1893, o Touring Club Ciclístico Italiano, basicamente apoiado na bicicleta como meio de transporte ideal por ser acessível, desenvolvia excursões, roteiros e viagens, ou seja, "Touring”. O Centro Documentazione do Touring Club Italiano relacionava o ciclismo à cartografia. Com o propósito de difundir essa atividade, foram criados meios de hospedagem nos circuitos e cartas com todas as indicações indispensáveis para os aficionados do ciclismo. O guia regional de 1896, com edições nos anos seguintes, oferecia centenas de páginas com cartas e índices, destinados a orientar os ciclistas na Itália e regiões limítrofes.

No século $X X$, com a chegada do automóvel, transporte mecânico mais rápido que a bicicleta e que tinha a vantagem de ser coletivo, o TCC - Touring Club Ciclistico Italiano passou a se denominar, a partir de 1900, TCI - Touring Club Italiano sem, contudo, renegar o turismo ciclístico (Bionda, 2003). O Touring propunha-se a contribuir para o desenvolvimento do Turismo. Sua denominação, no entanto, mudou, em 1937, para Consociazine Turística Italiana, em virtude de campanhas promovidas pelo governo contra denominações estrangeiras (Centro di Documentazione, 2000).

O ciclismo surgiu, no Brasil, como um esporte de luxo, tendo sido explorado no Velódromo de Dona Veridiana Prado, mais tarde adaptado para ser um estádio de futebol (Reis Filho, 1994:68). Até o momento, entretanto, não foram localizadas informações que pudessem fundamentar a ligação do ciclismo, no Brasil, com atividades típicas de Touring Club ou com a origem destas associações, tal como ocorreu na Itália. 
Em 1923, foi fundado, no Brasil, o Touring Club com a denominação de Sociedade Brasileira de Turismo, tendo como objetivo institucional a divulgação dos recursos turísticos do país junto à elite da sociedade. Pretendia reverter a supervalorização da Europa, idéia dominante nas elites brasileiras. A filiação aos organismos internacionais de automóveis, em 1926, conferiu à Sociedade o direito de se chamar Touring Club do Brasil. A relação com o turismo manifestouse pelas inúmeras ações que resultaram na participação em organismos públicos; na organização de viagens turísticas; na divulgação de atrativos brasileiros; na preservação da memória nacional; na realização de campanhas pela melhoria do transporte ferroviário; na realização de cruzeiros turísticos interamericanos; na melhoria das rodovias. Em 1934, foi designado como Órgão Oficial para fomento do turismo na América do Sul (Touring Clube do Brasil, 2004).

O quadro de associados se ampliou muito, principalmente a partir de 1930. Nessa época, inúmeros benefícios foram oferecidos aos filiados, muitos dos quais se mantêm, ainda hoje, nas propostas das empresas que cuidam de assistência aos proprietários de automóveis. Entre elas, assistência 24 horas, licenciamento dos veículos, emplacamento de carros, assistência nas estradas, guincho, oficinas, chaveiro, borracheiro e oficina volante, auto-socorro, entre outros (Touring Clube do Brasil, 2004).

Em 1935 foi fundado o ACESP - Automóvel Clube do Estado de São Paulo que se transformou, posteriormente, na Sociedade dos Proprietários de Veículos Automotores, embora permaneça com essa denominação. Na mesma linha de serviços do Touring Club, esta associação oferece assistência automobilística. Foi criada, entretanto, apenas para fomentar o automobilismo no Estado de São Paulo. Percebe-se que o ACESP está ligado aos serviços oferecidos aos filiados, não tendo relação direta com o Turismo (Touring Clube do Brasil, 2004).

Algumas obras publicadas por associações, como o Automóvel Clube, permitem mostrar a relação com o turismo nas primeiras décadas do desenvolvimento do automobilismo no Brasil, como é o caso do Anuário de 1928, elaborado pelo Automóvel Clube do Brasil, do Relatório do Automóvel Clube de São Paulo, de 1935, e do Auto Atlas Brasileiro do Touring Clube do Brasil, também uma publicação do clube nacional, porém em 1956. Essa última, 
especialmente, constitui um dos primeiros guias de turismo cuja base é a cartografia das principais cidades da época que representavam centros emissores de demanda. Os guias preenchem, até hoje, a necessidade de quem viaja. Particularmente numerosos são os guias dedicados aos diferentes tipos de turistas. Existem guias para aficionados ao ecoturismo, ao turismo de aventura, ao turismo de lazer, entre outros, que atendem às necessidades daqueles que viajam de automóvel.

Antigas ou modernas, as associações que congregam proprietários de automóveis têm suas raízes no Touring Club, oferecendo assistência e vantagens para os filiados, ao contrário dos grupos de aficionados por marcas e modelos, tão presentes hoje em dia. Nesse caso, a reunião de interessados acontece pela possibilidade de troca de experiências e movimenta sites e e-mail na internet.

A popularização das competições levou à necessidade da criação de organismos que respondessem pela estrutura e a organização do automobilismo. Esse esporte tem como referência um organismo internacional que é representado pela FIA - Federação Internacional de Automobilismo. No território nacional, a FIA é representada pela CBA - Confederação Brasileira de Automobilismo e, nos estados, pelas federações estaduais a ela filiadas que, por sua vez reúnem, cada uma delas, o mínimo de 5 clubes filiados. Todos os organismos voltados para o desenvolvimento do esporte seguem normas, regulamentos e estatutos que regem todas as competições que devem respeitar orientações internacionais.

A FIA estabelece a união entre seus membros, tendo em vista seis atuações: o envolvimento em todos os assuntos internacionais relacionados à mobilidade do automóvel e do esporte a motor; a promoção da liberdade da mobilidade, defendendo os direitos dos consumidores quando viajam de automóvel; o desenvolvimento do esporte a motor, legalizando, interpretando e reforçando leis comuns aplicáveis à organização e realização de eventos esportivos motorizados; o desenvolvimento de infra-estrutura e serviços para o benefício de seus indivíduos-membros quando viajam ao exterior; o exercício de jurisdição em relação às disputas de uma categoria esportiva, bem como as novas modalidades em que se verifica o aumento da participação; e a preservação e conservação de todos os documentos sobre o automobilismo 
mundial com a finalidade de preservar a sua História (FIA, 2006). Para o exercício de suas atividades, a FIA é constituída por um Instituto e uma Fundação.

O Instituto da FIA dedica-se a representar os interesses de organismos automobilísticos e usuários de automóveis, combinando a utilização das estradas e das pistas. Atua na promoção da melhoria na segurança do esporte a motor por meio do suporte e disseminação de resultados de pesquisa; no treinamento de oficiais, circuitos e pessoal de corrida em procedimentos de segurança, práticas e o uso de equipamentos; no suporte da proteção dos participantes, oficiais e membros de eventos esportivos motorizados do público ao internacional; e monitorar a segurança do esporte a motor para identificar prioridades de pesquisa e regulamentação (FIA, 2006).

A Fundação ocupa a liderança em campanhas e pesquisas de segurança rodoviária e conduz pesquisa ambiental e de mobilidade, oferecendo suporte às pesquisas de segurança do esporte a motor. Como resultado de suas relações com a Organização Mundial da Saúde, realiza trabalhos junto aos jovens pela segurança nas ruas e estradas. Junto às agendas GB e das Nações Unidas, empenha-se numa campanha internacional visando adaptar os prejuízos do tráfego rodoviário. No caso da agenda GB, uma política direcionada aos governos e autoridades locais, ao setor corporativo, ao público em geral, organizações sociais e instituições de ensino, está envolvida na implementação de uma política de mobilidade, que está baseada em planos de transporte e tráfego local e regional, sendo esta uma estratégia a ser cumprida em 2 e 4 anos (FIA, 2006).

A descrição das atividades políticas da FIA mostram o nível de envolvimento de uma organização que, inicialmente estava voltada exclusivamente para o desenvolvimento do esporte automobilístico, mas que, na atualidade, coloca-se como participante das discussões mundiais sobre a qualidade do meio ambiente em que o automóvel é considerado prejudicial. Desse modo, explicam-se as exigências da FIA quanto à atuação de seus membros pois não deve estar restrita ao setor esportivo. Conforme a FIA, os clubes ou associações de automobilismo nacional devem envolver atividades em todo o território e cobrir dois aspectos: o tráfego rodoviário, o turismo, a defesa 
dos interesses de direito dos usuários e sua segurança; e o esporte a motor, sobre o qual é outorgado o exercício do poder esportivo pela FIA (FIA, 2006).

Cabe salientar, no entanto, que junto à FIA um clube deixa de ser membro se não mais preencher todas as condições mencionadas, ou seja, as atividades dos clubes, associações e federações devem envolver todo o território nacional e cobrir o tráfego rodoviário, turismo ou camping (FIA, 2006). No Brasil, por outro lado, a CBA se detém, claramente através de seu estatuto, ao setor esportivo. Em relação aos interesses de usuários dos automóveis foi fundada, em 1994, a AAB - Associação Automobilística do Brasil cuja proposta é desenvolver trabalhos em defesa dos interesses e direitos dos automobilistas. Quanto ao turismo sua relação com o automobilismo não são contemplados por nenhum organismo nacional.

Em relação aos campeonatos realizados sob tutela da FIA, a Fórmula 1 é uma das 25 competições, que totalizam 195 eventos no ano de 2007. Além da Fórmula 1 em São Paulo, outra modalidade tem etapa no Brasil. É o caso do World Touring Car Championship, realizado em Curitiba, no Paraná. Em 2007, no Autódromo de Interlagos, a prova Mil Milhas Brasileiras foi integrada como a prova de encerramento do campeonato Le Mans Series e a visita de representantes da FIA ao Rally dos Sertões tem em vista homologar uma das etapas para a realização de um campeonato internacional dessa categoria.

Filiada à FIA, a CBA representa a entidade máxima federal de administração do esporte automobilístico e foi fundada em 7 de Setembro de 1961, pelas Federações Paulista, Gaúcha, Mineira, Paranaense e Carioca de Automobilismo, Automóvel Clube de Brasília e de Blumenau. Caracteriza-se por ser uma sociedade civil de caráter social, técnico desportivo, com sede na cidade do Rio de Janeiro (RJ) e foi instituída pelo Decreto 51.857, de 20.03.63; retificada pelo Decreto 54.387, de 07.10.64; e referendada pela Lei 5.108 de 21.09.66 (que instituiu o Código Nacional de Trânsito).

De acordo com o estatuto da CBA, de 2005, os objetivos institucionais estão direcionados para vários aspectos da área esportiva. O turismo é contemplado apenas no que se refere à organização dos eventos. Dentre os objetivos da CBA estão: a coordenação do complexo técnico-desportivo do automobilismo brasileiro, regulado por normas nacionais e internacionais e pelas regras de prática desportiva; o exercício do poder desportivo automobilístico 
Nacional e Internacional; a direção, difusão e incentivo, no país, todas as modalidades desportivas automobilísticas e, desde que credenciada, o desenvolvimento das atividades ligadas ao turismo, trânsito e transportes, nos moldes regulamentados internacionalmente; a promoção, autorização e fiscalização da realização de campeonatos e torneios desportivos nacionais e internacionais; o estímulo máximo na publicação e no incremento do desporto amador, assim como na disciplina da organização e da prática das modalidades profissionais ou mistas, sujeitos à sua direção; o cumprimento dos mandamentos originários dos organismos Internacionais, assim como dos atos legalmente expedidos pelos órgãos ou pelas autoridades que integram os poderes públicos; a expedição, conforme a competência, de códigos, normas, regulamentos, regimentos, avisos, portarias, circulares, instruções ou outros quaisquer atos necessários a organização, ao funcionamento e a disciplina do automobilismo, observada a legislação desportiva vigente; o julgamento dos responsáveis por inobservância de qualquer dos mandamentos compreendidos na alínea anterior, de acordo com a legislação disciplinar vigente; a resolução a respeito dos praticantes do desporto; a representação e defesa, perante os poderes públicos, dos interesses legítimos do automobilismo nacional; a decisão a respeito da participação de entidades e concorrentes em provas desportivas fora da respectiva jurisdição regional, inclusive no exterior; a representação do automobilismo em qualquer atividade de cunho internacional, com poderes para celebrar acordos, contratos e convênios, assim como autorizar, orientar, coordenar e fiscalizar as atividades internacionais de suas filiadas; e, finalmente, o exercício dos poderes, atividades e deveres atribuídos por lei, decretos, portarias e deliberações das autoridades federais (CBA, 2006).

A CBA é constituída pelas entidades de administração do esporte automobilístico estadual, que são designadas como Federações e a ela são filiadas. As federações, por sua vez, possuem clubes, associações ou ligas também filiadas, de acordo com a sua jurisdição, cada qual incumbida de atividades automobilísticas, respeitando os princípios esportivos estabelecidos pelos órgãos dos quais são subordinadas. A CBA emite, anualmente, alvará de funcionamento dos clubes. 


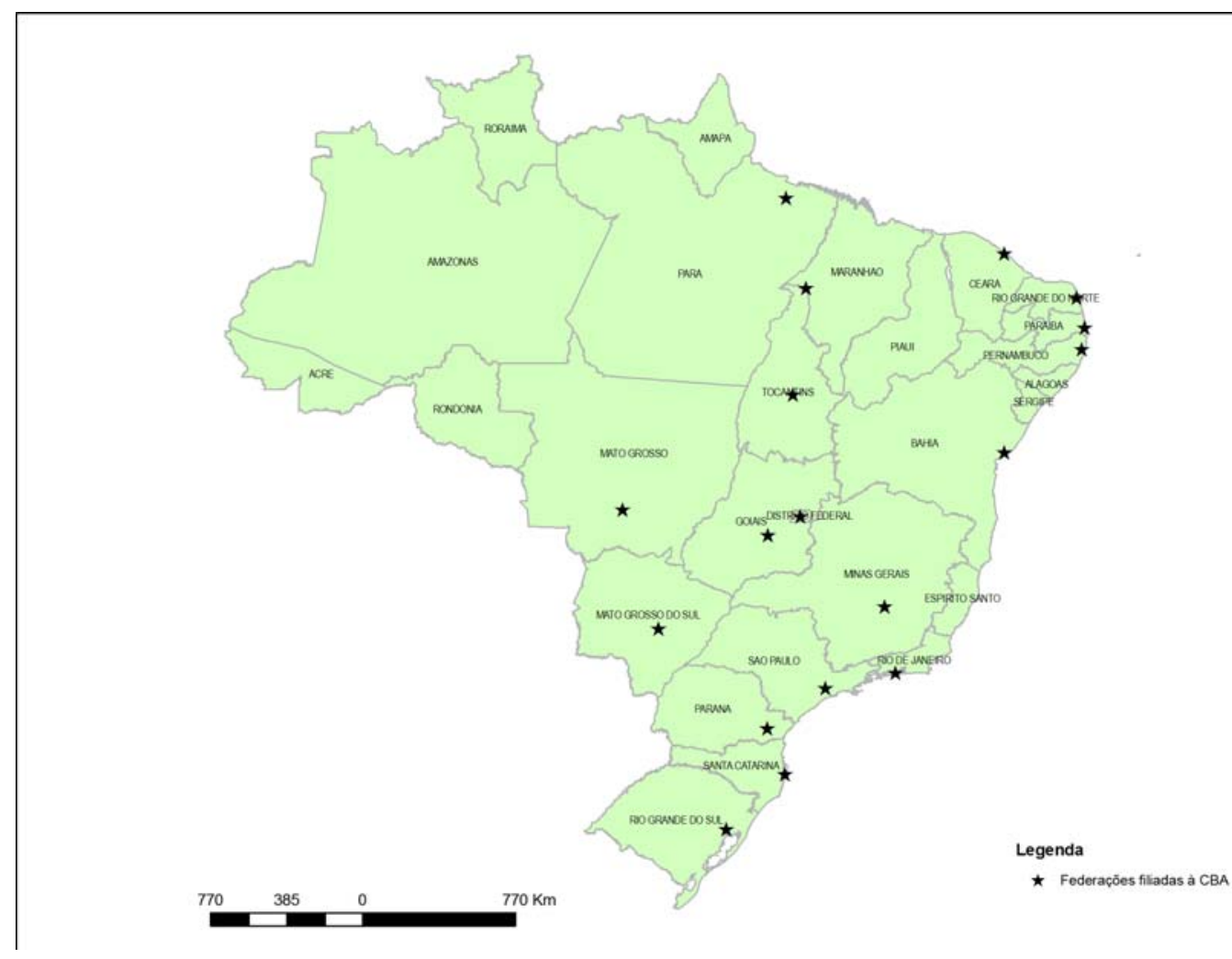

Figura 1 - Federações de Automobilismo filiadas à CBA.

Estão filiadas, atualmente, 18 federações (Figura 1), distribuídas pelo território brasileiro. Com exceção dos estados do Espírito Santo, Sergipe, Alagoas, Piauí, Amapá, Roraima, Amazonas, Rondônia e Acre, todos os outros têm representatividade na CBA. Para a constituição de uma Federação, que representa a jurisdição do estado, deve existir o mínimo de 3 clubes de automobilismo de competição, legalmente constituídos. Estes, em conjunto, devem ter, no mínimo, 50 pilotos inscritos. Cada Federação, em seu processo de filiação à CBA, deve comprovar que no estado há a prática de, pelo menos, 3 diferentes modalidades de automobilismo de competição. No estado em que não há as condições mínimas para a criação de uma federação, o clube pode se filiar diretamente à $\mathrm{CBA}$, mas não tem direito a voto. Há um período um período de filiação provisória, por 4 anos, e só então a filiação torna-se de caráter definitivo. A cada ano, todos organismos, sejam federações ou clubes filiados, devem realizar campeonatos, provas ou torneios de pelo menos uma das diversas modalidades de automobilismo promovidos ou reconhecidos pela CBA. Apenas dessa forma, os filiados passam a ter todos os direitos e obrigações constantes do estatuto. Para a obtenção do Alvará de Funcionamento, os filiados devem estar em dia com suas responsabilidades junto a CBA (CBA, 2005). 
Esta descrição mostra que os autódromos e circuitos supervisionados pelo setor esportivo estão estruturados para a realização de competições esportivas. Eventos sem respaldo dos órgãos do setor esportivo representam ilegalidade, uma vez que não há quem se responsabiliza pela segurança de todos os participantes de uma competição. Um aviso no site de uma federação alertava sobre a existência de grupos independentes que procuravam as prefeituras apresentando propostas de realização de eventos esportivos.

$\mathrm{Na}$ CBA existe uma comissão especificamente designada para a fiscalização dos autódromos e circuitos, incluindo a construção, o planejamento, a administração, a conservação, a qualificação, o funcionamento e o registro de autódromos, circuitos e pistas permanentes. Portanto, todos os locais onde devem estar realizadas provas esportivas estão registrados e homologados pela CBA. Nas pistas estabelecidas em caráter transitório, normalmente em vias públicas, apenas são realizadas provas automobilísticas e incluídas no calendário oficial, depois de previamente submetidas à apreciação da CBA. Nas cidades em que já existe circuito permanente homologado, é vetado qualquer competição em circuitos alternativos, como os circuitos de rua, quando realizada em vias públicas, fechadas ao tráfego de veículos ou não (CBA, 2006).

No meio esportivo, conforme a CBA, o evento é aquele que reúne concorrentes ou oficiais de competição, compreendendo uma ou várias competições ou tentativas de recordes. Uma competição, prova ou bateria ou manifestação esportiva é toda corrida, tentativa individual, tentativa de recorde, concurso de resistência ou regularidade, rally ou concentração turística na qual um automóvel tome parte, com a finalidade de competir (CBA, 2006).

A competição, segundo os parâmetros da CBA, se inicia no ato da inscrição do piloto e se encerra na homologação dos documentos da prova pela CBA ou federações após serem julgadas todas as pendências esportivas, técnicas e jurídicas.

A princípio, uma competição possui cinco abrangências de acordo com a divisão político-administrativa conjugada ao poder esportivo competente (confederação, federação ou clubes): competição nacional, interestadual, estadual, intermunicipal e municipal. Diferencia-se, no entanto, a competição reservada e a fechada. A competição reservada diz respeito à competição em 
que é permitida somente a participação de concorrentes e pilotos portadores da Cédula Desportiva da CBA, com regulamentação específica, organizada ou supervisionada por uma federação de automobilismo. A competição fechada é aquela em que a participação de concorrentes e pilotos, portadores da Cédula Desportiva da CBA ou correspondente de entidade reconhecida pela FIA, é admitida através de convite da própria entidade ou da federação (CBA, 2006).

Em qualquer competição são utilizados, usualmente, termos como prova, bateria, largada, grid e pit lane. Conforme a CBA, a prova é a competição integrante de um evento automobilístico, com várias atividades a ele relacionadas, ou uma realização isolada, podendo se constituir numa etapa de campeonato ou torneio, ou numa competição isolada. A bateria é parte de uma determinada prova, com um número de voltas ou tempo previamente regulamentado, podendo também se constituir em uma etapa de um campeonato ou torneio. Os demais termos, largada, grid e pit lane são assim definidos: largada, o exato momento em que é dada a ordem de partida para um concorrente, isolado ou vários, de um grid; grid, a ordem oficial de largada dos veículos para uma corrida, refere-se, portanto, à posição dos pilotos antes do início da prova; e pit lane, a linha de largada ou chegada, a linha de controle inicial e final, com ou sem cronometragem (CBA, 2006).

As convenções visam de proteger os pilotos de sabotagens. Uma delas refere-se ao "parque fechado", ou seja, um espaço obrigatório em todos os circuitos que é destinado a todos os concorrentes para ali deixarem o veículo a ser utilizado numa prova. Adotados em comum acordo, alguns procedimentos são adotados para garantir a integridade dos veículos, sendo eles: o acesso ao seu interior só é permitido para os oficiais de competição designados para sua supervisão; quaisquer ajustes, reparos, ou checagens são proibidos, a não ser em casos especiais, devidamente autorizados pelo comissário técnico; nenhum veículo poderá ser retirado do Parque Fechado sem autorização expressa do Comissário Técnico; e a não apresentação do veículo no horário previsto no regulamento particular da prova, implica em penalidade ao piloto nos treinos, baterias, ou provas (CBA, 2006).

No início de uma competição, o momento denominado briefing refere-se à uma reunião entre o oficial do diretor de prova, comissários esportivos e pilotos, destinada a informar a todos quanto aos procedimentos gerais de uma 
corrida. Essas informações têm valor de adendos ao regulamento da competição (CBA).

Algumas considerações sobre a formação do grid de largada: é obedecida a seqüência dos melhores tempos de provas de tomada de tempo, sendo a posição inicial denominada poli-position; logo após o conjunto de pilotos e veículos são alinhados o conjunto pilotos e veículos que tiverem sido punidos em razão de alguma irregularidade; e, finalmente, são alinhados o conjunto piloto e veículo que não tiverem se apresentado para a tomada de tempo, sendo posicionados de acordo com o resultado de sorteio previamente realizado (CBA, 2006).

Durante a realização de uma prova, diversos profissionais do meio esportivo possuem posicionamento e funções específicas. Todas as provas necessitam de: um diretor de prova; comissários desportivos, às vezes assistidos por adjuntos; secretário; cronometristas; comissários técnicos; vistoriadores; comissários de abastecimento; comissários de pista; comissários de box; sinalizadores; juízes de largada; juízes de chegada; controladores; e largadores (CBA, 2006).

A supervisão da pista destina-se a garantir as condições de segurança durante o desenrolar de toda a prova, sendo responsável ainda pelo serviço de intervenção, e pelo fornecimento do pessoal e material especializado necessário. Todas essas operações deverão estar sob o controle final do diretor de prova, durante todo o evento. Recomenda-se que o diretor de prova designe um diretor adjunto para organizar e dirigir a supervisão da pista e os serviços de intervenção. Para cada prova, um plano conjunto é estabelecido para controlar as operações. Esse plano consiste de: um posto de controle de corrida; tantos postos de supervisão quantos forem necessários; serviços médicos e de combate a incêndio, com os veículos necessários; medidas de segurança destinadas à proteção dos concorrentes, oficiais e público em geral (CBA, 2006).

O posto de direção de prova deve estar equipado com rádio para comunicação com os veículos e postos de supervisão na pista; rádio comunicador ligado com os oficiais de competição que estiverem na pista; microfone ligado ao sistema de som, para comunicação com os boxes; televisor e um gravador de vídeo; conjunto de bandeiras de sinalização; placa de sinalização para os pilotos, com uma quantidade de números suficiente para 
identificá-los quando for necessário apresentar-lhes uma sinalização específica (CBA, 2006).

Antes da largada da prova ou da reabertura do circuito, é dever do diretor de prova ou do seu adjunto, realizar o fechamento da pista, para se assegurar de que todo o sistema de supervisão esteja em pleno funcionamento. Os postos, localizados ao lado da pista, devem prever uma área suficiente para que os oficiais possam se abrigar com seu equipamento de trabalho, e se proteger dos veículos de competição. O número e a localização dos postos serão determinados em função das características de cada circuito. A distância entre dois postos não deve exceder a 500 metros, e a visão entre eles deve ser completa.

O oficial responsável pelo posto de sinalização orienta os demais oficiais para: advertir os pilotos por meio de sinalização, de todos os perigos ou dificuldades que eles não possam prever; informar a direção de prova, de todo incidente que venha a ocorrer nos limites de intervenção de seu posto, e propor a ação adequada de serviços de urgência, se necessário; assegurar-se de que a corrida se desenvolva de uma maneira correta do ponto de vista desportivo, e relatar à direção de prova todo comportamento perigoso ou anti-desportivo; manter seu setor da pista limpo e livre de obstáculos, principalmente no que se refere a eventuais poças de óleo.

No que se refere às características fundamentais do desafio, conforme Haywood e Kew (1994), que inclui o desafio ambiental e interpessoal, no automobilismo isso se aplica à situação do piloto e à constituição do circuito.

O próprio ar e sua gravidade representam o desafio ambiental preliminar já que o piloto tem que transpor a inércia. Vencer a inércia para percorrer um circuito é o objetivo inicial do desafio. Os movimentos de um piloto dentro de seu cockpit parecem ser relativamente simples, porém as características do circuito exigem habilidades psicomotoras e plano estratégico para controlar o carro no contorno das curvas e para realizar ultrapassagens e paradas nos boxes para manutenção. Logo, o desafio interpessoal refere-se à participação de concorrentes.

Conforme definido pela CBA, o circuito é constituído por pistas permanentes, notadamente aquelas que comportem curvas e retas, que podem 
ser percorridas em grande velocidade. Deve-se esclarecer, contudo, os termos pista, percurso e trecho. Desse modo, considerando as definições esportivas, entende-se por: pista, o percurso utilizado de forma permanente ou temporária, para competições e recordes; percurso, o trajeto a ser seguido pelo piloto e concorrentes; e trecho, a distância percorrida entre o início e o término do percurso ou entre a largada e a chegada (CBA, 2006).

Como estabelece a CBA, o piloto é a pessoa física que conduz um veículo em uma competição e concorrente é toda pessoa física ou jurídica que participa de uma competição. Ambos devem, obrigatoriamente, portar o documento exigido pela CBA (CBA, 2006).

As condições impostas ao desafio, conforme Haywood e Kew (1994), referem-se ao equipamento utilizado, às condições da competição, às regras e às convenções. No automobilismo, o veículo de propulsão mecânica é o equipamento manipulado pelo piloto. Segundo a CBA, o veículo terrestre é o aparelho movido por seus próprios meios, que se desloca de forma constante, apoiado realmente sobre a superfície terrestre, seja direta ou indiretamente por meio mecânico, e cuja propulsão e direção sejam constantes e inteiramente controladas por algo ou alguém a bordo (CBA, 2006).

Dessa forma, não é qualquer pessoa que pode participar de uma competição. Nessa, a comprovação de graduado em pilotagem é uma exigência tanto para as provas destinadas aos amadores como aos profissionais de automobilismo, o que é fornecido pelo aprendizado progressivo por meio de níveis distintos. Para os jovens com até 16 anos ou para adultos, os cursos variam de acordo com o grau de aperfeiçoamento alcançado e a especialidade definida, sendo que as possibilidades são: piloto de kart, de arrancada, de velocidade, de rally, de velocidade de terra ou de teste. A experiência continuada da prática esportiva automobilística também é uma condição para a inscrição em qualquer evento, inclusive para os rallyes. Os participantes sem nenhuma experiência em provas anteriores também são contemplados, porém em categorias e provas distintas e, normalmente, são classificados como: categoria turismo, estreantes, amadores e iniciantes. Fazem parte dessas categorias, inclusive, aqueles que já participaram de eventos em categoria superior mas que, nos últimos 5 anos ou outro período estipulado pela organização do evento, não concorreram em nenhuma prova. Outras categorias diferenciam, então, 
aqueles mais experientes, como é o caso das categorias sênior ou veteranos, e aqueles com mais prestígio e notoriedade, como é a máster ou graduados.

Numa competição, todos os pilotos estão, portanto, em condições de igualdade e têm o mesmo objetivo que é realizar o melhor tempo possível. A competição entre oponentes é própria do automobilismo e é uma questão de interesse comum. O desafio principal da competição no automobilismo, em que não há combate ou luta entre adversários, é uma disputa pela melhor colocação. O que se almeja numa prova é, portanto, o recorde, que é definido pela CBA como o resultado máximo obtido nas condições determinadas pelos regulamentos; um recorde pode ser mundial, nacional, interestadual, estadual, intermunicipal ou municipal (CBA, 2006).

Cabe esclarecer que mesmo os integrantes de uma equipe são responsáveis juridicamente. Uma equipe, conforme a CBA, é a pessoa jurídica que possui em seus quadros um ou mais pilotos e um ou mais veículos regularmente inscritos em uma ou mais modalidades. Para a equipe também é concedida uma licença, ou seja, o certificado de registro equivalente à sua atuação, seja piloto, concorrente, oficial de competição, equipe ou time, organizador, entre outros. Todos os envolvidos, portanto, que possuem a intenção de participar ou tomar parte, sob qualquer pretexto, em competições ou tentativas de recorde, são nomeados e caracterizados esportivamente.

As mais novas categorias do automobilismo, embora menos divulgadas, porém com demanda de participantes, têm sua competição organizada da seguinte maneira: destinadas a estudantes, a categoria escola e o rally universitário. A categoria escola é a competição realizada em circuitos, cujos veículos são do tipo monoposto, com construção regulamentada especificamente, sem nenhum artifício que provoque efeito aerodinâmico, com pneus do tipo radial, sendo proibida a utilização de pneus do tipo slick (CBA. 2006). Essas competições, que reúnem os protótipos construídos por instituições de ensino superior, são muito populares entre os futuros engenheiros. Já no rally universitário, o veículo não é o determinante, mas, sim, a condição do participante, sendo uma categoria destinada exclusivamente aos estudantes. A prova é realizada em estradas abertas à circulação normal, com trechos de médias impostas, e sempre em obediência ao Código Brasileiro de Trânsito, além de devidamente autorizada pelos poderes competentes. 
Entre as três categorias restantes para o rally (turístico, de regularidade e de velocidade), a condição de participação do piloto também é determinante. As duas primeiras categorias são provas realizadas em estradas abertas à circulação normal, com trechos de médias impostas e sempre em obediência ao Código Brasileiro de Trânsito. O primeiro, no entanto, distingue-se como sendo turístico por ter como objetivo o encontro num local determinado previamente. $A$ última categoria é a competição de velocidade livre em estrada, rua ou circuito, que se desenrola sobre trechos previamente determinados e totalmente fechados à circulação normal, sempre com a autorização dos poderes competentes (CBA, 2006).

A estrutura e a organização do automobilismo e das competições esportivas prevê que os participantes sigam determinadas regras estabelecidas pelos organismos internacionais e nacionais que controlam essa atividade. Assim, esportistas devem estar devidamente credenciados e legalizados perante suas associações. Da mesma forma, os autódromos, espaços onde se realizam as competições devem seguir as orientações dos setores competentes.

$\mathrm{Na}$ busca de informações sobre a estrutura e organização do automobilismo e das competições, verificou-se que não só o touring clube como também os clubes de automobilismo, as associações e outros organismos têm relação com as modalidades praticadas nesse esporte. Dessas, foram selecionadas o antigomobilismo e o fora-de-estrada ou off-road pela pertinência que apresentam com a estrutura e a organização do automobilismo, que serão analisadas a seguir. 


\subsection{Antigomobilismo: a valorização da cultura}

As manifestações de antigomobilismo são organizadas por clubes locais e a essência dessa forma de lazer está pautada na história do automóvel que reflete o desenvolvimento econômico e social do país. O antigomobilismo tem conquistado espaço, o que pode ser avaliado pelo aumento do número de revistas especializadas, de lojas e oficinas voltadas para esse segmento e, principalmente, pela valorização de acervos e coleções, públicas e particulares, e pela quantidade de eventos relacionados ao tema.

Revistas especializadas e inúmeros sites dedicam-se a atender as mais diversas necessidades dos antigomobilistas, incluindo, não apenas a compra e venda de veículos, de peças e de equipamentos, mas, sobretudo, a oferta de informações referentes aos procedimentos técnicos para a manutenção de motores, da parte elétrica e outros.

Os especialistas mostram que o número de colecionadores tem crescido em relação ao limitado volume de automóveis, resultando na valorização dos veículos antigos. Esses automóveis ganham valorização à medida que atendem quesitos como raridade e exclusividade, ou seja, aqueles que foram produzidos em escala limitada ou que desempenharam um papel histórico por ter sido conduzido ou servido a alguma personalidade. Veículo original é considerado aquele que mantém as características construtivas, de decoração e realiza operações idênticas ao momento em que foi produzido. Apenas é permitido agregar acessórios disponíveis à época. A preferência por um veículo nacional e a insistência em encontrar componentes originais são outros critérios de escolha. Há, normalmente, três opções no mercado: o veículo já restaurado, aquele em fase de restauração e as relíquias que, em geral, são encontradas em propriedades rurais e tem seu uso subestimado ao extremo, como é o caso de virarem galinheiro. Depois de encontrar o favorito, uma primeira providência será torná-lo operacional, a começar pela documentação (Automóveis Antigos, 2006).

Além do ritual do espécime perfeito e adequado, outras experiências dos antigomobilistas são fomentadas, como a participação em eventos onde estabelecem contatos com aficionados com os quais discutem o que mais se mais valoriza no mercado. 
Colecionadores mais conscientes procuram preservar a originalidade e perseguem a autenticidade de uma época. Junto aos colecionadores, os veículos restaurados têm significado particular porque possuem valor sentimental, que não pode ser quantificado.

"A prática do antigomobilismo está nitidamente associada à atitude cultural de preservar a história. Seus adeptos vêem os veículos antigos não como objeto único, mas como integrantes de um cenário sócio-econômico e tecnológico de uma época. São em número crescente, agindo sozinhos ou em clubes e associações. Entendem os antigomobilistas que um veículo antigo restaurado, apto a andar confiavelmente, ostentando todos os brilhos quando do dia de sua fabricação, constitui-se num retrato vivo da história, e não apenas em mais uma agregação harmônica de latas e parafusos. Para irritar um antigomobilista diga-Ihe que seu carro ficou bem "reformado". A palavra chave é restaurado." (Costa, 2006).

Uma preocupação dos antigomobilistas, como explicou um colunista da revista Automóveis Antigos, é que nenhuma montadora lembrou de preservar os primeiros automóveis fabricados no Brasil, ao contrário de suas matrizes que se preocupam em preservar os modelos produzidos e guardam, cuidadosamente, o seu passado em museus e showrooms. "Mostrar, às gerações futuras, o desenvolvimento da indústria automobilística só pode acontecer desta maneira" (Automóveis Antigos, 2006). A cultura e a história presentes nos acervos automobilísticos dos museus normalmente referem-se aos bens de pessoas ilustres, com elevado poder aquisitivo. O Museu Histórico Nacional, no Rio de Janeiro, e o Museu Paulista no Ipiranga, em São Paulo, têm em exposição veículos de transporte terrestre, tanto de tração humana como animal, utilizados na época da corte portuguesa. Entre eles, cadeirinhas, berlindas e carruagens, além de automóveis dos primeiros cinqüenta anos de 1900.

O Museu da Tecnologia da ULBRA - Universidade Luterana do Brasil, localizado na cidade de Canoas, no Rio Grande do Sul, destaca-se por abrigar 270 veículos entre carros de passeio, utilitários e motos, em uma área de 9.346 $\mathrm{m}^{2}$. Uma outra área adjacente, de $6 \mathrm{mil} \mathrm{m}^{2}$, foi reservada para veículos e oficinas de restauro. Cerca de 350 unidades de veículos, das mais variadas marcas e modelos, estão sendo restaurados, o que evidencia a valorização do automóvel pela sociedade (ULBRA, 2007). 
O Museu do Automóvel, em Brasília, procura mostrar a relação da história dos veículos, exibindo fases do desenvolvimento social, tendências e modismos, momentos econômicos e padrão tecnológico de várias épocas, além de integrar um centro cultural denominado Memória dos Transportes. De iniciativa privada, seus idealizadores pretendem "despertar a consciência das pessoas sobre a identificação e preservação de marcos da história do desenvolvimento do país, instigando a geração de novos antigomobilistas" (Museu do Automóvel, 2007).

A preservação de elementos da indústria automotiva nacional constitui a proposta do Museu do Automóvel de São Paulo que foi inaugurado, recentemente, em 1999. A iniciativa, de caráter particular, tem uma coleção de 90 automóveis produzidos entre 1910 a 1950 e ocupa um galpão de mil metros quadrados, destinado à exposição fixa e, também, rotativa (Museu do Automóvel de São Paulo, 2007) Nesse aspecto, vale esclarecer que a oferta de automóveis antigos atende, atualmente, às necessidades de produtores de filmes e novelas, além de organizadores de festas.

A única iniciativa relacionada a fábricas de automóveis é da empresa Wolkswagen, sendo que o Museu Anhangüera do Automóvel é virtual, utilizandose da internet para disponibilizar um conteúdo técnico sobre todos os carros produzidos.

Grupos inusitados aparecem no automobilismo, como é o caso dos aficionados por ônibus. Um portal voltado para os usuários do transporte coletivo, além de oferecer serviços e informações, realizou o $1^{\circ}$. Encontro Brasileiro do ônibus, em 2004, apresentando clássicos de várias empresas do setor, uma iniciativa que estimulou o desejo de implantar um museu específico.

Os clubes de antigomobilismo representam uma forma de sociabilização, envolvendo os filiados em demonstrações espontâneas do prazer de ser proprietário de um automóvel. Para regularização junto ao DETRAN Departamento Nacional de Trânsito, uma placa preta para o licenciamento que é exigida aos veículos antigos com, pelo menos, 30 anos. A legislação brasileira de trânsito apresenta, portanto, diferenciação para o automóvel antigo de coleção. Para ser considerado como tal, o veículo deve preencher os seguintes requisitos: ter sido fabricado há mais de 30 anos; conservar as características originais de fabricação; integrar uma coleção; e apresentar o Certificado de 
Originalidade reconhecido pelo DENATRAN - Departamento Nacional de Trânsito. Esse departamento tem a atribuição de fornecer emplacamento distinto com a expedição da placa preta. Além dessa legislação, o governo brasileiro impediu, através do DECAX - Departamento de Operações do Comércio Exterior, a venda ao exterior de carros antigos que eram considerados como sucatas. Desse modo, tanto os veículos estrangeiros como os nacionais permanecem no país como objeto de interesse histórico-cultural. O automóvel licenciado como Veículo de Coleção torna-se, então, personalizado, sendo dispensado do uso de equipamentos de segurança, que são obrigatórios para aqueles fabricados posteriormente, e da Inspeção de Segurança Veicular (FBVA, 2007).

A forma de diferenciar veículos antigos dos demais legitima a atuação da FBVA - Federação Brasileira de Veículos Antigos, uma entidade que promove a conservação do automóvel antigo e que divulga o antigomobilismo como uma atividade cultural. Assim como no automobilismo, o antigomobilismo também possui jurisdição internacional, nacional, estadual ou municipal.

A filiação, desde 1999, à FIVA - Federation Internationale de Vehicules Anciens, com sede em Paris, permitiu que a entidade brasileira recebesse o título de ANF - Autoridade Nacional FIVA e, dessa forma, tornou-se responsável pela emissão do Passaporte FIVA (FIVA I.D.), um certificado exigido para que um automóvel brasileiro participe de provas esportivas e de exposições, seja no Brasil ou no exterior (FIVA, 2007).

A FIVA foi fundada em 1966 e é responsável pela formulação da idéia central de um grupo de organizações que representavam os interesses de entusiastas do veículo histórico provenientes de diferentes países. O organismo internacional colocou-se na promoção e orientação dos interesses de um movimento de proprietários de veículos históricos presente em vários países. Atualmente, há 75 organizações-membros em mais de 50 países, sendo 30 na Europa, 10 na América e 12 no resto do mundo, o que representa mais de 750 mil entusiastas de veículos históricos (FIVA, 2007).

Para solucionar problemas ocasionados pela circulação de veículos antigos junto à modernidade das cidades, o primeiro objetivo da FIVA foi, justamente, estimular o uso seguro de carros antigos com a idade mínima de 25 anos. 
A FIVA realiza pesquisas e presta assessoria, contando com uma comissão legislativa. A ela compete: realizar estudos sobre o movimento dos veículos históricos; elaborar regulamentos de monitoramento e assessoria a nível nacional e internacional; manter relações com empreendedores e políticos, como a Comissão Européia, membros do Parlamento Europeu, membros de estado e da sociedade civil; e apresentar pareceres, políticas e soluções para tomada de decisões (FIVA, 2006).

A FIVA, fundada em 1987, se empenha no reconhecimento do significado cultural dos veículos históricos pelas autoridades legais e políticas, além de outros organismos. Esse reconhecimento pela importância cultural dos veículos históricos se amplia na atuação de todos os seus membros. São constantemente avaliadas as leis ou regulamentações que podem representar um risco e prejudicar a conservação ou a utilização dos veículos históricos (FIVA, 2007).

Dentre os objetivos dessa organização internacional, estão, portanto, coordenar as atividades dos clubes associados e do calendário nacional de eventos; fornecer orientação para a formação de novos clubes; e manter a representatividade junto às autoridades federais, estaduais e municipais, numa tentativa de colaborar em todos os assuntos que dizem respeito ao automóvel antigo, como, por exemplo, pleitear benefícios legais e proteção para as atividades do setor (FIVA, 2007).

Entendendo que a preservação de veículos históricos é parte importante do patrimônio industrial, a FIVA promove a catalogação dos veículos históricos, emitindo o passaporte FIVA através de uma comissão técnica. Relações com a UNESCO e com Comissão Européia também fazem parte da sua atuação visando a aceitação dos veículos históricos como representantes do patrimônio industrial (FIVA, 2007).

O intercâmbio com a FIA - Fédération Internationale de l'Automobile tem o intuito de envolver os carros históricos em outras áreas esportivas. A FIM Fédération Internationale Motorcyliste tem se apoiado no exemplo da FIVA já que essas conquistas também se aplicam às motocicletas (FIVA 2007).

Embora com atuações distintas, a FIVA e a FIA, no entanto, têm interesses convergentes no que diz respeito à valorização dos carros antigos. As 
entidades cooperam entre si para defender, de forma eficaz, a livre circulação dos veículos históricos, dirigindo seus esforços para aumentar a segurança. As manifestações de natureza esportiva referentes a automóveis históricos são de competência da FIA e de seus membros. As manifestações de regularidade não esportivas utilizam-se dos regulamentos dos dois organismos. As manifestações turístico-históricas são de competência exclusiva da FIVA, e quando se organizam sob tutela da FIA, deve-se respeitar, também, o Código Internacional de Manifestações da FIVA. No que se refere mais particularmente aos rallyes históricos de regularidade ressalta-se a importância de respeitar os documentos oficiais sobre o movimento histórico para que e a segurança das manifestações não seja prejudicada (FIVA, 2007).

Criado, em 2002, pela FIA, o Heritage Cetificate está dirigido aos automóveis esportivos antigos que são avaliados quanto a sua originalidade. Esse documento torna-se essencial para todos os proprietários, especialmente colecionadores. O objetivo é confirmar a legitimidade de um veículo, analisandoo em três aspectos: época de construção do veículo, continuidade ou não de sua fabricação e se foi submetido a tributação e exame para os dois critérios anteriores. O certificado não é um troféu ou prêmio, é mais uma medida para proteger o patrimônio automotivo. É preciso ter certeza de que o veículo é genuíno, e não uma reprodução. O carro valorado pelo seu valor emocional e de mercado pode conseguir essa certificação que representa a garantia desses dois atributos. Também para a FIA, os veículos históricos e clássicos são importantes pois constituem o patrimônio da motorização e do esporte a motor (FIA, 2007).

As iniciativas descritas mostram a variedade de temas e ações relacionados à continuidade do uso dos veículos antigos. Percebe-se que a prática do antigomobilismo não se restringe às exibições estáticas, que atraem a curiosidade das pessoas de várias camadas sociais, mas envolvem também assuntos contemporâneos.

A FBVA, em 2002, constituiu o bloco Sul-americano, envolvendo relações com os países da Colômbia, Equador, Paraguai, Peru, Uruguai, além da Argentina, que já possui dois clubes filiados. As ações práticas envolvidas nesse intercâmbio podem ser verificadas através da participação dos aficionados em eventos sul-americanos 
No Brasil, a princípio, as atividades estão relacionadas à legalização de veículos, incluindo importação de automóveis ou de peças, e ao emplacamento especial que é atribuído aos órgãos de competência governamental.

Ainda com referência ao organismo internacional, observam-se aspectos relacionados com a organização, direção e gestão dos eventos realizados sob competência da FIVA. Segundo suas definições, uma manifestação histórica é aquela destinada aos veículos com o específico limite de idade, que utilizam as vias públicas num itinerário administrado pelos organizadores. Existem 4 tipos de manifestações históricas: regularidade, longa distância, histórico-turística e concurso de elegância (FIVA, 2007).

A manifestação histórica de regularidade é uma manifestação de caráter turístico no qual a velocidade mais elevada ou o melhor tempo não são fatores determinantes, e para a qual é conveniente estipular velocidades médias de $50 \mathrm{Km} / \mathrm{h}$ ou inferiores. A manifestação histórica de longa distância segue a mesma definição anterior, alterando-se apenas a distância a ser percorrida, as condições ou a dificuldade de certas regiões. A manifestação histórico-turística não é competitiva e em sua classificação está completamente ausente o fator tempo. No concurso de elegância, a qualidade dos veículos é julgada segundo as normas estabelecidas pelos organizadores, sendo duas as categorias: manifestações internacionais e outras organizadas fora do país de origem do organizador; e aquelas que são regidas por uma Autoridade Nacional, ou um dos membros (FIVA, 2007).

Em relação às condições dos veículos, é permitida a participação de veículos históricos que preencham as especificações da época de sua fabricação, excluindo aqueles que utilizaram novas tecnologias. $O$ regulamento de um evento de antigomobilismo deve fomentar a autenticidade dos veículos participantes e, desse modo, os prêmios especiais de um concurso de elegância recompensam a originalidade, a qualidade ou outros aspectos seletivos (FIVA, 2007).

No que diz respeito à circulação dos veículos antigos, que participam de um evento de antigomobilismo, recomenda-se evitar rodovias e estradas com grande afluência, utilizadas apenas quando é necessário evitar aglomerações ou áreas congestionadas. Outros detalhes são a escolha do itinerário turístico, a ser feita depois de consultar as autoridades locais, e a cronometragem oficial, 
optando-se por áreas amplas que permitam a circulação dos veículos sem obstruir o tráfego normal. O desfile em uma cidade ou em estradas deve evitar velocidade inferior a $20 \mathrm{Km} / \mathrm{h}$, o que deve ocorrer com a cooperação da polícia, observando-se os cuidados com a segurança dos participantes, oficiais e do público. Uma manifestação de antigomobilismo não deve incomodar os demais usuários das ruas (FIVA, 2007). É através da Comissão de Eventos que a FIVA assegura o cumprimento de seu código para a promoção segura de rallyes ou eventos competitivos, sempre de acordo com a Comissão Européia que, recentemente, publicou o Código do Motorista com as indicações gerais aos usuários de veículos históricos.

A exemplo da entidade internacional, a FBVA pretende incentivar a realização de provas pelo Brasil e, para isso, está sendo preparado um regulamento padrão com a proposta de realizar todos os anos um rally nacional. Esse regulamento prestigia a originalidade em detrimento da restauração para premiar os melhores automóveis em cada encontro.

Os encontros de carros antigos vêm se sofisticando e assumindo enfoques específicos. Percebe-se que os eventos possuem um forte elo com as localidades turísticas já que, em geral, o nome do evento incorpora o nome do município. As peculiaridades dos eventos de antigomobilismo podem ser exemplificadas com: o encontro paulista em Águas de Lindóia, que se destaca pela quantidade e variedade de veículos e da feira de peças que acontece concomitantemente; o encontro mineiro, na cidade de Araxá, que definiu como alternativa a elegância e sofisticação; e o Rally de Campos dos Jordão que, em 2004, enfatizou a participação de duplas familiares, isto é, tripulações formadas por casais, pais e filhos ou outras formas, num roteiro de $170 \mathrm{Km}$ em estradas paulistas e mineiras pelas serras da região (Carros Antigos, 2006).

A FBVA coordena o calendário brasileiro de encontros de carros antigos e vem incorporando eventos que, embora tradicionais, ainda são desconhecidos publicamente. A responsabilidade pela realização de cada evento é de cada clube organizador e são realizados tanto em grandes cidades como em inúmeras cidades do interior.

Atualmente, quase 80 clubes brasileiros estão filiados à FBVA, sendo que há, como estimativa, 4.200 antigomobilistas e 21.000 automóveis antigos. A FBVA possui clubes filiados em 14 das 27 unidades federativas do Brasil (Figura 
2), sendo a sua maior concentração nas regiões sudeste e sul, especialmente no estado de São Paulo, com 34 clubes associados, e nos estados de Santa Catarina, Rio Grande do Sul e Rio de Janeiro com, respectivamente, 9, 8 e 6 clubes.

No estado de São Paulo, existem 15 clubes apenas na capital e, nas cidades de Jundiaí, Campinas e Botucatu, 2 em cada uma delas. Na distribuição dos clubes restantes, observa-se certa proximidade com São Paulo - São Bernardo do Campo, Santos, São Sebastião, Taubaté e Jacareí, Jundiaí, Valinhos e Vinhedo - e com Campinas na direção norte do estado - Americana, Limeira, Piracicaba, Pirassununga, Ribeirão Preto, Franca e São José do Rio Preto.

Chama a atenção a existência de clubes de antigomobilismo em pequenas cidades brasileiras. Percebeu-se que municípios com menos de 25 mil habitantes, como são os casos de São Francisco de Paula (20.075) e São Marcos (21.250), no Rio Grande do Sul, e de Pomerode (24.607) e Joaçaba (24.991), em Santa Catarina, também participam do antigomobilismo, um sinal de que o automóvel representa a realidade do patrimônio cultural. 


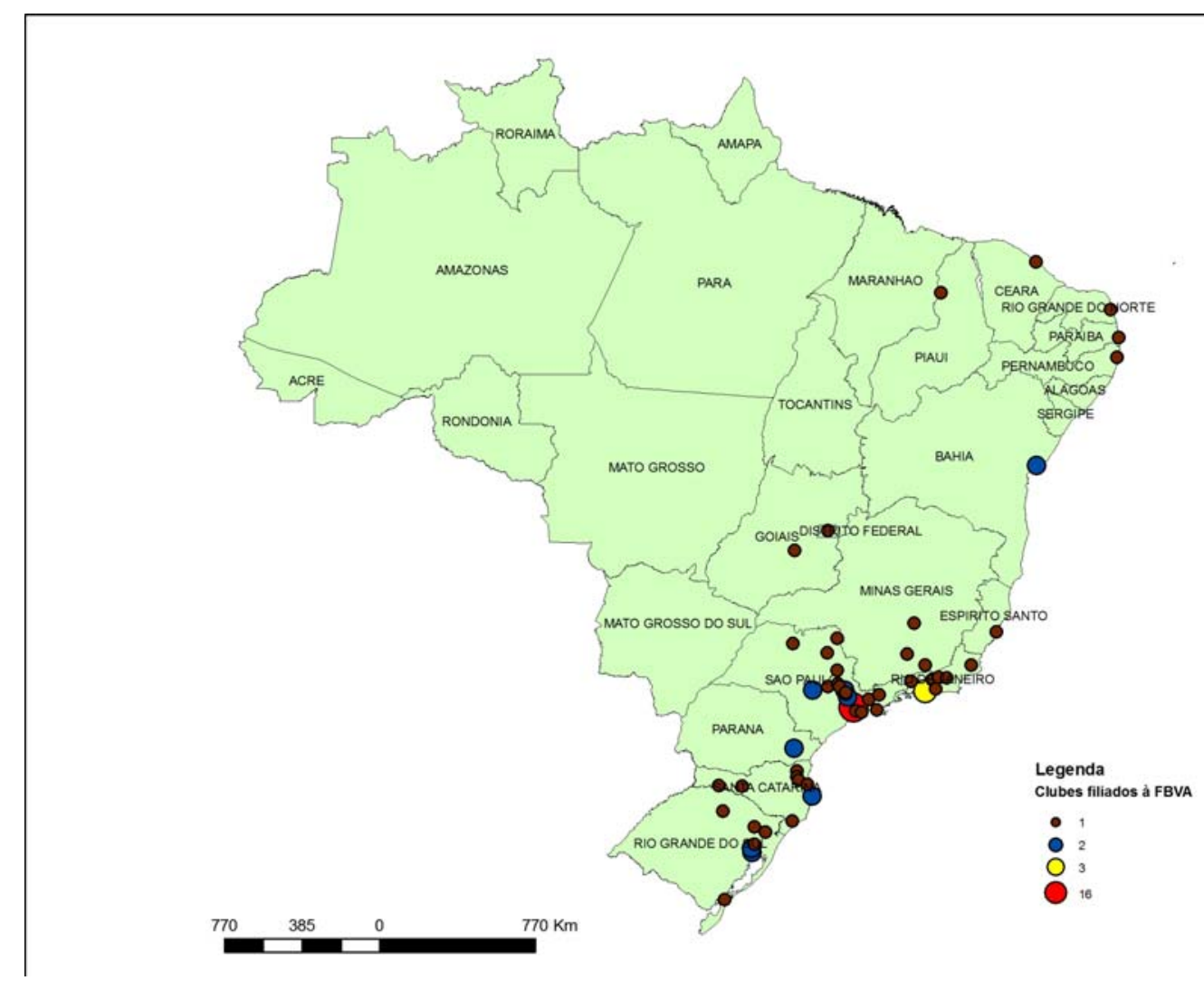

Figura 2 - Clubes de Antigomobilismo filiados à FBVA.

$\mathrm{Na}$ época contemporânea, os clubes de proprietários de modelos de veículos antigos têm a finalidade de trocar experiências e informações sobre adaptações do automóvel, o uso de combustível, acessórios, entre outros. Embora não exista referência, é provável que a idéia de formação desses clubes tenha sido inspirada no pioneiro Touring Club.

O Classic Car Club do Rio Grande do Sul reúne, desde 2001, um grupo gaúcho para trocar idéias sobre automóveis clássicos de alto desempenho. Esse clube tem como objetivo o congraçamento entre antigomobilistas não só do Brasil, mas também de países vizinhos, sendo sua principal característica organizar eventos que incentivam os proprietários de veículos antigos, clássicos e esportivos a realmente desfrutarem de seus carros em provas como rallyes de regularidade em estradas asfaltadas, habilidade condutiva e endurances em autódromo.

Merece destaque o tradicional evento organizado pelo Auto Union Dkw Club do Brasil, em São Paulo, que existe há 28 anos. A disputa da Subida do 
Pico do Jaraguá, em sua $30^{a}$. edição, realiza-se sempre no mês de junho, na estrada que leva ao ponto turístico paulistano na Serra do Japi, é uma competição moldada nas subidas de montanha realizadas na Europa.

Em São Paulo, todo o primeiro domingo de cada mês, na Praça da Luz, em frente ao Parque da Luz, há o Encontro de Carros Antigos que reúne mais de 100 modelos e algumas pessoas participam do evento vestidas a caráter para tirar fotos. A atmosfera torna-se ainda diferenciada por haver no local shows de rock dos anos de 1950 e 1960 (Prefeitura de São Paulo, 2006).

A principal forma de manifestação do antigomobilismo é, sem dúvida, a realização de eventos muito variados: exposições, desfiles, comboios, rallyes e competições. Nos eventos realizados no Rio Grande do Sul, os percursos escolhidos pelos clubes organizadores privilegiam rotas históricas e tradicionais, incluindo viagens aos países vizinhos. Brasileiros também prestigiam eventos realizados na Argentina e no Chile. Um exemplo de evento realizado nos países vizinhos é a prova Mil Milhas Argentinas. Realizada próximo a Bariloche está, atualmente, em sua $19^{\mathrm{a}}$. edição. Dela, participam automóveis fabricados entre 1920 e 1980, homologados pela FIVA, e divididos nas categorias Esporte, GrãTurismo e Turismo, sendo a classificação obtida pelo uso de coeficientes de desempenho baseados na idade e performance dos veículos. A grande paixão dos argentinos pelo automobilismo é disputar nas estradas. Em 2004, foi realizado o II Gran Premio YPF Argentino Histórico do qual participaram 400 automóveis num roteiro de $4.500 \mathrm{Km}$ de extensão, dividido em 6 etapas: Buenos Aires, Villa Carlos Paz, San Juan, Catamarca, Salta, Córdoba e Buenos Aires. Geralmente em maio, acontece, no Chile, o "Rally 1.000 kilómetros Sport Clássicos" com a participação de carros esportivos da década das décadas de 1950 a 1980, num percurso entre Santiago e Temuco. A prova conta como critérios a regularidade, endurance e uma prova noturna, sendo atrativos as paisagens costeiras e montanhosas, que inclui uma passagem pela cordilheira de Nahuelbuta. O autódromo Interlomas foi o local de uma etapa extra que incluiu duas voltas na pista e um trecho de slalom demarcado por cones.

O Club Uruguaio de Automóveis Sport realiza, em outubro, Mil Millas Sport y Históricos, atualmente em sua $17^{a}$. edição. O percurso une as cidades de Montevidéu, Colônia, Salto e Riviera e inclui provas de habilidades nos autódromos de Paysandu e Tacuarembó, além de uma terceira na base aéreas 
de Durazno, no centro do país. Os uruguaios também participam dos eventos brasileiros, como foi o caso do IV Rali Internacional de Porto Alegre em que participaram 17 duplas, representando $50 \%$ dos participantes.

As iniciativas descritas mostram a criatividade de grupos da sociedade na preservação dos veículos, um importante registro histórico que se perderia não fosse a paixão e a perseverança dos colecionadores em mantê-los em sua originalidade. 


\subsection{Fora-de-estrada ou off-road: envolvimento do esporte com o turismo}

Os clubes de jeep e de off-road têm as mesmas características dos clubes de antigomobilismo. Por razões de sociabilização e de interesses comuns relacionados à propriedade, manutenção e utilização dos veículos, as pessoas formam grupos homogêneos no que diz respeito às motivações para o lazer. $O$ entretenimento baseia-se em passeios e as viagens organizadas espontaneamente procuram propiciar o prazer dos membros do clube em dirigir o veículo de sua propriedade.

Para os automóveis fora-de-estrada, as opções são caminhos e trilhas, preferencialmente pouco utilizadas ou intransitáveis, em lugares que um veículo comum não consegue trafegar. Exploradores natos, os esportistas possuem todos os apetrechos para as mais diversas necessidades e desafios que a natureza impõe. Conforme Pires, são apreciadores da lama e de aventuras, colocando antigos veículos em trilhas e na mata, os velhos veículos de guerra que conquistaram muitos adeptos fanáticos (Pires, 2001).

Munidos de mapas e equipamentos que uma viagem planejada requer, por mais desconhecido que seja o trajeto, conseguem informações de outras pessoas que já percorreram os mesmos caminhos, assuntos divulgados comunitariamente e de forma solidária entre todos que têm o mesmo interesse, não sendo nada difícil conseguir planilhas e receber conselhos sobre preparativos e dificuldades previsíveis.

Como descreve Pires, o jipeiro excursionista não conta com serviços de apoio, nem mecânicos especializados em veículos $4 \times 4$ ou lojas de peças usadas, tampouco pousadas e restaurantes ou outros serviços de apoio. Os estabelecimentos existentes são, portanto, aqueles utilizados por todos os que trafegam e moram nessas regiões. Por isso, um jipeiro "deve ser previdente ao extremo, ou o grupo contar com um serviço de apoio próprio" (Pires, 2001). Entre as qualidades pessoais de um jipeiro estão, conforme esse autor, a resistência física e o bom humor e, numa situação limite, o companheirismo, a prudência e o sangue frio. 
Lugares exóticos, pouco povoados e a natureza hostil são atrativos em potencial. Os jipeiros são, conforme Pires, apreciadores da natureza, daquela de difícil acesso. As paradas, tanto são comuns como obrigatórias devido aos atoleiros e constituem a oportunidade para saborear formações rochosas, cachoeiras, vales e corredeiras (Pires, 2001).

Mas a experiência desse público propicia, também, o contato com as pequenas comunidades, pois, como comenta Pires, os jipeiros não gostam apenas de barro. Por natureza, não são apenas curiosos mas também bastante sociáveis, embora nem sempre muito falantes. Possuem bom nível de informação, são sensíveis às idéias de preservação do meio ambiente e de enriquecimento cultural. Desse modo, as melhores excursões de jeep são aquelas que possuem um pouco de tudo: lama, poeira, natureza e o conhecimento da gente do Brasil (Pires, 2001).

Cabe ressaltar que não é apenas de jeep que esse tipo de excursão pode acontecer. Há quem construa seu próprio carro, São os denominados coiotes ou gaiolas, veículos que são colocados para desbravar caminhos e lideram as excursões pela mata. Em Cipó-Guaçu, um sub-distrito de Parelheiros, em São Paulo, uma localidade de periferia onde predominam chácaras e sítios, além de ser uma área incluída no programa de preservação de mananciais, é considerável a oferta de carros usados. Embora inadequados para circular em áreas metropolitanas devido às más condições de sua conservação, são os preferidos por quem pretende construir um veículo próprio, que circule apenas nas redondezas onde o policiamento não impede a sua circulação. Por iniciativa de jovens, esses veículos, preferencialmente fuscas, cujo motor ainda funciona satisfatoriamente, são comprados para se aproveitar a estrutura básica do carro. Toda a lataria é descartada e é feita uma adaptação de banco com, no máximo, dois lugares por questões de segurança. Na parte superior é afixada uma armação de ferro em forma retangular, permitindo visibilidade total já que não possui lataria e vidros. Esse veículo simples, porém muito resistente, permite percorrer estradas de terra e trilhas dos arredores para visitar pontos atrativos da região. Os encontros acontecem sempre nos fins-de-semana entre amigos e conhecidos que possuem, no entanto, carros comuns, de tração $4 \times 4$. Percebeuse que não há qualquer interesse em ampliar o número de participantes, pois é 
preferível conviver com pessoas do mesmo nível social em quem podem confiar, sem se preocupar com o comportamento.

A expansão do automobilismo fora-de-estrada se refletiu na divulgação pela internet. Passeios de off-road com jeeps, motos e gaiolas pelas trilhas de uma região, com diferentes níveis de dificuldade, oferecendo total apoio, além de um almoço especial e sorteio de brindes, constituem a oferta de serviços disponibilizados na internet, sendo a negociação realizada através de contato particular, por e-mail ou telefone. É o caso da II Trilha das Malhas, em Monte Sião (MG), do $1^{\circ}$. Encontro de Jipeiros de Gravatal (SC) e da I Trilha $4 \times 4$ na Serra Gaúcha, em Gramado (RS).

O fora-de-estrada, embora tão disseminado, está sujeito a uma série de críticas quanto aos impactos ambientais. Essa prática remonta, justamente, ao início do automobilismo na França quando as corridas cidade-a-cidade aconteciam em estradas comuns, não pavimentadas, atravessando povoados. Nesse contexto, ainda hoje se mantém os mesmos desafios devido às deficiências das vias de circulação.

A Unijeep - Associação Estadual de Off-road do Estado do Rio de Janeiro, fundada em 1997 e que integra 5 clubes filiados, organiza o Campeonato Carioca Off-road, um rally de regularidade com um percurso de 80 $\mathrm{Km}$ de trilhas na região de Teresópolis, no Rio de Janeiro. Durante um mês, a competição inclui etapas em Juiz de Fora, Teresópolis, Penedo, Niterói, Angra dos Reis e região dos Lagos, sendo alguns trechos da competição realizados no interior de propriedades particulares. As ruas dos arredores da cidade assemelhavam-se a verdadeiras trilhas, por onde, em muitos lugares, apenas carros $4 \times 4$ podem passar.

Dois aspectos, no entanto, mostram problemas decorrentes do comportamento inadequado dos participantes. A organização teve o cuidado de avisar aos moradores, durante o levantamento prévio, sobre o rally que passaria pelas ruas e de estipular, nesses trechos, médias baixíssimas de velocidade. Assustados com os excessos cometidos por alguns competidores, alguns moradores acionaram a Polícia Militar. Esse fato decorreu de um competidor que se exibiu com manobras perigosas, o que levou os demais participantes a refletir sobre comportamentos inadequados (Unijeep, 2007), sendo que é esperado que o rally seja praticado e percebido pelos espectadores como um esporte sadio e 
de elevado conceito. Segundo os organizadores, apenas dessa forma é possível continuar com boas trilhas e conseguir a simpatia do público para as próximas edições do evento.

Outras manifestações de comportamento inadequado recebem críticas, até mesmo, dos próprios esportistas. Praticantes de fora-de-estrada, menos cuidadosos e zelosos, podem deixar rastros por onde passam, sejam as marcas dos pneus por caminhos lamacentos, sejam marcas nas árvores por ter utilizado esse apoio para o guincho tirar um veículo da lama, seja pelo lixo deixado no local onde fazem as refeições. As iniciativas para coibir esses comportamentos indesejáveis, decorrentes de denúncias dos próprios clubes, devem ser orientadas pelo bom senso. As recomendações desses grupos baseiam-se no trabalho de organismos do meio ambiente, que formularam propostas para o planejamento de viagens.

No que se refere à oferta das agências de turismo voltadas para esse segmento, evidencia-se a preocupação em oferecer as características do roteiro, o material necessário e as condições de apoio, tanto no que se refere aos equipamentos como aos profissionais especializados que acompanharão 0 grupo.

A empresa Gaia Expedições, especializada em viagens off-road e expedições para o Brasil e América do Sul, proporcionam o turismo em determinados tipos de ecossistemas. Inaugurada em 2001, por um grupo de profissionais das áreas de engenharia, química, administração de empresas, arquitetura e artes plásticas, a empresa especializou-se na organização e logística de itinerários, apoio mecânico e operacional em viagens, expedições e eventos off-road. É considerada uma referência em viagens de longa distância a bordo de um veículo 4x4 (Gaia, 2007).

Para uma viagem baseada nessas características, o veículo precisa, segundo essa empresa, ser confiável, robusto e ter boa manutenção para que não surpreenda em momentos de dificuldade. Desse modo, qualquer pessoa equipada com um veículo nessas condições pode participar de expedições onde, normalmente, as estradas são precárias e os hotéis nem sempre os mais convenientes quanto ao nível de atendimento. Aspectos relacionados, portanto, a um veículo especial e a idéia de não ser tão exigente quanto à acomodação são essenciais para quem deseja experimentar o turismo off-road. A realização de 
uma viagem de longa duração é assegurada pelo apoio de veículos de uso exclusivo das excursões, além de guinchos, rádio, ar condicionado, pneus especiais, barraca de teto e outras conveniências (Gaia, 2007).

Faz parte da filosofia dos empreendedores e das propostas dos roteiros o contato com localidades isoladas e a atenção quanto à preservação ambiental. Vivenciar belas paisagens da Amazônia também envolve deparar-se com a realidade sócio-econômica da região como o desmatamento, o garimpo e o descaso com as estradas (Gaia, 2007).

A identificação de clubes de jeep e de off-road, feita pela internet, tornou possível dimensionar a amplitude desse segmento do automobilismo. A coleta de dados reuniu 373 clubes, dos quais $48 \%$ estão localizados na região sudeste, $33 \%$ na região sul, $12 \%$ no nordeste, $5 \%$ no centro-oeste e $2 \%$ no norte do país (Figura 3). Essa modalidade esportiva encontra-se distribuída por todo o território brasileiro aparecendo mais concentrada nas proximidades das áreas urbanizadas.

As regiões sudeste e sul apresentam-se como as mais representativas, destacando-se 99 clubes existentes em São Paulo, 56 no Rio Grande do Sul, 44 em Santa Catarina, 43 em Minas Gerais e 31 no Rio de Janeiro. No nordeste, o estado do Ceará possui 10 clubes, seguido de Pernambuco e Bahia que têm, cada um, 8 clubes.

Conforme mencionado, cidades com menos de 25 mil habitantes têm clubes de antigomobilismo. No entanto, essa relação é menos expressiva no que se refere aos clubes de jeep. Por exemplo, Forquetilha, no Rio Grande do Sul, com apenas 2.800 habitantes tem um clube dessa natureza. Isso mostra a popularidade do veículo $4 \times 4$, que prescinde de condições ideais de circulação, ao contrário dos veículos antigos. 


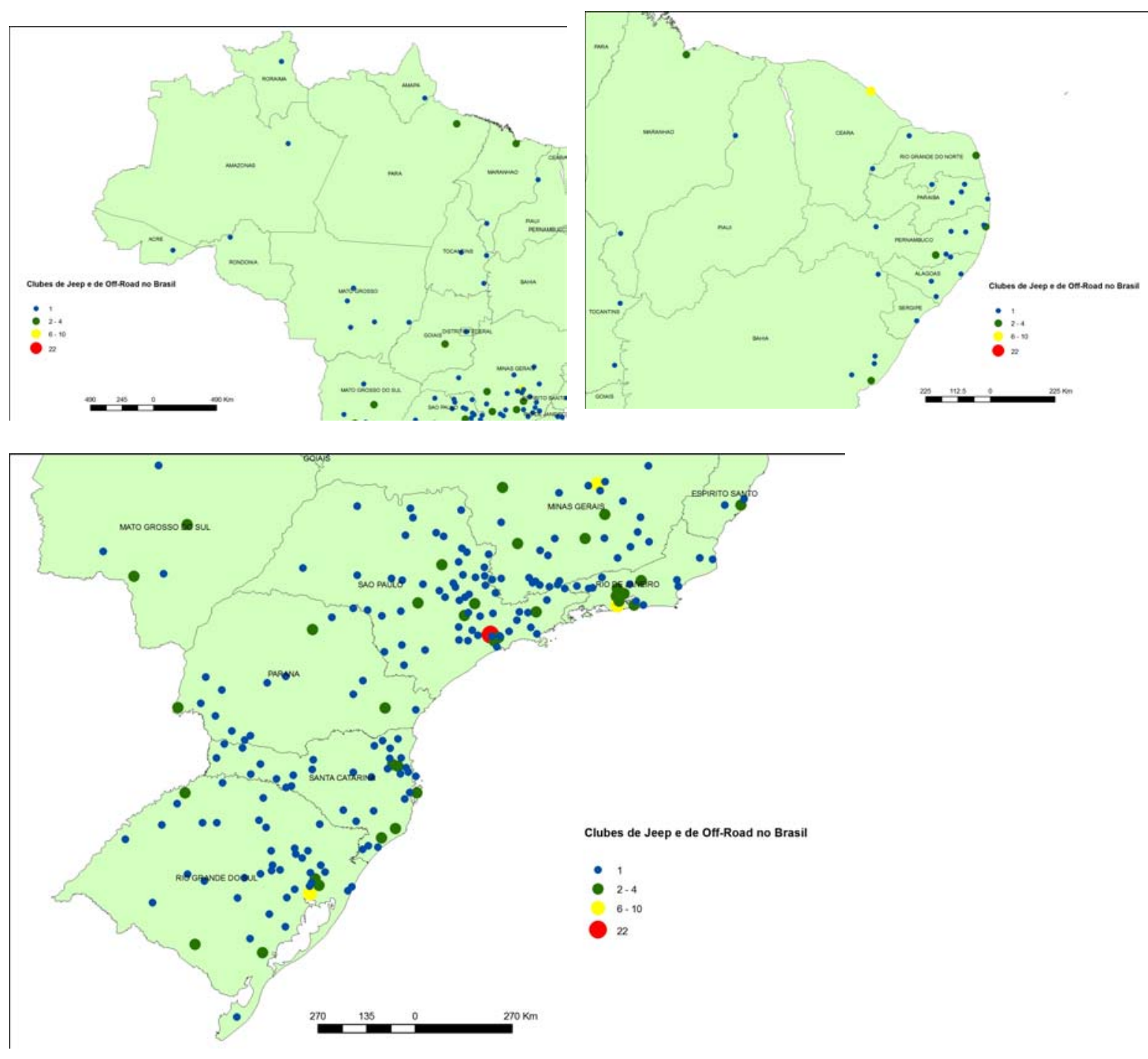

Figura 3 a, b e c - Clubes de Jeep e de Off-road no Brasil.

O Rally dos Sertões, é outro segmento do automobilismo que pode acontecer sem infra-estrutura de acesso. Esse evento, que está em sua $15^{a}$. edição, compreende um longo percurso pelo interior do país, ligando a região central ao nordeste, uma área despovoada e pouco urbanizada. Esse rally constitui uma competição, embora permita a participação de turistas que desejam percorrer a mesma rota e apreciar as diferentes paisagens. A durabilidade do evento só foi possível em razão da profissionalização do rally no que diz respeito à logística, o que contribuiu para que, no meio esportivo, ele fosse reconhecido, tendo suas etapas integradas ao calendário internacional do automobilismo e do motociclismo. 
O Rally dos Sertões, originalmente Rally São Francisco, foi realizado pela primeira vez, em 1990, para 34 motociclistas, num percurso entre Ribeirão Preto, em São Paulo, e Maceió, em Alagoas. Essa foi a primeira iniciativa a revelar o interior do Brasil para competições esportivas, numa proposta de divulgar o país para brasileiros e estrangeiros. Explora-se, até hoje, o agreste brasileiro, onde predominam a caatinga e as chapadas, com a tecnologia dos veículos e com a telecomunicação (Dunas, 2006).

O evento, que sempre contou com a presença de pilotos internacionais, constitui uma da etapa válida para o Campeonato Mundial de Rally Cross Country para motos e quadricíclos, carros e caminhões. O roteiro, mantido em sigilo pelos organizadores como uma estratégia para despertar a curiosidade e o interesse dos participantes, tem, em sua $15^{\mathrm{a}}$. edição, um percurso de $4.000 \mathrm{Km}$ entre Goiás, no Mato Grosso, e Salvador, na Bahia. Em 2007, a visita de representantes da FIA abre a possibilidade para homologar um dos trechos para um dos campeonatos mundiais desse tipo de automobilismo.

Em relação aos alojamentos, durante os 14 dias do rally, é oferecida infra-estrutura de acampamento. Segundo os organizadores, são acomodações em barracas para 16 ou 32 pessoas, sendo que o pacote de acampamento inclui área de box, comida balanceada, instalações sanitárias higienizadas diariamente, lavanderia, sistema de comunicação por rádio e TV, além de internet. O suporte aos eventos esportivos desenvolvido pela empresa de logística oficial já ofereceu esse tipo de serviço aos participantes da Fórmula 1, das 1.000 Milhas Brasileiras e das regatas Cape Tow Rio e a Volvo Ocean Race, competições realizadas no Brasil (Dunas, 2007). Essas providências mostram que, apesar do isolamento das localidades por onde passam competidores, organizadores e participantes, a falta de infra-estrutura turística pode ser amenizada o que, de certo modo explica a viagem e um evento que se mantém por 15 anos consecutivos.

Uma constante no Rally dos Sertões é a sua ligação com personalidades da vida brasileira ou com temas histórico-culturais. Em 1992, por exemplo, o homenageado foi Luiz Gonzaga; em 1994, Guimarães Rosa, autor de Grande Sertão Veredas; e, em 2002, Júlio Prestes. Essa preocupação revela o culto à aspectos culturais relacionados aos valores da música, da literatura e da história. 
Nesse Rally, além dos competidores, há uma categoria específica - a expedition, que reúne participantes com seus próprios carros de passeio com o intuito de fazer turismo, ou nas palavras dos organizadores, "fazer o que os pilotos têm vontade mas, não podem, que é apreciar a paisagem" (Dunas, 2006).

A adoção de medidas de segurança para pilotos é comum a todas as modalidades esportivas e não poderia ser diferente no Rally dos Sertões. Em 2004, por exigência da FIM - Federação Internacional de Motociclismo, foi implantado um sistema de segurança por meio de um aparelho que emite sinal sonoro e luminoso utilizado nas ultrapassagens dentro de uma distância de 150 metros em terreno plano. Essa providência visa a segurança dos competidores, principalmente dos pilotos de motos (Dunas, 2006).

Na promoção de eventos desse tipo destacam-se iniciativas valorizadas pela sociedade. Por meio do Instituto Brasil Solidário, são promovidas duas viagens independentes, além de outra paralela ao evento para atender a população das cidades percorridas no roteiro. Uma equipe de profissionais específicos oferece atendimento médico, distribui material educativo e organiza palestras e oficinas. Em 2002, foram distribuídas 70 toneladas de alimentos (Dunas, 2007).

A equipe "Trilha Limpa", idealizada pelos promotores do Rally dos Sertões, em parceria com uma empresa de ecoturismo, tem como objetivo recolher o lixo do percurso gerado pelo evento. A atividade não se restringe à simples coleta mas envolve a remoção de resíduos provenientes de acidentes com os veículos da competição. Vidros quebrados, pedaços de ferro e fibra como dos pára-choques ou portas, além de derramamento de óleo constituem os elementos recolhidos pelo grupo. Em relação à coleta do óleo, desde 2003, a equipe está preparada com equipamentos específicos para a contenção de óleo derramado, tanto na terra como na água, por meio de um absorvente ecológico industrializado, tecnologia apropriada para esse tipo de serviço e remoção (Dunas, 2007).

Outro evento desse tipo, embora não realizado em 2006, é o Rally do Agreste, cujo projeto estava baseado nas atrações naturais e incluía também os recursos culturais e históricos da região. Os organizadores desse roteiro pontuavam que outras competições ainda não haviam planejado um percurso considerando a atratividade cultural. A proposta era oferecer mais do que uma 
competição esportiva, uma aventura pela história e cultura do povo nordestino (Rally do Agreste, 2006).

O percurso do Rally do Agreste de $1500 \mathrm{Km}$, entre caminhos e trilhas ligando os estados do Rio Grande do Norte, Paraíba, Pernambuco, Bahia, Ceará e Alagoas, cobria parte da rota utilizada pelo cangaceiro Lampião. As cidades escolhidas foram palco de episódios do cangaço, marcados por histórias de violência no sertão, no início do século passado.

Partindo de Natal, em direção a Serra Talhada, chega-se à terra natal de Lampião, um lugar onde se realizavam grandes bailes perfumados, que mais tarde se tornaram lendas. A travessia do Raso da Caatinga, área considerada como o deserto mais seco e árido do Brasil, constitui uma Unidade de Conservação Federal e, por isso, mesmo passando pelo lado externo, o rally é monitorado pelo Ibama.

Em Sergipe, o percurso inclui as margens do Rio São Francisco até Canindé, onde se localiza a Hidrelétrica de Xingó, construída sob os Paredões Rochosos do Canyon do Rio São Francisco. O ponto terminal passa pela barragem do Rio São Francisco com possibilidade de avistar os túneis que desviam as águas que movem as turbinas da usina, além da cidade de Arapicara, em Alagoas.

Em 2007, parte do roteiro desse Rally foi utilizado para competição de duas etapas do Campeonato Piauiense de Enduro de Regularidade, denominado Enduro Rally Rota Norte 2007, um evento supervisionado pela CBA, destinado a caminhões, carros, quadricíclos, além de motocicletas. A corrida provoca aumento na ocupação dos hotéis da região, sendo que os promotores do evento previnem os interessados a planejar antecipadamente sua viagem, informando que os 60 leitos disponíveis estão reservados para pilotos de motos que têm preferência pela impossibilidade de improvisar alojamento.

Os automóveis evoluíram e os modelos fora-de-estrada que entraram no mercado na década de 1990 abriram novas possibilidades para o lazer e para as competições. Em São Paulo, constatou-se um considerável aumento no número de eventos de rally e de velocidade na terra supervisionados pela FASP Federação de Automobilismo de São Paulo, que acontecem em sua primeira ou segunda edição. 
No estado de São Paulo, até o final de 2007, serão realizados 128 eventos nas categorias kart (38\%), rallye (24\%), asfalto $(21 \%)$, terra $(10 \%)$ e arrancada (7\%) (Figura 4). A média mensal é de 10 eventos, sendo mais significativos os meses de abril com 71 ; março com 14; junho com 15; setembro e novembro com 13. No mês de janeiro, porém, acontecem apenas 2 eventos de automobilismo. Autódromos, kartódromos e circuitos abertos fazem parte do local de realização das competições.

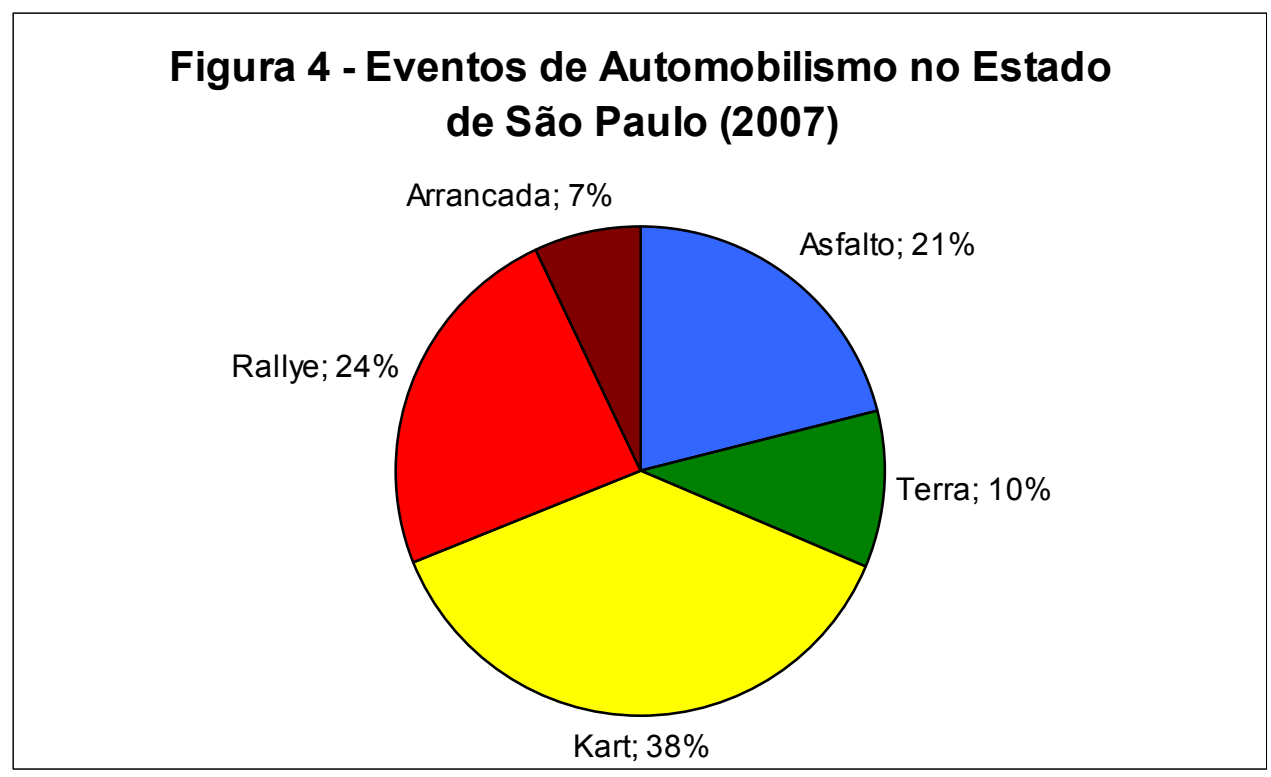

As provas de kart, que representam a maioria dos eventos automobilísticos (38\% ou 48 eventos anuais) são realizadas em 4 espaços: nos kartódromos: de Interlagos e da Granja Viana, ambos na capital paulista; de Aldeia da Serra, em Barueri; e Toca da Coruja, em Bauru. As provas de arrancada e velocidade no asfalto, que totalizam $28 \%$ dos eventos, ou seja, 36 provas anuais são realizadas nos autódromos de Interlagos e de Piracicaba.

Chama a atenção que $34 \%$ dos eventos, agrupando-se as modalidades velocidade na terra e rallye, subdivididos em 4 campeonatos distintos estão sendo promovidos em suas primeira e segunda edições e acontecem em circuitos de diversas cidades do interior de São Paulo.

O envolvimento entre clubes e federações estaduais, visando incluir eventos no calendário oficial correspondente, viabiliza iniciativas importantes como a busca pela profissionalização do esporte e, também, a adaptação da 
infra-estrutura e a organização das competições. O cumprimento das exigências quanto às condições de segurança e quanto à supervisão esportiva das provas, conforme estabelecido em estatutos e regulamentos do setor esportivo, permitem o estabelecimento e o cumprimento de critérios, um processo que influencia a oferta de profissionais especializados e de serviços turísticos nas localidades-sede.

Desse modo, os clubes de automobilismo, incluindo aqueles destinados ao cross-country e ao off-road, desempenham um papel fundamental na organização do esporte, refletindo-se na promoção de eventos. O incremento do esporte e do turismo acontece concomitantemente, pois é fundamental a existência de equipamentos e facilidades de hospedagem e alimentação para todas as pessoas envolvidas.

Mitsubishi, Peugeut e Troller são exemplos do investimento de empresas automobilísticas interessadas em divulgar suas marcas junto aos principais mercados consumidores. Além de patrocinarem equipes e pilotos que participam das competições, abrem espaço para seus consumidores. A Mitsubishi, por exemplo, propõe aos proprietários de veículos da marca a levar mais adrenalina, diversão e competição para o fim-de-semana, numa aventura para o carro e seu proprietário pelos diferentes rallyes criados e organizados pela Mitsubish Motors.

Distribuídas entre as regiões sudeste e nordeste do Brasil, há 5 opções: rallyes Mitsubish Sudeste, Cup Sudeste e Outdoor são realizados nos estados de São Paulo, Minas Gerais, Distrito Federal, Paraná, Santa Catarina e Rio de Janeiro, tanto em circuitos de asfalto como de terra; rallyes Motorsports Nordeste e Cup Nordeste estão presentes em Alagoas, Pernambuco, Paraíba e Ceará. Uma premiação especial é destinada aos proprietários de veículos da mencionada marca produzidos entre os anos de 1991 e 1996. Em qualquer dos eventos, o proprietário pode se apresentar e mostrar a originalidade e a conservação do veículo, ganhando, por isso, o Troféu Diamond, um prêmio exclusivo que exime o concorrente da participação do rally. 


\section{O Autódromo Municipal José Carlos Pace e a Fórmula 1 em São Paulo}

\subsection{O início, as transformações da infra-estrutura e as corridas automobilísticas}

Localizado na zona sul da região metropolitana de São Paulo, no bairro Cidade Dutra, o Autódromo Municipal José Carlos Pace, também conhecido como Autódromo de Interlagos, (Figuras 5 e 6) tem como principal acesso a avenida Interlagos, que pode ser alcançada pela avenida Washington Luis a partir do aeroporto de Congonhas. Considerando o aeroporto de Cumbica, situado no município de Guarulhos, pode-se chegar ao autódromo pelas marginais dos rios Tietê e Pinheiros, até alcançar a avenida Interlagos.

O autódromo está localizado num bairro da zona sul, numa área de proteção de mananciais definida como Z-1 zona estritamente residencial. A região está ameaçada pelo processo de deterioração que atinge a cidade de São Paulo. O trânsito é intenso, há poluição (ambiental, sonora e visual) e problemas de violência. A região sul e a sudeste foram apontadas, pela Fundação SEADE, em 1999, como as áreas onde estão localizados pelo menos seis dos dez bairros mais violentos da capital (RL, 2000).

No bairro do autódromo, a Sociedade de Benfeitores de Interlagos, uma entidade sem fins lucrativos, administra os interesses dos moradores. Essa entidade, em conjunto com a EMURB - Empresa Municipal de Urbanização, está estudando a sua transformação em um "bolsão residencial" dentro do Programa de Implantação de Bolsões Residenciais (PIBR) elaborado pela EMURB. Esta é uma das soluções em pró dos moradores da vizinhança do autódromo internacional (SBI, 2007).

A construção do autódromo de Interlagos decorreu de uma série de fatores relacionados à indústria automobilística em geral, às competições entre as marcas presentes no Brasil, às condições econômicas vigentes e, 
principalmente, à necessidade de um espaço específico que oferecesse segurança para veículos e participantes das corridas de automóveis.

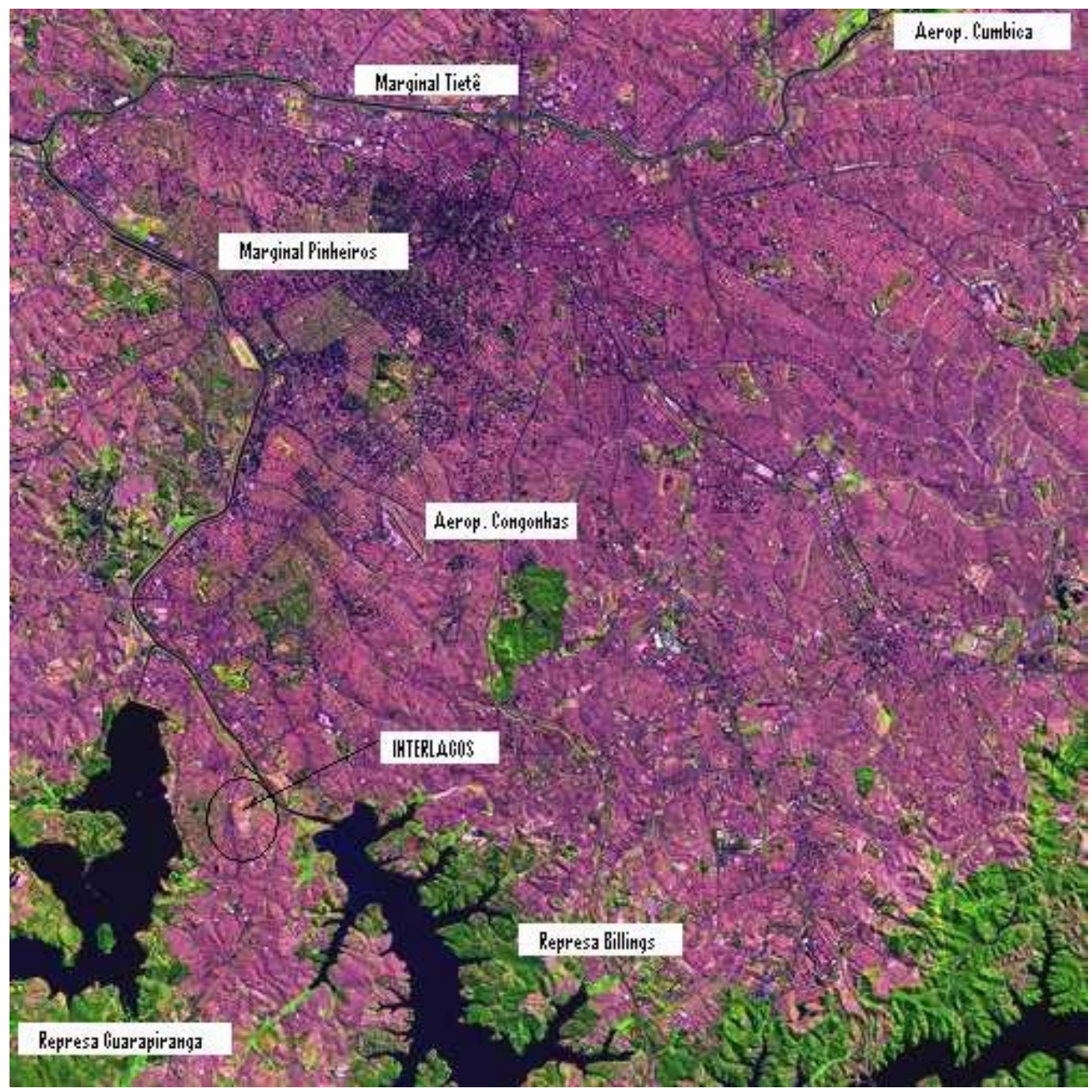

Figura 5 - Imagem de satélite da cidade de São Paulo com destaque ao autódromo de Interlagos, entre as represas Guarapiranga e Billings, além das marginais e aeroportos. Fonte: IBGE, Carta SF-23-Y-C-VI-2, $\quad$ escala $1: 50.000 ; \quad$ disponível em http://www.edbrasil.cnpm.embrapa.br). 


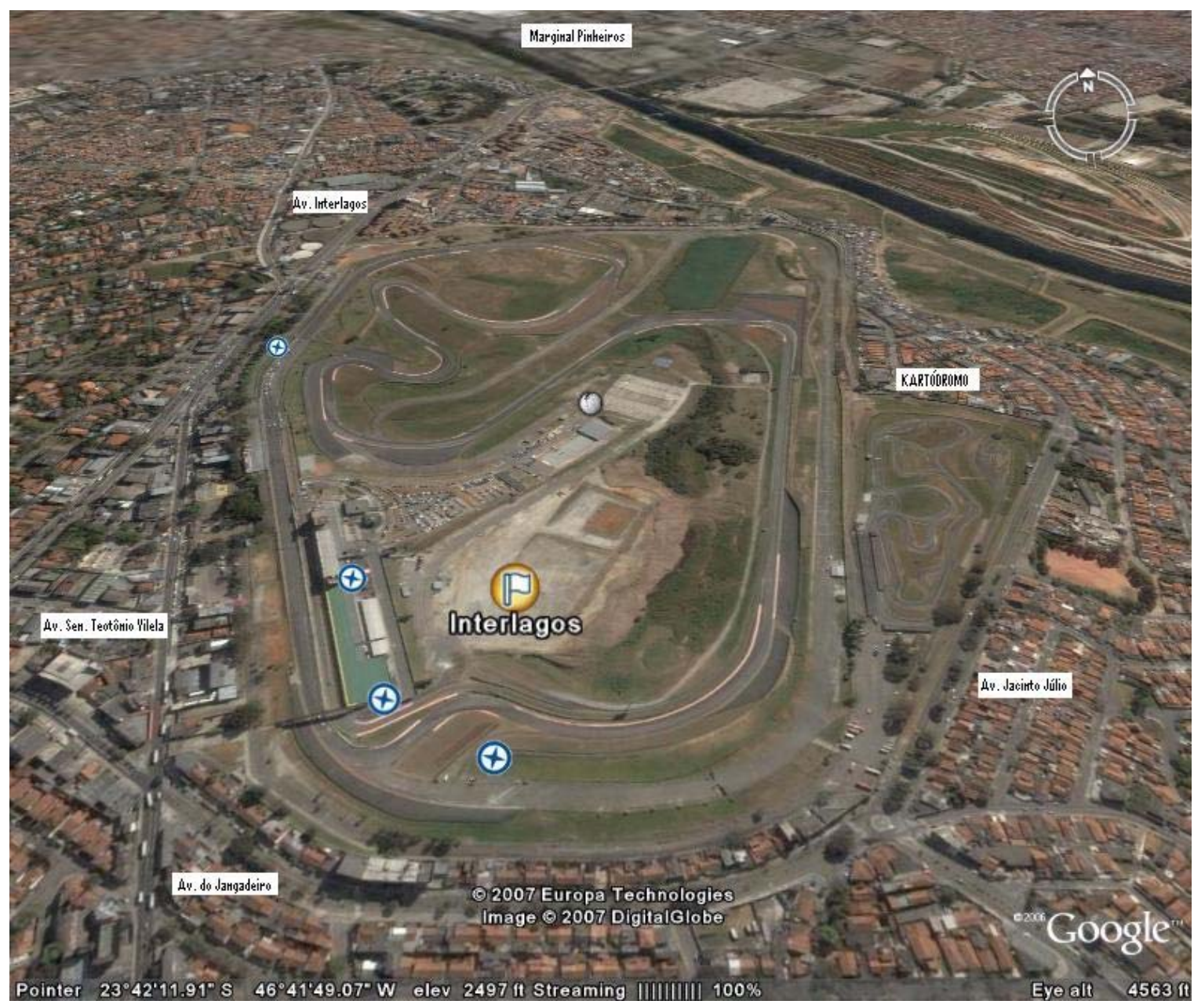

Figura 6 - Imagem de satélite ao autódromo de Interlagos e adjacências. Fonte: Europe Tecnologies, 2007. Digital Globe.

Antes da construção do autódromo de Interlagos, entretanto, várias manifestações do esporte automobilístico aconteciam em diversas partes do país através dos circuitos de rua. Desde o início do século XX, os clubes de automobilismo organizavam pequenos campeonatos locais (GP Brasil Fórmula 1, 2007). A primeira corrida de caráter internacional aconteceu em 1933: o $1^{\circ}$. Grande Prêmio Internacional da Cidade do Rio de Janeiro, realizado no chamado Circuito da Gávea, comumente conhecido como Trampolim do Diabo, pois era um dos percursos mais arriscados do mundo. Era um circuito pelas ruas da cidade carioca, e existiu até 1954. A interrupção deste evento favoreceu a promoção das principais competições, que se realizariam no autódromo de Interlagos, a partir de 1940. (Speed Racing, 2007).

O automobilismo no Brasil, enquanto esporte, ganhou força com as idéias trazidas do exterior, principalmente da Europa, que contribuíram para estimular as chamadas competições, corridas de automóvel ou circuitos de rua. 
Essas competições, a exemplo do que acontecia em outros países, também ocorriam nas ruas da capital paulista. A mais importante delas, realizada em 1936, foi o Primeiro Grande Prêmio Internacional Cidade de São Paulo, que ocorreu no bairro dos Jardins, tendo como pista principal a avenida Brasil. Além dessa avenida, faziam parte do circuito as ruas Canadá, Estados Unidos e Colômbia. O circuito improvisado não oferecia condições ideais de segurança e foi assinalado por acidentes, que preocuparam a população e as autoridades. Constatou-se, assim, que as ruas não tinham condições mínimas de segurança, e que era urgente encontrar outro local para essas competições (SPTuris, 2007).

A necessidade de encontrar um espaço adequado para as corridas automobilísticas levou o diretor do Automóvel Club do Brasil, então diretor jurídico do Banco do Comércio e Indústria de São Paulo, a procurar o empreendedor Louis Romero Sanson (GP Brasil Fórmula 1, 2007), engenheiro britânico, proprietário da AESA - Auto Estrada S.A.. Esse empresário iniciara, em 1926, um projeto imobiliário chamado bairro Balneário e Satélite da Capital, localizado entre as represas Billings e Guarapiranga, à distância da área urbana paulistana. O projeto era ambicioso e previa a construção de grandes vias, de um estádio com pista para atletismo, quadras esportivas, lagos para iatismo e um autódromo. As benfeitorias planejadas visavam alavancar as vendas de terrenos do empreendimento de Sanson (SPTuris, 2007). Junto a Sanson, estava o urbanista francês Alfred Agache e foi ele quem observou similaridades do Balneário com a cidade de Interlaken, na Suíça, e por isso o bairro começou a ser chamado de Interlagos (GP Brasil Fórmula 1, 2007).

A geografia do terreno escolhido para o autódromo permitia visão privilegiada e o aproveitamento de aclives e declives naturais. Após estudar vários autódromos, tais como o de Indianápolis (EUA), Brooklands (Inglaterra) e Monthony (França), e de consultar engenheiros e técnicos especializados, inclusive pilotos experientes (GP Brasil Fórmula 1, 2007), Sanson criou um traçado considerado mundialmente como um dos melhores, com curvas de alta e baixa velocidade e retas longas, formando o que se considerou "a síntese de um traçado perfeito" (SPTuris, 2007). O autódromo de Interlagos foi construído em 1938 e a pista, com $7.960 \mathrm{~m}$, ficou pronta no final do ano seguinte.

O projeto original do autódromo, que também previa a construção de arquibancadas, lanchonetes, banheiros, boxes, torre de transmissão e 
estacionamento para 10 mil carros, entretanto, não pode ser concluído por falta de verbas por parte da AESA. Eram dificuldades financeiras decorrentes da quebra da bolsa de Nova York, em 1929, e das revoluções nacionais de 1930 e 1932. Tais acontecimentos não permitiram que o projeto de Sanson fosse completamente realizado. Mesmo assim, o autódromo foi aprovado pelo Automóvel Club do Brasil, sendo que a inauguração, marcada para 19 de novembro de 1939, foi adiada para o ano seguinte em razão das "fortes chuvas que assolaram a cidade" (GP Brasil Fórmula 1, 2007).

Inaugurado em 12 de maio de 1940, o autódromo de Interlagos apresentava alguns problemas, entre eles o pagamento de pedágio ${ }^{1}$, pois a ponte limítrofe à pista estava localizada em terrenos de propriedade da AESA, construtora do circuito (São Paulo Turismo, 2007). A inauguração do autódromo aconteceu com o $3^{\circ}$. Grande Prêmio Cidade de São Paulo e com uma prova de motocicletas, em que estiveram presentes aproximadamente 15 mil pessoas (GP Brasil Fórmula 1, 2007). A partir da inauguração, foram realizadas, no autódromo, provas de velocidade, como os $500 \mathrm{Km}$ em Interlagos, e as provas de resistência, com duração de 24 horas (Speed Racing, 2007).

O racionamento de combustível decorrente da II Guerra Mundial impediu a realização de corridas a partir de 1943. Só em 1947 as competições foram reiniciadas. Nesse ano, o autódromo sediou a primeira corrida internacional, o chamado Circuito Internacional de Interlagos, com carros Grand Prix que antecederam os carros da Fórmula 1 (GP Brasil Fórmula 1, 2007).

Em 1950, a empresa AESA, que já entrara em crise $^{2}$, vendeu o Autódromo de Interlagos para a Prefeitura Municipal de São Paulo que, na ocasião, estava preparando os festejos do IV Centenário da cidade (Anhembi Turismo e Eventos, 2004), a ser realizado em 25 de janeiro de 1954.

A partir de 1952, com os resultados da implantação da indústria automobilística no Brasil e a entrada de novas montadoras, Interlagos passou a ser um campo de testes para o processo de desenvolvimento de peças e veículos (SPTuris, 2007), tal como acontecia na Europa, nos Estados Unidos e em outros países.

\footnotetext{
${ }^{1}$ Mil e poucos reis.

2 A venda foi efetuada por 23 cruzeiros $0 \mathrm{~m}^{2}$, muito abaixo do valor real que era de 300 cruzeiros o $\mathrm{m}^{2}$ (SPTuris, 2007).
} 
No decorrer do tempo, verificaram-se mudanças e aprimoramentos na infra-estrutura do autódromo de Interlagos, à medida que os conhecimentos técnicos evoluíram e que aumentava o volume de competições e, posteriormente, se acirrava a concorrência entre as marcas presentes no Brasil e, também, entre fábricas da nascente indústria automobilística nacional.

Em 1957, a pista original do autódromo foi dividida em dois circuitos para atender à demanda de testes e de provas: um deles, denominado anel externo, com 3.205m, destinava-se às corridas de alta velocidade. O outro, mais completo, era utilizado em provas que exigiam maior habilidade dos pilotos (GP Brasil Fórmula 1, 2007). Durante três anos, de 1967 a 1970, Interlagos foi fechado para reformas e, em 1971, mais algumas providências preparavam o autódromo para a chegada da Fórmula 1 no país. "O espaço ganhou guias, sarjetas, galerias para águas pluviais, alambrados nas áreas dos boxes, lavadeiras de pista, túnel para acesso ao interior do circuito e um edifício de quatro andares com dependências para rádio, televisão e tribuna de honra" (SPTuris, 2007).

Em 1972, foi realizada uma prova extra-calendário, organizada especialmente para a homologação do autódromo. Uma série de aspectos visando, sobretudo, a segurança dos pilotos nas pistas e, paralelamente, a dos espectadores foram exigidas para que o autódromo pudesse integrar o circuito paulista no calendário oficial do Mundial de Fórmula 1.

O $1^{\circ}$. Grande Prêmio do Brasil de Fórmula 1 foi realizado em 11 de fevereiro de 1973 e São Paulo sediou, então, a primeira etapa do campeonato mundial. A vitória do piloto brasileiro Emerson Fittipaldi contribuiu para popularizar essa categoria no Brasil.

Na década de 1970, um dos programas de quem ia assistir aos eventos automobilísticos era acampar no autódromo de Interlagos, da noite de quintafeira até o domingo. Essa prática de acampamentos em autódromos, que acompanhou o desenvolvimento do automobilismo, era usual também no exterior. Os torcedores europeus também tinham o costume de acampar, especialmente nos circuitos de Hockenhein, Hungaroring, Spa-Francorchamps, Magny-Cours, Ímola, Monza e Silvestone. Já no Japão, os acampamentos não aconteciam exatamente no circuito, mas anexo a um parque de diversões. Por razões de segurança, essa prática passou a ser proibida, e nos circuitos mais 
modernos não há áreas planejadas para campings (Figura 7) (Folha de São Paulo, 2004a; Martins, 2003).

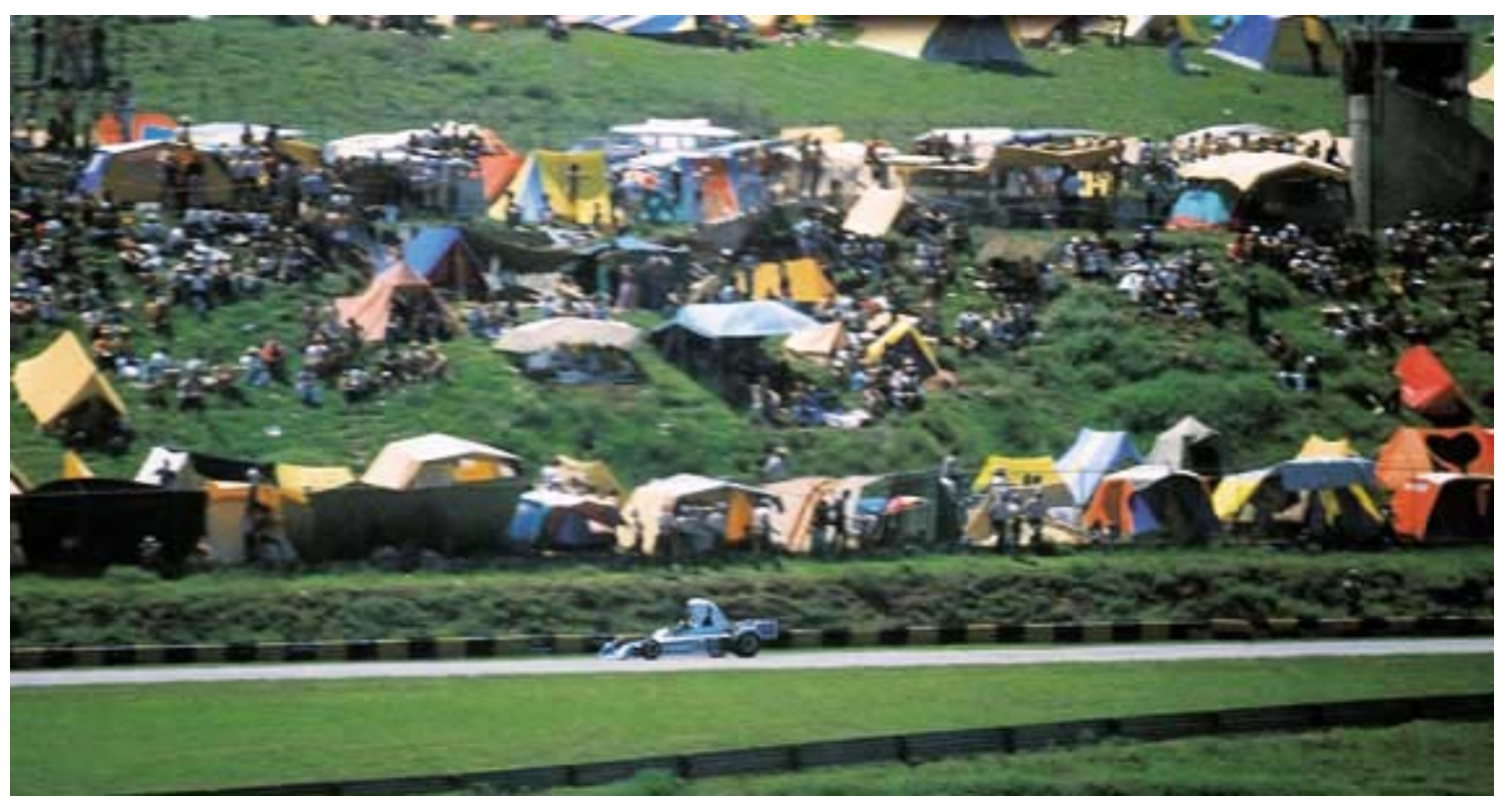

Figura 7 - Acampamentos no autódromo de Interlagos na década de 1970. Foto de J.B. Scalco, Revista Grid, 2007.

Além dessa, outra curiosidade que, ao contrário do acampamento, ainda persiste nos dias atuais, são os "rachas" ou "pegas". Na década de 1970, por exemplo, eram disputados nas principais avenidas que estavam sendo construídas na zona sul. Era o caso da atual avenida dos Bandeirantes, próxima ao aeroporto de Congonhas, e da avenida Ricardo Jafet, em direção à Rodovia dos Imigrantes que liga a capital à Baixada Santista. Essas competições, muito divulgadas e valorizadas pelos jovens, embora polêmicas e consideradas ilegais, ressuscitaram, de certo modo, as antigas corridas de rua, combatidas pela falta de segurança do piloto e da população, motivos pelos quais foram e são marginalizadas. No Brasil, a valorização desses "rachas" privilegia, em particular, a arrancada.

A partir de depoimentos informais de adeptos do automobilismo de rua, verificou-se que esse fato está, também, relacionado ao alto custo de adesão às provas e à falta de eventos que privilegiam essa atividade que, embora considerada por muitos como um risco, vem ganhando espaço em alguns paises. Na Alemanha, por exemplo, adeptos da velocidade podem correr pelas pistas de Nurburg, mediante o pagamento de uma taxa diária Em Londrina, Paraná, as corridas de rua passaram para o autódromo local. Realizadas às 
sextas-feiras, essas corridas entretêm os aficionados pela aventura, pelo risco e pela emoção de correr nas pistas de um espaço real de competição. Significa, na verdade, a busca pela fama pessoal e a possibilidade de conseguir o respeito dos membros do próprio grupo, tanto pela demonstração de habilidades como pelo desempenho do veículo.

A segurança nas provas de automobilismo de alta velocidade sempre foi uma das exigências da FIA, e pode contribuir para explicar, em parte e em certos momentos, os deslocamentos das competições do autódromo de Interlagos, em São Paulo, para o de Jacarepaguá, no Rio de Janeiro. Freqüentemente eram exigidas modificações nos circuitos e, destacada a necessidade de novas obras e de investimentos por parte do poder público. Assim, as competições da Fórmula 1 foram realizadas em Interlagos até 1977. Em 1978, a prova brasileira foi transferida para o autódromo de Jacarepaguá, no Rio de Janeiro. Em 1979, o evento voltou a ser realizado na capital paulista, mas em 1980, a prefeitura de São Paulo não liberou as verbas para a manutenção e adaptação do autódromo de Interlagos. Desse modo, pela segunda vez, a prefeitura carioca aproveitou-se dessa oportunidade e sediou, no Rio de Janeiro, em 1981, a Fórmula 1, fato que persistiu até 1989 (GP Brasil Fórmula 1, 2007). Durante o período em que o Grande Prêmio do Brasil de Fórmula 1 foi realizado no Rio de Janeiro, a Prefeitura Municipal de São Paulo realizou reformas no Autódromo de Interlagos ${ }^{3}$.

O retorno da Fórmula 1 para São Paulo, em 1990, está relacionado à falta de condições financeiras da Prefeitura carioca para manter as condições exigidas pela FIA. Em São Paulo, tanto a CBA como a Prefeitura Municipal se empenharam para que essa empreitada tivesse êxito (SPTuris, 2007). Nessa época, a Fórmula 1, que já se transformara numa atração mundial, promovendo o deslocamento de pessoas dos mais diversos países, contribuiu para incrementar a demanda pelo segmento Turismo Esportivo voltado para o automobilismo.

O Grande Prêmio do Brasil de Fórmula 1, de 1990, marcou a reinauguração do autódromo paulistano e, desde então, anualmente, são feitas

\footnotetext{
${ }^{3} \mathrm{O}$ Autódromo de Interlagos passou a ser denominado Autódromo Municipal José Carlos Pace, em homenagem a essa figura do automobilismo brasileiro, a partir de 26 de dezembro de 1986. Esse piloto renomado do automobilismo nacional, venceu sua única prova na Fórmula 1, em 1975. Faleceu, em 18 de março de 1977, em trágico acidente de avião.
} 
atualizações no circuito objetivando acompanhar o padrão de evolução do automobilismo internacional (GP Brasil Fórmula 1, 2007).

Em 1990, ocasião em que o autódromo completou 50 anos de existência, a pista foi completamente redesenhada e ganhou a formatação atual. O circuito foi reduzido para $4.325 \mathrm{~m}$, como era a tendência internacional e, posteriormente, para $4.309 \mathrm{~m}$, com alterações no traçado ${ }^{4}$, como foi o caso da curva do "S" de Senna, sugerida pelo próprio piloto após a sua consagração como campeão mundial. Além disso, à construção de novos boxes e da torre de controle, somou-se à construção do centro médico e da sala de imprensa. As adequações que, desde o princípio, foram norteadas para oferecer mais segurança aos pilotos e maior comodidade ao público, foram acrescidas de facilidades para garantir a qualidade das transmissões televisivas (SPTuris, 2007).

Ao longo dos anos e até 2003 , as chuvas prejudicaram o desempenho dos pilotos e comprometeram a sua segurança. Vale lembrar que a inauguração, conforme mencionado, foi transferida de 1939 para o ano seguinte em razão das fortes chuvas. Em alguns momentos, as más condições de tempo associadas aos problemas do sistema de drenagem ${ }^{5}$, existentes antes das reformas, transformaram o Grande Prêmio em alvo de críticas de jornalistas nacionais e internacionais. Conforme Ribeiro (2003), a Fórmula 1 desse ano foi intitulada de "corrida maluca" e a prova de Interlagos acabou sendo a mais curta do calendário do mundial desde o Grande Prêmio da Austrália, em 1991, pois completou apenas $17 \%$ de seu circuito (14 voltas de 81 ). Em Interlagos, a corrida parou nos $74 \%$ de sua totalidade. As chuvas, que resultaram em acidentes, fizeram o Grande Prêmio do Brasil lembrar a corrida de 1999, realizada no circuito alemão de Nurburg (Ribeiro, 2003).

O Grande Prêmio de 2003, recordado como um dos mais caóticos da história da Fórmula 1 foi motivo não só do noticiário nacional. O diário italiano "La Gazzeta dello Sport", em editorial batizado "Funeral da Ferrari", ressaltou os pitorescos acontecimentos do Grande Prêmio para contar o terceiro fracasso

\footnotetext{
${ }^{4}$ É um dos circuitos automobilísticos, fora dos Estados Unidos, a ter sentido anti-horário, o que dificulta a prova para muitos pilotos experientes. A pista de Interlagos é a única da América do Sul, a fazer parte do calendário internacional de Fórmula 1.

5 A dificuldade dessa condição para um carro de Fórmula 1 é a chamada aquaplanagem. Em alta velocidade, o carro perde aderência pois uma fina camada de água separa os pneus do asfalto. Se as ranhuras da borracha perdem a capacidade de retirar a água da frente, o carro flutua sobre a lâmina e o piloto perde o controle.
} 
dessa escuderia. O jornal inglês "The Guardian" seguiu a mesma linha, afirmando: "A corrida se tornou uma demolição de proporções épicas e acabou com a maioria dos carros em pedaços após uma sucessão de acidentes".

O Autódromo José Carlos Pace é, atualmente, administrado pela SPTuris - São Paulo Turismo S/A, órgão oficial de Turismo da Cidade, desde abril de 2005. O autódromo possui mais de 1 milhão de $\mathrm{m} 2$, o equivalente a 40 alqueires, e é um dos maiores espaços públicos da capital. Para abrigar as equipes das mais diversas categorias, o circuito conta, atualmente, com 23 boxes de $216 \mathrm{~m} 2$ cada, arquibancadas fixas com capacidade para 18 mil pessoas e toda a infra-estrutura necessária para abrigar provas de diversas categorias automobilísticas. Por ocasião dos grandes eventos, são erguidas arquibancadas tubulares que são montadas ao longo do circuito para acomodar o público (SPTuris, 2007).

Em 2005, boa parte não era utilizada e estava degradada. A segurança era considerada precária, os equipamentos estavam mal-conservados e o mato tomava conta de boa parte do local. Mesmo assim, havia quem se arriscasse a utilizar o local para praticar exercícios. Em 2005, o Presidente da SPTuris, tinha a idéia de investir na segurança e na construção de pistas de skate, praças, pista de cooper e ciclovias, além de levar atividades de entretenimento e esportivas para o local, sem pretender que os investimentos nessas atividades interferissem nos eventos automobilísticos. O objetivo era a valorização do que se chamou "templo do automobilismo" e a criação de um parque que atendesse à população local (Terraz, 2005).

No espaço do autódromo são realizadas outras atividades, ou seja, ele não está restrito à Fórmula 1 ou a competições do gênero. Nele são realizadas outras atividades, entre elas o ciclismo, eventos ligados ao automobilismo, kartismo, escola de mecânica e de pilotagem, lazer da população, práticas esportivas diversas e visitas monitoradas.

Na pista de Interlagos, conforme já mencionado, além do Grande Prêmio de Fórmula 1, acontecem importantes provas nacionais de várias categorias como Stock Car, Fórmula Truck, Fórmula 3, Fórmula Ford, além de provas de motovelocidade. No dia-a-dia da pista, além de treinos, escolas especializadas ministram aulas de pilotagem e direção defensiva (SPTuris, 2007). 
A pista de Interlagos pode ser utilizada para treinos de ciclistas, de segunda a quarta-feira, das 4 às 8 horas e 30 minutos, desde que cadastrados pela Confederação Paulista de Ciclismo. O s ciclistas tinham acesso às pistas do autódromo nos períodos livres das corridas e treinos de automóveis nas pistas. A grande procura e a necessidade de otimizar a utilização do espaço, no entanto, fizeram com que as autoridades definissem critérios,, estabelecendo horários. Novas regras foram introduzidas a partir de maio de 2005 , sendo este o primeiro passo para transformar o autódromo em uma área pública com diversas atividades esportivas. Para os ciclistas essa mudança foi vista como um avanço, apesar de se questionar a iluminação que precisava ser melhorada em alguns trechos e a limpeza de um anel externo de aproximadamente $8 \mathrm{Km}$. Há carência de infra-estrutura para ciclistas, sendo comum a realização de treinos às margens de grandes rodovias, mesmo quando muito movimentadas. A Cidade Universitária, outra alternativa, teve o acesso limitado apenas para funcionários e estudantes e, assim, a população perdeu oportunidade de realizar atividades de lazer num espaço público (Betini, 2005). Interlagos, sem dúvida, preenche uma lacuna em espaços públicos para a prática de esportes.

Outras atividades existem no autódromo que podem ser realizadas em áreas adaptadas para os mais diversos eventos, além daqueles relacionados às competições automobilísticas. Tem sido cada vez mais comum, por exemplo, o uso do espaço para eventos de lançamentos de novas marcas de automóveis e de outros alheios a esse tema. Em novembro de 2000, aconteceu, em Interlagos, o "showmissa" que levou ao autódromo milhares de pessoas para assistir a uma celebração do Dia de Finados (Folha de São Paulo, 2000).

Dentro do autódromo de Interlagos funciona também o melhor e mais tradicional kartódromo da América do Sul, em homenagem a Ayrton Senna. O circuito possui $1.150 \mathrm{~m}$ de extensão, 61 boxes e arquibancada para mil pessoas. É palco das mais importantes competições latino-americanas e, também, o espaço mais procurado pelos pilotos de kart para a realização de treinos. A pista, de desenho ambicioso, tem capacidade para além do traçado oficial, ser adaptado a outros 10 diferentes circuitos, o que possibilita abrigar treinos e provas de diferentes níveis (SPTuris, 2007). 
Três escolas de pilotagem ministram aulas em Interlagos: Centro de Pilotagem Roberto Manzini, Escola de Pilotos Interlagos e Alpie Competições, que serão abordadas em detalhes no capítulo referente aos efeitos.

Uma Escola de Mecânica também existe no autódromo. Desde a sua fundação, em 1991, a EBMI - Escola Básica de Mecânica Interlagos caracterizase como instituição pública, contando com o apoio do SENAI e da Volkswagen. O curso desenvolvido em 6 meses é gratuito e possibilita a profissionalização em um dos segmentos mais disputados do mercado. Nos 15 anos de sua existência, a escola vem sendo mantida graças à Prefeitura de São Paulo, responsável pelo espaço físico, ferramentas e equipe técnica que efetua a seleção dos candidatos e viabiliza a contratação dos instrutores fornecidos pela APAREPA - Associação Paulista dos Reparadores de Veículos Automotores. O SENAI fornece a orientação didático-pedagógica, participa do processo de seleção e emite os certificados. A Volkswagen participa desde a fundação da escola com a doação de máquinas, equipamentos e ferramentas. Essa empresa contribuiu, ao longo dos anos, com verba para uniformes, material didático, reforma do prédio, além da doação de veículos e motores utilizados pelos alunos durante o curso. Mais de 1,9 mil pessoas se beneficiaram da profissionalização oferecida ou da colocação profissional na área. O objetivo do programa é a formação de mão-deobra qualificada e seu público-alvo é a comunidade de baixa renda da Zona Sul da cidade.

Atualmente, o Parque de Interlagos constitui uma importante área aberta à população e possui programação e atividades gratuitas que são oferecidas pela Prefeitura de São Paulo. Uma das preocupações da atual administração é aproximá-lo, cada vez mais, da comunidade local. Para isso, são oferecidos programas como alternativas de entretenimento e lazer gratuito que favorecem a integração da população com seu espaço público. Os usuários têm à disposição 34 banheiros e 3 lanchonetes fixas (SPTuris, 2007).

O autódromo possui um setor esportivo que mantém uma programação com aulas, treinamentos, campeonatos e outras atividades esportivas. Essas atividades são ministradas por técnicos formados em Educação Física. As modalidades são o futebol de salão e de campo, voleibol, basquete, tênis, ginástica localizada e ginástica para a $3^{a}$. idade. Crianças e adolescentes, de 8 a 17 anos, podem participar das escolinhas de esporte e as demais pessoas com 
idade a partir dos 16 anos são atendidas pelas aulas de ginástica. $O$ grupo da $3^{a}$. idade é formado por pessoas com idade superior a 60 anos e que residem nas adjacências do autódromo. Esse trabalho foi iniciado há 4 anos e a intenção era atender 50 pessoas no máximo, em dois dias da semana. Atualmente, são recebidas entre 160 e 170 pessoas durante 4 dias da semana. Cidadania, artesanato, coral, datas comemorativas, atividade física, lazer e cultura são os programas oferecidos (SPTuris, 2007).

Visitas monitoradas integram o projeto Raciocinando em Velocidade. Com duração de 4 horas, é destinado às escolas de ensino médio e fundamental. A proposta é levar o jovem a refletir sobre os perigos da alta velocidade e a fragilidade do homem nessa tão cobiçada aventura que é a velocidade. Apresentam-se as origens dos automóveis, sua evolução e a natureza das competições automobilísticas. Ao evidenciar o fascínio da velocidade também são mostradas as conseqüências o que permite criar uma consciência de como usufruir deste prazer com responsabilidade. O projeto é coordenado por pilotos experientes e graduados em provas de velocidade. $\mathrm{O}$ idealizador do projeto, além de possuir experiência como piloto, foi ex-campeão de kart. Esse projeto, desenvolvido pela SPTuris, FASP - Federação de Automobilismo de São Paulo e Fênix Brasil, inclui a visitação das dependências do autódromo, como boxes, torres de controle e de cronometragem, escola de mecânica e sala de imprensa.

Nos últimos anos, visando reduzir custos com a infra-estrutura do autódromo, a Prefeitura procurou subsídios junto às empresas da iniciativa privada que quisessem utilizar esse espaço para atividades. Por exemplo, a Petrobrás construiu uma arquibancada fixa; a Volkswagen, em 2002, estava negociando, um contrato, de cerca de $\mathrm{R} \$ 200$ mil, para usar Interlagos; e a FIESP, em 2006, pretendia investir em melhores instalações (Jornal da Tarde, 2002).

Outra iniciativa, que partiu da Prefeitura, foi, em 2005, a licitação de pequenos espaços para o comércio em trechos subutilizados do autódromo. A idéia incluía a abertura de bancos, postos de gasolina, restaurantes e lanchonetes. Nesse ano, segundo o Presidente da SPTuris, o prejuízo do autódromo foi de $\mathrm{R} \$ 4,5$ milhões. Entre outras medidas adotadas, estava previsto o aumento do preço de locação das pistas, tanto de automóveis como 
dos karts. Um piloto de qualquer classe ou categoria pagava $R \$ 41,65$, por carro, para treinar um período de quatro horas, o que não correspondia ao custo real para manter o autódromo (Terraz, 2005).

Percebe-se que as contínuas adaptações do Autódromo Municipal José Carlos Pace caracterizaram-se por reformas anuais, sempre considerando as exigências da FIA, preocupada, sobretudo, com a segurança nas pistas. Deve-se ressaltar que essas mudanças, tanto no circuito como em relação às facilidades para espectadores e para a mídia, são fundamentais para manter o autódromo em condições de sediar a Fórmula 1. Além disso, facilitam a realização de outros eventos que ocupam esse espaço, conforme exposto no item referente às modalidades que aparecem no calendário anual.

Esta análise mostrou que, embora o automobilismo tenha grande relevância para o Autódromo José Carlos Pace, existem outras atividades alheias a esse esporte, que extrapolam a Fórmula 1. 


\subsection{O público da Fórmula 1: caracterização geral, distribuição espacial e segurança}

A capacidade do Autódromo José Carlos Pace é de 70 mil lugares; entretanto, o número de pessoas que acorrem ao local nos três dias da Fórmula 1 é muito superior. A demanda para o evento nem sempre se manteve constante. Em 2003, verificou-se que o ritmo das vendas dos 70 mil lugares aumentou em relação ao ano anterior. Considerando-se os treinos de sexta-feira e de sábado, além da corrida do domingo, estiveram presentes 150 mil pessoas. Segundo os organizadores, exatamente 151.456 torcedores, lotaram as arquibancadas e as áreas vip. Foi constatado um aumento de 14,7\% em relação a 2002, quando foram 132.060 pagantes (Agência Estado, 2003a). Havia duas possibilidades para explicar esse aumento de vendas. A primeira refere-se às novas regras da FIA introduzidas na prova de abertura da temporada, depois do Grande Prêmio da Austrália, causando ao público a impressão de que a categoria estava um pouco mais equilibrada e menos previsível (Agência Estado, 2003; Folha de São Paulo 2003). A outra explicação é que o Grande Prêmio do Brasil foi realizado no período da Páscoa, o que coincidiu com um fim-desemana prolongado, favorecendo o aumento da demanda (Agência Estado, 2003).

Numa sexta-feira de treinos, em 2002, conforme a Agência Estado, havia 22 mil espectadores. A simples observação mostrava que esse público detinha um bom nível sócio-econômico, demonstrando ser "fiel e fanático como torcedores de futebol" - embora com as devidas diferenças - e, particularmente, com paixão por automóveis. Predominava, entre o público, elementos do sexo masculino, que acompanhava o evento desde as primeiras corridas da década de 1970. Em 2002, traziam com eles filhos ou sobrinhos crescidos, especialmente aqueles do sexo masculino. Garantiam ser essa "...uma ótima diversão, a violência não existe e posso trazer minha família tranqüilamente". O público feminino aprendia "a gostar do automobilismo" (Agência Estado, 2002b). Assistir a corrida ao vivo é o diferencial para todos os espectadores. Conforme um adepto do automobilismo afirmou: "Fui a todas as corridas desde que a prova voltou a São Paulo, em 1990. Vejo todas as outras etapas pela TV, mas não é a 
mesma coisa. O barulho da F1 ao vivo é incomparável" (GP Brasil Fórmula 1, 2004).

A distribuição do público pelo espaço do autódromo é feita conforme os setores de acomodação, que apresentam diferentes características quanto à localização, à visibilidade da corrida, às facilidades e serviços oferecidos, entre outros, evidentemente apoiados nas possibilidades financeiras de cada um. Assim, o preço do ingresso é definido pela relação custo-benefício.

Conforme pode ser visto na figura 8, à esquerda, aparecem os setores com arquibancadas $A, B, M, D, K, E$ e $G$, destinadas aos convidados de empresas patrocinadoras da Fórmula 1 ou ao público em geral, a preços mais populares. Na ilustração B, à direita, destacam-se os setores vip: Pit Stop Club, Orange Tree Club, Interlagos Club e Premium Paddock Club, cujos preços são mais elevados (GP Brasil Fórmula 1, 1997).

As arquibancadas $A$ e $G^{6}$ proporcionam visões privilegiadas: a primeira oferece visão da largada, parte da reta oposta, curva do lago e a subida; a segunda, permite acompanhar a descida do "S" de Senna, a curva do lago, toda a reta oposta e grande parte do miolo. Cada uma delas permite, ainda, observar partes do circuito que mais emocionam os espectadores: na área central da arquibancada do setor $A$, é possível ver os carros em alta velocidade tanto na reta de chegada, como na reta oposta, do outro lado do circuito; já na arquibancada do setor $\mathrm{G}$, caso o espectador esteja próximo ao final da reta oposta, é possível ver a redução de marchas e algumas ultrapassagens. Para conseguir lugares nesses dois setores A e $G$ as pessoas procuram chegar cedo e ficam horas aguardando na fila.

\footnotetext{
${ }^{6}$ Os ingressos, em 2000 , custavam $\mathrm{R} \$ 205,00$ e $\mathrm{R} \$ 165,00$, respectivamente.
} 


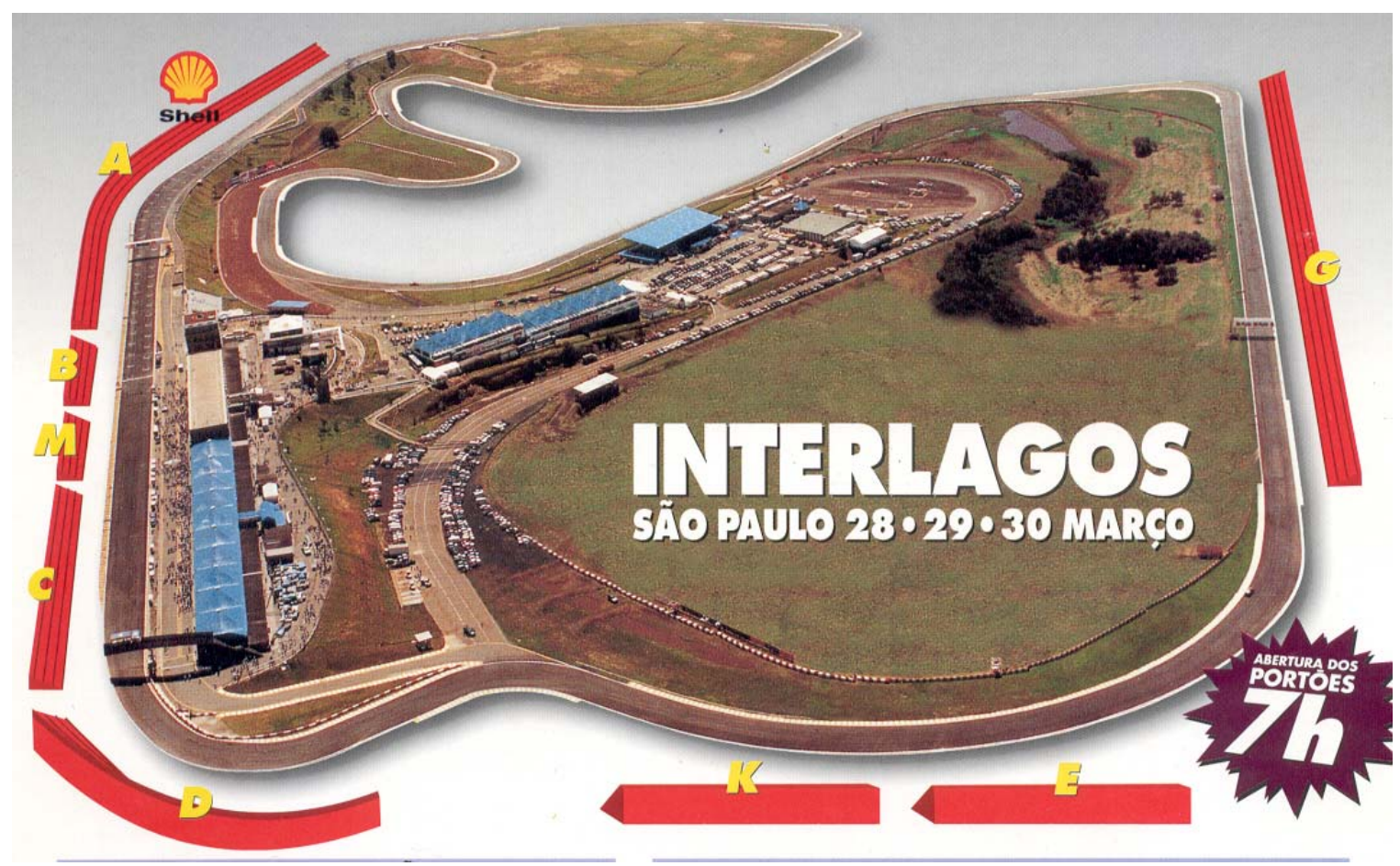

Figura 8 - O autódromo de Interlagos e as arquibancadas do Grande Prêmio do Brasil de Fórmula de 1997. Parte do cartaz divulgação do evento.

O setor G, com capacidade para 20 mil pessoas, foi recentemente coberto e é composto por arquibancadas em estrutura tubular, não sendo, portanto, fixo. O preço do ingresso é o mais barato do circuito. Faça sol, chuva e frio, não importa, a maioria vai bem preparada: protetor solar, capa de chuva, baralho, rádio e até televisores portáteis para aqueles que têm interesse em acompanhar os pormenores (Anzen; Malinverni, 1998). Um "martírio gostoso" para quem atravessa uma maratona de até 28 horas pela abertura dos portões. No próprio dia, constituem uma família improvisada. Garantido um bom lugar, com alguma diversão até o início da prova, essa "família" vai se agrupando a amigos ora conhecidos e estabelecem até núcleos de comando para evitar que surjam os aproveitadores de última hora e consigam um ótimo lugar no setor. Apenas aos membros da "família" é permitido o direito de ir e vir ao banheiro e à lanchonete sem que a saída do lugar não custe a sua perda (Ribeiro, 2003).

As demais arquibancadas (setores $B, M, C, D, K, R$ e $E^{7}$ ) estão, atualmente, cobertas, e têm preços intermediários. Sua venda, porém, nem sempre está disponível ao público pois há negociações com empresas e patrocinadores. Essas arquibancadas permitem maior aproximação aos detalhes

\footnotetext{
${ }^{7}$ Os preços, em 2000, eram de, respectivamente: $\mathrm{R} \$ 480,00 ; \mathrm{R} \$ 430,00 ; \mathrm{R} \$ 775,00 ; \mathrm{R} \$ 450,00 ; \mathrm{R} \$ 360,00$; e valor não revelado pela venda ser indisponível (Revista da Folha de São Paulo, 19mar2000).
} 
da corrida como a visão da largada, a movimentação nos boxes ou a visão geral do circuito. Conforme já mencionado, há quatro setores vip, de uso exclusivo: Premium Paddock Club, Interlagos Club, Orange Tree Club e Pit Stop Club (Figura 9). Esses espaços, destinados a corporações, são negociados diretamente com os promotores. O preço desses setores é divulgado, não em cartazes, mas em propagandas nos principais jornais e revistas. As facilidades oferecidas variam desde a disponibilidade de aparelhos de televisão, do atendimento de recepcionistas treinados e de seguranças, à buffets e eventual acesso ao autódromo por meio de helicóptero.

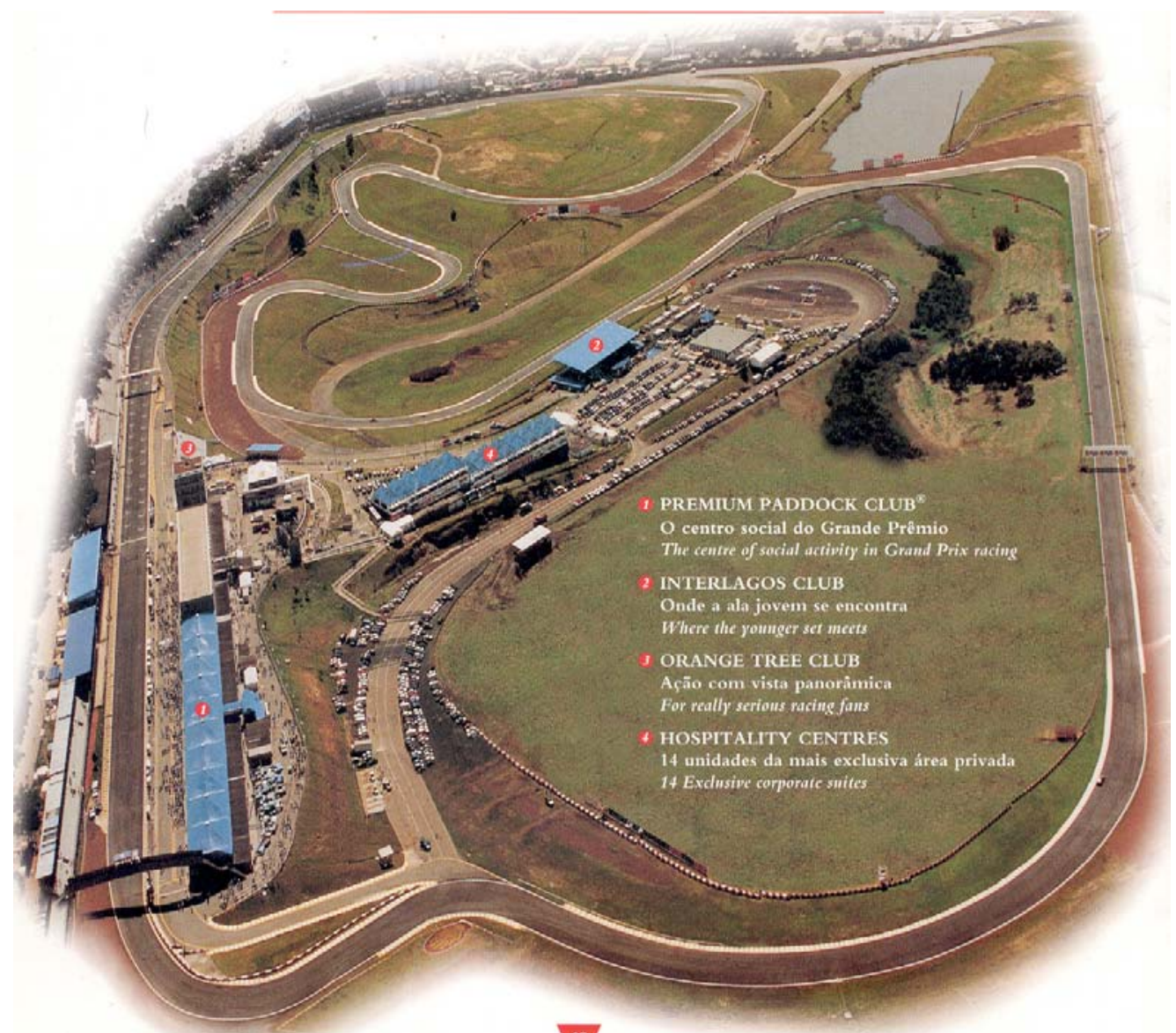

Figura 9 - O autódromo de Interlagos com destaque para os setores vip. Material publicitário do Grande Prêmio do Brasil de Fórmula 1 de 1997.

O Premium Paddock Club é a área vip mais cara ${ }^{8}$ de todas, e oferece o que há de melhor em hospitalidade. Com localização privilegiada, constitui o que pode ser chamado de centro social do Grande Prêmio. Além da possibilidade de chegar ao autódromo por via aérea, esses espaços oferecem buffets durante os três dias do evento e, por estar localizado num pavilhão acima dos boxes, onde é

\footnotetext{
${ }^{8}$ Em 1997, o camarote para 28 pessoas custava U\$ 54.200,00 ou U\$ 1.980,00 a credencial avulsa (Material promocional, 1997). Em 2000, U\$2.450,00 (Revista da Folha de São Paulo, 19mar2000).
} 
possível a visitação depois dos treinos, permite acompanhar toda a corrida, estando mais o próximo possível dela. As demais áreas vip, oferecem diferenciais quanto à visibilidade, aos serviços. O Orange Tree Club ${ }^{9}$, capaz de proporcionar vista panorâmica, está na área famosa que, entre os esportistas, é chamada curva Laranjinha, e permite assistir as disputas por melhores colocações. Quanto às facilidades, esse setor oferece a possibilidade de visitação aos boxes, monitores de TV e cronometragem, atendimento por recepcionistas treinados, sistema de segurança completo, além de banheiros químicos e lanchonete especialmente instalada no local. O Interlagos Club ${ }^{10}$, procurado por publicitários e banqueiros de São Paulo, é o ponto de encontro da jovem e atende a exigências também elevadas. Oferece excelente visibilidade já que está na parte central do circuito. Um renomado restaurante de São Paulo é responsável pelo buffet e, ao público permite-se a visitação aos boxes para acompanhar de perto os trabalhos das equipes. Também há monitores de Tv e cronometragem, atendimento por recepcionistas treinados e seguranças, além da possibilidade de utilizar o helicóptero como meio de transporte. O Pit Stop Club ${ }^{11}$ é uma área privativa, dispõe de espaços amplos para grupos corporativos, sendo construído sob encomenda, com facilidades especiais acordadas com a empresa promotora.

A exemplo do que acontece em outros países, onde os ingressos se esgotam antecipadamente, também no Brasil isso se repete. Nos Estados Unidos, por exemplo, quando, em 2000, a Fórmula 1 foi realizada pela primeira vez no circuito de Indianápolis, os 200 mil ingressos se esgotaram uma semana antes do evento (Salibian, 2000). No Brasil, em 2003, setenta dias antes do GP, os ingressos de três setores já estavam esgotados e isso costuma a acontecer em todos os anos. Nas últimas semanas, só há disponibilidade para os setores mais caros nos quais os ingressos geralmente são vendidos para os três dias do evento (Ishikawa, 2003).

Pretendendo uma provável adequação à demanda, foi criado, em 2004, um novo ingresso, válido para sábado e domingo, sendo que para assistir aos treinos de sexta-feira havia um ingresso específico, vendido exclusivamente nas bilheterias, apenas na semana da corrida (Ishikawa, 2004; Agência Estado,

\footnotetext{
${ }^{9}$ Em 2000, o custo individual era de U\$ 665,00 (Revista da Folha de São Paulo, 19mar2000).

${ }^{10}$ U\$ 1.180,00 era o valor da credencial individual (Revista da Folha de São Paulo, 19mar2000).

${ }^{11} \mathrm{R} \$ 980,00$ era o preço em 2000 (Revista da Folha de São Paulo, 19mar2000).
} 
2002). Em 2004, quando a Fórmula 1 passou a ser realizada em outubro, a venda de ingressos começou bem cedo, no mês de março. Atualmente, a divulgação dos preços de cada setor e a venda começa quatro meses antes do evento. A venda de ingressos ocorre nas próprias bilheterias do autódromo ou através do serviço de telemarketing que oferece mais comodidade e facilidades de pagamento (Ishikawa, 2003), embora em outras ocasiões a venda de ingressos já tenha sido feita em estabelecimentos autorizados pelos organizadores. O serviço de telemarketing possui um horário bastante flexível: das 8 às 17horas, inclusive aos sábados e domingos (Agência Estado, 2003). Nas bilheterias de Interlagos, as compras são apenas à vista. Essa forma de aquisição de ingresso é a mais utilizada pelos estudantes que têm a vantagem de pagar somente $50 \%$ do valor, mediante a apresentação da carteira de estudante (Agência Estado, 2002a) e, por isso, a compra só pode ser efetuada pessoalmente.

A presença de filas é constante, não só para entrar no autódromo no domingo da corrida, mas também às vésperas do evento. $O$ primeiro dia de vendas, em geral, é marcado por filas e, embora diminuam perto do encerramento das vendas, sempre aparece alguém à procura de ingressos.

As bilheterias abrem às 9 horas, porém as pessoas começam a procurálas por volta das 6 da manhã. Em 2002, a espera média era de 3 horas e meia. A maior parte desse público era, e ainda é, composta por estudantes (Agência Estado, 2002).

A entrada do público no autódromo é feita conforme o setor escolhido para assistir ao evento. $O$ setor $A, E$ e $G$ concentram o público mais numeroso e os ingressos são os primeiros a se esgotarem. Os lugares são também os mais disputados e, por isso, imensas filas se formam muitas horas antes da abertura dos portões correspondentes.

As características das acomodações do público interferem no nível de conforto. Assim, os setores cobertos protegem seus usuários do sol e da chuva. Um dos problemas nas corridas automobilísticas de Interlagos, até 2003, quando a Fórmula 1 era realizada em março (mês de chuvas mais intensas em São Paulo) foi a chuva. Além dos já mencionados transtornos provocados nas pistas e na segurança dos pilotos, as chuvas incomodaram o público, principalmente aquele acomodado nos chamados setores populares. Em 2003, por exemplo, 
começou a chover 3 horas antes da corrida e parte desse público ficou desabrigado. Ao contrário, o público mais elitizado podia distrair-se passeando pela comodidade do Premium Paddock, um dos ingressos mais caros do Grande Prêmio (Ribeiro, 2003).

Ainda em relação ao público presente na Fórmula 1 , devem ser ressaltadas algumas questões de segurança envolvendo os torcedores que pretendiam ter acesso aos boxes ou aos seus ídolos. Em 1992, enquanto, nos boxes das escuderias estavam técnicos de diferentes níveis que cuidavam do preparo e da instalação da Fórmula 1, cerca de duas mil pessoas invadiram o autódromo, às 10 horas, atraídas pelo anúncio de uma emissora de Televisão que divulgou ser possível realizar visitas no horário matinal. Temendo um maior tumulto nos portões de entrada, responsáveis pela segurança do autódromo resolveram permitir o ingresso do público, já que ficou difícil conter os ânimos. Os torcedores se instalaram nas arquibancadas em frente aos boxes, de onde observaram o trabalho dos profissionais da Fórmula 1. O pelotão de choque da Polícia Militar chegou a ser chamado para retirar os intrusos, mas depois foi decidido que a medida seria desnecessária. Mais felizes por terem conseguido chegar perto dos boxes, executivos de empresas que co-patrocinam o Grande Prêmio e "penetras" posaram para fotos ao lado das reluzentes carenagens das McLarens de Senna e Berger (Agência Estado, 1992).

Outra questão a ser considerada, e que também está relacionada à segurança, é o fanatismo, muito comum na década de 1970, quando ao primeiro sinal do desembarque de um piloto de Fórmula 1 em São Paulo, os fãs acorriam ao saguão do hotel onde o ídolo ficava hospedado, acotovelando-se em busca de autógrafos e fotos. Atualmente, esse exagero não é mais notado e, no Hotel Transamérica, que é a sede da Fórmula 1, os dias são tranqüilos, principalmente porque a segurança do hotel inviabiliza essas manifestações. Hoje, o movimento em torno dos ídolos, é causado, principalmente, pelos jornalistas que têm acesso ao hotel ou ali estão hospedados. 


\subsection{Preparação do autódromo para o evento}

A apresentação da Fórmula 1 reúne centenas de pessoas: pilotos, técnicos, além de um enorme contingente de trabalhadores temporários ${ }^{12}$, profissionais do serviço médico e da alimentação, engenheiros, bombeiros e outros.

Todos os anos, as condições da pista são aprimoradas, procurando-se atender às condições de segurança exigidas pela FIA. Do mesmo modo, os boxes e os serviços de alimentação são revistos, adaptados e melhorados. Distribuídos por todo o autódromo existem unidades sanitárias do tipo químico, cuja quantidade varia, anualmente, conforme o público ali presente.

A pista do autódromo deve estar adequadamente preparada, seja em relação a suas condições físicas, seja em relação às necessidades de segurança. Há falta de manutenção da pista fora dos períodos da Fórmula 1, já que as outras corridas não necessitam de condições tão apuradas para suas atividades. Desse fato decorrem problemas relacionados ao asfalto, à drenagem e à pintura contra fogo. A imprensa noticiava, conforme mostrou Andrade (2004), que, em 2004, havia rachaduras em alguns pontos da pista e que a reforma da curva do Mergulho ${ }^{13}$, por exemplo, não havia sido feita.

Outras partes da infra-estrutura também passam por constantes reformas para adaptação às novas regras de conforto e atendimento. Em 2003, foram construídos nove escritórios para as equipes na área que fica atrás dos boxes. Esta obra atendeu a uma antiga solicitação dos times que reclamavam do pequeno espaço dentro dos boxes. A partir de então, as salas substituem o motorhome que é oferecido na Europa, isto é, um espaço que tem cozinha e banheiro. Em toda a extensão da Reta dos Boxes, foram colocadas grades de proteção, mais resistentes e mais altas, com 5 metros, sendo similares às usadas em Indianápolis, nos Estados Unidos. A finalidade dessas grades é proteger o público em caso de acidentes (Folha de São Paulo, 2003a).

O serviço de alimentação, também conhecido como catering, envolve a organização de buffets para os camarotes. As empresas que fazem este trabalho

\footnotetext{
12 São cerca de 400 pessoas, a maioria desempregadas que trabalham, dia e noite, divididos em turnos, cortando a grama, varrendo a pista e lavando as arquibancadas, sem contar as reformas estruturais.

13 "Mergulho" é a denominação de um dos trechos da pista de Interlagos.
} 
enfrentam alto nível de exigência por parte dos organizadores em virtude do perfil da clientela. Os horários e os critérios de qualidade são muito rígidos. Não pode haver qualquer problema com o fornecimento, o preparo e o manuseio dos alimentos. As empresas de catering precisam montar uma estrutura própria para garantir a qualidade do serviço. A organização envolve a logística da entrega de alimentos e bebidas em horários planejados e permitidos, além da locação de equipamentos como fogões para o preparo. Todo cuidado é pouco para atender um público constituído de empresários e celebridades que têm em comum a paixão pela velocidade ou pelo glamour da Fórmula 1 (Orgis, 2002). Para atender as arquibancadas, há mais de 30 lanchonetes. Em 2002, foi previsto o consumo de 48,5 mil litros de água potável, além de mais de 150 mil refrigerantes durante os três dias de atividade do evento.

A vistoria da Fórmula 1 é uma constante na competição em São Paulo, assim como acontece em qualquer circuito internacional, e visa verificar se foram atendidas, sobretudo, as condições de segurança exigidas. Participam dessa tarefa, o inspetor de segurança da FIA, o diretor da prova, membro da CBA, e representantes dos promotores do evento e da Prefeitura Municipal. Juntos, verificam as condições do autódromo e orientam as mudanças em visitas nos três meses que antecedem o evento. Nas inspeções, normalmente, o traçado é percorrido à pé, observando-se, detalhadamente, o que precisa ser mudado, o que mostra o alto nível de exigência. O circuito de Interlagos é considerado como o grande laboratório para a FIA. É nesse espaço que os organismos esportivos experimentam o que há de mais novo em relação, principalmente, à segurança dos carros e dos pilotos nas pistas. O enfoque no aprimoramento das condições da pista depende das condições do momento.

Em 2002, o objeto de atenção era o trabalho de substituição da caixa de brita $^{14}$ por asfalto com o intuito de reduzir a velocidade dos carros nos casos de saídas da pista pelas áreas de escape.

Essa mudança de filosofia em relação às áreas de escape atendia aos estudos realizados pela FIA. O assunto havia sido suscitado depois de se investigar os problemas de um acidente, em 1999, no circuito de Silverstone, quando uma Ferrari percorreu $100 \mathrm{~m}$ sobre a caixa de brita e o carro não

\footnotetext{
${ }^{14}$ Brita designa a pedra britada ou quebrada, utilizada para diversos fins, como a construção de estradas, a preparação de concreto armado, entre outros.
} 
conseguiu reduzir a velocidade antes do impacto. Outros pilotos experimentaram situações semelhantes (Oricchio, 2002a; 2002e). Chegou-se à conclusão de que, dependendo da velocidade, a batida acontecia de uma forma ou de outra. O asfalto pelo menos permite ao piloto uma última chance de corrigir o carro. Além disso, possibilitava a sua volta à pista, o que é virtualmente impossível na brita (Revista Grid, 2002a).

O Autódromo de Interlagos foi o primeiro a promover essa mudança que foi considerada a grande novidade do Grande Prêmio para a Fórmula 1 de 2002. Dos bons resultados decorreram alterações em outras pistas utilizadas na temporada (Zukeran, 2002a).

O Grande Prêmio do Brasil era a terceira etapa do mundial. Entretanto, nas etapas anteriores do campeonato nos traçados de Albert Park, na Austrália, e de Sepang, na Malásia, as áreas de desaceleração ainda estavam cobertas por brita.

Acompanhando as mudanças quanto à substituição das caixas de brita por asfalto, houve outras, também em relação às barreiras de pneus. Os pneus são colocados em pontos estratégicos do circuito para amenizar o impacto em caso de acidente (Folha de São Paulo, 2003a). São dispostos 100 mil pneus que visam proteger os pilotos em Interlagos, medidas de segurança, sempre mais reforçadas do que em edições anteriores. Em 2002, foi introduzido um novo método de amarração e compactação das barreiras de pneus. Esta foi mais uma novidade adotada pelos órgãos técnicos da FIA. Os trabalhos foram de desmontagem, revisão, montagem, fixação com parafusos, amarração e cobertura com tela. Em jogos de 35 pneus, cada feixe foi compactado de forma que pudesse ser substituído integralmente em caso de acidente. A produção de um jogo completo levava 40 minutos, um trabalho que teve uma previsão de estar concluído 12 dias antes do evento. A revisão completa na forma de montagem das barreiras de pneus foi conseqüência de acidente no Grande Prêmio da Bélgica de 2001, quando os pneus que se soltaram com a violência do choque colocaram em risco a vida do piloto e dificultaram a ação das equipes de resgate (Revista Grid, 2002a).

A montagem dos 100 mil pneus nas áreas de escape do circuito da Fórmula 1 em São Paulo também foi objeto de preocupação da Secretaria de Saúde da capital, devido à epidemia da dengue (Oricchio, 2002d). O autódromo 
passou a ser vistoriado, uma vez que havia a possibilidade da proliferação de focos de dengue (Zukeran, 2002a). Embora não tenham sido localizados focos da dengue, a Prefeitura exigiu medidas para evitar acúmulo de águas das chuvas nas barreiras de pneus.

A medida adotada pelos engenheiros foi estender uma rede sobre a parte superior dos pneus de forma a impedir a entrada do mosquito (Oricchio, 2002d), mas a Prefeitura, porém, exigiu que todos os pneus ficassem cobertos não somente os de cima. O pedido, no entanto, não poderia ser atendido, pois se a cobertura fosse até o chão haveria perigo dos pilotos envolverem-se em um acidente, o carro enganchar na tela, ao bater na proteção e arrastar todo o bloco de pneus, o que seria perigoso (Zukeran, 2002a), uma falha observada com a cobertura já que elas não impediam a entrada da água da chuva, apenas a dos mosquitos. Assim, como medidas de prevenção, todos os pneus foram furados para evitar a formação de poças d'água.

A campanha contra a dengue, em 2002, constou de distribuição de quatro mil folhetos explicativos distribuídos entre pilotos, integrantes das escuderias e jornalistas estrangeiros e a população em geral, alertando para o problema. (Zukeran, 2002a). A cartilha sobre a dengue, elaborada pelo Hospital São Luiz, foi distribuída em versão on-line, também em inglês, e explicava a forma de transmissão, os sintomas e as maneiras de prevenção da doença ( Agência Estado, 2002).

Em 2003, a preocupação com a vistoria do "parque fechado" substituiu a atenção com a brita nas áreas de escape e com as barreiras de pneus e com a dengue presentes no ano anterior. Um dos pontos da vistoria foi a criação do parque fechado onde os carros ficariam guardados entre o treino classificatório de sábado e a corrida no domingo. Essa mudança foi introduzida, a partir do Grande Prêmio de 2003, sendo São Paulo o primeiro circuito a implementar as novas medidas (Ishikawa, 2003). Dois boxes receberam os carros dentro do regime "parque fechado". A novidade, além de outras mudanças, deveria passar pela aprovação do Grupo Técnico da entidade, em Paris (Ishikawa, 2003I). O box três foi adaptado para receber os 20 carros na noite de sábado para domingo, onde foram instaladas câmeras de vídeo com funcionamento de 24 horas, além de sensores de presença que detectavam qualquer movimento no local (Folha de São Paulo, 2003a). 
Uma das maiores preocupações de todos sempre foi o prazo das obras para a preparação do autódromo para o evento, pois dele depende a vistoria e a competição propriamente dita. A vistoria definitiva das condições do autódromo acontece uma semana antes da competição, sendo antecedida por, pelo menos, duas vistorias extra-oficiais. O noticiário da imprensa, no entanto, revela a apreensão de todos por cumprir os prazos e o cronograma de obras. "A menos de três semanas da chegada das equipes e pilotos e da inspeção final da FIA, as obras em Interlagos para o Grande Prêmio estão atrasadas" (Amaral, 2002). A data estabelecida em contrato entre a Prefeitura e os promotores da Fórmula 1, é de uma antecedência de 30 dias. No entanto, em 2002, faltando 25 dias para o evento ainda havia centenas de operários trabalhando na pista. As obras "mais pesadas" terminariam apenas 13 dias antes. "O cronograma nunca é cumprido, não importa quem seja o Prefeito. Isso acontece desde 1990 quando o Grande Prêmio voltou a ser realizado em São Paulo. Há muitas questões burocráticas que impedem o cumprimento dos prazos" (Amaral, 2002).

A logística e engenharia nunca param de atuar. Sob responsabilidade dos promotores do Grande Prêmio e da diretoria da CBA, operários da Prefeitura e das empresas contratadas preparam o autódromo para receber os pilotos e as equipes. "Pilhas de entulho vão sendo amontoadas perto do box, ao mesmo tempo que arquibancadas são levantadas. Impermeabilização dos telhados dos boxes, da torre, das salas vip e de imprensa, acerto de pódio, colocação de arcondicionado, lâmpadas, conserto de portas e limpeza" (Neves, 2002). As obras são as de sempre: reforma dos boxes, nas salas de imprensa e da FOA TV, até algum paisagismo com a implantação de flores em algumas curvas (Amaral, 2002).

Algumas observações dos jornais e da mídia registram a situação em que estava o traçado da pista: em 2002, o mato beirava a pista, em certos trechos, medindo 1 metro de altura e as caixas de drenagem estavam há muito entupidas (Oricchio, 2002a; 2002e). As observações referiam-se ao "S" do Senna, à entrada da Reta Oposta, à Descida do Lago e à Laranjinha. "A curva do Mergulho, o ponto negro da pista, permanecerá como está por indisponibilidade financeira da Prefeitura. A área de escape desta parte da pista não será nivelada e também não receberá asfalto (Oricchio, 2002a; 2002e). 
Outras notícias informavam que: as obras devem ficar prontas em cima da hora. Em 2002, a pouco mais de duas semanas da disputa do GP e o autódromo ainda era um canteiro de obras (Leite, 2002). O problema principal apontado era a construção de canaletas para a drenagem da água em vários trechos do circuito. "Tanto a área de escape teve a brita substituída como a pista foi nivelada, ambos a pedido da FIA. Só faltavam as canaletas. Dezenas de homens trabalhavam nas obras. Embora muita coisa ainda para resolver, a previsão é que tudo estivesse pronto 45 dias antes do evento (LEITE, 2002).

Em Interlagos, eterno canteiro de obras, a impressão que se tem todos os anos é que as obras são tocadas de última hora e que o autódromo nunca estará pronto para receber o maior evento esportivo do ano no país. Segundo a Prefeitura, a situação não deveria mudar enquanto Interlagos não passasse por uma reforma estrutural (Jornal da Tarde, 2002a).

Ainda em 2002, no período em que antecedia a chegada do delegado de segurança da F1, além da maioria dos pilotos estrangeiros e integrantes das onze equipes inscritas no Mundial, a imprensa mais uma vez mostrou-se apreensiva quanto aos prazos a cumprir e à premência das obras.

Em 2003, o enfoque dos jornais fazia referência ao ritmo dos trabalhos. Nessa ocasião, praticamente todo o sistema de drenagem foi revisto, assim como as áreas de escape e as barreiras de pneus. O asfalto foi substituído em três pontos, na tentativa de corrigir o antigo problema de ondulações do piso (Ishikawa, 2003). Os alertas da mídia sobre as obras do autódromo persistiram em 2004 e nos anos seguintes.

Aproximadamente duas semanas antes da realização do Grande Prêmio do Brasil de Fórmula 1 e, portanto, antes da vistoria realiza-se um ensaio, com os procedimentos de praxe, simulando os problemas que, eventualmente, podem surgir em um evento automobilístico. Os setores de organização técnica e esportiva do evento são os mais solicitados nesse momento.

O objetivo maior do simulado é preparar as pessoas envolvidas, sejam voluntários ou não, para que saibam, com exatidão, como devem agir em determinadas situações. O improviso ou a tomada de decisão momentânea deve ser evitado ao máximo (Neves, 2002a). 
A duração do ensaio geral, que acontece aos sábados, é de, aproximadamente, duas horas. Alguns grupos fazem treinos separadamente mas, às vésperas do evento, todos são reunidos, notadamente as equipes médica, de resgate, bombeiros e de sinalização (Neves, 2002b).

As situações que, normalmente, acontecem numa competição, tal como a largada, são simuladas e o trabalho segue as regras da FIA. Em 2002, por exemplo, sete carros da Fórmula Júnior, uma categoria do automobilismo que é promovida pela CBA, estiveram na pista para ensaiar as situações de teste dos setores envolvidos. Cerca de 300 pessoas estavam reunidas, atuando na estrutura esportiva, sendo que, no dia do evento, há mais de 600 credenciados (Neves, 2002b).

Numa simulação da largada e de um possível cancelamento, é avaliada, por exemplo, a atuação dos "empurradores", aqueles que removem os carros que ficam parados no grid. Inclusive é treinado o movimento das placas indicativas, específicas do automobilismo para que no dia da corrida propriamente dita aconteça de forma correta e sincronizada (Neves, 2002b).

Ensaios práticos em relação às equipes de apoio ao box, à pista e aos resgates que são a pé e motorizados também são realizados. Normalmente, cerca de outros cinco procedimentos são avaliados, cada qual com sua equipe, serviços e local respectivos (Neves, 2002b). Entre as simulações realizadas, uma das principais é a de um acidente na pista e o deslocamento da ambulância para esse ponto. O primeiro atendimento acontece no local e, posteriormente, o piloto é transferido para o Centro Médico, do Hospital São Luiz, que existe no próprio autódromo. Em casos mais graves, o piloto é encaminhado para o próprio Hospital São Luiz, no Morumbi, via helicóptero (Revista Grid, 2002b).

Os pilotos dos carros de intervenção, responsáveis pelo resgate dos pilotos em caso de acidente, não são simples motoristas, mas pilotos profissionais preparados para situações de emergência. Os carros de intervenção são de extrema importância em caso de acidente. Levam dois médicos e um bombeiro especializado que são os primeiros a chegar no local para prestar um atendimento rápido e eficaz. Por isso, há necessidade de condutores que conheçam muito bem o traçado. "Eles não só conhecem a pista, como seus atalhos também. Isso é uma garantia de uma cobertura rápida". No grupo de primeiros socorros estarão também os carros de resgate com dois 
médicos e quatro bombeiros que serão conduzidos pelos alunos da Escola de Pilotagem, além das ambulâncias e do "medical car" dirigido por um ex-piloto que leva o médico-chefe (Revista Grid, 2002c).

O pessoal de resgate, também chamado de "anjo da guarda" dos pilotos de Fórmula 1, não usa roupa branca e nem se locomove de ambulância. Para maior segurança, esses profissionais, principalmente no caso de incêndio, vestem macacões confeccionados em tecido anti-chama, na cor azul. O medical car e os carros de pronto atendimento não são ambulâncias, e sim modelos perua da marca Volvo. A opção por esses veículos tem como objetivo acelerar o atendimento aos acidentados, pois esses carros são mais rápidos e potentes do que as ambulâncias.

Em 2002, o Centro Médico do Hospital São Luiz, montado no autódromo, foi integralmente reformado. A obra atendeu a todas as exigências da arquitetura hospitalar moderna. Cantos arredondados, visando maior higiene, além de uma divisão dos ambientes, tornaram o espaço bem mais funcional (Oricchio, 2002c). O objetivo foi separar o atendimento de casos de emergência, relativos aos acidentes graves de pista, dos atendimentos de rotina de prontosocorro, como casos de mal-estar. Por exemplo, nesse mesmo ano, o calor foi a causa da maioria dos atendimentos dos organizadores, das equipes e daqueles que ocupavam as áreas vip. O mesmo aconteceu nos três postos médicos localizados em diferentes lugares do autódromo, prontos para atender o público das arquibancadas. Foram 231 atendimentos. Um número pequeno se comparado à quantidade de pessoas que assistiram à corrida. Os espectadores procuraram o atendimento médico por problemas de mal-estar e de pressão, sintomas comuns quando se trata de calor. Alguns casos de ferimentos leves, como pequenos cortes, também foram registrados. No centro médico, casos de infecções respiratórias e pequenas contusões somaram 104 atendimentos (Revista Grid, 2002c).

A preparação do autódromo para a Fórmula 1 exige, ainda, infraestrutura tecnológica. Em 2002, a organização do Grande Prêmio do Brasil investiu na área de informática exclusivamente para a corrida. O sistema de informações passou a controlar e orientar o trabalho de todos os 565 comissários de pistas envolvidos com a corrida. A novidade foi a informatização dos membros em seus respectivos postos de trabalho. Até aquele momento, tudo era 
feito por meio de planilhas. Conforme o diretor de Operações, "Trocamos o papel pelo computador. Com isso, há uma completa agilização das informações e, como conseqüência, maior eficiência" (Neves, 2002b).

Para a viabilização do sistema, em 2002, foram instaladas 32 câmeras digitais, que enviam imagens dos 4.309 metros da pista, para a torre de comando, recebendo, então, informações exatas sobre o posicionamento do pessoal que trabalha no pit lane, nos postos de sinalização, no centro médico, no resgate e no corpo de bombeiros. Em caso de acidente, pode-se saber, com rapidez e segurança, quais os postos de trabalho que estão cobrindo aquele ponto. Cada pessoa representa um posto. No sistema esportivo, atualmente informatizado, o controle verifica a necessidade de algum reforço e emite ordens para a atuação de outros postos. Com a implementação do sistema foi possível cobrar mais eficiência do pessoal. O desenvolvimento do projeto teve um custo aproximado em US\$100 mil, o que foi pago pela organização do Grande Prêmio (Leite, 2002b).

A tecnologia avançada permite, aos profissionais, controle total do que se passa na pista durante a corrida. Conforme explicou o diretor da CBA, "Agora tudo será mais ágil e as minhas indicações para o pessoal da pista ficarão mais fáceis. Posso pedir que movam um carro para frente ou para trás, sem qualquer dúvida de que isso é o mais correto e que não atrapalhará a corrida". Além das novas câmeras, há outras 26 da Rede Globo de televisão que continuam auxiliando a torre de controle. Novos equipamentos foram instalados também nos boxes e em cinco postos de controle. Na Torre de Controle, as imagens são todas gravadas, o que permite análises futuras. Mesmo durante a corrida, os pequenos detalhes podem ser ampliados para avaliar os procedimentos que realmente devem ser adotados, sem que isso interrompa outras operações do sistema de informação. 


\section{Análise dos Efeitos do Grande Prêmio na Capital}

\subsection{Patrocinadores do evento e das equipes}

A fim de facilitar o entendimento deste capítulo, fez-se a classificação dos efeitos em grupos abrangendo: patrocinadores e empresa parceira; patrocinadores de equipes; oferta direta de produtos e serviços; lazer e entretenimento; aspectos do acesso e da segurança; e eventos paralelos.

A análise das questões relacionadas a esses temas foi direcionada para a divulgação de marcas, produtos e serviços englobados no marketing, cujas evidências transparecem no entorno do autódromo municipal José Carlos Pace e em algumas áreas da capital paulista.

O marketing de marcas, produtos e serviços, no turismo, constitui um conjunto de métodos e de técnicas direcionadas aos visitantes, à população, às instituições e associações. No caso da Fórmula 1 em São Paulo, são visíveis certos aspectos relacionados à publicidade, uma das vertentes da comunicação comercial expressa nos banners, nos cartazes e na folheteria. Essa relação de comunicação com o público-alvo está estritamente vinculada aos aspectos psicossociais, envolvendo diferentes tipos de motivações com destaque para aqueles relacionados à diversão e ao entretenimento. A publicidade presente na Fórmula 1 mostra que outras motivações também são exploradas como, por exemplo, aquelas ligadas às necessidades de aceitação, ao ego e à auto-estima.

Sem dúvida, o final de 1990 e os primeiros anos de 2000, foi uma época de uso indiscriminado de qualquer espaço que oferecesse visibilidade pelas ruas próximas ao autódromo, que estava "disponível para propaganda" (Figura 10). Muros e postes completamente abarrotados de mensagens, as mais diversas possíveis: compra e venda de terrenos e casas, oferta de cursos profissionalizantes, candidatos políticos e a propaganda de bebidas são alguns dos muitos exemplos que poderiam ser citados como elementos integrantes da poluição visual no bairro e, também, na própria cidade.

Como não poderia deixar de acontecer, os patrocinadores e a empresa parceira da Fórmula 1 promovem marcas e produtos, utilizando para isso pontos estratégicos nas principais vias de acesso e no entorno do autódromo onde 
acontece a Fórmula 1. Para esta pesquisa foram escolhidos alguns exemplos capazes de ilustrar o uso da publicidade que explora apelos, conceitos e imagens relacionando-os às características de um produto, visando um determinado público-alvo. Os variados exemplos aqui expostos privilegiam produtos e serviços de uso corriqueiro como locação de veículos, cerveja, pneus e combustível. Trata-se, exatamente, de alcançar o consumidor comum presente numa metrópole, ou seja, exatamente aquele que pode procurar o autódromo para assistir ao evento da Fórmula 1. Deve-se considerar, entretanto, que mesmo não comparecendo à Fórmula 1, as pessoas podem vir a consumir esses produtos e serviços em virtude da força da mídia que proporciona o registro de um conteúdo associado ao evento.

A Unidas, locadora oficial do Grande Prêmio do Brasil de Fórmula 1, realizado em 2004, destacava no outdoor, na avenida dos Bandeirantes, a relação com a coragem de seus clientes que "vivem a $300 \mathrm{Km}$ por hora" (Figura 11). Da mesma forma, a cerveja oficial desse mesmo evento, apoiou-se na Fórmula 1 para o lançamento da Nova Schin, com rótulo comemorativo que evoca a Fórmula 1 (Figura 12). Paralelamente, conforme Meio \& Mensagem (2004), essa mesma empresa maximizou o investimento do seu patrocínio na Fórmula 1 criando o campeonato de automobilismo virtual. Os internautas puderam, assim, pilotar um carro de corrida em alguma das pistas mais famosas do calendário da competição, sendo que os pilotos mais rápidos, em três etapas classificatórias, encontraram-se pessoalmente para um desafio final no circuito de Interlagos. O primeiro colocado ganhou uma viagem para assistir à Fórmula 1 em São Paulo, além de outros kits. Esta iniciativa foi divulgada nos principais portais do país em canais que possuíam afinidade com o público e o tema.

Explorando a vitoriosa conquista de seis títulos mundiais de Fórmula 1, a Bridgestone, fabricante de pneus e patrocinadora da Ferrari destacou a "paixão pela excelência" (Figura 13). Por outro lado, a Petrobrás, que forneceu o combustível para a equipe BMW Williams estabeleceu uma analogia de seu produto com a energia dos pilotos (Figura 14).

Nas proximidades do autódromo José Carlos Pace, todos os postos de combustível da rede Shell (o que se ampliou pela cidade de São Paulo), divulgaram concursos de prêmios Ferrari a quem abastecesse naqueles estabelecimentos. Justifica-se esse empenho pelo apoio da Shell às equipes da 
Ferrari que participavam da Fórmula 1 (Figura 15). Outro outdoor, também da Shell, apontava a "Shell V-Power. A gasolina campeã da Fórmula 1" (Figura 16).

A DHL - empresa parceira da Fórmula 1, ligada ao trabalho de logística oficial, evidenciava a velocidade como o seu negócio, destacando as cores da empresa nesse evento, expressas na bandeira quadriculada em preto e branco, que é acenada no final da competição. A bandeira utilizada na propaganda, em vermelho e amarelo, mostrava a empresa de logística como se estivesse integrada à vitória, já que sob sua responsabilidade estão todos os equipamentos da Fórmula 1 encaminhados a cada um dos circuitos do campeonato mundial (Figura 17).

Patrocinadores do evento e empresa parceira garantem a realização da Fórmula 1, proporcionando recursos financeiros e divulgando o evento nacional e internacionalmente.

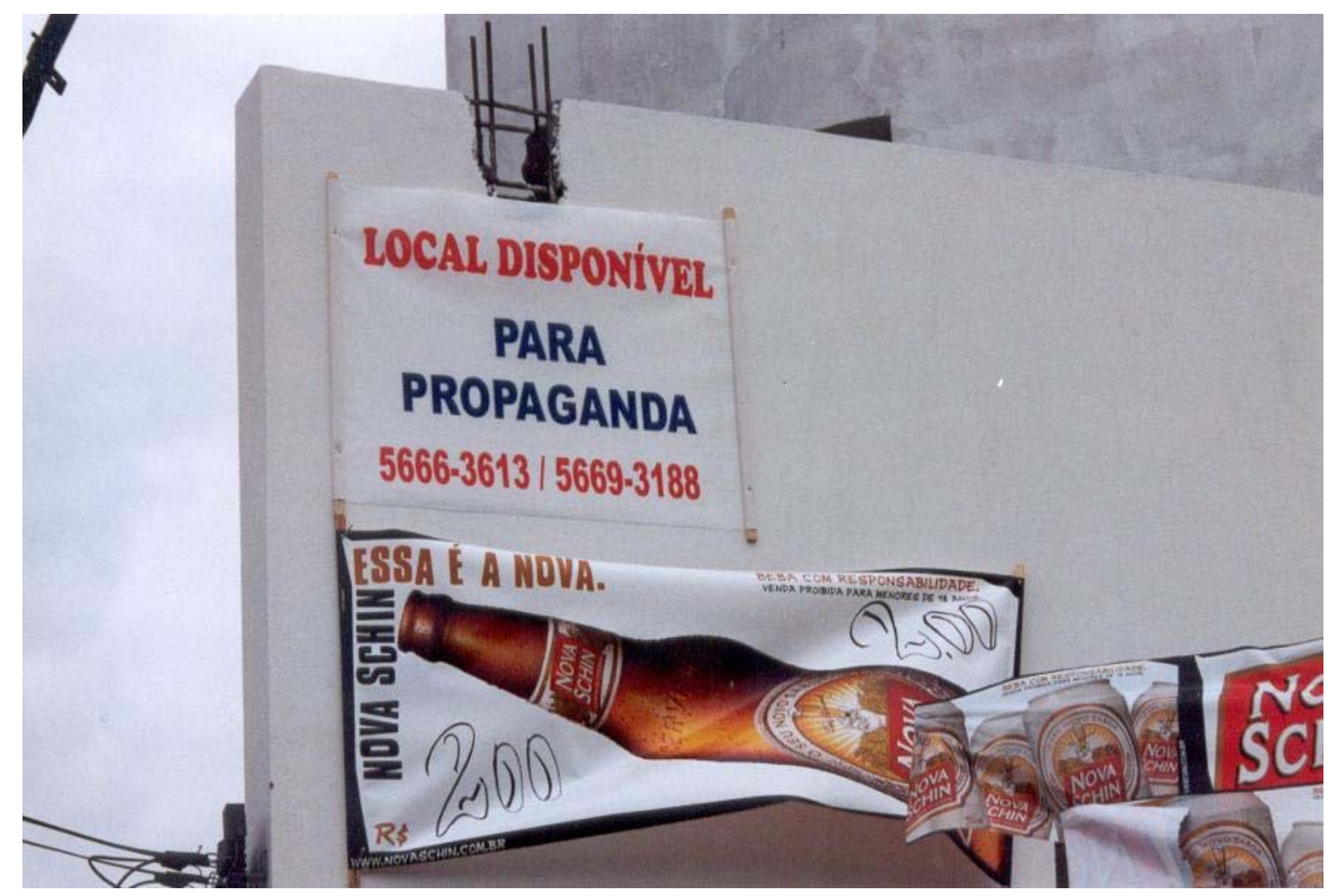

Figura 10 - Uso indiscriminado de qualquer espaço que oferecesse visibilidade (2004). 


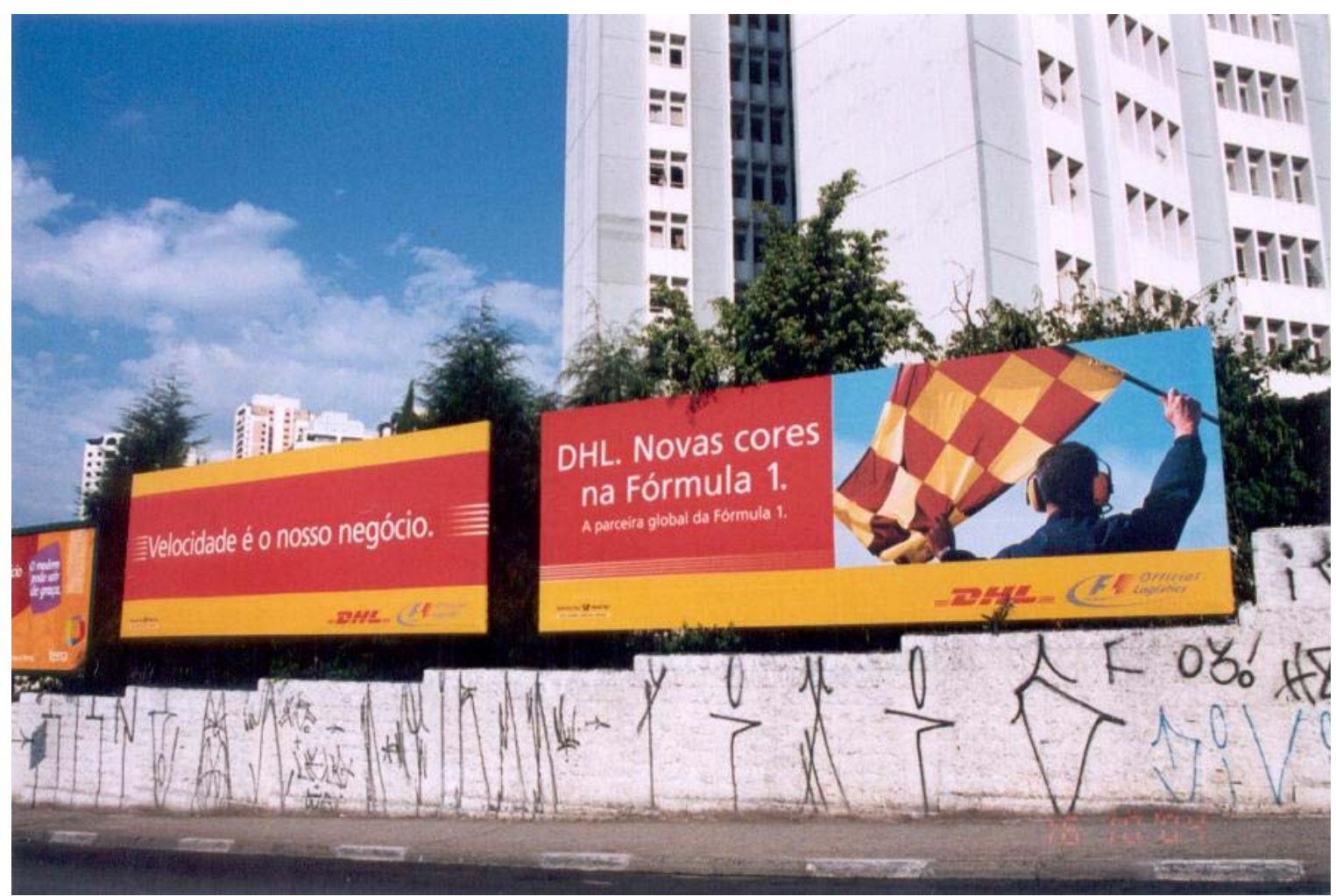

Figura 11 - A Unidas, locadora oficial da Fórmula 1, enfatizou que seus clientes vivem a 300 $\mathrm{Km} / \mathrm{h}$.

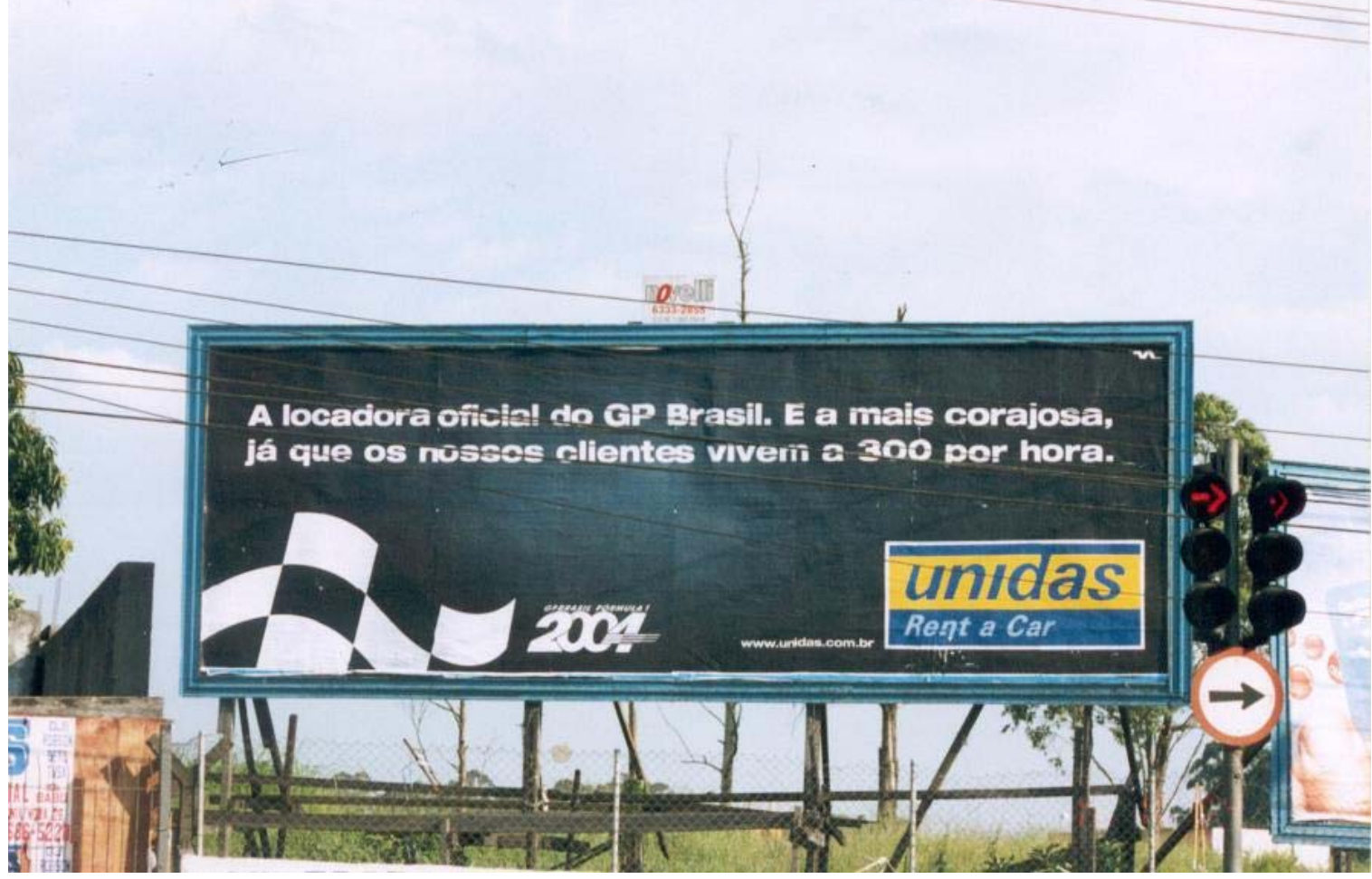

Figura 12 - A cerveja oficial da Fórmula 1 fez o lançamento da Nova Schin, um novo produto, com rótulo comemorativo que evoca a Fórmula 1 (2004). 


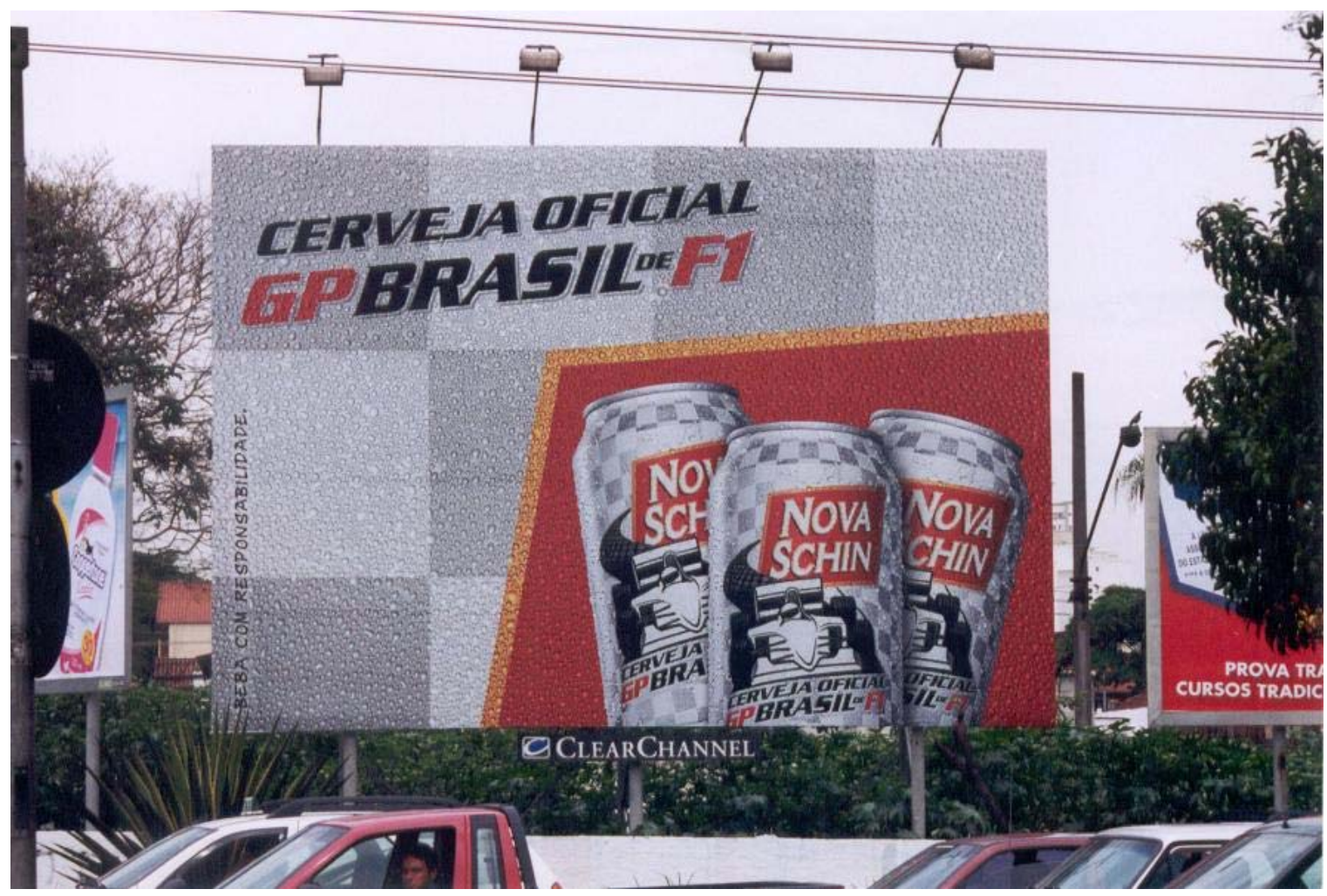

Figura 13 - Bridgestone, fabricante de pneus e patrocinadora das equipes Ferrari, evidenciou a conquista de seis títulos mundiais até 2004 anunciando a "paixão pela excelência".

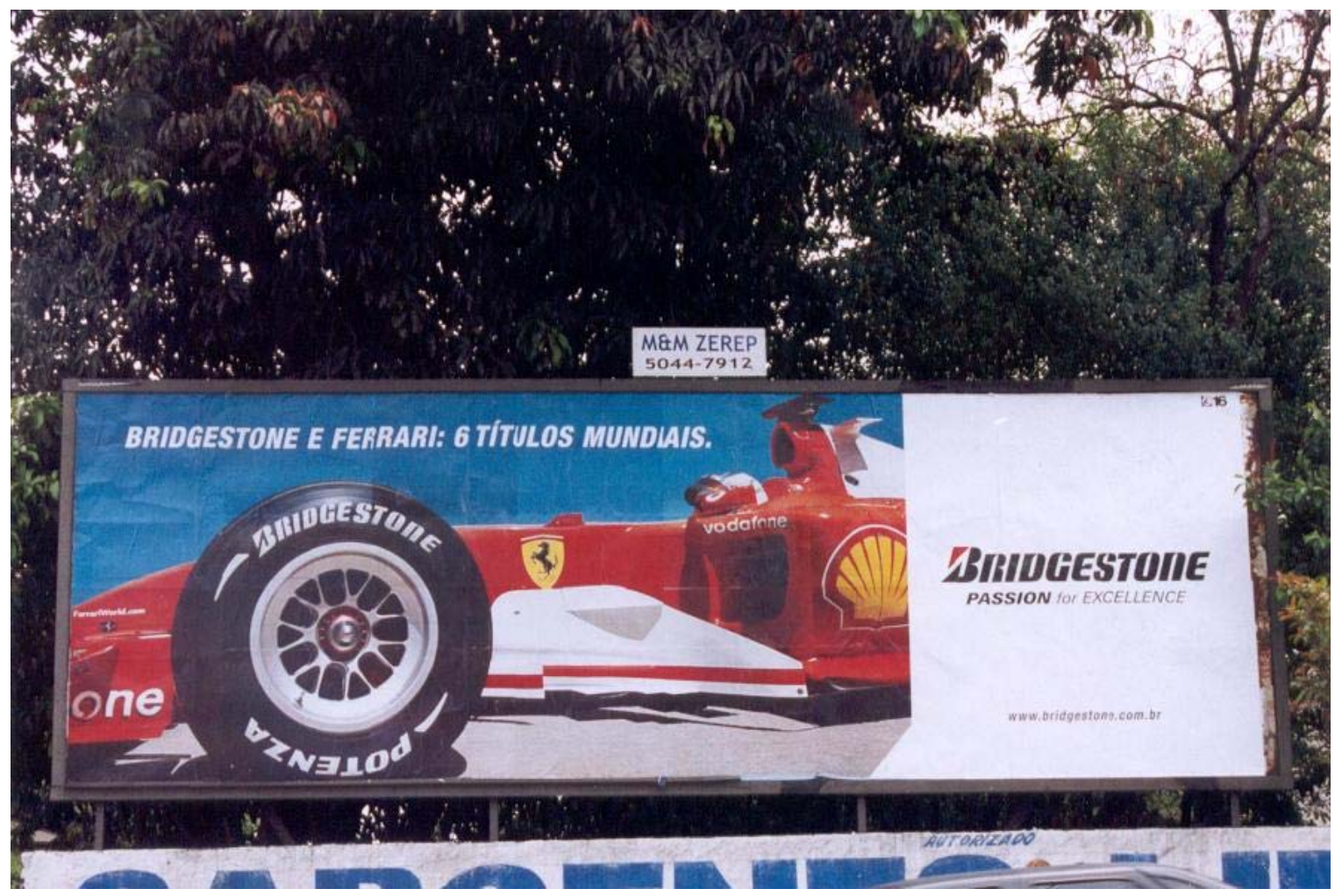

Figura 14 - A Petrobrás, que forneceu o combustível para a equipe BMW Williams, estabeleceu analogia de seu produto com a energia dos pilotos. 


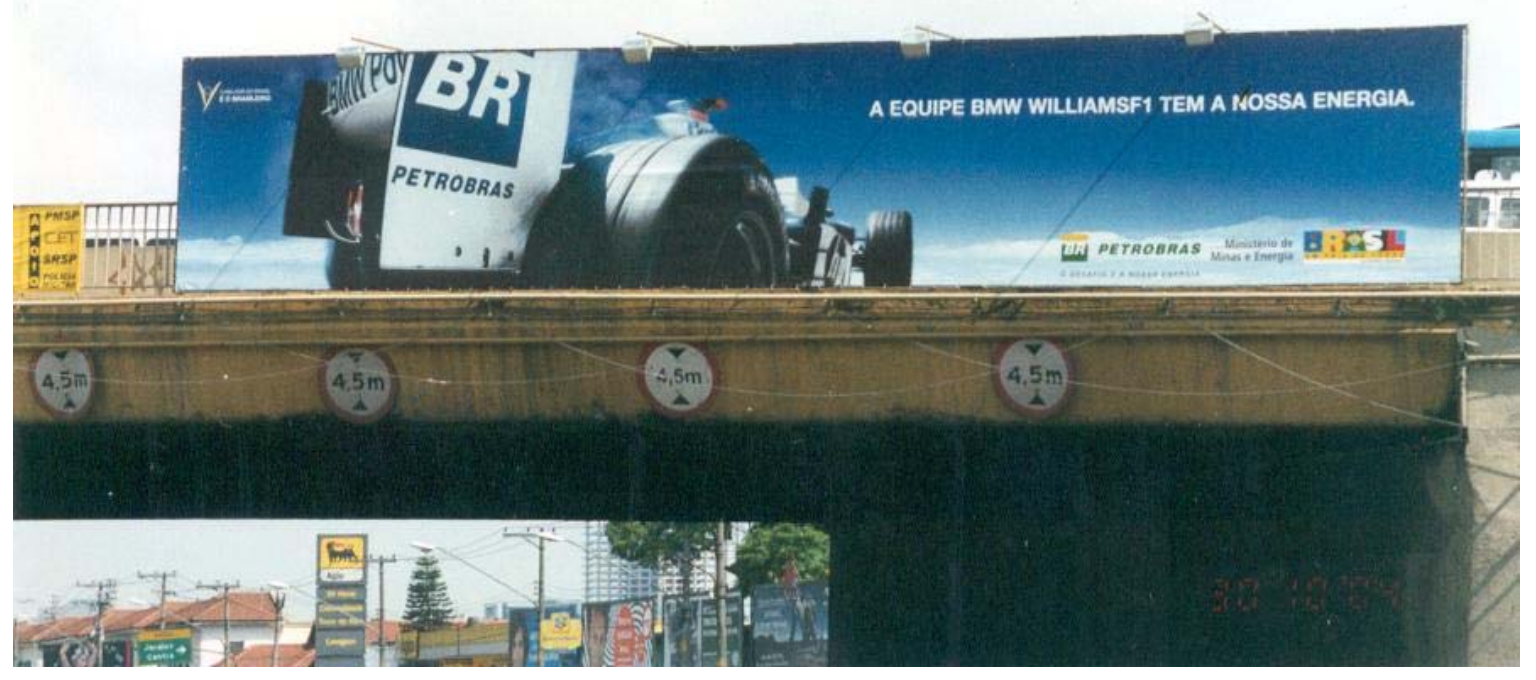

Figura 15 - Os postos da rede Shell divulgaram concursos de prêmios Ferrari a quem abastecesse no local, o que justifica-se pelo apoio da Shell às equipes da Ferrari que participavam da Fórmula 1 de 2004.

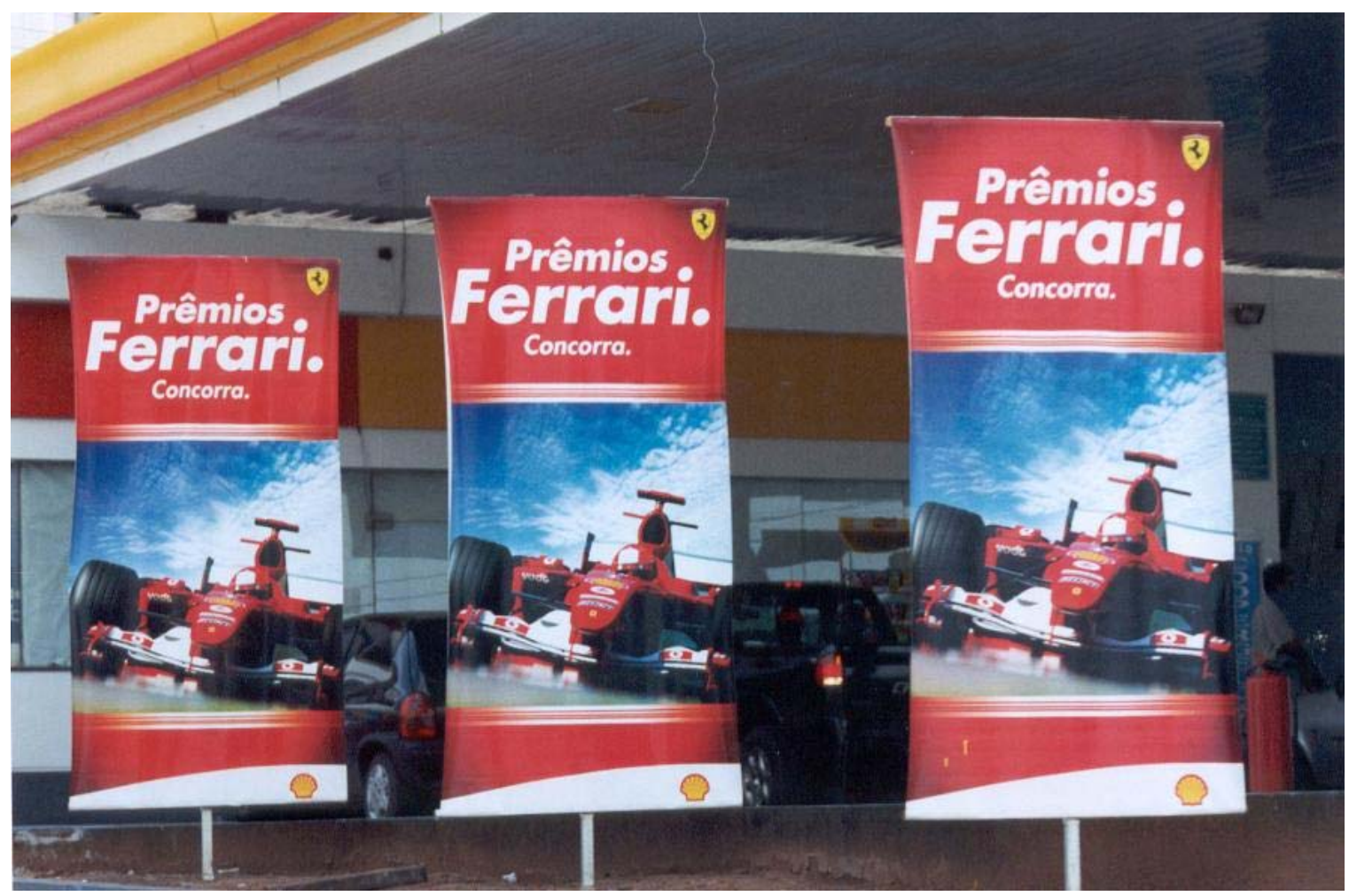

Figura 16 - O combustível diferenciado da Shell, Shell V-Power, é colocado como a gasolina campeã da Fórmula 1 pelo êxito das equipes patrocinadas 


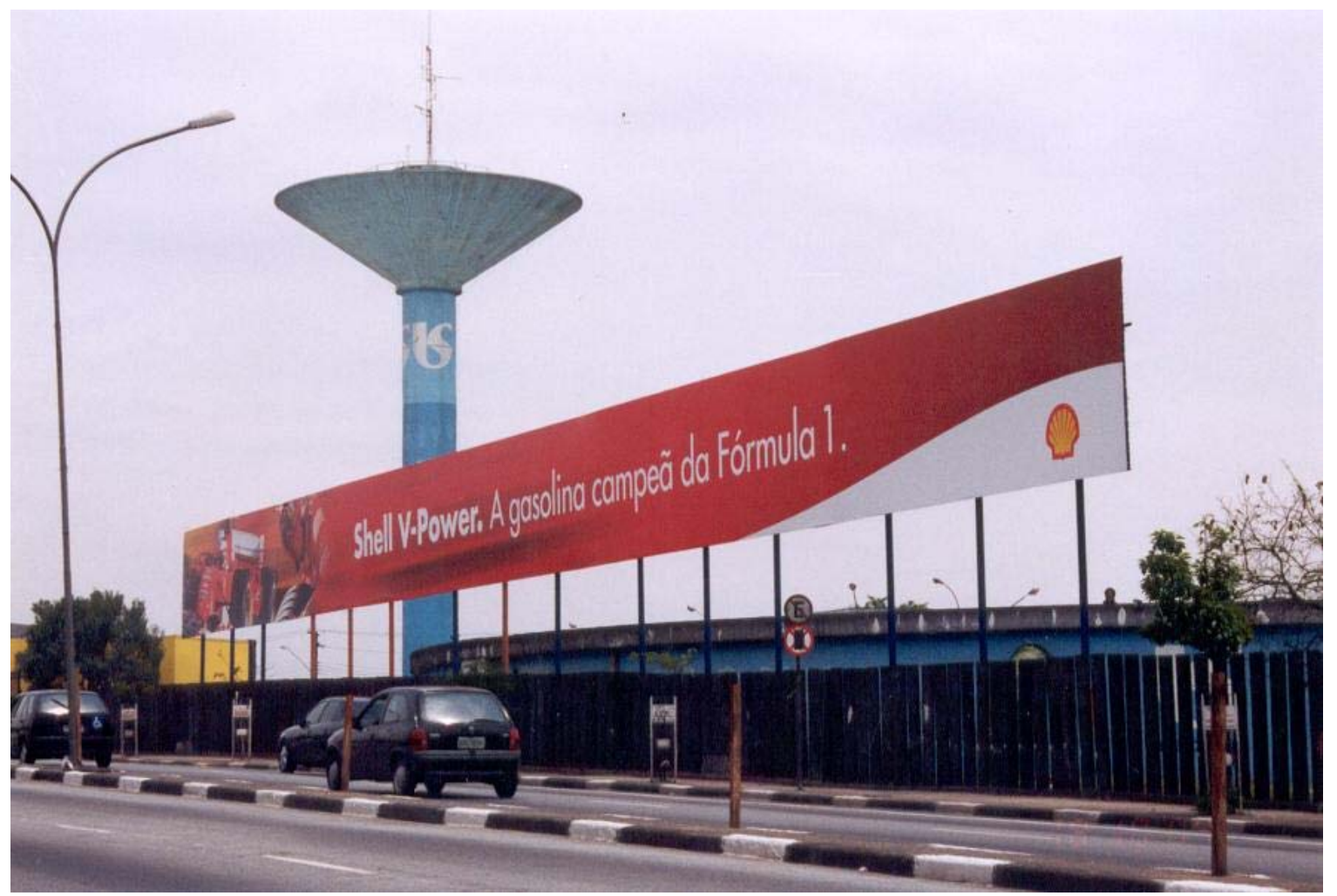

Figura 17 - A empresa DHL, parceira global da Fórmula 1, ligada ao trabalho de logística oficial, evidenciava a velocidade de seu negócio, destacando as cores da empresa na Fórmula 1 através da bandeira quadriculada, o que mostra a participação da empresa na vitória dos competidores

A grande maioria dos recursos financeiros destinados às equipes de corridas de automóveis provém das indústrias de tabaco que utilizam a Fórmula 1 como estratégia de marketing para a divulgação de seus produtos e marcas, patrocinando as equipes e pilotos que participam das competições. Em 2003, cinco equipes tinham o patrocínio de marcas de cigarro e competiam exibindo os logotipos: Ferrari (Malboro), McLaren (Nest), Renault (Mild Seven), Bar (Lucky Strike) e Jordan (Benson \& Edges). Conforme divulgado pelo jornal O Estado de São Paulo (2004), a Ferrari tinha quase um terço do orçamento anual (US\$ 420 milhões) financiado por uma marca de cigarro.

Uma grande polêmica em torno da publicidade do tabaco marcou o ano de 2003, ocupando a maioria dos jornais de grande circulação no Brasil, pois era um assunto de âmbito internacional com repercussões também para o país. 0 problema surgiu porque vários países anteciparam para o final de 2005 o banimento da propaganda de cigarros dos eventos esportivos quando, de fato, a OMS - Organização Mundial da Saúde estipulava como prazo o final de 2006. Conforme Seixas e Mariante (2003e), a Comissão Européia, assim como os 
Estados Unidos e a Austrália, decidiram antecipar o fim da publicidade tabagista para julho de 2005.

Como esclareceram Seixas e Mariante (2004e), a FIA estava programado para outubro de 2006 e as equipes utilizaram essa data como parâmetro para estabelecer os contratos com as empresas de tabaco. A FIA, conforme Ishikawa (2003k) pretendia entrar com uma ação na justiça da Europa contra a decisão da União Européia, numa tentativa de reestabelecer a data original, pois todas as ações e contratos da categoria haviam sido acordados com base em 2006 e a antecipação da lei provocaria grandes prejuízos. Essa data ficou acertada depois de muitas discussões da FIA com a União Européia e com a OMS - Organização Mundial da Saúde. A propaganda de tabaco, que passaria a ser proibida nos eventos de massa, era uma determinação que, segundo o jornal O Estado de São Paulo (2004), valeria também para os países que não faziam parte da União Européia, mas detinham direitos televisivos da competição.

A antecipação da data de 2006 para 2005 trouxe repercussões para todas as etapas da Fórmula 1 já que a FIA resolveu realizar a Fórmula 1 nos países em que a lei antitabagista fosse mais branda. Como mostram Seixas e Mariante (2004e), a Bélgica perdeu o Grande Prêmio depois de ter aprovado uma lei antitabagista que englobava a Fórmula 1. A Áustria caminhava para uma mesma situação na temporada de 2004 e, à FIA restava considerar a China, Bahrein, Rússia e Líbano por serem países mais tolerantes. A Bélgica, mesmo tendo o melhor circuito da Fórmula 1, o Spa-Francorchamps, perdeu a oportunidade de sediar o evento, que só voltou ao calendário depois que a legislação local foi alterada. Segundo declarações do Presidente da FIA, registradas por Seixas e Mariante (2004e), "quando o banimento é imposto em algum lugar do mundo, a tendência é buscar outros lugares para promover as corridas". No Canadá, enquanto não se adotaram mudanças na legislação local, como explicou Seixas (2003a), a solução encontrada pelos organizadores da Fórmula 1 para manter a corrida no país foi acertar uma contrapartida para os times que ainda corriam com marcas de cigarro; os promotores providenciaram uma compensação financeira para a McLaren, Ferrari, Jordan, Bar e Renault que puderam exibir os logotipos de seus patrocinadores. Como menciona Ishikawa 
(2003q), a indenização foi de cerca de U\$ 2 milhões para cada uma das cinco equipes.

No Brasil, uma lei federal, sancionada no final de 2000, provocou problemas em 2003, tanto para os organizadores da Fórmula 1 como para a Prefeitura Municipal de São Paulo. A lei 10.167 proibia, a partir do dia $1^{\circ}$. de janeiro de 2003, a veiculação de publicidade de cigarros em atividades esportivas e propaganda em estádios, pistas ou locais semelhantes utilizados para competições. O contrato com vigência até 2004, havia sido firmado em 1999, antes, portanto, de promulgada a lei, mas era um argumento insuficiente para restringir a publicidade do tabaco. A Prefeitura, como explicou Andrade (2003) havia investido $R \$ 7$ milhões apenas nas novas obras no autódromo e pairou o temor de que a prova não pudesse ser realizada. Além da Prefeitura de São Paulo, a Secretaria Municipal de Esportes e o Ministério dos Esportes se empenharam em levar o assunto à Presidência da República para tomar medidas que garantissem não apenas a realização da Fórmula 1 no Brasil, mas o Grande Prêmio de Motociclismo, em Jacarepaguá, no Rio de Janeiro, que, da mesma forma, estava comprometido.

As restrições quanto à publicidade do tabaco no Brasil recebiam apoio e liderança de diversos segmentos da sociedade. O Ministério da Saúde, como mostraram Seixas, Mariante e Dantas (2003), assumia a postura do governo anterior pela continuação do radicalismo com o setor, fruto do recrudescimento da legislação antitabagista durante a gestão do ex-presidente Fernando Henrique Cardoso. A ANVISA - Agência Nacional de Vigilância Sanitária, em reunião com o Ministério da Saúde, chegou a estipular multas de $\mathrm{R} \$ 2$ milhões à Prefeitura de São Paulo, à Rede Globo e equipes e fabricantes de cigarro, punições que alcançariam R 20 milhões. Segundo Seixas e Mariante (2003a) a ANVISA, entretanto, negou-se a aplicar multas aos infratores, uma vez que mantinha a atual perspectiva do governo em não impedir a realização da Fórmula 1. A Sociedade de Cardiologia chegou a protocolar um protesto na ANVISA e uma outra ação, junto ao Tribunal Regional Federal, tentando obrigar as equipes a retirar as logomarcas dos seus patrocinadores. Procurava-se, então, uma solução que garantisse a Fórmula 1 no país sem enfraquecer a legislação antitabagista, reconhecida internacionalmente pelo rigor. 
Durante o período de impasse, conforme Seixas e Mariante (2003a), a CBA recomendou à Souza Cruz que a marca do cigarro fosse excluída dos carros de corrida, e a Rede Globo orientou jornalistas e técnicos a não focalizar as marcas de cigarro.

O presidente da República, como descreveu Bragon (2003) liberou a propaganda de cigarro, que foi acompanhado por muitas críticas por parte do Congresso. A Advocacia Geral da União emitiu parecer justificando a continuidade da propaganda sob o argumento de que o contrato internacional entre a organização da corrida e a Prefeitura de São Paulo foi firmado antes da lei. A Casa Civil avaliou as críticas relacionadas ao poder público municipal quanto à permissão de propaganda de marcas de cigarro considerando que seria pior perder o evento. Esse fato poderia ser negativo para a divulgação da imagem do país no exterior pela quebra de contrato. Como resultado da discussão nas instâncias do governo acatou-se a sugestão do Ministério da Saúde, que obrigava todos os envolvidos a colocar advertências antifumo, não apenas durante as transmissões, mas também no próprio circuito de Interlagos, sendo que nesse foi completamente banida (Figura 18). A Medida Provisória 118/2003 representava uma adequação para manter a prova na cidade de São Paulo e, também, o espírito da lei antitabagista através das ressalvas quanto aos males provocados pelo fumo.

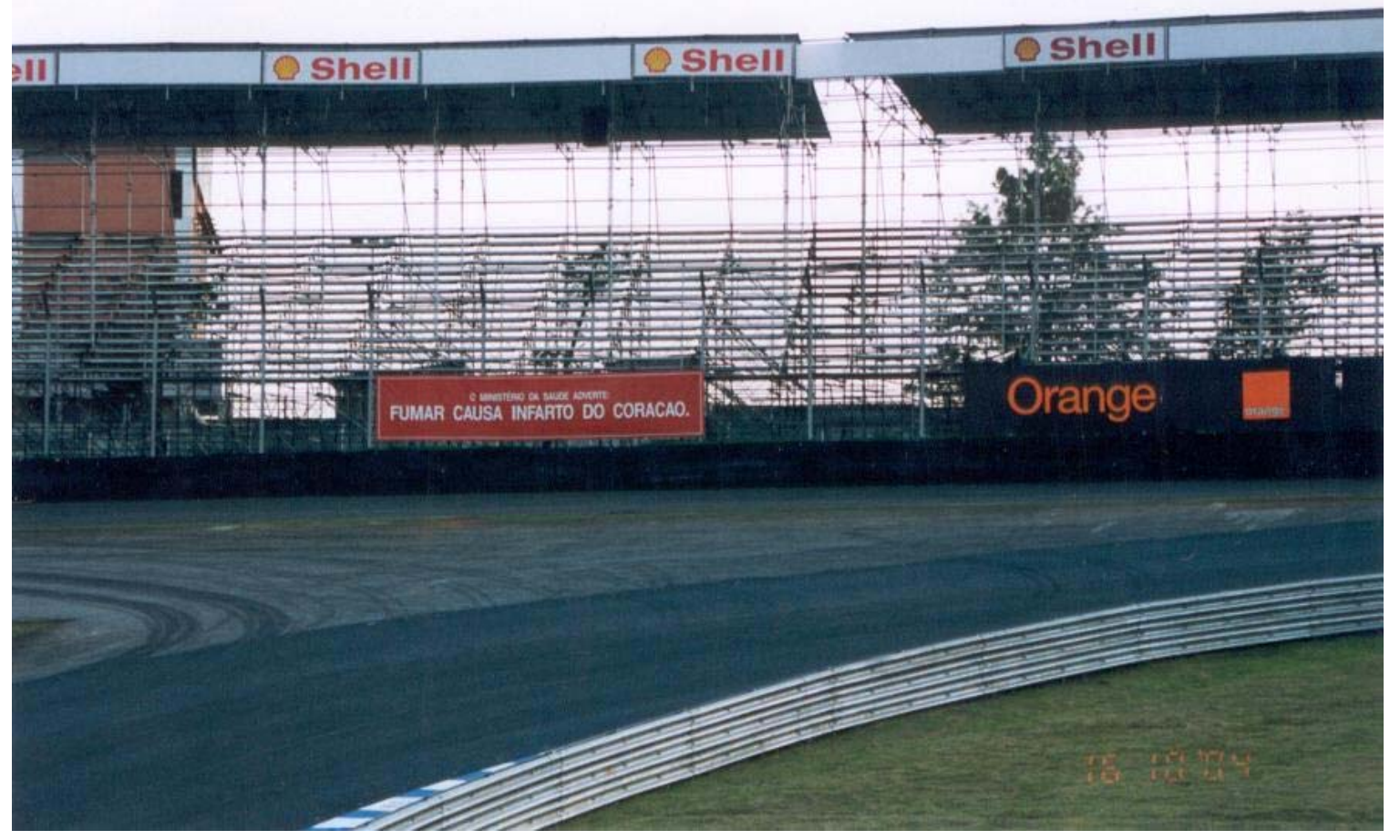

Figura 18 - Advertência antifumo, uma medida do Ministério da Saúde, no Autódromo de Interlagos (2004). 
A suspensão do efeito da lei antitabagista ficou condicionada, então, à veiculação gratuita, pelas emissoras de TV durante a transmissão do evento, de mensagens sobre os malefícios do fumo. A Rede Globo foi obrigada a acatar a lei e arcou com o ônus ao ceder gratuitamente espaço publicitário para o Ministério da Saúde, antes, durante e depois de cada corrida. Como observaram Seixas e Mariante (2003d), haveria um intervalo de, no mínimo 30 segundos, antes e depois das transmissões, além de mensagens verbais ou escritas a cada 15 minutos. As vinhetas seriam mantidas em todas as transmissões de corridas de Fórmula 1 que tivessem publicidade tabagista, a não ser a da Inglaterra e da França onde estavam proibidas as marcas de cigarro. Em nenhum outro lugar do mundo havia transmissões com avisos contra o cigarro, apenas no Brasil.

A mencionada Medida Provisória suspendeu até julho de 2005 o efeito da lei, tendo sido uma decisão do governo brasileiro elogiada pelo presidente da FOM - Formula One Management, que não poderia obrigar as equipes a correr sem os nomes dos patrocinadores. A prova, segundo Andrade (2003), seria cancelada e o Brasil perderia a vaga no calendário. A medida beneficiou, também, o motociclismo e teria, igualmente, importância para outras modalidades igualmente.

A discussão internacional em torno do tema continuou. Conforme Ishikawa (2003i), as entidades esportivas, não só a FIA, como também a FIFA Federação Internacional de Futebol e o COI - Comitê Olímpico Internacional trabalhavam em conjunto para emitir um documento que foi apresentado aos chefes de governo do bloco econômico europeu solicitando atenção às recomendações da OMS que propôs, desde o início, como data limite o final de 2006.

Por parte da FIA, como resultado da antecipação da União Européia, começou a se efetivar, conforme Cunha (2004) a ameaça de não mais se realizarem corridas nos países europeus, com exceção da França e da Inglaterra, onde haviam sido realizados eventos sem o patrocínio de marcas de cigarro. A Áustria deixou de participar das corridas a partir da temporada de 2005, e a FIA começou a empreender tentativas para levar o Grande Prêmio aos países da Ásia e do Oriente Médio, menos rigorosos em relação ao tabaco. Austrália, Alemanha e Estados Unidos, que elaboraram medidas específicas para receber a corrida continuaram no calendário automobilístico. Outras opções 
da FIA eram a Índia, México e Egito. Essa ampliação do mercado da Fórmula 1 é um exemplo de efeitos derivados de restrições governamentais. Segundo o Presidente da FIA, as equipes foram forçadas a procurar, em 2005 e 2006, eventos fora da Europa para cumprir os contratos de patrocínio.

Concluindo essa análise, deve-se ressaltar que, embora existam outras questões, relacionadas ao patrocínio de equipes, essa foi escolhida pela sua relevância para a Fórmula 1 em São Paulo. Trata-se, na verdade, de um assunto de interesse internacional que, em virtude de sua natureza circunstancial, política e de saúde, propagou-se por vários países e alcançou o Brasil. Eventos como a Fórmula 1 foram atingidos pelas medidas restritivas à publicidade do tabaco, a maior fonte de recursos financeiros das equipes automobilísticas.

Atualmente, a publicidade de marcas de cigarros restringe-se aos veículos de corrida, não aparecendo, como era usual, por toda a extensão do circuito. Percebe-se, assim, que as medidas adotadas resultaram numa propaganda mais discreta e, portanto, menos ostensiva. 


\subsection{Oferta direta de produtos e serviços}

$\mathrm{Na}$ oferta direta de produtos e serviços foram incluídos desde estabelecimentos sofisticados, que atendem um público exigente e internacional, serviços especializados de estabelecimentos comerciais pertinentes ao automobilismo e escolas de pilotagem, até a oferta de produtos geralmente consumidos pelo público de baixa renda e o aluguel de varandas.

Ainda integrado ao marketing de marcas, produtos e serviços, os restaurantes e hotéis também aproveitam o evento para fazer o marketing de seus negócios. A propaganda, contudo, acontece de forma indireta, compondo o que se costuma chamar de marketing mínimo, que se caracteriza pelo pequeno ou nenhum investimento. Ao proporcionar cortesias aos pilotos e integrantes das equipes de Fórmula 1, esses prestadores de serviços podem, não só reforçar o seu conceito de alto padrão em atendimento como também podem garantir a divulgação do negócio nos meios de comunicação sem ter que empreender campanhas publicitárias. Isso porque os jornalistas, nacionais e, sobretudo, os internacionais acompanham a rotina de cada uma das equipes e, em suas reportagens, podem citar os lugares freqüentados. Uma simples menção é o suficiente para relacionar a fama das equipes de Fórmula 1 ao prestígio de hotéis e restaurantes. Essas pessoas são formadores de opinião e, como tal, vistas como referência pelo público sobre a qualidade de uma certa experiência.

O Hotel Transamérica, ou Transamérica São Paulo, é, usualmente, o meio de hospedagem utilizado pela maioria das equipes de Fórmula 1 e dos jornalistas internacionais quando estão em São Paulo, o que é considerado por todos como uma referência no que diz respeito ao nível de qualidade no atendimento do turismo esportivo internacional. É o primeiro hotel categoria 5 estrelas brasileiro que conquistou a certificação ISO-9000, atualmente ISO9001/2000 por ser o único resort metropolitano a dispor em um dos seus jardins um campo de mini-golfe, piscina, quadras de tênis e health club, além da cozinha, também conceituada de padrão internacional. Sua localização é conveniente para os pilotos e membros das equipes de Fórmula 1, que desembarcam no Aeroporto Internacional de Guarulhos, percorrem a rodovia Ayrton Senna em direção à Marginal Tietê e, posteriormente, a Marginal 
Pinheiros e permanecem numa região considerada como um dos principais centros de negócios da capital. A área onde está localizado o Hotel Transamérica é o ponto mais próximo possível do Autódromo de Interlagos onde existe infra-estrutura urbana mais adequada ao atendimento dessa categoria de cliente.

Os restaurantes paulistanos localizados no bairro dos Jardins, que atendem as equipes de Fórmula 1, destacam-se por serem sofisticados e badalados, pitorescos e tradicionais. $\mathrm{O}$ atendimento de celebridades do automobilismo internacional assegura notoriedade ao estabelecimento junto à imprensa e aos clientes usuais, que podem se equiparar aos pilotos em termos de padrão de consumo e, até mesmo, de estilo de vida, satisfazendo, deste modo, as necessidades de aceitação e prestígio.

Outro efeito decorrente da Fórmula 1 que transparece no entorno do autódromo José Carlos Pace é a oferta de serviços técnicos das escolas de pilotagem que, de certo modo, estão associadas às necessidades que algumas pessoas têm de serem aceitas no meio automobilístico, de enaltecer o ego e compartilhar o status de ser piloto.

Todas as escolas de pilotagem de automobilismo oferecem cursos para quem deseja ter a habilitação específica de piloto graduado de competição, o que é autorizado exclusivamente pela CBA. Essas escolas utilizam o autódromo constantemente para as aulas práticas de seus alunos e mantêm um trabalho especial junto a empresas dos diversos segmentos. Cada uma delas, no entanto, oferece diferenciais que mostram a amplitude do mundo automobilístico, a diversificação da prestação de serviços na área de educação no trânsito e a proximidade com o cotidiano da população paulistana. As três escolas de pilotagem lidam direta e constantemente com os usuários do autódromo e do kartódromo. Não há outro lugar em São Paulo onde se possa encontrar esse tipo de prestação de serviços (Figura 19).

A Alpie Racing School, fundada em 1987, é a escola mais recente. Além dos cursos de graduação em pilotagem de competição, tem como diferencial a disponibilização de um dinamômetro Bosch que é utilizado como ferramenta para auxiliar as equipes na otimização, tanto do motor quanto do câmbio do carro. É um tipo de serviço dirigido exclusivamente aos veículos de competição. 


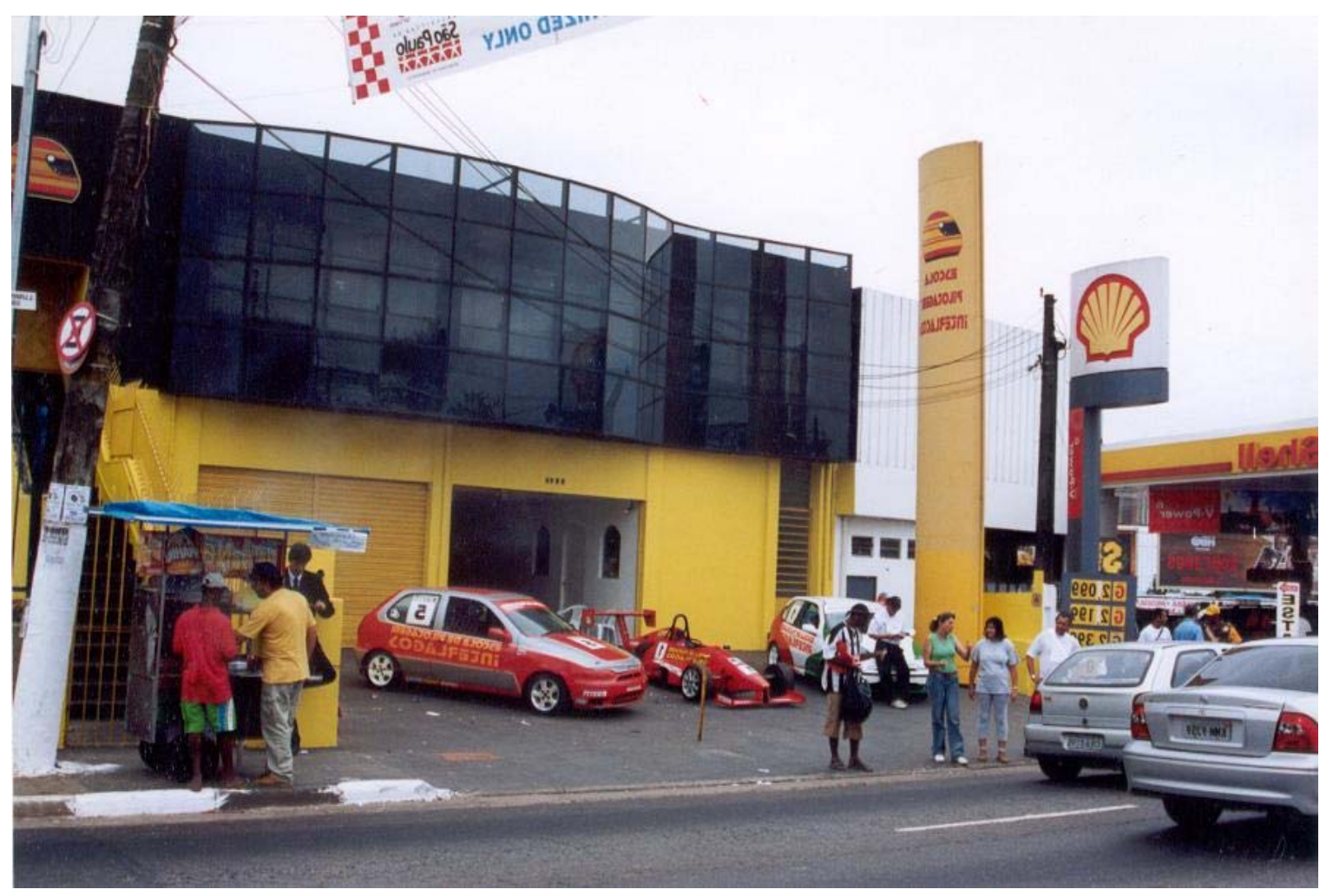

Figura 19 - Escola de Pilotagem Interlagos, uma das três escolas existentes no bairro de Interlagos, as únicas do gênero na capital paulista.

A Escola de Pilotagem Interlagos é a mais antiga e foi fundada, em 1967, por Emerson Fittipaldi e seu irmão Wilson. Já formaram 6 mil alunos e têm como principal objetivo otimizar a formação de novos pilotos e futuros campeões. Nos cursos de pilotagem de competição são ministradas noções e técnicas de contorno de curvas, da utilização completa do motor, a relação de marchas e freios, legislação esportiva, marketing esportivo e condicionamento físico. Dois cursos atendem demandas diferenciadas: Direção Defensiva e Proteção Executiva. O primeiro curso tem seu conteúdo baseado no National Safety Council USA que foi traduzido e adaptado para as necessidades brasileiras. Oferece regras de direção defensiva, respeitando o Código Nacional de Trânsito, além das técnicas de pilotagem, e é dirigido para motoristas do dia-a-dia. Já passaram pelo curso 7.500 pessoas. O segundo curso - Proteção Executiva compreende três fases: pilotagem, direção e técnicas e manobras evasivas. Voltada ainda para a atuação no esporte motorizado, essa escola abriga a Interlagos Eventos Esportivos, uma empresa que se propõe a planejar, implementar, coordenar e promover eventos esportivos. Através dela executa-se a montagem de infra-estrutura completa para a realização de competições automobilísticas, incluindo o aluguel do autódromo, a segurança nos portões e 
nos boxes, a organização esportiva no circuito, além da preparação dos boxes, da sinalização das pistas e da disponibilidade do resgate e serviço de atendimento médico.

O Centro de Pilotagem Roberto Manzini, também especializado na formação e aperfeiçoamento de pilotos e de motoristas, dedica-se a ministrar cursos e a oferecer condições para a prática do automobilismo nas pistas de Interlagos. Os cursos distinguem-se entre aqueles procurados por aficionados pelo automobilismo e aqueles destinados a pessoas que exercem algum tipo de ocupação profissional que exige aperfeiçoamento na direção de veículos. Para os adeptos do automobilismo, o curso "Piloto por 1 dia" oferece a oportunidade de sentir a emoção de dirigir um carro de competição no circuito de Interlagos. Piloto de teste é uma formação destinada a pilotos gabaritados para a realização de testes em novos produtos para a indústria automobilística e em componentes para a indústria de auto-peças, além de testes para revistas especializadas. Conforme o site da própria escola, as pessoas que optam pelos cursos de pilotagem despertaram para o prazer de pilotar um carro de competição por não se contentarem mais em, apenas, acompanhar, das arquibancadas, a disputa nas pistas. $\mathrm{O}$ aprimoramento na direção dos veículos também inclui as pessoas que têm dificuldade de adaptação no trânsito, ou que desejam adquirir atitudes preventivas de segurança pessoal. Neste particular, inserem-se as pessoas que são proprietárias de veículos blindados ou agentes de segurança que visam, especialmente, a direção preventiva e a integridade física em caso de roubo ou tentativa de seqüestro. Outra atuação desta escola refere-se a sua parceria com a empresa Porto Seguro. Aos assegurados, jovens entre 18 e 24 anos, a escola oferece cursos de um dia que inclui aulas nas dependências do autódromo. Essa iniciativa da seguradora foi tomada em relação a essa faixa etária, provavelmente, para conscientização e prevenção de acidentes de trânsito.

Outras atuações da escola são: assessoria para a realização de eventos nas instalações do autódromo, promoção e lançamento de produtos e testesdrive, e realização de eventos empresariais visando o treinamento de funcionários e a recepção de clientes e de fornecedores.

É elevado o nível de profissionalismo no âmbito esportivo desta escola. Dentre todas as escolas, é a única que mantém uma equipe que participa 
regularmente de quatro competições automobilísticas: a Copa Renault Clio, duas de Stock Car e a Mil Milhas Brasileiras.

Embora extrapole o âmbito desta pesquisa, que trata do automobilismo, convém mencionar que os efeitos da Fórmula 1 alcançam, também, as motocicletas. Apenas no bairro de Interlagos existem duas escolas de pilotagem de motocicletas que também utilizam o autódromo de Interlagos para aulas: a GPS Racing School Center e a Moto School. Essa última oferece aos alunos a possibilidade de participar de competições e eventos do motociclismo realizados no circuito de Interlagos, o que, de certo modo, reforça as idéias de compartilhamento do espaço real dos pilotos de Fórmula 1, estimulando a autoestima e o ego.

Outro efeito da presença do autódromo e do automobilismo, que se reflete também no motociclismo, é a presença de estabelecimentos de comércio voltados para esses ramos respondendo a necessidades de consumo. As lojas comerciais reúnem, em geral, serviços de oficina mecânica, pneus, alinhamento e balanceamento, peças e acessórios, e solda. Alguns estabelecimentos estendem esses serviços ao kart. Do total de onze lojas desse gênero existentes em São Paulo, oito deles localizam-se na zona sul da capital, sendo que cinco (ou $45 \%$ do total) situam-se nas imediações do autódromo. A área de concentração dessas empresas são as proximidades do portão $G$, entrada que oferece o melhor acesso ao kartódromo, na confluência das avenidas dos Jangadeiros com Jacinto Júlio. A movimentação em função do autódromo e das lojas contrasta com a tranqüilidade das ruas do bairro. Ao lado do portão $G$, profissionais especializados oferecem serviços inusitados, como é o caso da pintura personalizada de capacete.

A oferta de serviços no entorno do autódromo estende-se ao aluguel de varandas que expressa o desejo das pessoas de assistir ao vivo o evento, aproximando-se dos carros e dos pilotos. Essa oferta aparece na publicidade que acontece informalmente e que só percebida por aqueles que transitam pelas ruas adjacentes ao autódromo de Interlagos. Placas rústicas, pintadas à mão, sem nenhum capricho, passam mensagens afixadas nos postes, localizados em pontos estratégicos da vizinhança ou, até mesmo, no local que será alugado. Considerando que a área adjacente ao autódromo fica interditada pela CET, que impede a entrada de carros e pessoas, pode-se inferir que são os próprios 
moradores os usuários das varandas, mediante aluguel por tempo determinado pelo locatário.

Contrastando com a oferta de produtos e serviços sofisticados, já expostos, destaca-se no entorno do autódromo José Carlos Pace, a presença de numerosos ambulantes. Essa oferta caracteriza-se pela profusão, pela espontaneidade de alguns tipos e pela desorganização espacial.

Carrinhos, caixas de isopor, ou simplesmente rústicos balcões servem para apresentar as mercadorias, entre as quais se destacam aquelas de gosto popular (água e refrigerante, pipoca, batata frita, amendoim, bolachas, etc.), além de sorvetes de marcas famosas, ou não. Embora seja proibida a instalação de barraquinhas, centenas de pessoas encontram uma forma de vender seus produtos e algumas chegam a montar bancadas dentro dos jardins das casas próximas. Os ambulantes que, fora das competições trabalham em barraquinhas ou trailers, que são proibidos nesses momentos, têm por alternativa perambular carregando as caixas de isopor.

Bancas de artesanato com objetos de madeira focados no automobilismo, além de "flanelinhas" e guardadores de carros, completam a oferta direta de produtos e serviços mais consumidos, geralmente, por pessoas de baixa renda (Figuras 20, 21, 22 e 23). Esse fato denota a popularidade dos eventos automobilísticos, principalmente da Fórmula 1. Do mesmo modo pode ser entendida a cortesia de aparelhos de televisão aos clientes dos bares e restaurantes do entorno do autódromo (Figuras 24 e 25). A padaria Santo Antonio dispõe de grandes televisores, dentro e fora do estabelecimento e, seu movimento é tanto que o horário é estendido, passando a funcionar 24 horas entre a sexta-feira e o domingo da prova. Isso garante um faturamento pelo menos $50 \%$ maior que o normal (Jornal da Tarde, 2002). Paralelamente, os postos de gasolina adotaram essa prática para conquistar seus clientes, aqui de outra classe social.

Os fãs do automobilismo, portanto, não se restringem às classes mais ricas. É também do lado de fora do autódromo que pessoas simples manifestam a sua admiração pelo esporte. Os poucos espaços da avenida Interlagos, que permitiam ver uma parte do autódromo, são utilizados pelo público (Figuras 26, 27 e 28). 
Uma explicação se faz necessária. Considerando-se que o custo do ingresso parte de um valor elevado, exceto para estudantes e pessoas com necessidades especiais que pagam apenas $50 \%$, pode-se inferir que uma parcela desse público observado no entorno, não adentra ao autódromo para assistir à competição. A esse público, de um modo geral, está dirigida a oferta de produtos e serviços acima mencionados, assim como os aparelhos de televisão gentilmente oferecidos pelos comerciantes locais.

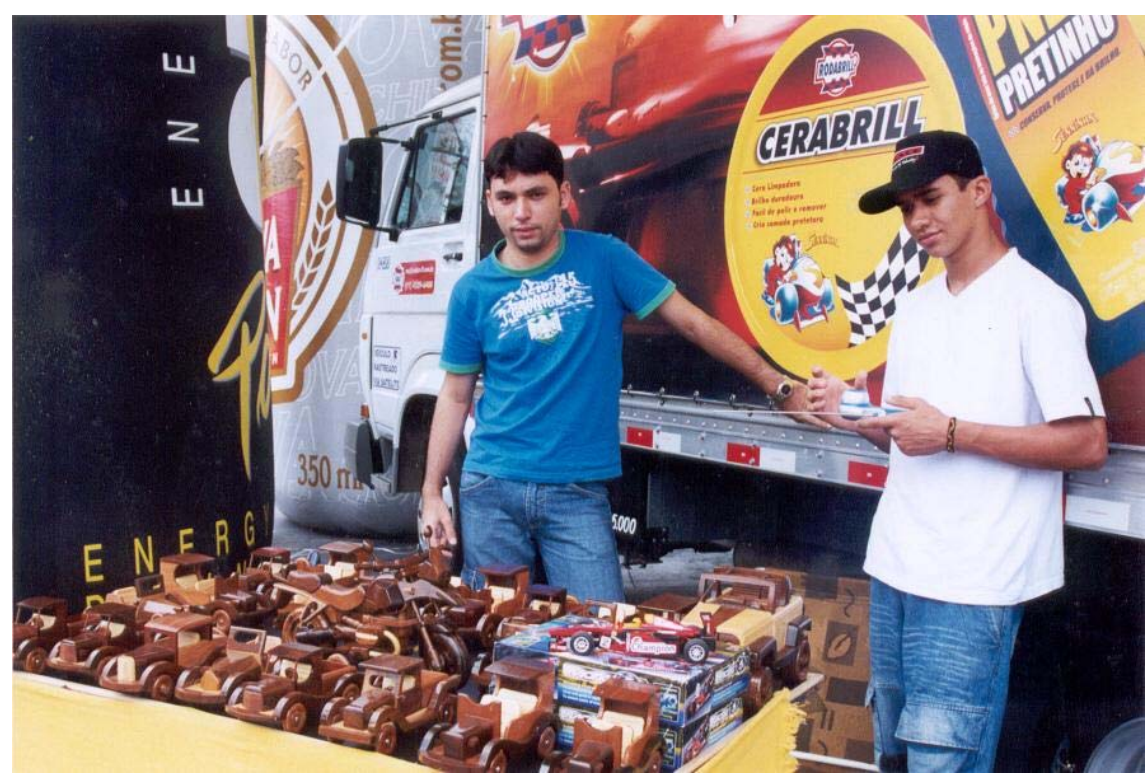

Figura 20 - Banca de artesanato em madeira localizada próximo à movimentação de bares e lanchonetes em frente ao autódromo.

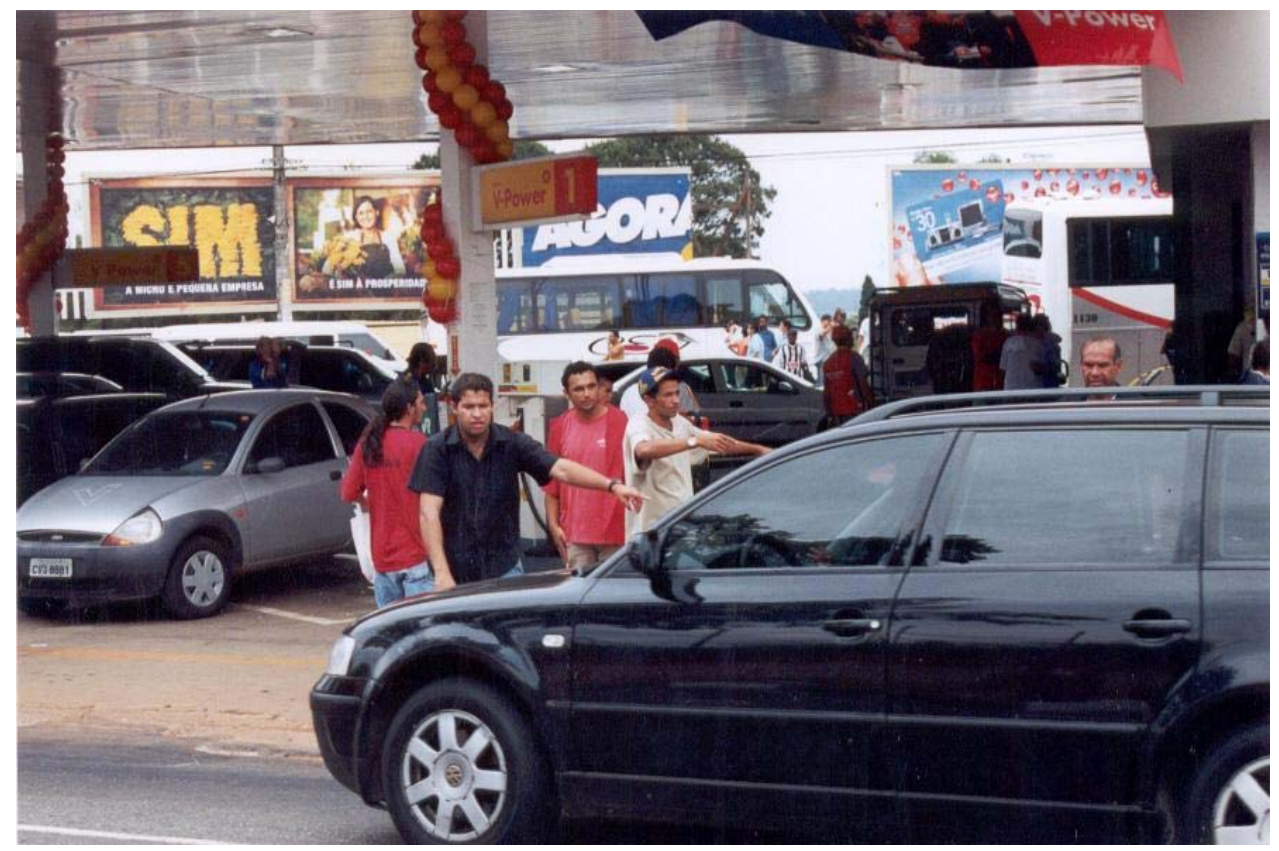

Figura 21 - "Flanelinhas" e guardadores de carros que todos os anos estão presentes nos arredores do autódromo de Interlagos. 

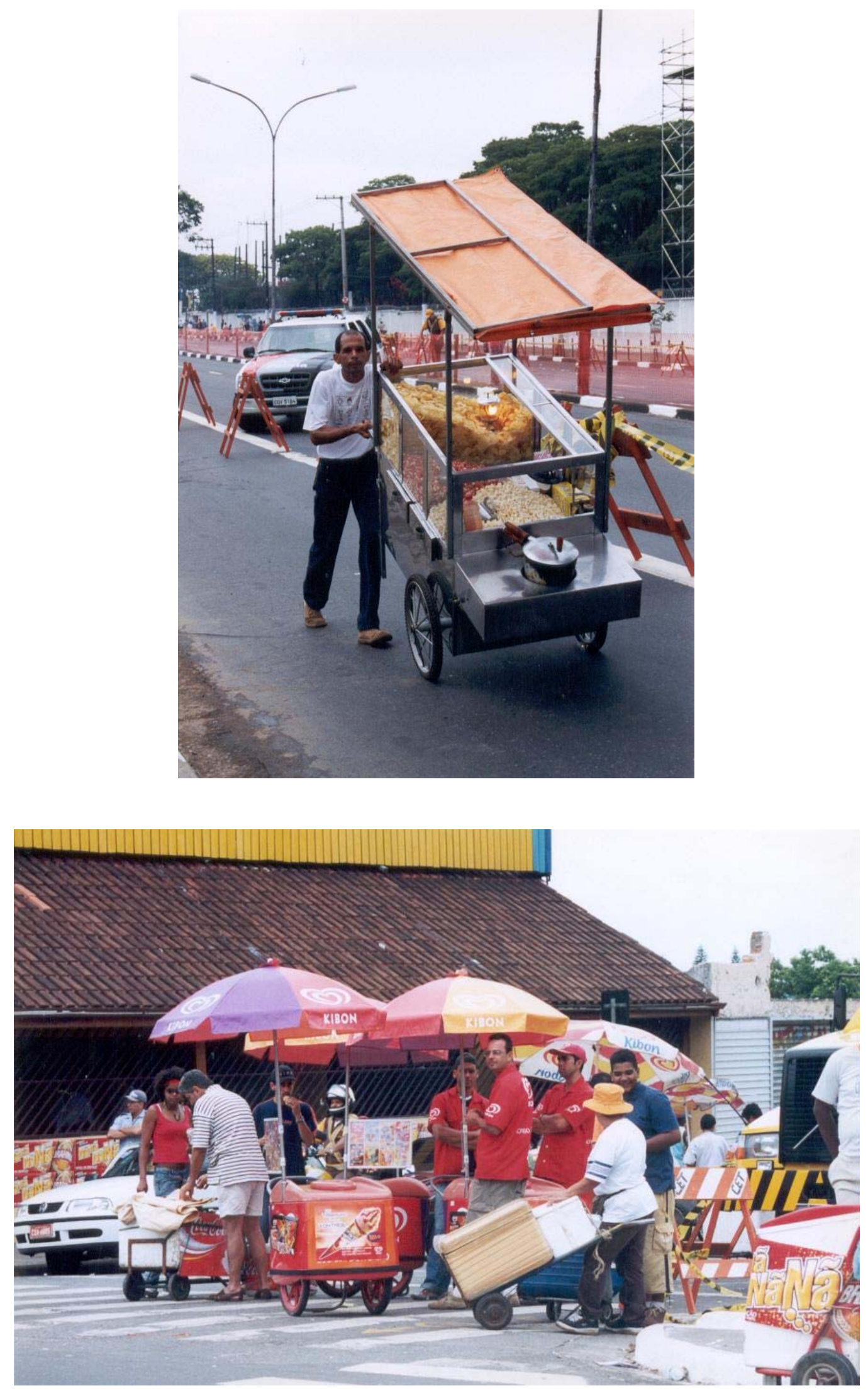

Figuras 22 e 23 - Ambulantes oferecem produtos consumidos, em geral, por pessoas de baixa renda. 

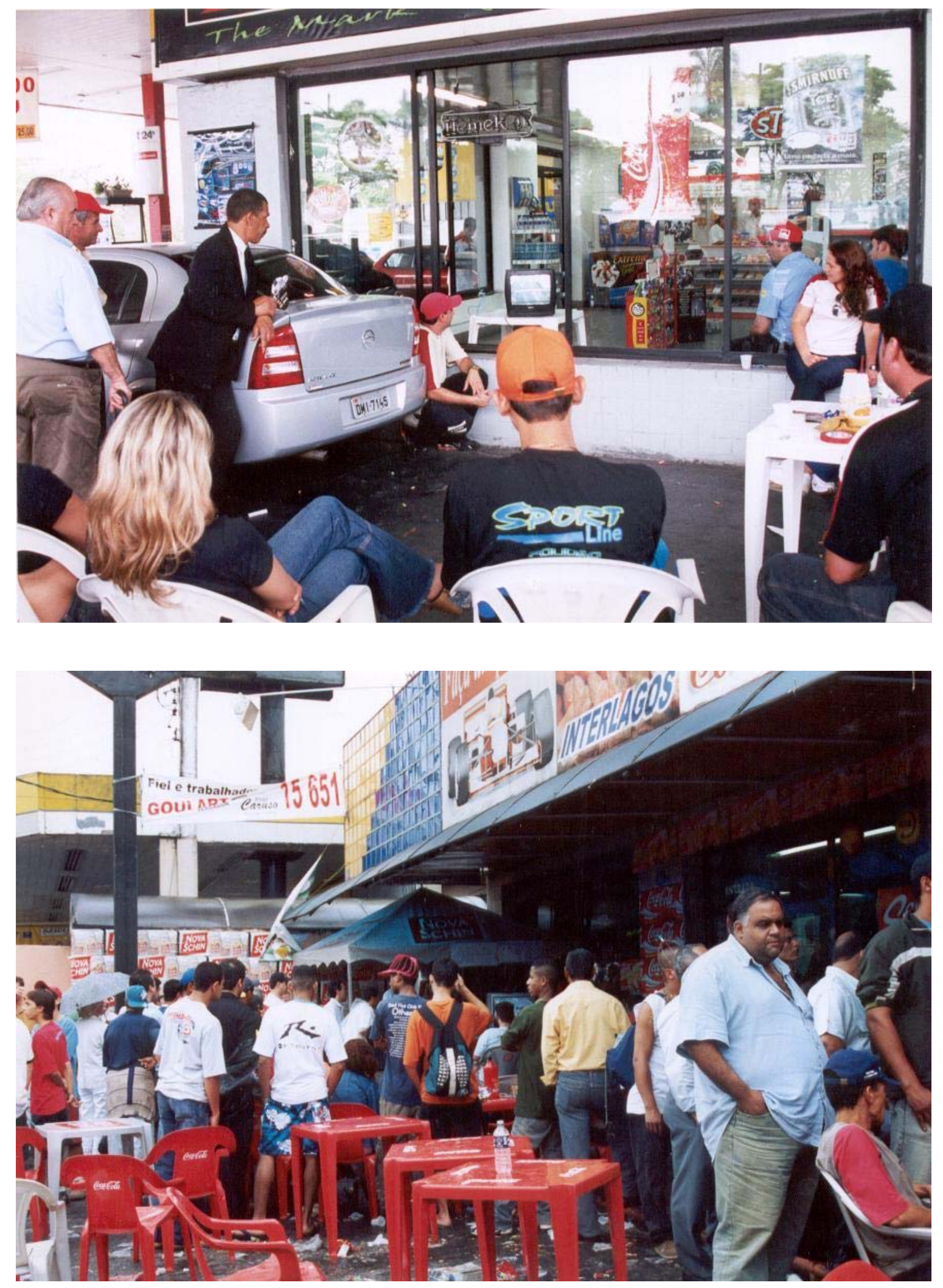

Figuras 24 e 25 - Disponibilidade de TV nos estabelecimentos comerciais oferecem à sua clientela a possibilidade de assistir à Fórmula 1. 


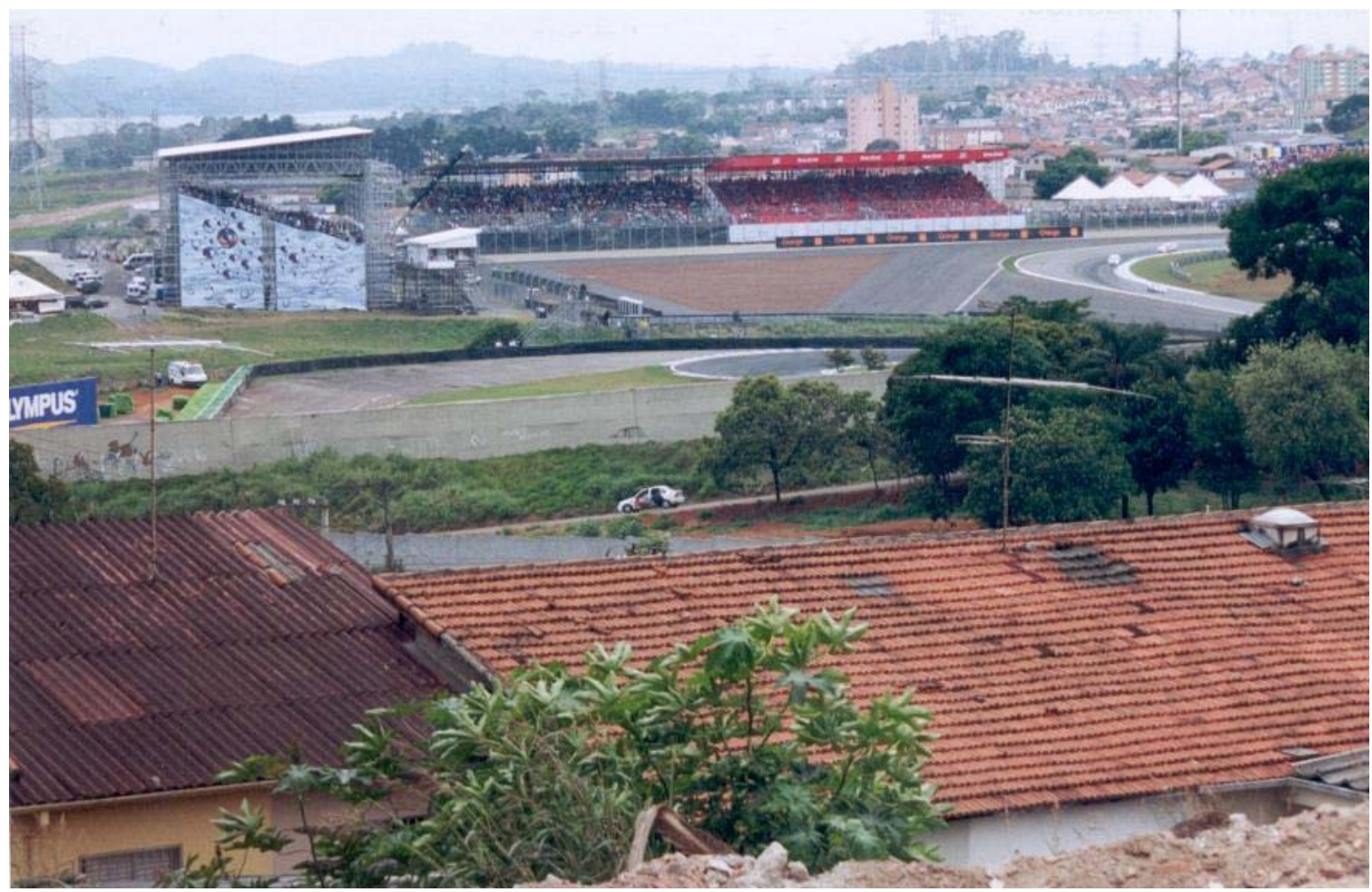

Figura 26 - Visão do circuito de Interlagos proporcionada por um dos poucos espaços ainda desocupados na avenida Interlagos, adjacente ao circuito.

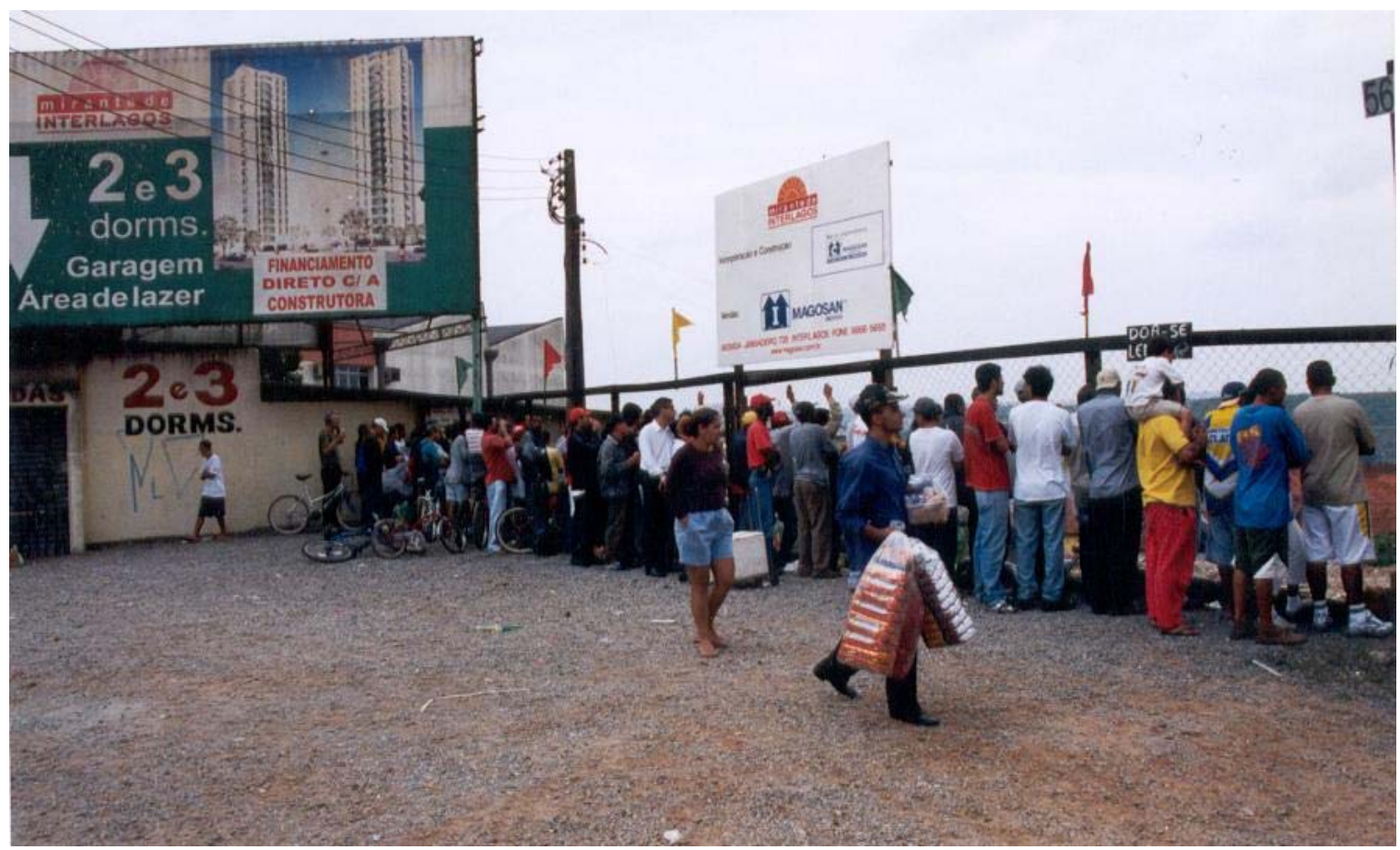

Figura 27 - Público que afluiu ao autódromo em razão da Fórmula 1 acompanhava o evento, externamente, em espaços ainda desocupados. 


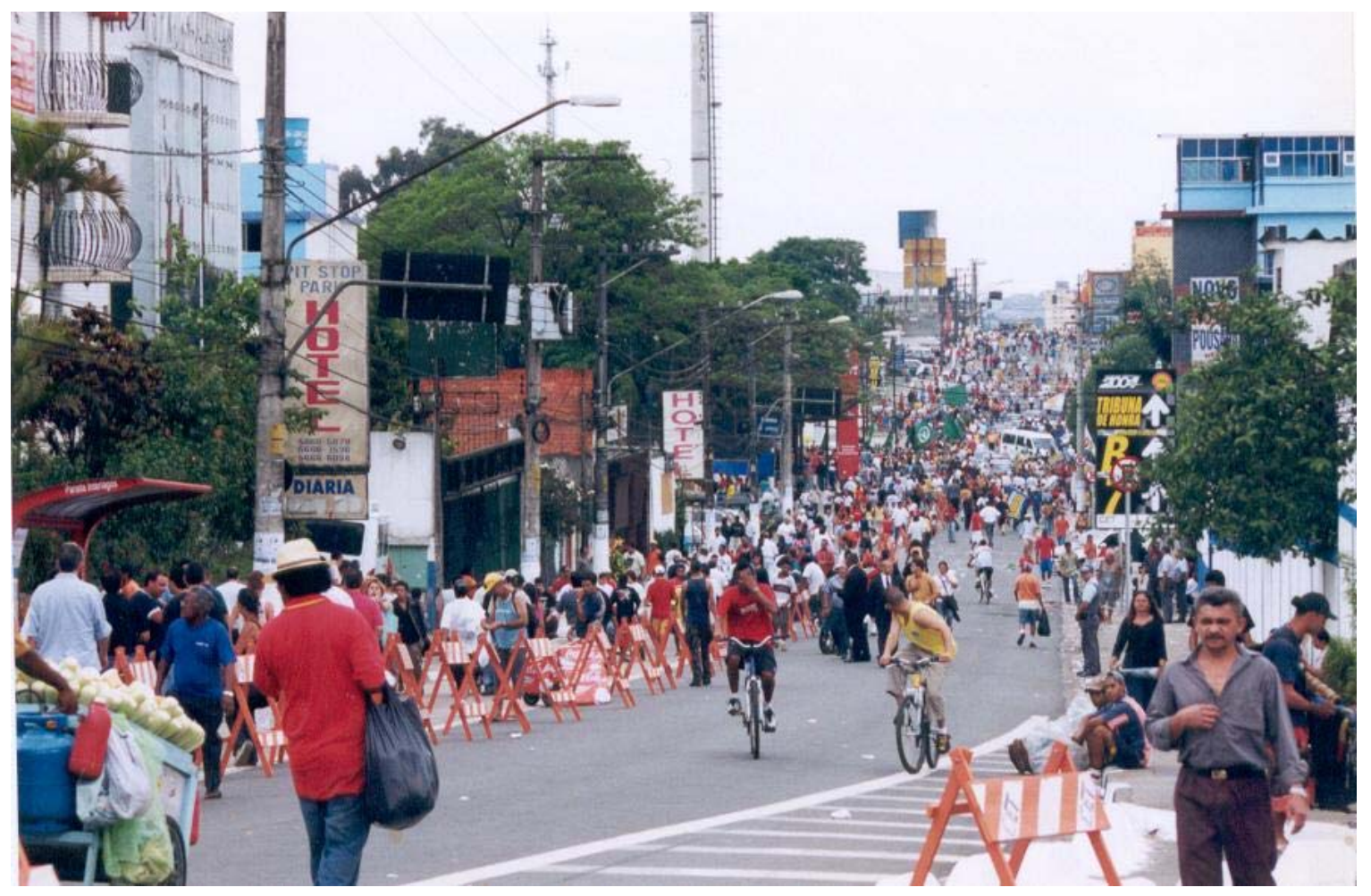

Figura 28 - Fãs do automobilismo que afluem ao autódromo mesmo sabendo que não têm acesso. 


\subsection{Lazer e entretenimento: o erotismo}

As opções de lazer e entretenimento divulgam serviços presentes na Fórmula 1, cujos efeitos repercutem no espaço urbano da cidade de São Paulo, especialmente no entorno do autódromo José Carlos Pace.

Das múltiplas possibilidades de lazer e entretenimento oferecidas pela cidade de São Paulo, uma delas se destaca em virtude da proliferação de material publicitário e mensagens que denigrem a imagem da capital paulista, estimulando o chamado turismo sexual ou turismo erótico. Intrigante, porém difícil de ser combatido, esse segmento pode ser explicado, como mostram Evans, Forsyth e Wooddell (2000), pela condição de pobreza da população e pela expansão dos investimentos estrangeiros, o que constitui a realidade de alguns países do Caribe e do Sudeste Asiático.

As viagens motivadas prioritariamente para experimentar sexo e erotismo, felizmente, não fazem parte do mercado turístico institucionalizado de São Paulo, como acontece nos países mencionados. O lazer e o entretenimento noturno existentes na capital, que estimula a prostituição, contribuem, assim como acontece em qualquer lugar, para propagar uma imagem negativa no exterior. Esse assunto deve ser visto com muita atenção e preocupação já que essa referência pode comprometer o pleno desenvolvimento de uma localidade turística, sobretudo quando se consideram os valores e a auto-estima da população.

Imagens e, sobretudo, mensagens, que representam o mais importante recurso da comunicação e do marketing são difundidos nos períodos de corridas automobilísticas. A análise de textos de jornais e a pesquisa de campo mostraram que, em São Paulo, há pessoas e, até mesmo empresas desse mercado informal atuando no momento das competições. Numa das edições do Grande Prêmio do Brasil de Fórmula 1, no final da década de 1990, um outdoor de proporções exageradas mencionava: "Na Espanha, as touradas; em Paris, a Torre Eifel e em São Paulo, o Café Photo". Esse estabelecimento divulgou tal mensagem em frente ao portão principal do autódromo, como se estivesse se auto-denominando a principal atração turística da cidade de São Paulo, assim 
como a tourada e a Torre Eifel, ou seja, algo conhecido que não pode deixar de ser visto.

Outro efeito do automobilismo no mercado do turismo sexual em São Paulo pôde ser inferido na meteria de LHM (1998) que, mostrando as opções de lazer de membros da Fórmula 1, coloca o seguinte título: "Carnes e mulheres fazem a fama". O jornalista explica que para boa parte dos membros da Fórmula 1, São Paulo significa asfalto ondulado, churrascaria e sexo.

No exterior, a revista da Benetton (Inglaterra), referindo-se ao Grande Prêmio de 1996, publicou um artigo que, apesar do humor do humor, desenhava São Paulo como uma cidade infecta, onde, à mesa, se serviam carnes de animais estranhos. A TV alemã, em 1997, ao anunciar a corrida de Fórmula 1 em São Paulo, exibia carros e traseiros femininos. Numa declaração de um turista estrangeiro, a fama da cidade, nesse ponto, só perdia para a de Budapeste, um dos mais famosos centros de prostituição do Leste europeu.

A divulgação de imagens negativas comparando as mulheres brasileiras aos carros mais velozes da Fórmula 1 pode ser exemplificada por este anúncio: "Venha conhecer as melhores garotas do Brasil e conferir as máquinas mais quentes em exibição". Conforme Seixas (1998), essa frase chegou a constar do programa oficial da corrida e, além disso, com versão em inglês. A reportagem "Turismo sexual invade até o programa oficial do GP" mostrava que boates e casas noturnas de São Paulo ocupavam espaço na folheteria distribuída durante a Fórmula 1, como se naturalmente fizesse parte do evento, algo como um entretenimento complementar, restando, apenas para isso, serem incluídas na programação oficial.

Em 1998, a propaganda de casas noturnas estava mais ostensiva doque em anos anteriores. Seixas (1998) percebeu isso ao presenciar que o mercado do turismo sexual abordava, diretamente, todos os estrangeiros que passavam pelos portões do autódromo de Interlagos. Engenheiros, técnicos e mecânicos da Fórmula 1, quando no Brasil, eram assediados ao terminar a montagem dos boxes das equipes. Na quarta-feira que antecede o evento, é intensificada a distribuição de folhetos por garotas, especialmente contratadas, para entregálos, pessoalmente e com simpatia, aos potenciais clientes. Conforme registrou Seixas (1998), um verdadeiro plantão costuma ser feito em frente ao principal acesso do autódromo do estacionamento interno: "Vestindo minissaias, 
distribuem sorrisos e panfletos aos ocupantes dos carros que saem do circuito". (...) "Os alvos preferidos para a abordagem são as kombis cedidas para a prova, que transportam engenheiros, mecânicos e o pessoal de apoio - em grande parte ingleses, italianos e franceses" (Seixas, 1998).

Nenhuma outra opção de lazer da capital é tão direta e ostensivamente dirigida ao seu público-alvo como o que ocorre em relação ao entretenimento das boates e casas noturnas junto aos turistas e visitantes da Fórmula 1. Em 2004, a fachada da drogaria Délia, localizada defronte do autódromo, cedeu o espaço de identificação da empresa para ser totalmente ocupado. Uma faixa, com cerca de 10 metros de comprimento, anunciava a boate Romanza, incluindo mensagem em inglês e o site da internet. Nela lia-se: "Você sabe o que acontece depois do pódium? Venha descobrir" (Figuras 29 e 30).

$\mathrm{Na}$ folheteria, as boates ofereciam atrações usuais denotando influência de programas de maior audiência da TV brasileira aos domingos, daquela época, como "banheira do Gugu", exibida pelo SBT, além de ofertas sedutoras, incluindo shows de striptease, sushi erótico, luta de mulheres no gel, piscinas com hidromassagem, sex shops e a oportunidade de levar alguma garota de programa para o hotel (Seixas, 1998). 

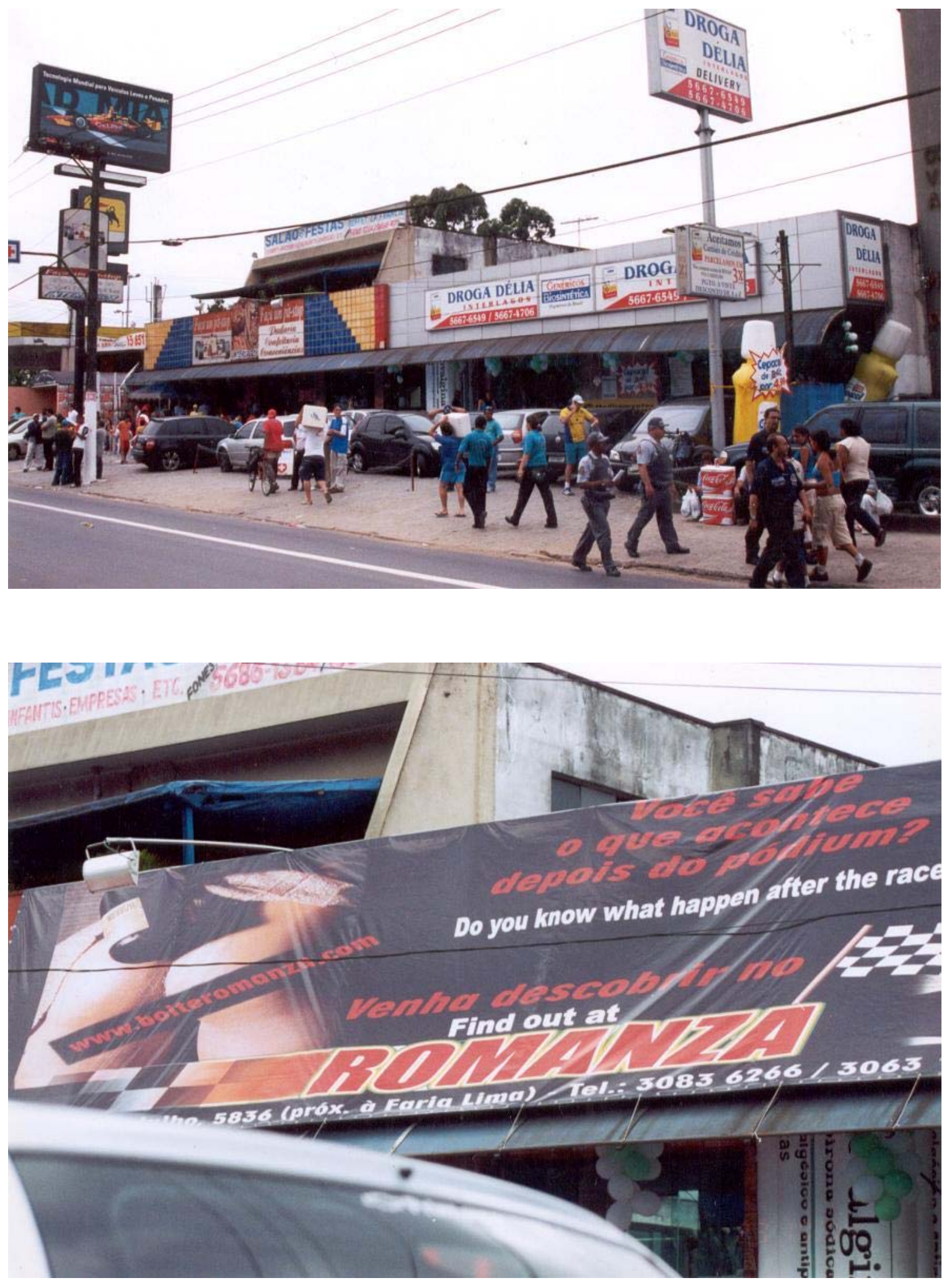

Figuras 29 e 30 - Fachada de uma drogaria que foi utilizada, em 2004, de forma oportunista, durante a Fórmula 1, divulgando apelo erótico para o entretenimento dos visitantes. 
Numa entrevista realizada por Seixas (1998), uma garota de programa de uma boate, normalmente considerada como anfitriã da casa, declarou que cerca de 200 pessoas ligadas ao GP freqüentavam o local, todas as noites, desde a quarta-feira. Segundo ela, eram membros de equipes e jornalistas estrangeiros de vários países. O idioma, entretanto, não se tornou uma barreira e a dificuldade de se comunicar não era um empecilho, mas se tornara uma diversão. Nessa boate, também foram feitas reservadas antecipadas de mesas e de garotas para uma das equipes (Seixas, 1998).

Mas não foi apenas no final da década de 1990 que o turismo sexual se pronunciou tanto. Em 2003, a manchete "GP gera corrida ao sexo em São Paulo" mostrava que os integrantes de equipes e espectadores de prova são consumidores que aquecem o ramo da prostituição de alto luxo. Não é apenas a economia da cidade que é estimulada pela passagem da $F 1$, mas há o incremento da prostituição de alto luxo que, nas palavras dos seus empresários, diziam viver o melhor momento do ano graças ao Grande Prêmio; comentavam, inclusive, que o "S" da curva do Senna em Interlagos também representava o "S" de sexo em São Paulo. Por analogia, pode-se lembrar da tônica do desenvolvimento do turismo de massa cujo slogan enfatizava os 3 "s" de sea, sun and sex, que foi tão criticado e combatido pelos especialistas que estudam o turismo.

O luxuoso mundo de carros possantes e pilotos habilidosos fazem quase dobrar a clientela das casas noturnas durante o período do evento, seja ela formada por integrantes das equipes estrangeiras ou por aficionados visitantes, que chegam do interior ou de outro estado (Ohata; Ribeiro, 2003). Assim, se todos os caminhos no fim-de-semana do evento levam a Interlagos, porque existe uma operação de sinalização especial para a Fórmula 1, esses mesmos caminhos ficam repletos de outdoors apelativos, indicando os pontos de encontro mais sofisticados e famosos de São Paulo para o entretenimento em casas noturnas.

A divulgação do entretenimento noturno nos períodos de corridas era usual na cidade de São Paulo e estava nas principais ruas para suscitar o desejo de passar uma "noite de $1^{\circ}$. Mundo" na Café Milenium, "dar asas à imaginação" na casa Bahamas ou "uma noite com mais prazer" na Café Photo, tomando um simples café a partir das 19 horas (Figuras 31 e 32). 

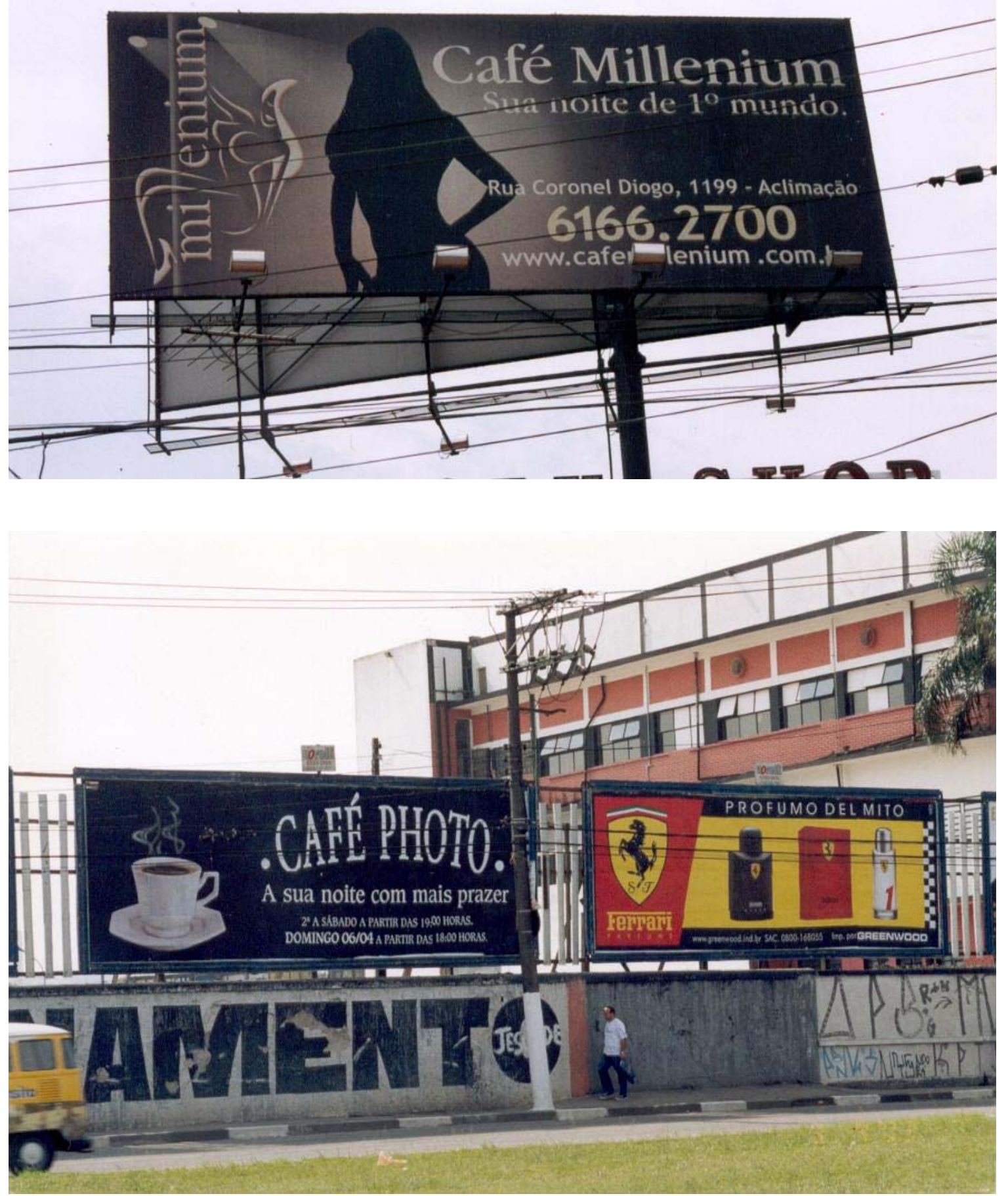

Figuras 31-32 - O prazer de "ter uma noite de $1^{\circ}$. Mundo", na Café Millenium, ou uma "noite com mais prazer", tomando um simples café na Café Photo, eram as mensagens das casas noturnas distribuídas por outdoors das principais ruas e avenidas da capital. 
Uma associação direta do Bahama's Club com a Fórmula 1 pôde ser vista ao lado da ponte Cidade Jardim: "Isso é que é Grande Prêmio", sendo o piloto a coluna em que a dançarina realiza suas performances (Figura 33). A boate Romanza foi um pouco mais discreta ao se associar ao evento pois colocou apenas duas bandeirinhas quadriculadas em seu outdoor. Foi, no entanto, estratégica, por escolher um outdoor na avenida Interlagos, bem próximo ao autódromo.

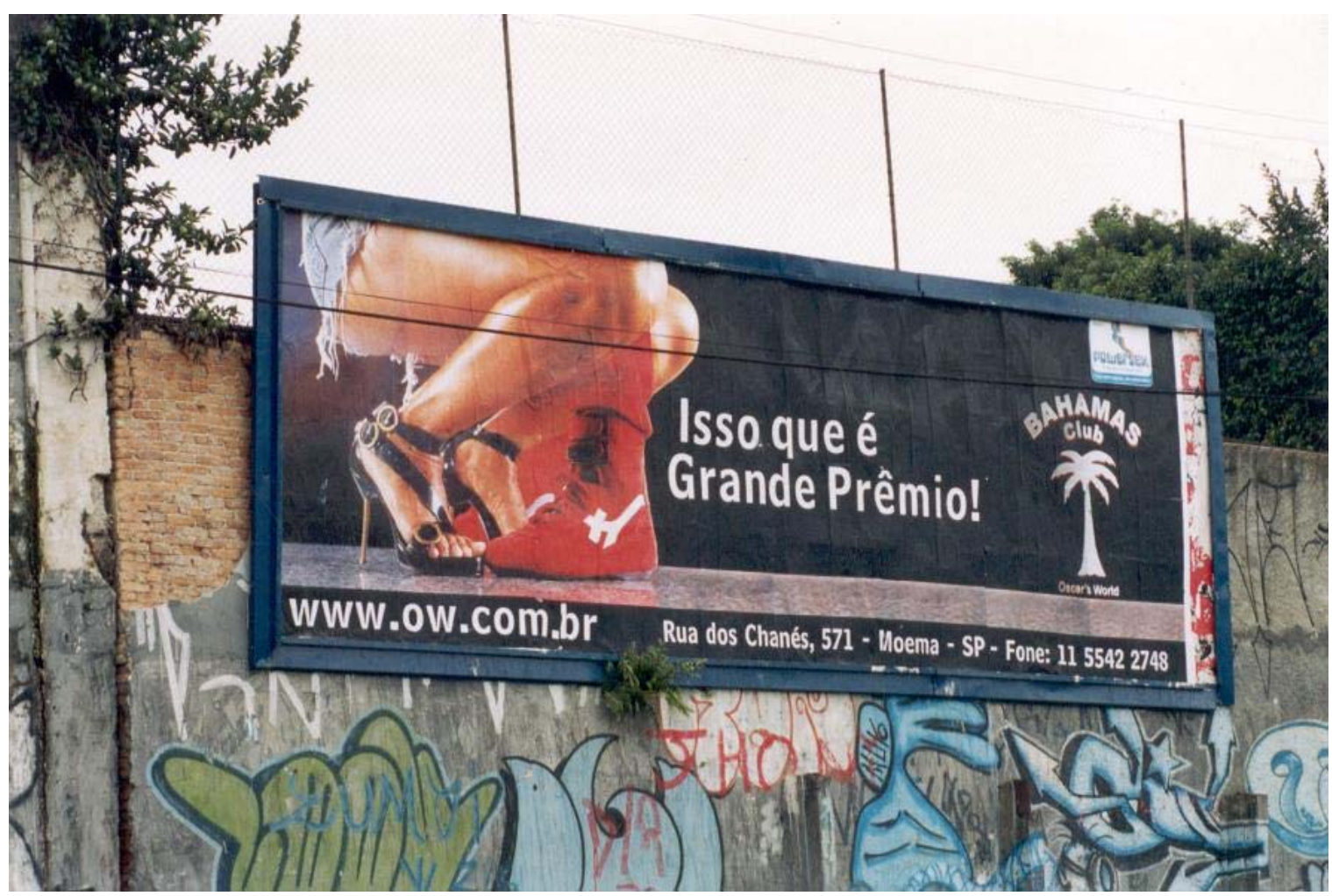

Figuras 33 - Mensagem associada diretamente à Fórmula 1 na propaganda da boate Bahamas, próximo à ponte Cidade Jardim.

Um depoimento do proprietário de uma boate registrou a informalidade da negociação: "Tenho um acordo verbal há seis anos com duas dessas equipes, que já chegam no Brasil com um pacote fechado: hotel, carro e uma noite no Bahamas". Freqüentaram a casa noturna, apenas na quinta-feira que antecede a corrida, 473 homens e 197 mulheres, quando a média de, respectivamente, 250 e 130. No Café Photo, o idioma predominante era o inglês e, para isso, as garotas de programa estavam preparadas. "Algumas gabam-se de serem 'poliglotas', pelo menos no glossário necessário para 'fechar o negócio'” (Ohata; Ribeiro, 2003). 
A presença e a predominância de visitantes do sexo masculino nessas ocasiões estimulam o turismo sexual. Em 2004, três grandes eventos aconteciam num mesmo período em São Paulo: em outubro, eram realizados a Fórmula 1, o Salão do Automóvel e o São Paulo Boat Show. Esses eventos acabaram instigando ainda mais os negócios do entretenimento da noite. Sampaio (2004) constatou junto aos empresários do setor uma elevação do número de clientes nas boates, que também tiveram uma inflação do preço das garotas de programa. O jornalista simplificou o fato apresentando a seguinte equação: "Grande Prêmio Brasil de Fórmula 1 + Salão do Automóvel + São Paulo Boat Show = invasão de homens avulsos na cidade". Esses três acontecimentos importantes atraíram para a cidade cerca de 700 mil pessoas, um público caracterizado por ser, em sua maior parte, constituído por homens desacompanhados, sem crianças, que passam 15 dias na cidade e que têm muito tempo livre disponível. O jornalista comenta que, apesar do aumentado em relação à participação de mulheres tanto no Salão do Automóvel como no São Paulo Boat Show, predominavam os homens em $75 \%$ do público. Já na Fórmula 1, um levantamento informal dos organizadores constatou que os homens correspondiam a $90 \%$ dos espectadores, sendo que nas arquibancadas, a proporção era de oito homens para cada mulher. O excedente masculino fez subir os preços, inclusive das garotas de programa, que trabalham com esse segmento, e até dos taxistas, que ganhavam à parte uma comissão por cada cliente conduzido às casas noturnas, algo mais compensador do que levar um cliente ao aeroporto de Guarulhos (Sampaio, 2004).

A publicidade feita pelas boates não se restringem ao momento das competições, pois outdoors eram mantidos durante o ano inteiro. Sampaio (2004) registra a variada forma de propaganda: 32 outdoors estavam espalhados pela capital, foram confeccionados 120 mil folhetos, não apenas em português mas também em outros idiomas, como o inglês e o japonês, assim como foi contratado um trio elétrico para circular com garotas durante os três dias da Fórmula 1, nas imediações de Interlagos. Esse chamado "período fértil" (Sampaio, 2004) levou os empresários a estender o horário de funcionamento das boates, que ficaram abertas durante todo o domingo.

Agregado aos investimentos em marketing, um esquema planejado informalmente com a oferta de comissão aos taxistas, garantiu, em 2003, um 
incremento do total mensal em mil freqüentadores em razão da Fórmula 1. Como mostra Sampaio (2004), nessa ocasião e em noites de pico, foram recepcionados 600 homens quando em dias normais se recebiam 180.

No caso da Fórmula 1, verificou-se que, além dos proprietários e gerentes das casas noturnas, os taxistas representam elo importante e, talvez, o mais eficaz para estabelecer conexão entre garotas e clientes. Se por um lado ganham financeiramente por uma simples indicação, normalmente são considerados como profissionais de certa confiança, conhecedores das peculiaridades da sua cidade. Desse modo, esse deveria ser o alvo de uma campanha dos organismos de turismo na tentativa de reverter esse processo, que estimula um mercado informal de um turismo indesejável e intensificar a divulgação de outras formas de entretenimento noturno em São Paulo, como a gastronomia. A questão principal é traçar o perfil desses clientes, procurando conhecer atividades preferidas.

Todas as considerações feitas referem-se ao período que antecede a legislação que proíbe faixas, banners e outdoors e criou regras específicas para estabelecimentos comerciais. Certamente neste ano, todas as pessoas físicas e jurídicas envolvidas com a Fórmula 1 deverão acatar as normas vigentes na cidade de São Paulo. 


\subsection{Acesso e segurança}

Determinados aspectos do acesso ao autódromo José Carlos Pace e, também, da segurança do público registram efeitos nas ocasiões em que se realiza a Fórmula 1.

Mais do que acontece em relação aos outros eventos realizados nesse local a cidade de São Paulo precisa adaptar-se para receber o grande contingente de pessoas que acorrem à capital motivadas pelo evento. Conforme já mencionado, anualmente, cerca de 70 mil pessoas se concentram no autódromo, apenas no domingo - principal dia da Fórmula 1. Esse número chega a 150 mil espectadores para os três dias do evento. Percebe-se que esse volume, e também o seu deslocamento implicam no planejamento geral da infraestrutura e na realização das chamadas "operações especiais". Essas verdadeiras adaptações estão relacionadas: ao acesso, transporte e sinalização; à segurança; e à coleta seletiva de lixo produzido no autódromo e no seu entorno.

No que se refere ao acesso, transporte e sinalização, a Prefeitura de São Paulo, a CET - Companhia de Engenharia e Tráfego e a SPTRANS - São Paulo Transporte S/A realizam, anualmente, operações especiais para atender a grande demanda, visando proporcionar facilidades de locomoção a todos os envolvidos nesse evento. Conforme Anzen e Malinverni (1998), esse planejamento, que acontece desde 1990, foi reconhecido mundialmente pela sua organização e qualidade. Em 1993, a convite da FIA, esse projeto foi apresentado durante o Grande Prêmio de Portugal (Figuras 34 e 35). 

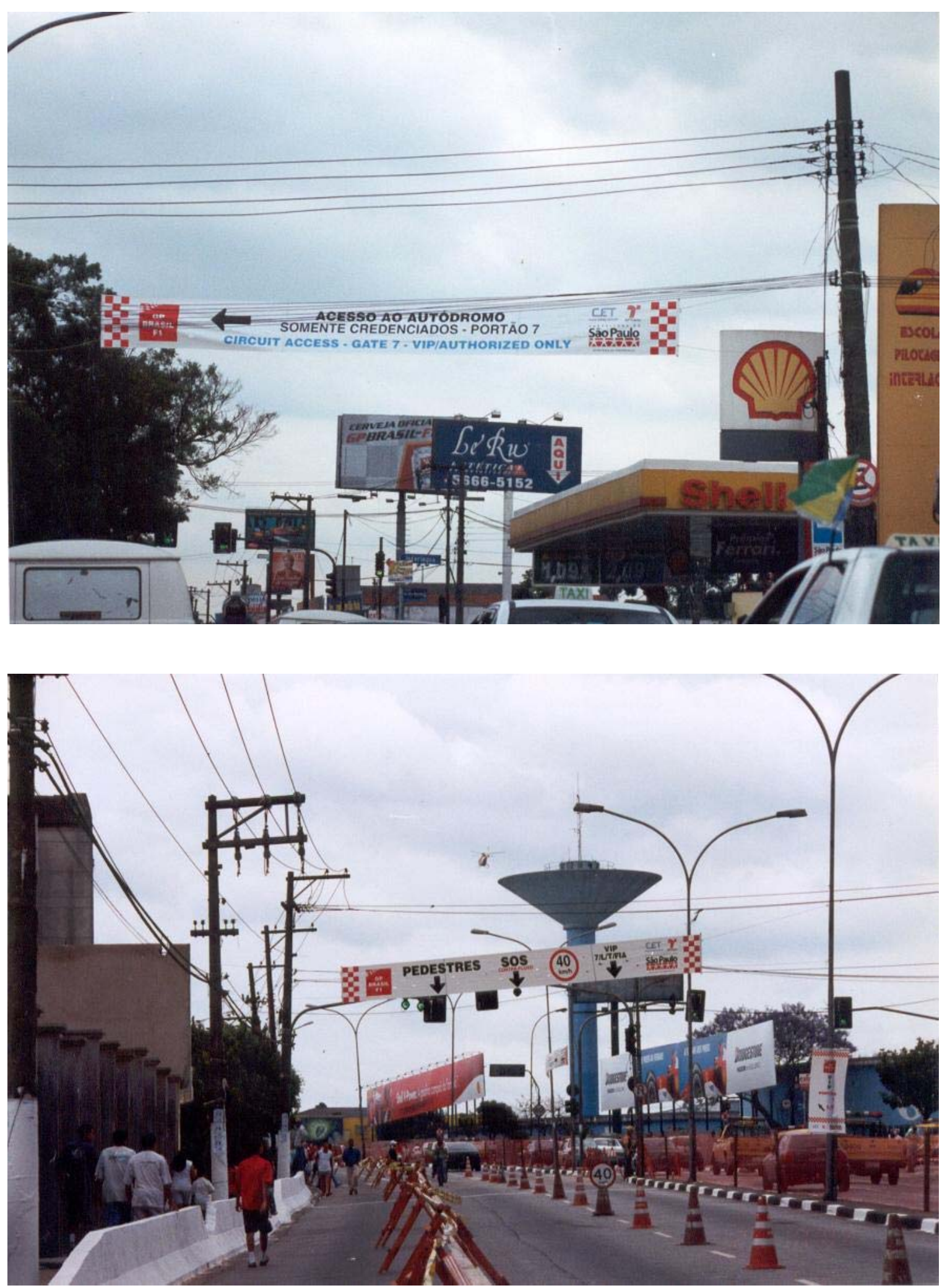

Figuras 34 e 35 - Sinalização da CET revela formas de circulação adequadas aos diversos tipos de público, como credenciados, de setores vip, de atendimento médico e pedestres. 
Como parte das "operações especiais" o anel rodoviário de acesso a São Paulo ganha placas indicativas à entrada de todas as rodovias - Ayrton Senna, Dutra, Fernão Dias, Bandeirantes, Anhanguera, Castelo Branco, Raposo Tavares, Imigrantes e Anchieta. Já nas proximidades do autódromo, automóveis e ônibus fretados podem estacionar em bolsões localizados nas vias principais de acesso existentes nos dois mini-terminais: um na avenida das Nações Unidas e outro na avenida Interlagos. Destes bolsões partem vans ou ônibus circulares que levam as pessoas até o portão do autódromo (Figuras 36 e 37). Ônibus especiais estão disponíveis em duas estações de metrô, a da República e a do Jabaquara, e também num ponto adicional no aeroporto de Congonhas.
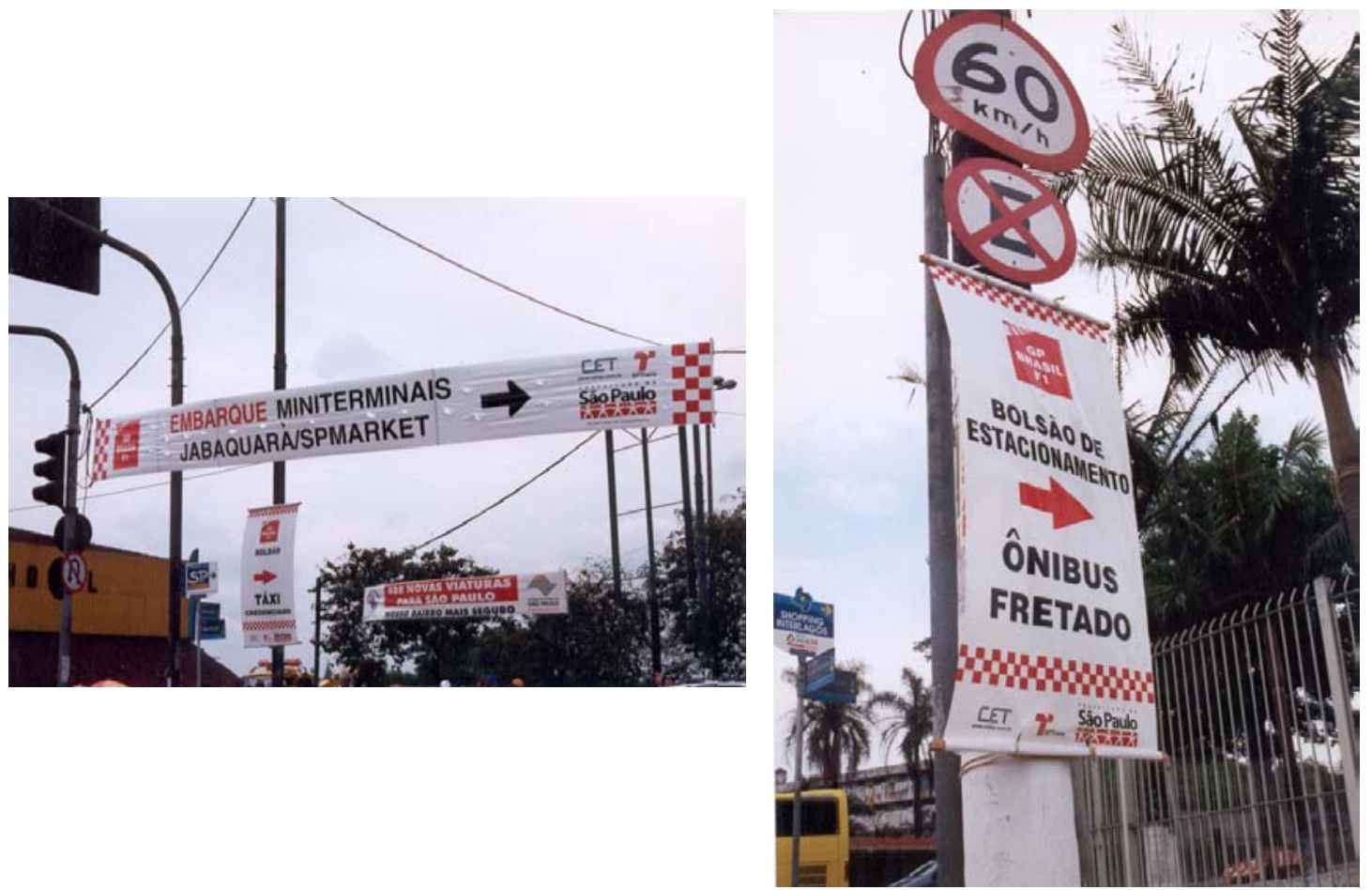

Figuras 36 e 37 - Sinalização da CET define espaços destinados exclusivamente ao estacionamento de automóveis e de ônibus, além aos táxis credenciados.

O congestionamento nas ruas próximas ao autódromo principalmente por ocasião das saídas dos treinos e da corrida é inevitável. No momento da Fórmula 1, a área mais próxima ao autódromo é interditada para veículos a partir da noite de sábado. O acesso é, portanto, restrito, e apenas aos moradores é permitido entrar mediante apresentação de credencial, distribuída 
antecipadamente pela CET. A avenida Interlagos torna-se mão única desde as 5 horas do domingo, passando a ter sentido único nas suas duas vias. Outras ruas são interditadas, como é o caso da avenida Senador Teotônio Vilela (Figuras 38 e 39).
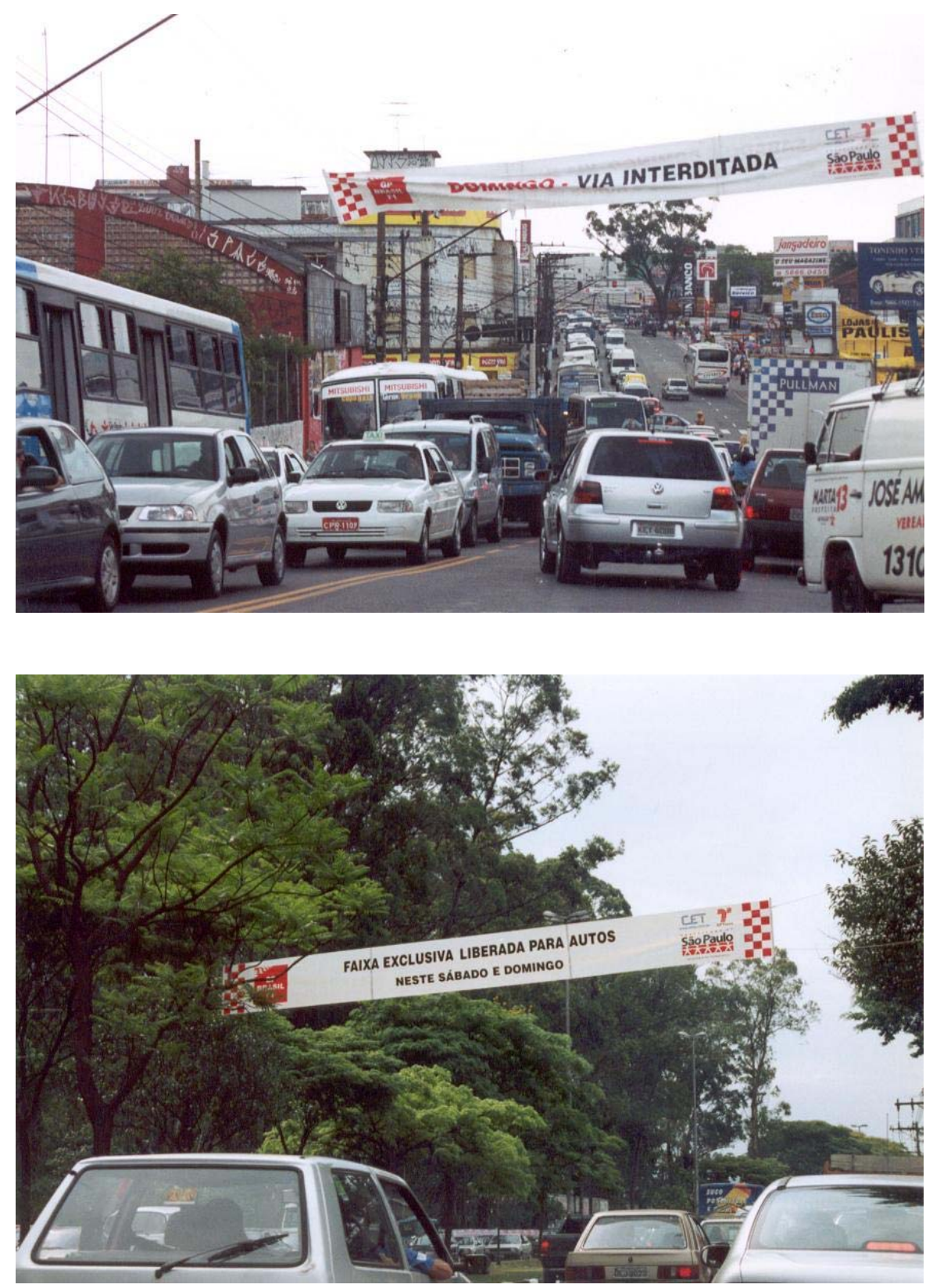

Figuras 38 e 39 - Vias interditadas e faixas exclusivas para ônibus: práticas da CET para favorecer o fluxo de veículos nas ruas próximas ao autódromo de Interlagos.

Conforme exigências da FIA, para a realização da Fórmula 1, as pessoas portadoras de necessidades especiais devem ter exclusividade para o deslocamento até o autódromo. Para tanto, a Prefeitura Municipal oferece o "Serviço Atende" por meio da SPTRANS. Atendendo, também, exigências da 
FIA, há rampas de acesso, além de uma tribuna exclusiva para essas pessoas dentro do autódromo.

O helicóptero, outro meio de transporte utilizado para chegar ao autódromo, tem uso intensificado durante a Fórmula 1, embora restrito a poucos privilegiados como pilotos e dirigentes de equipes. Segundo estimativas de 1998, cerca de 2500 pessoas utilizaram esse tipo de serviço durante os três dias do evento, o que envolveu pelo menos 50 helicópteros, com vôos de 7 a 16 minutos. O centro de operações aéreas é o kartódromo, que nesse momento é controlado pela FAB - Força Aérea Brasileira e INFRAERO - Empresa Brasileira de Infra-Estrutura Aeroportuária. (Anzen; Malinverni, 1998). Existem dois helipontos, sendo que a condição mínima exigida pela FIA é de apenas um.

A Fórmula 1 provoca efeitos, também, nos aeroportos internacionais de Congonhas (São Paulo), Cumbica (Guarulhos) e, ainda, no de Viracopos (Campinas). Os dois primeiros recebem, principalmente, passageiros. Haddad et al (2004) citam levantamento realizado pela Anhembi Turismo e Eventos da Cidade de São Paulo, atual SPTuris, cuja estimativa revela que dos nãoresidentes na capital, 13\% são estrangeiros, o que representa cerca de 7.700 pessoas.

Com relação ao transporte de cargas, considerando veículos e equipamentos das equipes e assessores, chegam separada e antecipadamente, via Aeroporto Internacional de Viracopos situado a $90 \mathrm{Km}$ de São Paulo, em vôos fretados ${ }^{15}$. O material foi descarregado durante toda uma tarde, numa operação supervisionada pelo representante da FOCA - Associação dos Construtores da Fórmula 1. A carga passou pela alfândega do Aeroporto Internacional de Cumbica, em Guarulhos, no início da noite e chegou ao autódromo de Interlagos às 22 horas. O restante dos carros que disputaram o Grande Prêmio do Brasil chegou, posteriormente, em três vôos fretados da VARIG.

Alguns efeitos podem ser observados, ainda, na viagem de regresso de todos os carros e equipamentos das equipes. Após o encerramento da Fórmula 1, logo depois do final da prova, inicia-se a corrida dos agentes de carga da VARIG para embarcar as mais de 300 toneladas de equipamentos das

\footnotetext{
${ }^{15}$ Em 1992, a carga foi avaliada, para efeito de seguro, em U\$ 50 milhões e o transporte feito num Boeing $747-200$ custou U\$ 270 mil.
} 
escuderias que disputaram o Grande Prêmio do Brasil. Trabalhando em ritmo acelerado, vários funcionários fazem revezamento constante para deixar o autódromo livre. Embalagens, empilhadeiras e carretas despacham os containers com o material no Aeroporto Internacional de Cumbica.

Aspectos da segurança do público também têm sido objeto de planejamento por parte dos setores pertinentes. Efeitos da grande demanda da Fórmula 1, numa metrópole como São Paulo, implicam na adoção de medidas especiais de segurança, capazes de coibir excessos e garantir a tranqüilidade dos visitantes e da população em geral. Embora possa existir segurança privativa, o conjunto das operações compete ao setor público, neste caso específico, à Prefeitura Municipal de São Paulo que conta com o apoio de outros organismos também públicos.

Assim como acontece com o acesso, a grande demanda provoca efeitos similares nas medidas de segurança. Como exemplo, foram analisados, com maiores detalhes, os anos de 2002 e 2003 por terem concentrado preocupações mais intensas com essa questão.

Em 2002, o serviço de segurança pública foi mais rigoroso em relação aos anos anteriores pois, além de problemas antigos e corriqueiros, foram freqüentes nos primeiros meses desse ano numerosos episódios de seqüestros e de violência ( $O$ Estado de São Paulo, 2002). Esses fatos, amplamente noticiados pelos jornais e pela TV, fomentaram preocupações com a segurança em geral, tornando, ainda maior, a necessidade de prevenção, considerando-se que a Fórmula 1 é um evento internacional que atrai um público bastante numeroso e diversificado quanto à origem.

Ainda em 2002, foi criado um sistema de vigilância, com câmeras 24 horas, por iniciativa dos próprios organizadores do evento (O Estado de São Paulo, 2002). O poder público designou mais de 3.000 pessoas para garantir a segurança do autódromo e de seu entorno. Trabalhavam, conjuntamente, policiais militares e agentes contratados pela organização do evento (O Estado de São Paulo, 2002). Esse contingente foi distribuído proporcionalmente à quantidade de público que transitou pelas ruas, passou pelas portarias e catracas e ocupou as arquibancadas. 
As áreas que concentram mais espectadores, como as portarias e as arquibancadas A e G, contaram com grupos de policiais especificamente designados a esses setores (Figura 40). Outro grupo de policiais ofereceu apoio aos seguranças contratados pelos promotores do evento que asseguram a tranqüilidade nas demais arquibancadas e áreas vip (Revista Grid, 2002).

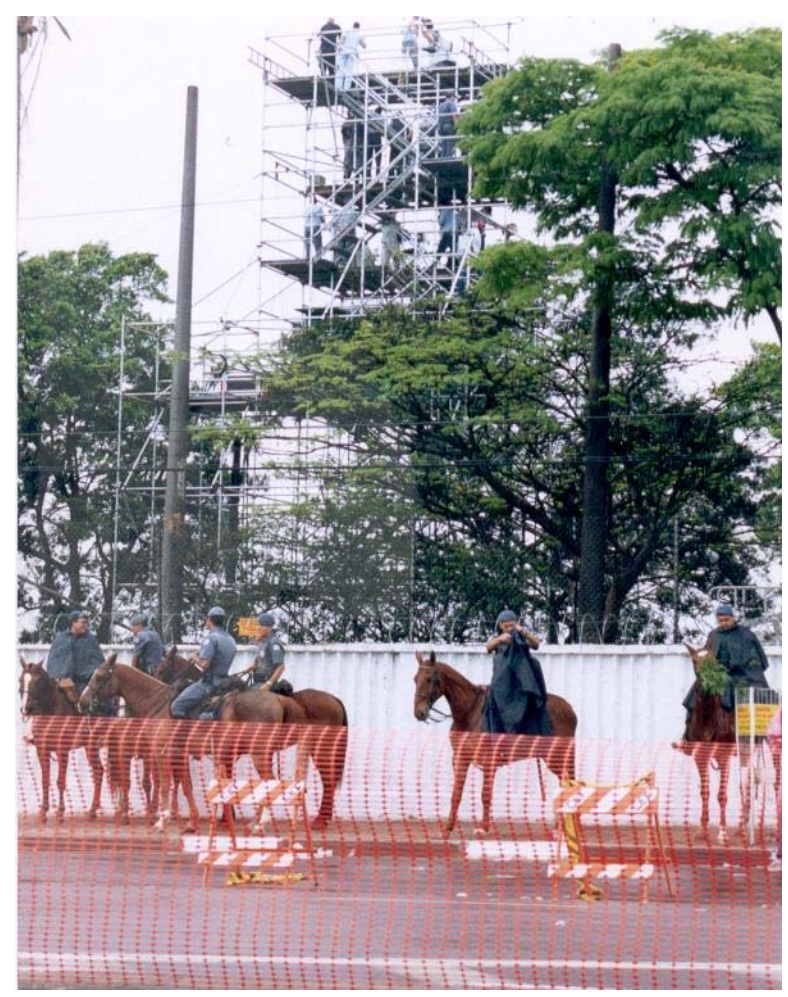

Figura 40 - Espaço destinado a grupos de policiais designados para a segurança do autódromo.

A área externa ao circuito contou com dois outros grupos. Um deles ficou como responsável pelo Controle das Portarias e outro pelo Controle de Distúrbios Civis, que só deveria ser chamado em caso de emergência. Três outras ações receberam atenção dos policiais: a vigilância dos bolsões de estacionamento, a vigilância noturna das filas que se formaram antes da abertura dos portões e a ronda na região do autódromo (Revista Grid, 2002). A vigilância noturna procurou evitar invasões, furtos e depredações.

O resultado das medidas de segurança pública adotadas em 2002 foi satisfatório e, segundo o noticiário, foi um GP marcado pela tranqüilidade. Nesse ano, nenhuma ocorrência foi registrada em Interlagos, apenas na área externa houve uma ocorrência de extorsão por parte dos "flanelinhas" que cobravam 
preços exorbitantes pelo estacionamento nas ruas. Esse fato, comum em São Paulo, persiste em todas as edições da Fórmula 1.

Na ação da Polícia Militar destacam-se duas funções básicas: revistar os espectadores que entram no autódromo, a fim de impedir o porte de armas, entorpecentes ou qualquer objeto que represente perigo a outras pessoas; coibir a atuação de flanelinhas, vendedores ambulantes e cambistas. Para estas ações de segurança preventiva, a Polícia Militar conta com o apoio da Força Tática e da Rota.

Durante os três dias do evento, outros pontos da cidade sofrem os efeitos da Fórmula 1, pois o movimento é mais intenso do que o normal, principalmente nos aeroportos de Congonhas e de Cumbica, nos hotéis onde se hospedam turistas, jornalistas e membros das equipes.

Em 2006, por ocasião dos mencionados treinos que antecedem o evento, os motoristas que tentaram evitar o trânsito da avenida Interlagos em direção à Marginal Pinheiros, entraram na rua adjacente ao autódromo. Nesse acesso, apenas de uso local houve, também, congestionamento e os motoristas acabaram sendo surpreendidos por assaltantes (O Estado de São Paulo, 2006) (Figura 41).

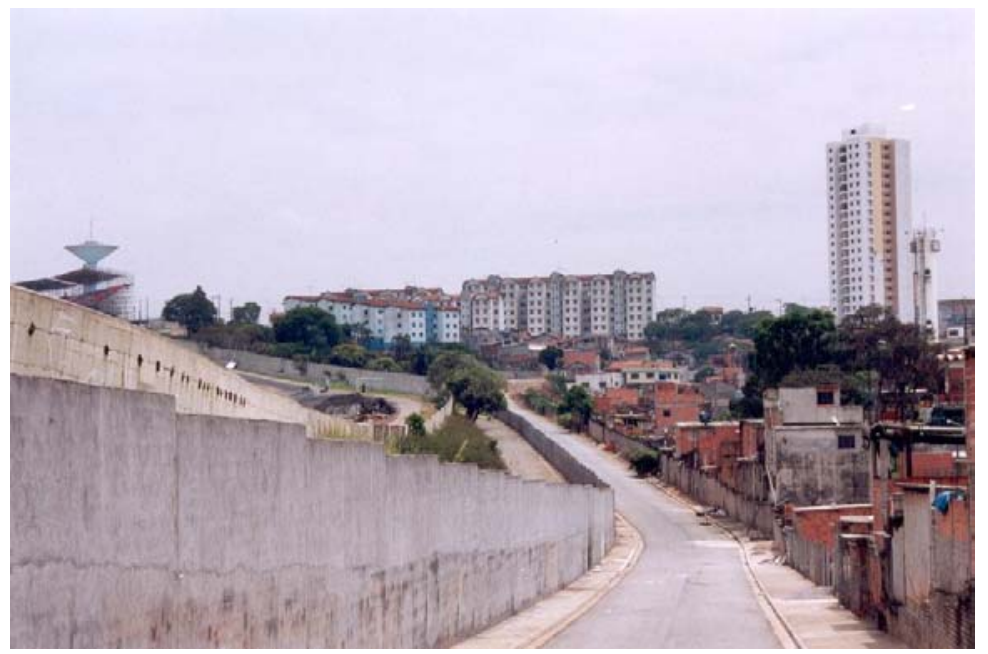

Figura 41 - Rua adjacente ao autódromo de Interlagos que ficou congestionada depois de um dia de treinos da Fórmula 1 de 2006, sendo os motoristas surpreendidos por assaltantes. 
Efeitos mencionados pela população em geral foram detectados nas entrevistas informais junto ao grande público. Alguns reclamaram do congestionamento, da sujeira, do barulho, enquanto outros fizeram referência ao excesso do efetivo policial num único ponto da cidade, deixando desprotegidas outras áreas urbanas.

Deve-se lembrar, ainda, de um dos efeitos mais prosaicos da concentração pessoas - o lixo produzido no autódromo e no seu entorno. Latas e papéis, principalmente, são coletados por pessoas de baixa renda para reciclagem (Figura 42).

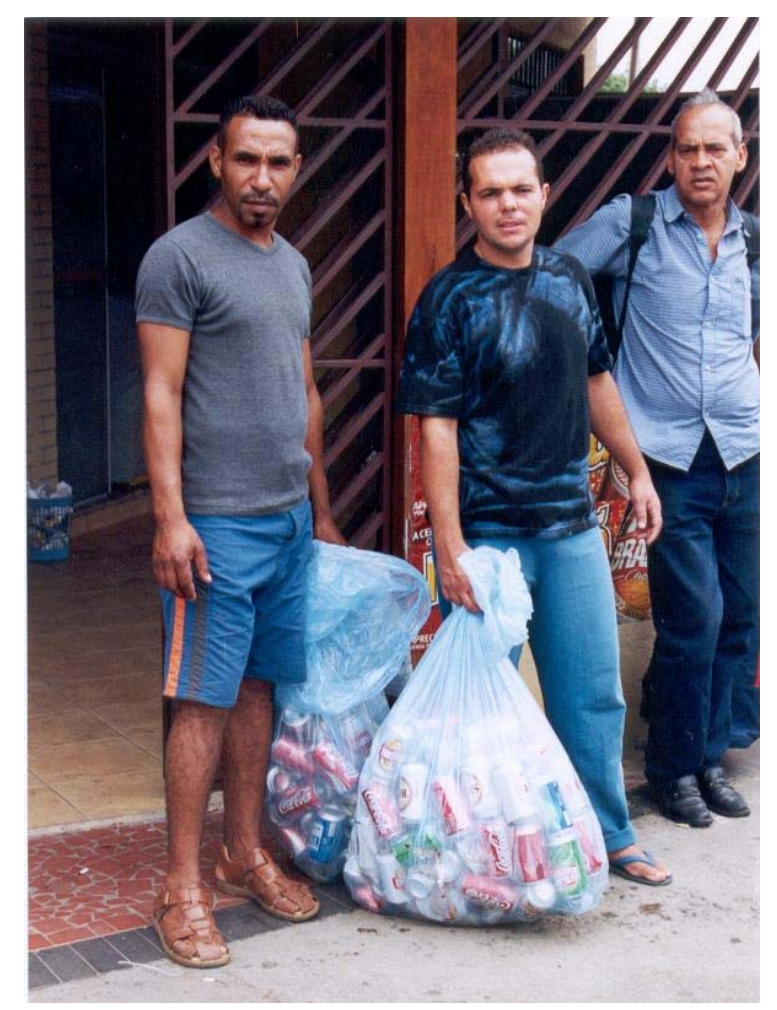

Figura 42 - Latas e papéis, principalmente, são coletados por pessoas de baixa renda para reciclagem.

Efeitos nas vias de acesso, nos transportes e na segurança decorrem, basicamente, do volume da demanda. Cada vez mais percebe-se a importância do planejamento e da organização para o sucesso do evento, o bem-estar e tranqüilidade dos envolvidos. Esta análise mostrou que, na maioria das vezes, os organismos públicos estiveram preocupados com essas questões e conseguiram manter sob controle a maioria dos problemas. 


\subsection{Eventos paralelos}

No caso dos eventos paralelos, os efeitos devem ser vistos no conjunto da programação. Deve-se ser esclarecido que o evento em si mesmo, com exceção da temática automobilística, não apresenta efeitos diretos da Fórmula 1. O que acontece é que o conjunto da programação de eventos paralelos decorre da presença da Fórmula 1 no autódromo José Carlos Pace. Os organizadores desses eventos são estimulados, principalmente, pelo interesse generalizado do público pelo tema e pela visibilidade da Fórmula 1 na mídia.

Esta pesquisa considerou somente efeitos da Fórmula 1 na organização de eventos paralelos ligados ao automobilismo e que se realizam em datas próximas à Fórmula 1, abordando dois grupos de eventos: aqueles realizados no próprio autódromo e outros programados pêra centros de exposições e shoppings da capital. Ambos os grupos, acontecem no mesmo espaço físico e nas datas do Grande Prêmio, sendo, portanto, considerados eventos paralelos à Fórmula 1.

No caso dos eventos do primeiro grupo, o fato de ocorrerem no mesmo espaço físico do Grande Prêmio, leva a considerar que foram criados para aumentar a atratividade da Fórmula 1, oferecendo outras opções para os espectadores. Esses eventos, que incluem competições e exibições foram acrescentados à programação oficial da Fórmula 1 apenas nos últimos cinco anos, ou seja, a partir de 2002. É o caso da realização de uma das etapas da Fórmula 3000 em dias de treinos da Fórmula 1, o que ocorre até hoje, e também da Fórmula Renault Brasil, que aconteceu apenas em 2003. A realização dessas provas paralelamente à Fórmula 1, contribui para divulgar, junto ao público que assiste ao Grande Prêmio, modalidades do automobilismo menos conhecidas, como a Fórmula 3000 e a Fórmula Renault. Deve-se considerar que essas modalidades são patrocinadas por empresas que não têm envolvimento com a Fórmula 1, entretanto têm interesse em divulgar suas marcas no mais importante evento automobilístico internacional.

Ainda no autódromo, merece destaque um evento paralelo relacionado ao antigomobilismo. Os organizadores do Grande Prêmio incluíram, na programação oficial de 2003, um desfile com marcas desaparecidas, o que foi 
divulgado como uma homenagem à memória do automobilismo nacional ${ }^{16}$. Como mostrou a Revista Grid, automóveis antigos de corrida, como a carreteira DKW, o GT Malzoni, o Karmann Ghia Porsche, o Willis MK1, o WW Fittipaldi e o FNM SK, completamente restaurados, entraram no circuito exibindo a numeração com a qual conquistaram notoriedade. O Fitti-Vê, por exemplo, que foi pilotado por Emerson Fittipaldi, em 1968, pôde ser reconhecido pelo número 77 aplicado nas laterais. Verdadeiras relíquias que recordaram a fase romântica do automobilismo nacional quando carros e suas fábricas predominavam nos jornais esportivos da época e foram responsáveis pela formação da primeira geração de pilotos brasileiros a fazer sucesso no exterior (Revista Grid, 2003).

Percebe-se que os eventos realizados para os espectadores da Fórmula 1 no autódromo de Interlagos estão relacionados à essência do automobilismo, baseada na competição e no seu legado.

Além dos eventos realizados no autódromo, outros existem que tornaram-se paralelos à Fórmula 1 quando esta foi transferida de março para outubro, o que ocorreu em 2004. É o caso, por exemplo, do Salão Internacional do Automóvel do Anhembi, mais conhecido como Salão do Automóvel, um dos eventos mais tradicionais da capital que tem como objetivo mostrar as novidades e os avanços do mundo automobilístico, por meio da exposição de carros e equipamentos, o que suscita o interesse dos aficionados pelo automobilismo (Figura 43). Realizado a cada dois anos, no Parque Anhembi, passou a captar a demanda atraída pela Fórmula 1, em virtude da coincidência de datas. Embora não existam referências, este fato foi constatado em entrevistas e informações com os envolvidos no automobilismo.

Menos expressivos do que o Salão do Automóvel, ocorreram, apenas em 2004, três eventos: a História do Automobilismo, a Feira do Automóvel e a Senna Experience. Programados para coincidir com a Fórmula 1, esses eventos tinham em comum a abordagem de fatos e personalidade máxima do automobilismo brasileiro.

Realizada durante 10 dias de outubro de 2004, no shopping D\&D, a "História do Automobilismo", dando destaque para a evolução do design dos carros de corrida, homenageava Ayrton Senna. Nesse caso, os organizadores

\footnotetext{
${ }^{16}$ Esta foi proposta apresentada pelo jornalista Flávio Gomes, colaborador periódico da revista Quatro Rodas, dono de uma coleção de DKWs e diretor da agência de notícias especializada em automobilismo "Warm Up".
} 
divulgaram suas marcas, produtos e serviços num espaço comercial dedicado à arquitetura e decoração chamando a atenção do público, numa época em que a Fórmula 1 estava em evidência. A Feira do Automóvel realizada, em 2004, no Transamérica Expo-Center foi divulgada, sobretudo, em outdoors, um deles localizado na avenida Interlagos, adjacente à ponte Jurubatuba (Figura 44).

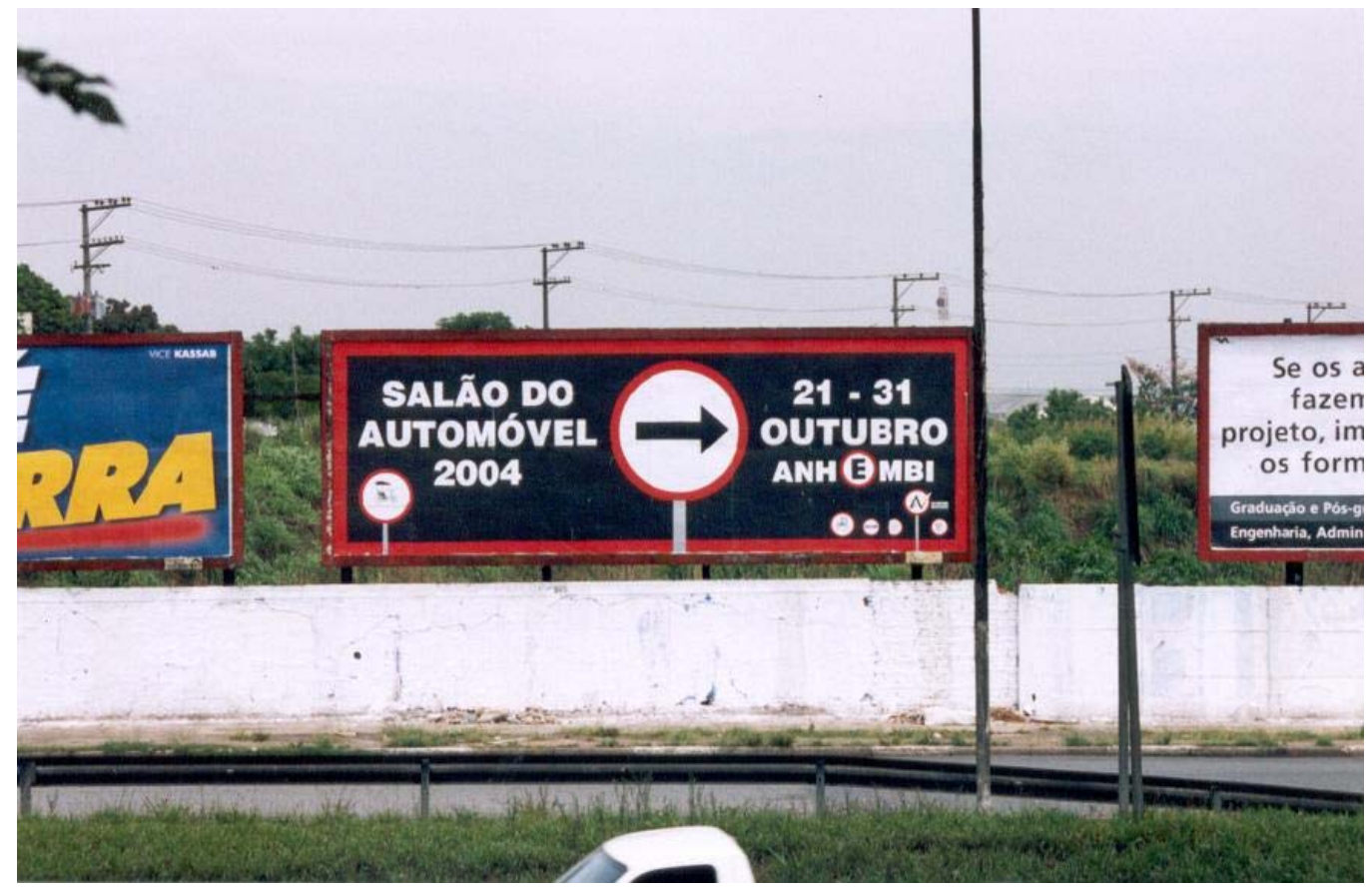

Figura 43 - Divulgação do Salão do Automóvel, no Parque do Anhembi, feita na avenida dos Bandeirantes.

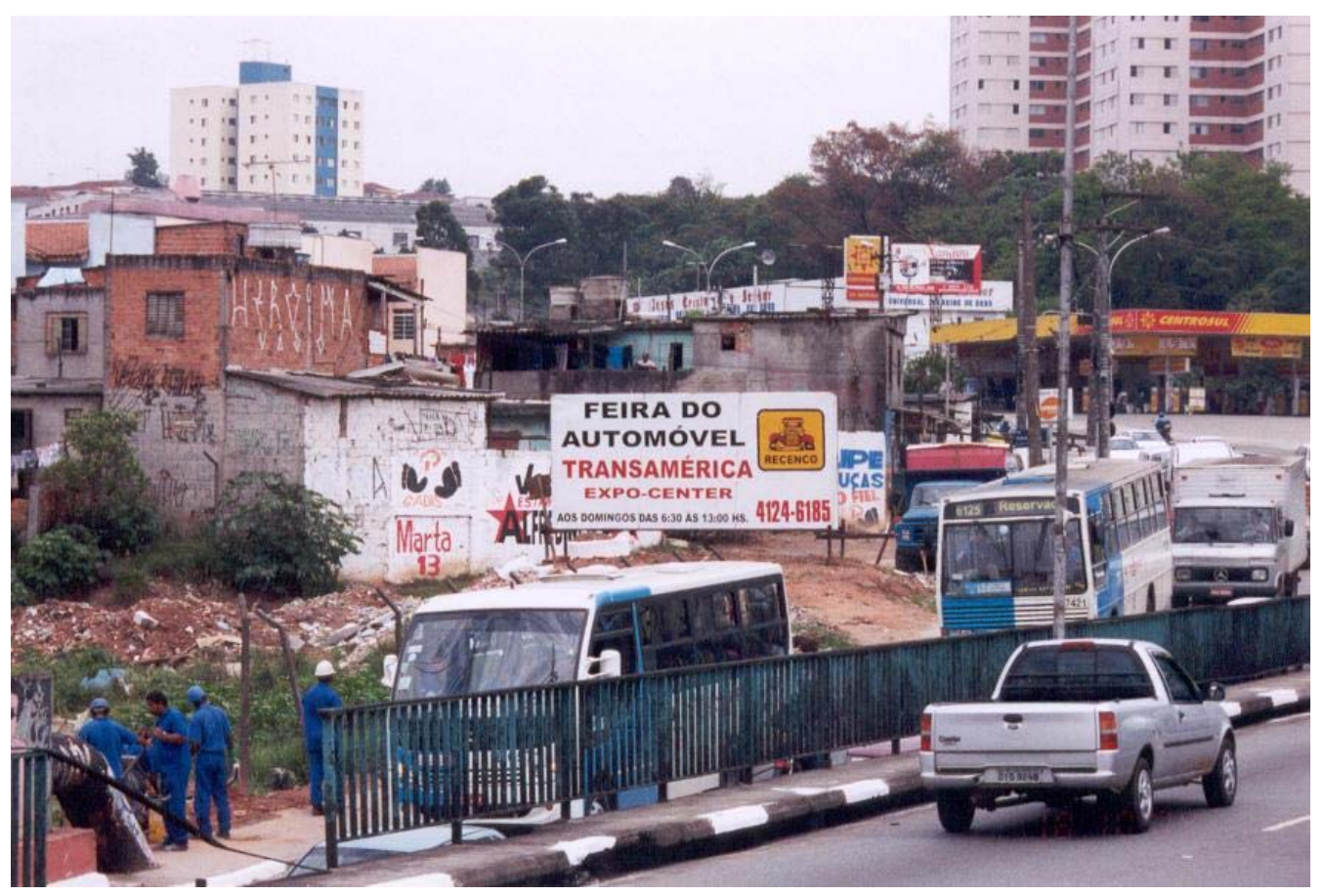

Figura 44 - Divulgação da Feira do Automóvel, no Transamérica Expo-Center, feita junto à ponte Jurubatuba. 
A "Senna Experience" foi realizada em homenagem ao ídolo por ocasião dos 10 anos de sua morte. $O$ Instituto Ayrton Senna, em parceria com a agência Sight Momentum, organizou uma exposição itinerante, que percorreu não apenas o Brasil, mas também o exterior. Durante quatro meses o evento permaneceu no Shopping Eldorado, na zona oeste de São Paulo, um local de fácil acesso e que permite o contato com públicos de diferentes camadas sociais. Depois da capital paulista, a exposição foi para o Rio de Janeiro, Curitiba e uma capital do Nordeste. No exterior, passou pela França, Alemanha, Inglaterra, Itália e Japão.

Essa exposição apresentou como diferencial a interatividade com os visitantes. O outdoor que sobressaía no cenário paulistano mostrava que o evento era "uma grande exposição em tamanho e emoção" (Figura 45). A vida, o legado e os ensinamentos do tricampeão brasileiro foram mostrados por meio de recursos eletrônicos e tecnológicos, como carros semelhantes aos da Fórmula 1 utilizados por Senna que funcionaram como simuladores, à disposição do público. Os espaços disponíveis para visitação apresentaram os valores do tricampeão em formato inédito: o público pôde descobrir detalhes da vida do piloto, movimentar-se dentro de espaços interativos e, em vários momentos, se sentir como se estivesse pilotando carros da Fórmula 1 nos circuitos por onde o piloto passou. Durante o Grande Prêmio do Brasil desse ano, a exposição recebeu a famosa Lótus Renault JPS utilizada por Senna na temporada de 1986 (Galbraith, 2004b).

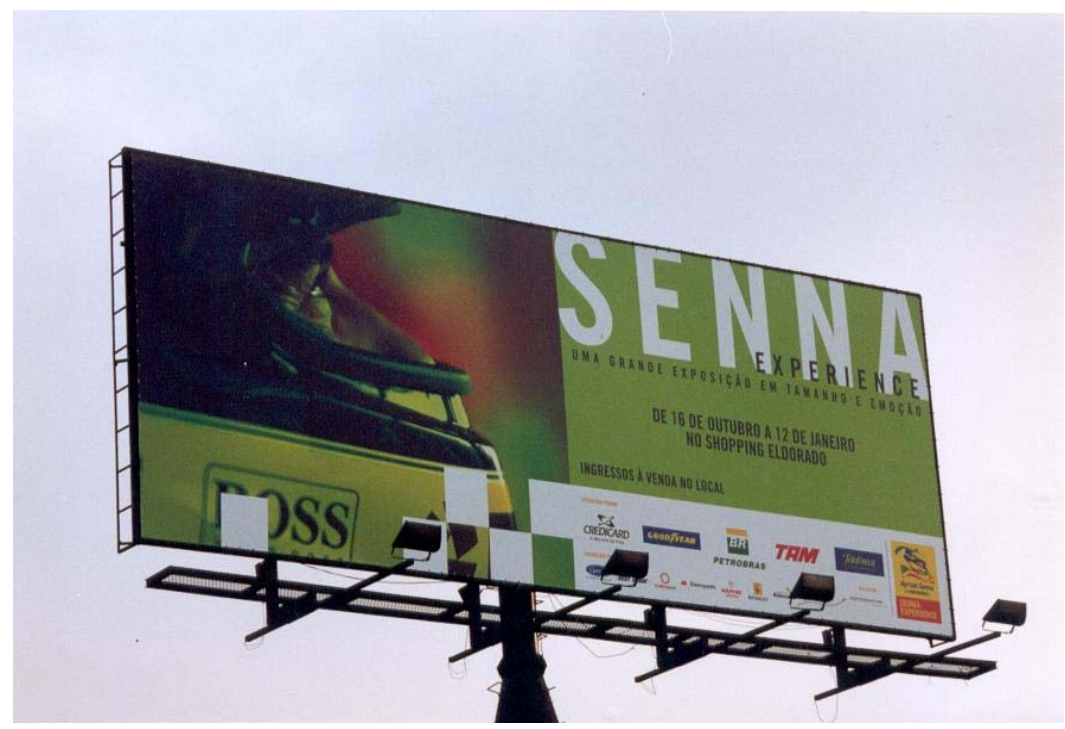

Figura 45 - Divulgação da exposição "Senna Experience" na avenida dos Bandeirantes. 
Aproveitando a coincidência dos eventos em 2004, a Prefeitura procurou promover a cidade de São Paulo que, então, comemorava os 450 anos de sua fundação. Os organismos públicos envolvidos diretamente com o turismo da capital, a Anhembi Turismo e Eventos (atual SPTuris) e a Prefeitura de São Paulo, divulgaram a cidade como a "Capital Mundial do Automobilismo" (Figura 46).

Apesar dos fatos favoráveis, a tônica dessa campanha contou apenas com a exposição de banners em alguns pontos da capital, como a avenida Paulista e as proximidades do autódromo. A iniciativa não foi acompanhada por reportagens, tampouco outras formas de divulgação na mídia. A campanha pelo título poderia ter sido mais intensa e ostensiva e distribuída em pontos adequados, explorando o momento da Fórmula 1 para incentivar o turismo na capital. O slogan acabou se dissipando no meio de tantas outras mensagens publicitárias que, na época, eram tão comuns nas ruas de São Paulo.

A falta de sucesso do slogan "Capital Mundial do Automobilismo" não se deveu, apenas a uma divulgação falha e pontualmente inadequada, mas ao equívoco dos termos empregados que refletem interesses políticos $\mathrm{e}$ momentâneos, sem que qualquer pesquisa tivesse sido desenvolvida.

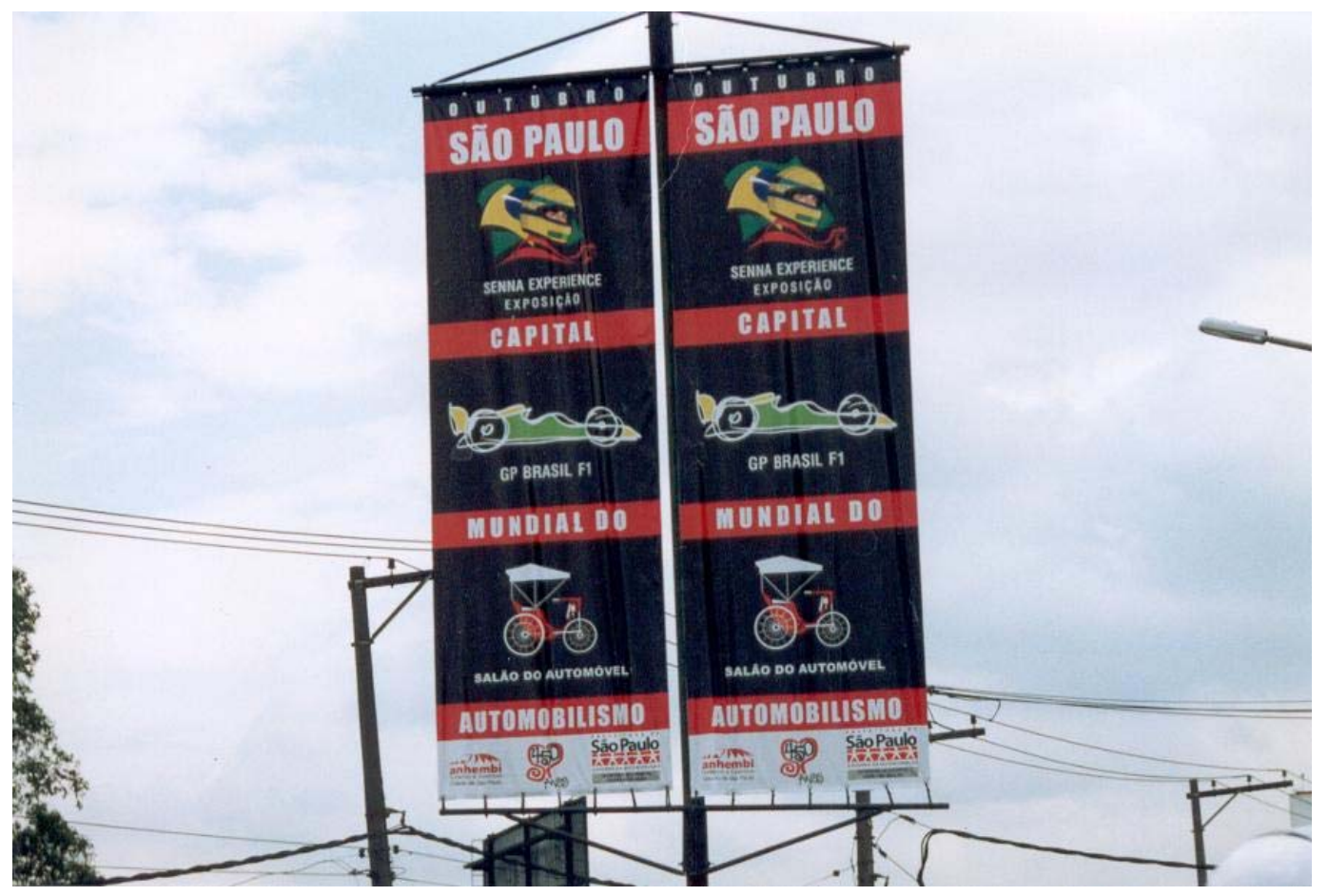

Figura 46 - "Capital Mundial do Automobilismo", uma divulgação promovida pela Prefeitura de São Paulo em 2004. 


\subsection{Aspectos político-econômicos}

O Grande Prêmio do Brasil de Fórmula 1 caracteriza-se por ser um evento internacional realizado conjuntamente pela Prefeitura da capital paulista e pela INTERPRO - International Promotions, que decorre de uma decisão política. Em alguns anos (2003 e 2004), essa realização foi questionada pelo Ministério Público em virtude dos elevados investimentos exigidos, anualmente, para tornar o Autódromo de Interlagos viável para sediar a Fórmula 1 em São Paulo. O mencionado questionamento, de 2003 e 2004, apresentava uma situação de impasse que provocou mudanças na administração dos recursos financeiros, tanto do poder público como das demais organizações envolvidas.

Em novembro de 2003, a $12^{\mathrm{a}}$. Vara da Fazenda Pública emitiu uma liminar suspendendo o contrato entre a Prefeitura de São Paulo e a empresa responsável pela organização e promoção do evento. Essa medida foi tomada devido ao baixo retorno financeiro do evento para a cidade, somado aos balanços negativos das contas municipais. Outros autódromos brasileiros foram considerados como alternativa para transferir a corrida, evitando-se, assim, o pagamento de uma multa diária de $\mathrm{R} \$ 50$ mil por quebra de contrato. $O$ autódromo de Jacarepaguá, na cidade do Rio de Janeiro, estava entre as possibilidades, mas, a construção da Vila Olímpica para os Jogos Panamericanos de 2007, inviabilizava qualquer mudança (Ishikawa, 2003v).

A Secretaria de Negócios Jurídicos da Prefeitura de São Paulo encaminhou, rapidamente, um pedido de suspensão da liminar, mas o Ministério Público afirmava que a cidade tinha gastos excessivos com a realização da corrida, sem o devido retorno financeiro. O poder jurídico municipal, no entanto, alegava que o Ministério baseava seus cálculos somente na arrecadação das bilheterias do autódromo (Ishikawa, 2003v). Deve-se considerar, no entanto, que o Grande Prêmio estimula os negócios como hotéis, bares e restaurantes, além de divulgar a imagem da cidade, algo de difícil ser mensurado.

Enquanto a equipe da Secretaria de Negócios Jurídicos, que assessora a Prefeitura, elaborava novos argumentos para suspender a liminar, a momentânea suspensão do Grande Prêmio desestabilizou todas as empresas envolvidas com a organização da prova. Junto aos promotores, várias empresas 
que, tradicionalmente, investem na corrida solicitavam esclarecimentos. Nesse momento, inclusive a FIA manteve-se neutra, não se pronunciando por tratar-se de um assunto interno. O provável era que a Fórmula 1 fosse declarada em caráter provisório enquanto durasse a pendência judicial (Ishikawa, 2003z).

O Tribunal de Justiça de São Paulo terminou por aceitar o novo recurso da Prefeitura da capital paulista, explicando que não havia urgência do caso, embora, desde 2002, o Tribunal de Contas do Município solicitava esclarecimentos que nunca aconteceram (Ishikawa, 2003x).

No processo de renovação do contrato com a INTERPRO, para o período de 2004 a 2009, a Prefeitura fundamentava o Grande Prêmio como uma realização de ações do Plano Diretor Estratégico, do Plano Plurianual e da Lei de Diretrizes Orçamentárias do Município, e reafirmava as políticas públicas de promoção da cidade, o incremento do turismo receptivo, a inserção de São Paulo no cenário esportivo internacional, além da realização de estudos dos impactos econômicos do evento. Eram adotadas, paralelamente, novas propostas junto aos promotores do evento, inclusive diretamente à FOM - Formule One Management, empresa que gerencia a Fórmula 1. O novo contrato, estabelecido para o período de realização da Fórmula 1 entre 2004 e 2009, foi firmado com alterações que garantiam que a Prefeitura teria menos despesas com a corrida. A promotoria, por sua vez, pontuava três objetivos: a diminuição dos custos da corrida, a busca de parceiros da iniciativa privada para a montagem das arquibancadas e um estudo do retorno financeiro para a cidade (SPTuris, 2004).

Num primeiro momento, essa nova situação também representou um problema adicional para a INTERPRO que reconhecia não saber de que forma captaria os recursos necessários para realizar as corridas a partir de 2005. Dentre os argumentos estavam a incerteza da situação econômica do país a curto prazo, a necessidade de detalhes financeiros, a perspectiva de prejuízos com a corrida de 2004 e a mesma postura empresarial de contenção de despesas por parte da FIA (Folha de São Paulo, 2004).

A alteração da data do Grande Prêmio do Brasil de Fórmula 1, por exemplo, passando do início para o fim da temporada, constituía uma medida para reduzir custos com transportes pois o Mundial poderia ser organizado de acordo com dois blocos: as corridas na Ásia e na Oceania, durante o início do 
campeonato, e os demais - Brasil, Canadá e Estados Unidos - no final da temporada (Seixas, 2003e).

Já em 2002, a FIA promoveu um encontro, em Paris, com a participação de dirigentes de equipes, fornecedores de motores e pneus e dos principais patrocinadores para discutir a diminuição dos custos das categorias. Pretendiase economizar U\$ 250 milhões por ano. Dentre as várias medidas a serem adotadas nos anos subseqüentes estava o aumento da vida útil dos motores, além de outros componentes, de uma para duas corridas, em 2005, e para 6 provas, em 2006 (Ishikawa, 2003g).

Os organizadores do evento, conforme dados fornecidos pela INTERPRO apud Haddad et al (2004), assumem despesas de R\$13.78 milhões, sendo, por ordem de importância, com produtos e serviços de impostos, alimentação, segurança, montagem de arquibancadas, órgão esportivo e direção da prova, seguros, engenharia, transporte, logística e equipamentos, organizações esportivas, vendas de ingressos, impressos, cartazes e gráfica, cenografia, montagem de estandes, locação de móveis, logística interna, assessoria de imprensa, taxas da Polícia Militar, serviços diversos, uniformes, assessoria legal e comunicação, através da ANATEL.

Os investimentos da Prefeitura, que totalizam R 24.782 milhões, são utilizados para cobrir despesas com arquibancadas, reforma e adequação da pista do autódromo, suporte técnico, adequação da área técnica, como obras e serviços de complementação, telemetria, limpeza, reforma e adequação do autódromo, segurança, aluguel de equipamentos de grande porte, serviços técnicos de sinalização e serviços técnicos profissionais junto à EMURB (Prefeitura Municipal de São Paulo apud Haddad et al, 2004).

Os investimentos no autódromo realizados, anualmente, alavancam o desenvolvimento de todas as demais atividades existentes no autódromo, tanto em relação aos programas destinados à população do bairro como ao automobilismo. A CBA verificou um aumento de 2.300 para 4.715 pilotos filiados na Federação paulistana, entre 2002 e 2003, o que, somado aos demais organismos nacionais chegava a computar 8 mil em todo o país. Cada equipe de automobilismo possui, em média, cinco pessoas como assistentes e, portanto, direta ou indiretamente, estavam envolvidas em eventos esportivos cerca de 65 
mil pessoas. Caso o Grande Prêmio não fosse realizado, a conservação do autódromo e o desenvolvimento do automobilismo em Interlagos estariam prejudicados devido à falta de manutenção da infra-estrutura (Miras, 2004).

Como parte dos compromissos assumidos entre a Prefeitura e o poder judiciário municipal, estava a diminuição dos gastos, especialmente com a acomodação dos espectadores e com as obras de recapeamento da pista. A princípio, o novo contrato diminuía de 80 para 70 mil lugares a capacidade do espaço destinado ao público, mas, mesmo assim, a montagem das arquibancadas ainda continuava onerosa. Apenas na montagem das arquibancadas foram gastos, em 2002, cerca de $R \$ 8$ milhões e, em 2003, $R \$ 9$ milhões. O recapeamento do asfalto da pista e a construção de novas áreas de escape também exigiram verbas elevadas, em torno de $R \$ 5$ milhões. A proposta era construir, então, seis módulos de arquibancadas permanentes, de até mil lugares cada uma, que tinham um custo estimado de $R \$ 2$ milhões.

Uma das ações da Prefeitura foi levar o assunto ao Governo Federal na tentativa de conseguir mais um participante do consórcio. O governo era, possivelmente, o terceiro parceiro, depois da TV Globo, e se comprometeu por meio das empresas estatais. A Petrobrás oficializou, em 2004, o interesse, construindo um módulo de arquibancada na frente dos boxes do circuito de Interlagos.

Responsável pela transmissão da corrida, a Rede Globo arca com boa parte dos custos de produção televisiva da Fórmula 1 e também estava, em 2004, interessada em parceria com o setor público já que encontrava dificuldades para canalizar mais recursos para o Grande Prêmio. Como explicou a Globo, a participação estatal em eventos esportivos acontece em outras partes do mundo (Folha de São Paulo, 2004). Em contrapartida estava o retorno no incremento do turismo, dos negócios e da visibilidade internacional.

Segundo o secretário municipal de Esporte, por exemplo, o ganho de "trazer a Fórmula 1 para São Paulo tem vários objetivos, como os de promover a cidade internacionalmente, gerar empregos, movimentar a economia local e oferecer uma outra opção de lazer para os torcedores que acompanham a categoria". Além disso, "o ganho do Grande Prêmio do Brasil extrapola a cidade 
de São Paulo pois a realização da Fórmula 1 constitui uma projeção da imagem do país" (Folha de São Paulo, 2004).

Nesse mesmo sentido, o superintendente do SPCVB - São Paulo Convention and Visitors Bureau declarou que "dos eventos esportivos que vêm ao Brasil, a Fórmula 1 é o de maior visibilidade e também traz os maiores benefícios econômicos para São Paulo, Nenhum jogo de seleção causa tanto impacto em hotéis, restaurantes e lojas". Em uma avaliação desenvolvida pela instituição, em 2001, a Fórmula 1 provocou um movimento de U\$ 75 milhões durante os dias do evento. "Isso é o que a economia da cidade deixaria de receber se a Fórmula 1 não viesse para cá” (Jornal da Tarde, 2002).

A ABIH - Associação Brasileira da Indústria Hoteleira tem a expectativa anual de receber turistas provenientes, sobretudo, da Argentina e, também, da Colômbia. "Esperamos uma lotação acima de $70 \%$ no fim-de-semana da Fórmula 1 quando a ocupação, costumeiramente, é de 30\%". O Hotel Transamérica, segundo o SPCVB, que fica próximo ao autódromo e, tradicionalmente, recebe integrantes das equipes, reservam 320 apartamentos do total de 400 acomodações. O Mercure Grand Hotel tinha 90\% das reservas destinadas ao público da Fórmula 1, entre eles convidados de grandes empresas, na maior parte patrocinadores, que são os responsáveis pela utilização dos camarotes. O Sofitel, outro exemplo, tem uma ocupação de $100 \%$ de seus quartos na semana do Grande Prêmio (Jornal da Tarde, 2002).

Os aspectos econômicos mais enfatizados, quer por políticos e pela iniciativa privada, quer por especulações da mídia puderam ser avaliados pela FIPE que utilizou métodos de estudos adequadamente empregados para o caso da Fórmula 1. Esse estudo, conforme registraram Ishikawa (2003x) e Oricchio (2003), foi um dos compromissos da Prefeitura da capital junto à Promotoria de Justiça da Cidadania. O documento intitulado "Avaliação do Impacto Econômico do Grande Prêmio do Brasil de Fórmula 1" apresentava informações que comprovam que a cidade, o estado e o país ganham financeiramente com a realização da Fórmula 1. Como demonstram Haddad et al (2004), "do montante de $\mathrm{R} \$ 80.368$ milhões de despesas associadas à Fórmula 1 e injetados na economia da cidade de São Paulo, consegue gerar, direta e indiretamente, um aumento de renda de $\mathrm{R} \$ 62.617$ milhões no país como um todo, sendo que $75 \%$ 
desse aumento ocorre na própria cidade de São Paulo, 8\% no restante do estado e $17 \%$ no restante do país".

As despesas, segundo Haddad et al (2004) são realizadas por três vetores de demanda da Fórmula 1, sendo eles: os participantes e espectadores que têm despesas de $\mathrm{R} \$ 41.857$ milhões; os organizadores do evento com despesas de $\mathrm{R} \$ 13.728$ milhões; e a Prefeitura com $\mathrm{R} \$ 24.782$ milhões. A partir dos gastos de cada uma das partes envolvidas na preparação e realização do Grande Prêmio, as simulações dos impactos totais, por meio de modelos de insumo-produto, permitiram demonstrar os efeitos econômicos do evento na cadeia da estrutura produtiva para bens e produtos demandados. Do total de 42 setores de atividades, as despesas incidem, sobretudo, no de serviços prestados às famílias, na construção civil e na prestação de serviços às empresas. A Prefeitura, responsável por cerca de $1 / 3$ dos recursos injetados na economia da capital responde pelo restante 2/3 que representam um efeito de gastos induzido pelo investimento público, sendo esse apoio fundamental para a realização do Grande Prêmio (Haddad et al, 2004).

A título de demonstração, "para cada $R \$ 1,00$ de recurso investido no evento, a Prefeitura consegue induzir que $R \$ 3,20$ sejam injetados na economia da cidade". Considera-se que poucos projetos ou programas da Prefeitura possam apresentar um poder multiplicador de renda comparável ao da Fórmula 1 como uma política pública. 


\section{Considerações Finais}

Esta pesquisa que trata de Turismo e Automobilismo, mais especificamente dos efeitos da Fórmula 1 em São Paulo, foi desenvolvida considerando três eixos temáticos nos quais são abordados eventos esportivos, o Autódromo Municipal José Carlos Pace em São Paulo e os efeitos do Grande Prêmio na capital.

O primeiro eixo temático tratou dos esportes, da relação entre Turismo e Eventos Esportivos, com ênfase no Automobilismo. A revisão da literatura permitiu verificar que predominam trabalhos estrangeiros, referências pontuais e autores dispersos pelas várias áreas do conhecimento. No Brasil, o estudo desses temas ainda não está consolidado e as referências mostram uma certa confusão quanto ao entendimento de modalidades de turismo que se relacionam aos esportes. Na maioria das vezes sequer existem referências ao Turismo Esportivo e ao Turismo Automobilístico, evidenciando pouca ou nenhuma preocupação com o assunto.

A análise do esporte através dos tempos partiu do significado dos termos mais empregados e das relações que se estabelecem entre o jogo e o esporte com a cultura para explorar questões relacionadas à competição. Verificou-se que, desde os Gregos até hoje, embora os esportes tenham evoluído acompanhando as mudanças da sociedade, ainda existem idéias arraigadas como a forma de participação e as características inerentes às competições e aos jogos. Conclui-se que o esporte assume projeção, também na contemporaneidade como atividade relacionada à vida social, contrapondo-se à simples noção de lazer e divertimento.

Com referência à estrutura e organização do automobilismo e das competições destacou-se a relação do Turismo com o Automobilismo presente na essência do Touring Club, de alguns clubes de automobilismo e de algumas associações. Nessa perspectiva, foi possível identificar os organismos internacionais e nacionais voltados para o desenvolvimento do esporte que controlam todas as competições com base em normas, regulamentos e estatutos. A organização das federações e clubes filiados representa a legalidade do esporte e uma força de influência política, com a incumbência de 
planejar, ordenar e regular atividades dos participantes, veículos e infra-estrutura necessários ao automobilismo.

$\mathrm{Na}$ esteira dos clubes de automobilismo estão o antigomobilismo e o fora-de-estrada, ambos direcionados para grupos específicos embora o primeiro tenha relação mais direta com a valorização da cultura e, o segundo, com o envolvimento do esporte com o turismo, privilegiando a emoção e a adrenalina. $\mathrm{Na}$ análise dessas iniciativas no território brasileiro concluiu-se que os clubes de automobilismo dessas modalidades desempenham papel fundamental na organização do esporte e de eventos. Verificou-se, ainda, que tanto o antigomobilismo quanto o fora-de-estrada interferem na vida das comunidades.

A caracterização do autódromo e da Fórmula 1 em São Paulo foi necessária para entender as origens, as transformações na infra-estrutura e as corridas automobilísticas de rua ou de circuito fechado cuja maior expressão é a Fórmula 1.

O Autódromo de Interlagos surgiu em decorrência da disponibilidade de espaço entre as represas Billings e Guarapiranga e das idéias de Louis Romero Sanson, que já previra em seu projeto do bairro Balneário um espaço destinado às corridas automobilísticas como estratégia de marketing para alavancar a venda dos terrenos. Convém considerar, entretanto, que o empreendimento foi favorecido pela falta de segurança dos circuitos de rua na capital e pelo modismo das competições automobilísticas que chegaram ao Brasil muito antes da implantação da indústria automobilística. Constatou-se que as transformações na infra-estrutura do autódromo estão relacionadas às exigências da FIA e explicam os deslocamentos da Fórmula 1 entre São Paulo e Rio de Janeiro.

Com capacidade para 70 mil pessoas, o Autódromo de Interlagos chega a receber cerca de 150 mil espectadores no período da Fórmula 1. A distribuição desse público pelo espaço do autódromo nos diferentes setores de acomodação revelou uma estratificação social, conforme o poder aquisitivo que condiciona a oferta de facilidades e serviços. Algumas questões de segurança envolvendo torcedores e os ídolos foram detectadas por ocasião da Fórmula 1. Essa análise mostrou que, embora a Fórmula 1 tenha grande importância para o autódromo existem outras atividades que extrapolam esse evento, entre as quais aqueles relacionados ao automobilismo, escolas de pilotagem, espaço para área de lazer 
da população e para campanhas de conscientização visando alertar os jovens sobre o perigo da alta velocidade.

Anualmente, a pista de Interlagos é aprimorada, bem como os demais espaços e equipamentos destinados ao Grande Prêmio, embora o foco possa variar conforme as exigências da FIA e os avanços da tecnologia. Constatou-se que, em alguns casos, o aprimoramento das condições físicas resulta de adversidades ocorridas em outros circuitos do Campeonato Mundial.

A questão principal desta pesquisa, que é a análise dos efeitos da Fórmula 1 em São Paulo foi estudada em grupos com destaque para os patrocinadores, a oferta direta de produtos e serviços, o lazer e o entretenimento, o acesso e a segurança, eventos paralelos e alguns aspectos políticoeconômicos. Nesse capítulo, foi possível estabelecer algumas conclusões que comprovam as hipóteses levantadas:

$1^{\circ}$.) a visibilidade da Fórmula 1 na mídia intensifica a publicidade no entorno do autódromo, explorando motivações ligadas às necessidades de aceitação, ao ego e à auto-estima;

$2^{\circ}$.) os patrocinadores do evento e das equipes se aproveitam-se dessa visibilidade da Fórmula 1 na mídia para divulgar produtos e serviços;

$3^{\circ}$.) a oferta direta de produtos e serviços inclui desde estabelecimentos sofisticados, que atendem um público internacional exigente, serviços especializados relacionados ao automobilismo e às escolas de pilotagem, até a oferta de produtos geralmente consumidos pelo público de baixa renda;

$4^{\circ}$.) ficou patente o chamado turismo sexual estimulado por imagens e mensagens difundidos em períodos de corridas automobilísticas e dimensionado nos jornais e revistas;

$5^{\circ}$.) a rotina da cidade é alterada com a Fórmula 1 no que se refere ao acesso, transporte e sinalização e são intensificadas as medidas de segurança;

$6^{\circ}$.) o interesse generalizado do público pela Fórmula 1 estimula a realização de eventos paralelos ligados ao automobilismo; 
$7^{\circ}$.) a Fórmula 1, embora dispendiosa, proporciona benefícios econômicos para a cidade de São Paulo.

Esta pesquisa não esgota um tema tão vasto que pouco tem sido estudado. Muitas questões ligadas ao Turismo Esportivo e ao Automobilismo ainda permanecem sem resposta, dentre elas a caracterização dos turistas, o acompanhamento constante dos efeitos gerados pela Fórmula 1 no entorno do autódromo, a elaboração de conceitos mais precisos para identificar tipos de turismo ligados ao esporte e ao automobilismo, estudos de viabilidade econômica de mega-eventos como esse, avaliação das repercussões positivas e negativas, quantificação dos investimentos na infra-estrutura do autódromo e nas atividades além da Fórmula 1, investigação sobre a percepção de moradores, visitantes, comerciantes e demais agentes envolvidos na competição.

Finalmente, espera-se que esta pesquisa possa contribuir para o estudo do turismo e do automobilismo, esclarecendo idéias e conceitos, mostrando modalidades e organismos relacionados a essas atividades e aguçar o interesse dos aficionados pelo automobilismo enquanto tema de pesquisas acadêmicas. 


\section{Bibliografia}

AIDID, Syed M. 1997. Penang (Malaysia) as a Tourism Sport Centre. Journal of Sport Tourism, vol.4, n.1.

ANDERSSON, T.D. e SAMUELSSON, L.A. 2000. Financial Effects of Events on the Public Sector. In: MOSSBERG, L.L. (ed.). Evaluation of Events: Scandinavian Experiences. USA, Australia, Japan: Cognizant. Cap.6, pp.86-103.

ARBIX, 1997. O automóvel já foi de tudo.

ARNOLD, A., FISCHER, A., HATCH, J. e PAIX, B. 1989. The Grand Prix, Road Accidents and the Philosophy of Hallmark Events. In: SYME et al (eds). Cap.15, pp.186-194.

ARTHUR, David e ANDREW, John. 1996. Incorporating Community Involvement in the Management of Sporting Mega-Events: an Australian Case Study. Festival Management \& Event Tourism, vol.4, pp.21-27.

BACAL, Sarah S. 1987. Interdependência Estrutural da Atividade Turística. São Paulo: Escola de Comunicações e Artes (Tese).

BACAL, Sarah S. Lazer: Teoria e Pesquisa. São Paulo: Loyola. 1988.

BACKMAN, Kenneth F. et al. 1995. Event Tourism: an Examination of Motivations and Activities. Festival Management \& Event Tourism, vol.3, pp.15-24.

BALE, John. 1989. Sports Geography. London: ISBN 0-419-14390-4.

BALE, John. 1993. Sport, Space and the City. London; New Yor: Routledge.

BALE, John. 1994. Landscapes of Modern Sport. London; New York; Leicester: Leicester University Press.

BARBADOS GOVERNMENT. 1997. Sports Tourism in the Barbados - the Development of Sports Facilities and Special Events. Journal of Sport Tourism, vol.4, n.1.

BERITELLI, P., BOKSBERGER, P.E. e WEINERT, R. 2004. An Integrated Concept of Financing Hallmark Sport Events. Tourism Review, vol.59, n.2, pp.33-37.

BOHLIM, M. 2000. Travelling to Events. In: MOSSBERG, L.L. (ed.). Evaluation of Events: Scandinavian Experiences. USA, Australia, Japan: Cognizant. Cap.2, pp.13-29.

BRASINCA, 1989. O século do automóvel no Brasil.

BURNS, J.P.A. e MULES, T.J. 1989. An Economic Evaluation of the Adelaide Grand Prix. In: SYME et al (eds.). The Planning and Evaluation of Hallmark Events. USA, Hong Kong, Singapore, Sydney: Avebury. Cap.14, pp.172-185.

BUTLER, R.W. e GRIGG, J.M. 1989. The Hallmark Event that Got Away: the case of the 1991 Pan American Games and London, Ontario. In: SYME et al (eds.) Cap.12, pp.142-155.

CAMPBELL, Mark B. 1989. Fishing Lore: The Construction of the 'Sportsman'. Annals of Tourism Research, vol.16, pp.76-88.

CARMICHAEL, Bárbara e MURPHY, Peter E. 1996. Tourism Impact $f$ a Roating Sports Events: The Case of the British Columbia Games. Festival Management \& Event Tourism, vol.4, pp.127138.

CARRERAS, Carles. 1996. Turismo Urbano: el Efecto de los Megaeventos. In: RODRIGUES, A.A.B. (org.). Turismo e Geografia: Reflexões Teóricas e Enfoques Regionais. São Paulo: Hucitec. pp.224-237.

CHAMBERS, Deborah A. 1983. Symbolic Equipment and the Objects of Leisure Images. Leisure Studies, vol.2, pp.301-315.

CHON, Kye-Sung. 1990. El impacto de los Grandes Acontecimientos deportivos en la Industria Turística de Corea. Estúdios Turísticos, vol.105, pp.3-6.

COLEMAN, Denis E ISO-AHOLA, Seppo. 1993. Leisure and Health: the Role of Social Support and Self-Determination. Journal of Leisure Research, vol.25, n.2, pp.111-128. 
COWIE, lan. 1989. Possible measures to protect private tenants from any Impact Associated with Hallmark Events with Special Reference to the America's Cup Defence in Perth. In: SYME et al (eds.). The Planning and Evaluation of Hallmark Events. USA, Hong Kong, Singapore, Sydney: Avebury. Cap.7, pp.81-91.

CROCKETT, Shane. 1994. Sports Tourism: Bidding for International Events. Journal of Sport Tourism, vol.1, n.4.

CROMPTON, John L. 1993. Understanding a Business Organization's Approach to Entering a Sponsorship Partnership. Festival Management \& Event Tourism, vol.1, pp.98-109.

CROMPTON, John L. 1994. Benefits and Risks Associated with Sponsorship of Major Events. Festival Management \& Event Tourism, vol.2, pp.65-74.

CROMPTON, John L. 1995. Factors that have Stimulated the Growth of Sponsorship of Major Events. Festival Management \& Event Tourism, vol.3, pp.97-101.

CROMPTON, John L. e LEE, Seokho. 2000. The Economic Impact f 30 Sports Tournaments, Festivals, and Spectator Events in Seven U.S. Cities. Journal of Park and Recreation Administration, vol.18, n.2, pp.107-126.

CUNHA, Licínio. 1997. Economia e Política do Turismo. Portugal: McGraw Hill, 350p.

CUNHA, Licínio. 2001. Introdução ao Turismo. Portugal: Verbo, 447p.

DANN, Graham M.S. 1998. 'Não há empreendimento como os empreendimentos de outrora': o Turismo, a Indústria da Nostalgia do Futuro. In: THEOBALD, William F. (org.). Global Tourism. São Paulo: SENAC. Cap.3, pp.53-66.

DATZER, Robert. 1983. Por qué se Viaja? Los motivos de Viajes de los Turistas Alemanes. Estúdios Turísticos, n.80, pp.95-106.

DEVADOS, Rajammal P. 1997. Sports Tourism in Tamil Nadu (India). Journal of Sport Tourism, vol.4, n.1.

DOMINGUES, Edson P. 2000. Evolução Recente de Produção e Importação de Automóveis no Brasil. Economia Aplicada, vol.4, n.1, pp.73-94.

DOVEY, Kimberly. 1989. Old Scabs/New Scars: the Hallmark Event and the Everyday Environment. In: SYME et al (eds.). The Planning and Evaluation of Hallmark Events. USA, Hong Kong, Singapore, Sydney: Avebury. Cap.6, pp.73-80.

ELSTAD, Beate. 1996. Volunteer Perception of Learning and Satisfation in a Mega-Event: the Case of the XVII Olympic Winter Games in Lillehammer. Festival Management \& Event Tourism, vol.4, pp.75-83.

EMURB, 1979. A cidade e o automóvel.

EUCHNER, Charles C. 1999. Tourism and Sports: the Serious Competition for Play. In: FAINSTEIN, Susan e JUDD, Dennis R. (eds.). The Touristic City. USA: Yale, pp.215-232.

EVANS, Rhonda D.; FORSYTH, Craig J. e WOODDELL, 2000. Macro and Micro Views of Erotic Tourism. Deviant Behavior: an Interdisciplinary Journal, vol.21, pp.537-550.

FAULKNER, Bill e RAYBOULD, Michael. 1995. Monitoring Visitor Expenditure Associated with Attendance at Sporting Events: an Experimental Assessment of the Diary and Recall Methods. Festival Management \& Event Tourism, vol.3, pp.73-81.

FÉRNANDES FUSTER, Luis. 1971. Teoria y Técnica del Turismo. Madrid: Editora Nacional. FERRARA, L.D. 2000. Os significados urbanos. São Paulo: EDUSP, 185p.

FLAGESTAD, Arvid e HOPE, Christine A. 2001. Strategic Success in Winter Sports Destinations: a Sustainable Value Creation Perspective. Tourism Management, vol.22, pp.445-461.

FLOGNFELDT, Thor. 1998. A Spectator's View of the Results of the Development of an Olympic Host Town, before and after the Games (opinião). Festival Management \& Event Tourism, vol.5, pp.93-95.

FREDLINE, E. e FAULKNER, B. 1998. Residents Reaction to a Major Tourist Event: the Gold Coast Indy Car Race. Festival Management \& Event Tourism, vol.5, pp.185-205.

FRÚGOLI JR., H. 2000. Centralidade em São Paulo: trajetórias, conflitos e negociações. São Paulo: Cortez; EDUSP, 264p. 
GETZ, Donald. 1991. Festivals, Special Events and Tourism. New York: Van Nostrand Reinhold. $375 p$.

GETZ, Donald. 1991. Special events. In: MEDLIK, Slavoj. Managing Tourism. UK: ButterworthHeinemann. Cap.12, pp.122-130.

GETZ, Donald. 1997. Event Management \& Event Tourism. USA, Australia, Japan: Cognizant Communication Corporation. 387p.

GETZ, Donald. 1998. O Evento Turístico e o Dilema da Autenticidade. In: THEOBALD, William F. (org.). Global Tourism. São Paulo: SENAC. Cap.24, pp.423-440.

GIBSON, Heather. 1998. The Wide World of Sport Tourism. Park \& Recreation, vol.33, n.9, pp.108-114.

GIBSON, Heather. 1999. Sport tourism: the Rules of the Game. Park \& Recreation, vol.34, n.6, pp.36-45.

GLYPTIS, Sue A. 1991. Sport and Tourism. In: COOPER, C.P. Progress in Tourism, Recreation and Hospitality Management. UK: University of Surrey, vol.3, pp.165-183.

GLYPTIS, Sue. 1984. Leisure Life Styles: Gateway of Cul-de-Sac? In: LONG, Jonathan e HECOCK, Richard (eds.) Leisure, Tourism and Social Change (conference). UK, University of Edinburgh. Centre for Leisure Research. pp.189-203.

GLYPTIS, Sue. 1991. Countryside Recreation. UK: Longman/Institute of Leisure and Amenity Management. 180p.

GOLDBLATT, Joe Jeff. 1990. Sporting Events. In: Special Events: the Art and Science of Celebration. USA: Van Nostrand Reinhold. Cap.27, pp.279-288.

GOLDBLATT, Joe Jeff. 1997. Special Events. UK: John Wiley \& Sons. 385p.

GÓMEZ, José J.M. e MORENO, F.C. 1997. El marketing Social al Servicio de la Gestión de la Calidad. Educación Física y Deportes - Apunts, vol.57, pp.77-83.

GOODRICH, Jonathan N. 1993. Socialist Cuba: a Study of Health Tourism. Journal of Travel Research, vol.32, n.1, pp.36-41.

GRATTON, Chris, DOBSON, Nigel e SHIBLI, Simon. 2000. The Economic importance of Major Sports Events: a Case-study of Six Events. Managing Leisure, vol.5, pp.17-28.

GREEN, B. Christine e CHALIP, Laurence. 1998. Sport Tourism as the Celebration of Subculture. Annals of Tourism Research, vol.25, n.2, pp.275-291.

GREGSON, Paul William. 2002. Os Eventos de Antigomobilismo sob a Análise Turística. São Paulo: STS, 129p.

HADDAD, Eduardo A., KADOTA, Décio K. e RABAHY, Wilson A. 2004. Impactos Econômicos do Grande Prêmio Brasil de Fórmula 1. Turismo em Análise, vol.15, n.2, pp.216-228.

HALL, C.M. 1987. The Effects of Hallmark Events on Cities (conferência). Journal of Travel Research, vol.26, n.2, pp.44-45.

HALL, C.M. 1989. Hallmark Events and the Planning Process. In: SYME et al (eds.). The Planning and Evaluation of Hallmark Events. USA, Hong Kong, Singapore, Sydney: Avebury. Cap.2, pp.20-39.

HALL, C.M. 1989. Hallmark Tourist Events: Analysis, Definitions, Methodology and Review. In: SYME et al (eds.). The Planning and Evaluation of Hallmark Events. USA, Hong Kong, Singapore, Sydney: Avebury. Cap.1, pp.03-19.

HALL, C.M. 1989. The Politics of Hallmark Events. In: SYME et al (eds.). The Planning and Evaluation of Hallmark Events. USA, Hong Kong, Singapore, Sydney: Avebury. Cap.19, pp.219241.

HALL, C.M. 1992. Adventure, Sport and Health Tourism. In: WEILER \& HALL. Cap.11, p.141-158.

HALL, C.M. 1992. Hallmark Tourist Events: Impacts, Management and Planning. London: Belhaven, 215p.

HALL, C.M. 1997. Mega-Events and their Legacies. In: MURPHY, Peter E. (ed.) Quality Management in Urban Tourism. England: John Wiley. Cap.7, pp.75-87. 
HALL, C.M. e HODGES, Julie. 1996. The Party's Great, but what about the Hangover?: The Housing and Social Impacts of Mega-Events with Special Reference to the 2000 Sydney Olympics. Festival Management \& Event Tourism, vol.4, pp.13-20.

HALL, C.M. e SELWOOD, John. 1989. America's Cup Lost: Paradise Retained? The Dynamics of a Hallmark Tourist Event. In: SYME et al (eds.). The Planning and Evaluation of Hallmark Events. USA, Hong Kong, Singapore, Sydney: Avebury. Cap.9, pp.103-117.

HANEFORS, M. 2000. The Locals - Local Knowledge, Participation, and Identity. In: MOSSBERG, L.L. (ed.). Evaluation of Events: Scandinavian Experiences. USA, Australia, Japan: Cognizant. Cap.4, pp.47-62.

HARRIS, Rob et al. 2001. Towards an Australian Event Research Agenda: First Steps. Event Management, vol.6, pp.213-221.

HERBIN, J. 1995. Mass Tourism and Problems of Tourism Planning in French Mountains. In: ASHWORTH, G.J. e DIETVORST, A.G.J. (eds.). Tourism and Spacial Transformations: Implications for Policy and Planning. UK: CAB. Cap.6, pp.93-105.

HEWINGS, Geoffrey J.D. et al. 2002. Economic Impact of the LaSalle Banks Chicago Marathon. USA: University of Illinois, Regional Economics Application Laboratory.

HIGHAM, James e HINCH, Tom. 2002. Tourism, sport and Seasons: the Challenges and Potential of Overcoming Seasonality in the Sport and Tourism Sectors. Tourism Management, vol.23, pp.175-185.

HIGHAM, James. 1996. The Bledisloe Cup: Quantifying the Direct Economic Benefits of Event Tourism, with Ramifications for a City in Economic Transition. Festival Management \& Event Tourism, vol.4, pp.107-116.

HIGHAM, James. 1999. Sport as an Avenue of Tourism Development: an Analysis of the Positive and Negative Impacts of Sport Tourism. Current Issues in Tourism, vol.2, n.1, p.82-90.

HILLER, Harris H. 1989. Impact and Image: the Convergence of Urban Factors in Preparing for the 1988 Calgary Winter Olympics. In SYME et al. Cap.10, pp.119-131.

HIPKINGS, Max. 1989. How Fremantle Coped with the Challenge. In: SYME et al (eds.). The Planning and Evaluation of Hallmark Events. USA, Hong Kong, Singapore, Sydney: Avebury. Cap.5, pp.59-72.

HUGHES, Howawr L. 1993. Olympic Tourism and Urban Regeneration. Festival Management \& Event Tourism, vol.1, pp.157-162.

HULTKRANTZ, L. 2000. Event Economics: Top-Down Approaches. In: MOSSBERG, L.L. (ed.). Evaluation of Events: Scandinavian Experiences. USA, Australia, Japan: Cognizant. Cap.7, pp.104-121.

JAFARI, Jafar (ed.). 2000. Encyclopedia of Tourism. London: Routledge.

JAGO, Leo K. e SHAW, Robin N. 1998. Special Events: a Conceptual and Definitional Framework. Festival Management \& Event Tourism, vol.5, pp.21-32.

JOHNSTON, Margareth E. 1992. Facing the Challenges: Adventure in the Mountains of New Zealand. In: WEILER, B. e HALL, C.M. Special interest Tourism. London: Belhaven. Cap.12, pp.159-169.

KADOTA, Décio K., HADDAD, Eduardo A. e RABAHY, Wilson A. 2003. Impacto Econômico do G.P. Brasil de Fórmula I na Cidade de São Paulo. Turismo em Números, Caderno de Estatísticas, vol.XXXIV, pp.1-8.

KELLY, lan. 1989. The Architecture and Town Planning Associated with a Hallmark Event. In: SYME et al (eds.). The Planning and Evaluation of Hallmark Events. USA, Hong Kong, Singapore, Sydney: Avebury. Cap.22, pp.263-273

KURTZMAN, Joseph, ZAUHAR, John, AHN, Jong-yun e CHOID, Seung-dam. 1993. Global Understanding, Appreciation and Piece through Sports Tourism. Journal of Sport Tourism, vol.1, n.1.

KURTZMAN, Joseph. 2001. Economic Impact: Sport Tourism and the City. Journal of Sport Tourism, vol.6, n.3. 
LANGENBUCH, Juergen Richard. 1976. Apuração e análise do movimento turístico de áreas receptoras a partir de dados de contagem diária de veículos. Rio de Janeiro: Revista Brasileira de Geografia, 38(3):122-185, jul/set.

LANGENBUSC, Jurgen Richard. 1977. Os municípios turísticos do Estado de São Paulo: determinação e caracterização geral. Geografia, 2(3):1-49, abril, 1977.

LAW, Christopher M. 1996. Urban Tourism: Attracting Visitors to Large Cities. USA, England: Mansell, 189p.

LILLEY III, William e DeFRANCO, Laurence J. 1999. The Economic Impacto f the European Grands Prix. Brussels: Federation Internationale de l'Automobile. 93p. Capturado em 2000, http://www.fia.com

LILLEY III, William e DeFRANCO, Laurence J. 1999. The Economic Impacto f the European Grands Prix. Brussels: Federation Internationale de l'Automobile. 39p. Capturado em 2001, http://www.fia.com; http://www.incontext.net

LIRA Filho, João. 1973. Introdução à Sociologia dos Desportos. Rio de Janeiro: Bloch; Brasília: INL, 400p.

LITTLEWOOD, David e WARD, Harry. 1998. The Save Albert Park Campaign: Opposing the Use of Inner-City Public Parkland for the Melbourne Grand Prix. Festival Management \& Event Tourism, vol.5, pp.159-165.

LOBO, 2002. O automóvel: um cluster (globalmente) inovador. Lisboa.

LOPEZ-BERMEJO, Geraldo Asin. 1967. El Deporte como Promocion de Turismo. Madrid: Instituto de Estúdios Turísticos, 377p.

LOWENDAHL, B.R. 2000. Learning Effects - The Case of the Lillehammer Olympic Winter Games 1994. In: MOSSBERG, L.L. (ed.). Evaluation of Events: Scandinavian Experiences. USA, Australia, Japan: Cognizant. Cap.5, pp.63-85

MADDEN, John R. 1999. The Economics of the Sydney Olympics. Australia: Centre for Regional Economic Analysis, University of Tasmania. 28p.

MAGNANE, Georges. 1969. Sociologia do Esporte. São Paulo: Perspectiva,166p.

MANDELL, Richard D. 1984. Sport: a Cultural History. USA: Columbia, 340p.

MASHIACH, Asher. 2001. Sport Tourism in Israel. Journal of Sport Tourism, vol.6, n.3.

MASTERALEXIS, Lisa P., BARR, Carol A. e HUMS, Mary A. (eds.). 1998. Principles and Practice of Sport Management. USA: Aspen, 522p.

MAZITELLI, David. 1989. Major Sport Events in Australia: some Economic, Tourism and Sportsrelated Effects. In: SYME et al (eds.). The Planning and Evaluation of Hallmark Events. USA, Hong Kong, Singapore, Sydney: Avebury. Cap.16, pp.195-201.

MIHALIK, Brian J. 2000. Host Population Perceptions of the 1996 Atlanta Olympics: Support, Benefits and Liabilities. Tourism Analysis, vol.5, pp.49-53.

MOSSBERG, L.L. (ed.). 2000. Event Strategies in Practice. In: Evaluation of Events:

Scandinavian Experiences. USA, Australia, Japan: Cognizant. Cap.9, pp.148-161.

MOSSBERG, L.L. 2000. Effects of Events on Destination Image. In: Evaluation of Events:

Scandinavian Experiences. USA, Australia, Japan: Cognizant. Cap.3, pp.30-46.

MOUNT, Joan e LEROUX, Carole. 1994. Assessing the Effects of a Mega-Event: a Retrospective Study of the Impact of the Olympic Games on the Calgary Business Sector. Festival Management \& Event Tourism, vol.2, pp.15-23.

NEWMAN, Peter W.G. 1989. The Impact of the America's Cup on Fremantle - an Insider's View. In: SYME et al (eds.). The Planning and Evaluation of Hallmark Events. USA, Hong Kong,

Singapore, Sydney: Avebury. Cap.4, pp.46-58.

PALOMEQUE, Francisco L. 1995. La Estrategia del Turismo Metropolitano: el Caso de Barcelona. Estúdios Turísticos, n.126, pp.119-141.

PIRES, Mário Jorge. 2001. 'Off-Road' e Atrativos Culturais. Lazer e Turismo Cultural. São Paulo: Manole. pp.65-71. 
PIRES, Mário Jorge. 2001. Imagem e Cominicação. Lazer e Turismo Cultural. São Paulo: Manole. pp.21-35.

PIRES, Mário Jorge. 2001. O Lazer em São Paulo no Início do Século. Lazer e Turismo Cultural. São Paulo: Manole. pp.81-100.

PRIESTLEY, G.K. 1995. Sports Tourism: the Case of Golf. In: ASHWORTH, G.J. e DIETVORST, A.G.J. (eds.). Tourism and Spacial Transformations: Implications for Policy and Planning. UK: CAB, Cap.12, pp.205-223.

RAMIREZ VIZCARRA, Miguel Ángel. 1990. Turismo Náutico. México: Trillas, 165p.

REDMOND, G. 1991. Changing Styles of Sport Tourism: Industry/Consumer Interations in Canada, the USA and Europe. In: SINCLAIR, M.T. e STABLER, M.J. (eds.). The Tourism Industry: an International Analysis. UK: CAB. Cap.6, pp.107-120.

REIS Filho, Nestor Goulart. 1994. São Paulo e outras Cidades. São Paulo: HUCITEC, 215p.

RITCHIE, B.W. 1996. How Special are Special Events? The Economic Impact and Strategic Development of the New Zealand Masters Games. Festival Management \& Event Tourism, vol.4, pp.117-126.

RITCHIE, B.W. 1998. Bicycle Tourism in the South Island of New Zealand: Planning and Management Issues. Tourism Management, vol.19, n.6, pp.567-582.

RITCHIE, J.R.B. 1984. Assessing the Impact of Hallmark Events: Conceptual and Research Issues. Journal of Travel Research, vol.23, n.1, pp.2-11.

RITCHIE, J.R.B. e AITKEN, Catherine E. 1984. Assessing the Impacts of the 1988 Olympic Winter Games: The Research Program and Initial Results. Journal of Travel Research, vol.22, n.3, pp.17-25.

RITCHIE, J.R.B. e AITKEN, Catherine E. 1985. Olympulse II - Evolving Residents Attitudes Toward the 1988 Olympic Winter Games. Journal of Travel Research, vol.23, n.3, pp.28-33.

RITCHIE, J.R.B. e LYONS, Márcia M. 1987. Olympulse III/Olympulse IV: A Mid-Term Report on Resident Attitudes concerning the XV Olympic Winter Games. Journal of Travel Tourism, vol.26, n.1, pp.18-26.

RITCHIE, J.R.B. e LYONS, Márcia M. 1990. Olympulse VI: A Pos-Event Assessment of Resident Reaction to the XV Olympic Winter Games. Journal of Travel Tourism, vol.28, n.3, pp.14-23.

ROBERT, Peter. 1983. História do Automóvel.

ROBERTS, E.J. e McLEOD, P.B. 1989. The Economics of a Hallmark Event. In: SYME et al (eds.) Cap.20, pp.242-249.

RUBIA, Kátia. 2001. O Imaginário Esportivo Contemporâneo: o Atleta e o Mito do Herói. São Paulo: Casa do Psicólogo, 225p.

RUIZ, Gerard. [1997?]. Lês évolutions des pratiques sportives depuis dix ans - lês grandes tendences actualles. Tourisme et Sport. Cahier Spaces, vol.52, pp.8-14.

SANTOS, Francisco. 2003. Grand Prix: a História da Fórmula Um. Portugal: Talento, 346p.

SASI, Vimala Ko. 1997. Sports Tourism in India. Journal of Sport Tourism, vol.4, n.1.

SHAW, Brian J. 1989. The 'Auld Mug' and the 'Vintage Port' - papers dealing with the Effect of the America's Cup Defence upon Fremantle, W.A.: na Introduction. In: SYME et al (eds.)

Cap.3, pp.43-45.

SHOR, 1999. O automóvel e a cidade de São Paulo. São Paulo: Universidade de São Paulo (Tese).

SIMMONS, David G. e URQUHART, Lorna. 1994. Measuring Economic Effects: an Example of Endurance Sports Events. Festival Management \& Event Tourism, vol.2, pp.25-32.

SOFIELD, Trevor H.B. e SIVAN, Atara. 1994. From Cultural Festival to International Sport: the Hong Kong Dragon Boat Races. Journal of Sport Tourism, vol.1, n.3.

SOUTAR, Geoffrey N. e McLEOD, Paul. The Impact of the America's Cup on Fremantle Residents: some Empirical Evidence. In: SYME et al (eds.). Cap.8, pp.92-102. 
SPARROW, Mark. 1989. A Tourism Planning Model for Hallmark Events. In SYME et al (eds.). Cap.21, pp.250-261.

SPILLING, O.R. 2000. Beyond Intermezzo? On the Long-Term Industrial Impacts of Mega-Events - The Case of Lillehammer 1994. In: MOSSBERG, L.L. (ed.). Evaluation of Events: Scandinavian Experiences. USA, Australia, Japan: Cognizant. Cap.8, pp.122-147.

SPILLING, Olav R. 1998. Beyond Intermezzo? On the Long-Term Industrial Impacts of MegaEvents: the Case Lillehammer 1994. Festival Management \& Event Tourism, vol.5, pp.101-122.

STANDENVEN, Joy e De KNOP, Paul. 1999. Sport Tourism. USA: Human Kinetics, 368p.

STEVENS, T. 1994. Sports Stadia and Arenas: the Sleeping Giants of Tourism. In: SEATON, A.V. (ed.). Tourism - the State of the Art. UK: John Wiley \& Sons. Cap.25, pp.238-245.

TAMBUCCI, Pascoal L. 2000. O Funcionamento do Discurso do Marketing Esportivo em Campanhas Publicitárias e Matérias Jornalísticas (Tese de Doutorado). São Paulo: ECA/USP, 243p.

TCl. La Signora in Rosso. Gênova: /l Centro Documentazione del TCl - Touring Club Italiano, 2003.

THORNE, Ross e MUNRO_CLARK, Margaret. 1989. Hallmark Events as an Excuse for Autocracy in Urban Planning: a case History. In : SYME et al. (eds.). Cap.13, pp.154-171.

Tourisme d'aventure. 1992. Les Cahier Espaces, vol.29, 127p.

Tourisme et Sport. [1997?]. Cahier Espaces, vol.52, 192p.

TOW, Steve. 1994. Sport Tourism: the Benefits. Journal of Sport Tourism, vol.2, n.1.

TULIK, Olga. 1995. Residências Secundárias: presença e expressividade do fenômeno no Estado de São Paulo. São Paulo: Escola de Comunicações e Artes (Tese).

URBAIN, Jean Didier. 1989. The Tourist Adventure and his Images. Annals of Tourism Research, vol.16, pp.106-118.

WALLIS-SMITH, M. 1989. Major International Sporting Events - Characteristics and Criteria for Selection: a South Australian Viewpoint. In: SYME et al (eds.). The Planning and Evaluation of Hallmark Events. USA, Hong Kong, Singapore, Sydney: Avebury. Cap.17, pp.203-213.

WALO, M., BULL, A. e BREEN, H. 1996. Achieving Economic Benefits at Local Events: a Case Study of a Local Sport Event. Festival Management \& Event Tourism, vol.4, pp.95-106.

WHITSON, David e MacINTOSH, Donald. 1996. The Global Circus: International Sport, Tourism and the Marketing of Cities. Journal of Sport \& Social Issues, vol.20, n.3, pp.278-295.

YUSOF, Aminuddin e DOUVIS, John. 2001. An Examination of Sport Tourist Profiles. Journal of Sport Tourism, vol.6, n.3.

ZAUHAR, John e KURTZMAN, Joseph. 1997. Sport Tourism: a Window of Opportunity. Journal of Sport Tourism, vol.4, n.1. 


\section{Sites e Artigos de Jornais e Revistas}

4x4 \& Cia. Ano 9, no.104. São Paulo: Editora ArtPlus.

Agência Estado, 1992. Aumenta a tensão no autódromo. http://www.estadao.com.br, 02abr.

Agência Estado, 1992. Chegam 14 carros para o GP. http://www.estadao.com.br, 24mar.

Agência Estado, 1992. Chegam mais 11 carros. http://www.estadao.com.br, 26mar.

Agência Estado, 1992. GP Brasil: há ingressos para todos os setores. http://www.estadao.com.br, $01 \mathrm{abr}$.

Agência Estado, 1992. Williams e Mclarens viajam lado a lado. http://www.estadao.com.br, 06abr. Agência Estado, 2002. "Circo" da F1 chega a São Paulo. http://www.estadao.com.br, 22mar.

Agência Estado, 2002. Dez motivos para ir até Interlagos. http://www.estadao.com.br, 26mar.

Agência Estado, 2002. Equipamentos da F1 começam a chegar. http://www.estadao.com.br, $21 \mathrm{mar}$.

Agência Estado, 2002. Interlagos recebe equipamento para GP. http://www.estadao.com.br, 20mar.

Agência Estado, 2002. O circo chegando. http://www.estadao.com.br, 25mar.

Agência Estado, 2002. Torcedores lotam Interlagos em treino. http://www.estadao.com.br, 29mar.

Agência Estado, 2002a. F1: compra por telefone acaba amanhã. 2002. Agência Estado, http://www.estadao.com.br, 19mar.

Agência Estado, 2002b. F1: CET define esquema de trânsito. http://www.estadao.com.br, 28mar.

Agência Estado, 2004. Flytour oferece pacotes para o GP Brasil de F1.

http://www.estadao.com.br/turismo/noticias, 09set.

AKIE, Érica. 2002. "Viúvas" de Senna cuidam de Interlagos. Jornal da Tarde, http://www.estadao.com.br, 25mar.

ALVES, Edgard. 2003. Ministério e prefeitura se dizem otimistas. Folha de São Paulo, http://fws.uol.com.br, 07abr.

ALVES, Edgard. 2003. Ministério Público tem liminar cassada de manhã e interpõe recurso à tarde; F1 fala em cancelamento. Folha de São Paulo, http://fws.uol.com.br, 06abr.

ALVES, Edgard. 2003. Questão de publicidade do tabaco e fuga de patrocinadores põe em risco futuro da prova de São Paulo. Folha de São Paulo, http://fws.uol.com.br, 07abr.

AMARAL, André. 2002. Corrida em Interlagos: atrás das obras. Jornal da Tarde, http://www.estadao.com.br, 07mar.

ANDRADE, Castilho de. 1992. Interlagos: todo ano a mesma história. Agência Estado, http://www.estadao.com.br, 02abr.

ANDRADE, Castilho de. 2003. Fórmula 1 comemora medida do governo. O Estado de São Paulo, http://www.estadao.com.br/esportes/noticias, 04abr.

ANDRADE, Castilho. 2003. GP do Brasil de motos está garantido. O Estado de São Paulo, http://www.estadao.com.br/esportes/noticias, 30abr.

Anhembi Turismo e Eventos, 2004. José Carlos Pace: um nome digno da tradição de Interlagos. http://portal.prefeitura.sp.gov.br/secretarias/esportes/interlagos, 11set.

Automóveis Antigos, 2006, Edições 9 e 10. São Paulo: ICB Instituto Brasileiro de Cultura Ltda.

AZEN, Antonio C.; Malinverni. 1998a. Comer; beber; viver... Business Travel, no.19, p.20.

AZEN, Antonio C.; Malinverni. 1998b. Paulicéia da cultura e do lazer. Business Travel, no.19, p.21.

AZEN, Antonio C.; Malinverni. 1998c. São Paulo em velocidade máxima. Business Travel, no.19, p.11-17. 
AZEN, Antonio C.; Malinverni. 1998d. São Paulo, torre de Babel, como a F1. Business Travel, no.19, p.18-19.

BETINI, Bartira. 2005. Interlagos vai abrir para ciclistas. Diário de São Paulo, 12mai, p.A9.

BRAGON, Ranier. 2003. Decisão constrange o Congresso. Folha de São Paulo,

http://fws.uol.com.br, 05abr.

BRUNO, Adriana. 2004. Elas pisam fundo. Primeiramão,

http://primeiramao.com.br/editorial/superauto, 09set.

CALMON, Fernando. 2004. Grito que ecoa. Primeiramão, http://primeiramao.com.br/editorial/superauto, 09set.

CARPINELLI, Rubens A. 2003. Como iniciar no Automobilismo. FASP - Federação de Automobilismo de São Paulo, http://www.faspnet.com.br, $21 \mathrm{fev}$.

CASSIA, Rosana de. 2003. MP libera tabaco na F1; TV adverte. O Estado de São Paulo, http://www.estadao.com.br/noticias, 04abr.

CIOCCARI, Vanice. 2006. Guarulhos pode tirar o GP Brasil de Interlagos. O Estado de São Paulo, http://www.estadao.com.br, 24out.

Clube Santamariense de Automobilismo, 2004. Autódromo Santa Maria, um sonho realizado. http://www.csasm.com.br, 28 e 29ago.

CUNHA, Tatiana. 2003. F1 retira veto à publicidade de cigarro. Folha de São Paulo, http://fws.uol.com.br.

CUNHA, Tatiana. 2003. Piloto do safety vira estrela. Folha de São Paulo, http://fws.uol.com, 07abr.

Diário de Penápolis, 2004. Idealismo: jovem desenvolve projeto para Autódromo em Penápolis. http://www.diariodepenapolis.com.br, 27jun.

DIEGO, Marcelo. 1998. O GP é um bom negócio para São Paulo? Folha de São Paulo, 06mar, cad.3 p.14.

DUARTE, Alec. 2004. A incrivel saga dos nossos brazucas. Gazeta Esportiva, http://search/gazetaesportiva.net/historia/seculo/auto/abertura.htm, 15set.

Federação de Automobilismo de São Paulo, 2004. Encontro Tuning no Autódromo. http://www.faspnet.com.br/edit, 16nov.

Folha de São Paulo, 2000. Padre Marcelo leva milhares a showmissa. 03nov, p.A8.

Folha de São Paulo, 2003. Interlagos de cara nova. http://www.folha.com.br, 06abr.

Folha de São Paulo, 2003. Para quem vai a Interlagos. http://www.folha.com.br, mar.

Folha de São Paulo, 2003. Senna terá exposição interativa em 2004. http://www.folha.com.br, 22out.

Folha de São Paulo, 2004. Novo GP Brasil de F1 atende a pressão de promotor. http://www.estadao.com.br, 31mar.

Folha de São Paulo, 2004. Petrobrás acerta para construir arquibancada em Interlagos. http://www.folha.com.br, 30mar.

Folha de São Paulo, 2004. Por segurança, GP Brasil de F1 deu fim a acampamentos. 29mai.

Folha de São Paulo, 2004. Sem garantia financeira, Brasil renova GP de F1 até 2009.

http://www.estadao.com.br, 30mar.

Fora de Estrada, 2001, ano IV, edição 28. São Paulo: ArtPrinter/Promoven.

Fora de Estrada, 2002, ano V, edição 37. São Paulo: ArtPrinter/Promoven.

FRANCO, Edson. 2000. Férias sobre rodas. Folha de São Paulo, 02jul, Veículos1, p.1-16.

FRAZÃO, Daniel. 2004. Senna: oito anos de uma saudade. Gazeta Esportiva, http://search/gazetaesportiva.net 16 set.

GABEIRA, Fernando. 2000. Encontros de motos geram turismo onde ninguém espera. Folha de São Paulo, 10jul, p.G15. 
GALBRAITH, Robert. 2004. Correndo por fora - Rubens Barrichello, vice-campeão em $2002 \mathrm{e}$ 2004, não estrela campanhas na TV há quase cinco anos. Meio \& Mensagem, 18out, p.56.

GALBRAITH, Robert. 2004. Fórmula 1 encerra temporada com audiência 10\% menor. Meio \& Mensagem, 18out, p.56.

Gazeta Esportiva, 2004. A categoria mais antiga do mundo. http://search/gazetaesportiva.net 16 set.

Gazeta Esportiva, 2004. As donas do show. http://search/gazetaesportiva.net 16set.

Gazeta Esportiva, 2004. Aventura de um século. http://search/gazetaesportiva.net 16set.

Gazeta Esportiva, 2004. Com o povo em suas mãos. http://search/gazetaesportiva.net 16set.

Gazeta Esportiva, 2004. Emoção fora da badalação. 16set.

Gazeta Esportiva, 2004. Os grandes ídolos. http://search/gazetaesportiva.net, 16 set.

Gazeta Esportiva, 2004. Os trágicos acidentes. http://search/gazetaesportiva.net, 16set.

Gazeta Esportiva, 2004. Rali dos Sertões: trajeto mais curto em disputa mais inchada. jun.

Gazeta Esportiva, 2004. Sonho em quatro rodas. http://search/gazetaesportiva.net, 16 set.

Gazeta Esportiva, 2004. Superação do medo. http://search/gazetaesportiva.net, 16 set.

Gazeta esportiva, 2004. Um polêmico tricampeão. http://search/gazetaesportiva.net 16set.

Gazeta Mercantil, 1997. A Fórmula 1 S.A. sinaliza uma nova era. 30set, p.C5.

Gazeta Mercantil, 1997. Wall Street descobre a alta velocidade. 30set, p.C5.

GONZALEZ, Wagner. 2000. Luxo e festa nos bastidores de Mônaco. Gazeta Mercantil, 2,3 e 4jun, p.2.

GP Brasil de Fórmula 1, 2004. Declaração dos Organizadores do GP Brasil F1. http://www.gpbrasil.com.br, 11mar.

GP Brasil de Fórmula 1, 2004. Prefeitura renova contrato da Fórmula 1 em São Paulo. http://www.gpbrasil.com.br, 07abr.

GP Brasil de Fórmula 1, 2004. Primeiro ingresso vai para comerciante de São Paulo. http://www.gpbrasil.com.br, 05jul.

GP Brasil de Fórmula 1, 2007. http://www.gpbrasil.com.br

Grupo Estado, 2006. Arrastão acontece na região do Autódromo de Interlagos.

http://www.estadao.com.br, 20out.

Informe Sergipe, 2002. Mitsubishi Motorsports Nordeste 2002 começa hoje. http://www.informesergipe.com.br 17mai.

Informe Sergipe, 2004. Rally do Café contará pontos para o prêmio Goodyear Off Road. http://www.informesergipe.com.br 02set.

Informe Sergipe, 2004. Rallye do Agreste começa neste sábado em Fortaleza. http://www.informesergipe.com.br 09set.

Informe Sergipe, 2004. Turismo automobilístico na Europa. http://www.informesergipe.com.brl, 22mar.

ISHIKAWA, Márcio. 2002. Convidado de honra, Pelé não dá bandeirada da vitória. Grid, http://grid.abril.com.br/noticias, 01abr.

ISHIKAWA, Márcio. 2003a. Áustria deve perder GP a partir do ano que vem. Grid, http://grid.abril.com.br/noticias, 27jan.

ISHIKAWA, Márcio. 2003b. Bahrein enfrenta problemas em seu projeto de F1. Grid, http://grid.abril.com.br/noticias, 05fev.

ISHIKAWA, Márcio. 2003c. Barrichello tanta manter tabu do GP Brasil. Grid, http://grid.abril.com.br/noticias, 02abr.

ISHIKAWA, Márcio. 2003d. Canadá retorna ao calendário da F1. Grid,

http://grid.abril.com.br/noticias, 15 out. 
ISHIKAWA, Márcio. 2003e. Coréia do Sul pode ser o próximo passo da F1. Grid, http://grid.abril.com.br/noticias, 22out.

ISHIKAWA, Márcio. 2003e. Corrida no Canadá pode voltar a ser cancelada. Grid, http://grid.abril.com.br/noticias, 04nov.

ISHIKAWA, Márcio. 2003g. FIA anuncia medidas de redução de custos. Grid, http://grid.com.br/noticias, 15jan.

ISHIKAWA, Márcio. 2003h. FIA anuncia mudanças para a temporada 2004. Grid, http://grid.com.br/noticias, 15 out.

ISHIKAWA, Márcio. 2003i. FIA apenas "recomenda" fim da propaganda de cigarros. Grid, http://grid.com.br/noticias, 25jun.

ISHIKAWA, Márcio. 2003j. FIA marca inspeção oficial em Interlagos. Grid, http://grid.abril.com.br/noticias, 29jan.

ISHIKAWA, Márcio. 2003k. FIA vai entrar na Justiça contra fim da propaganda de cigarros. Grid, http://grid.com.br/noticias, 03abr.

ISHIKAWA, Márcio. 2003I. FIA vistoria Interlagos e detalha "parque fechado". Grid, http://grid.abril.com.br/noticias, $17 \mathrm{fev}$.

ISHIKAWA, Márcio. 2003m. Fórmula 1 pode ter prova em Nova York. Grid, http://grid.abril.com.br/noticias, 03nov.

ISHIKAWA, Márcio. 2003n. Globo ameaçada de perder Fórmula 1 para o SBT. Grid, http://grid.com.br/noticias, 26mar.

ISHIKAWA, Márcio. 2003o. GP da França deve ser cancelado em 2004. Grid, http://grid.abril.com.br/noticias, 21 nov.

ISHIKAWA, Márcio. 2003p. GP do Canadá ainda depende de recursos. Grid, http://grid.abril.com.br/noticias, 21out.

ISHIKAWA, Márcio. 2003q. GP do Canadá está garantido, diz jornal. Grid, http://grid.abril.com.br/noticias, 18nov.

ISHIKAWA, Márcio. 2003r. GP dos Estados Unidos de 2004 será em junho. Grid, http://grid.abril.com.br/noticias, 01ago.

ISHIKAWA, Márcio. 2003s. Ingressos de 3 setores do GP Brasil já esgotados. Grid, http://grid.com.br/noticias, 22jan.

ISHIKAWA, Márcio. 2003t. Ingressos do GP Brasil começam a ser entregues. Grid, http://grid.com.br/noticias, 19mar.

ISHIKAWA, Márcio. 2003u. Interlagos sediará centenário da F1 em 2003. Grid, http://grid.abril.com.br/noticias, $07 \mathrm{fev}$.

ISHIKAWA, Márcio. 2003v. Justiça suspende GP Brasil de 2004. Grid, http://grid.com.br/noticias, 10nov.

ISHIKAWA, Márcio. 2003w. Ministro confirma que a FIA fez pressão no GP Brasil. Grid, http://grid.com.br/noticias, 14mai.

ISHIKAWA, Márcio. 2003x. Liminar que impedia GR Brasil é suspensa. Grid, http://grid.com.br/noticias, $01 \mathrm{dez}$.

ISHIKAWA, Márcio. 2003z. Prefeitura tenta suspender liminar que cancelou Grande Prêmio. Grid, http://grid.com.br/noticias, 12nov.

ISHIKAWA, Márcio. 2003za. Procura por ingressos do GP Brasil aumenta após prova em Melbourne. Grid, http://grid.com.br/noticias, 11mar.

ISHIKAWA, Márcio. 2003zb. Propaganda de cigarro gera polêmica no GP Brasil. Grid, http://grid.com.br/noticias, 02abr.

ISHIKAWA, Márcio. 2003zc. Público do GP Brasil foi maior que em 2003. Grid, http://grid.com.br/noticias, 09abr.

ISHIKAWA, Márcio. 2003zd. Spa deve voltar ao calendário da F1. Grid, http://grid.abril.com.br/noticias, 24jul. 
ISHIKAWA, Márcio. 2003ze. Spa-Francorchamps pode voltar ao calendário em 2004. Grid, http://grid.abril.com.br/noticias, 24abr.

ISHIKAWA, Márcio. 2003zf. Treino classificatório pode mudar em 2004. Grid, http://grid.com.br/noticias, 03out.

ISHIKAWA, Márcio. 2003zg. Três mil homens farão o policiamento do GP Brasil. Grid, http://grid.com.br/noticias, 31mar.

ISHIKAWA, Márcio. 2004a. Equipes podem boicotar provas européias. Grid, http://grid.com.br/noticias, 20jan.

ISHIKAWA, Márcio. 2004b. Ferrari vai lutar para manter Ímola no calendário da F1. Grid, http://grid.abril.com.br/noticias, 27abr.

ISHIKAWA, Márcio. 2004c. FIA apresenta pacote de mudanças radicais para 2008. Grid. http://grid.com.br/noticias, 23abr.

ISHIKAWA, Márcio. 2004d. FIA defende calendário com 16 provas. Grid, http://grid.com.br/noticias, 03fev.

ISHIKAWA, Márcio. 2004e. FIA quer reduzir velocidade dos carros. Grid, http://grid.com.br/noticias, 08abr.

ISHIKAWA, Márcio. 2004f. FIA reserva 19 datas para o calendário 2005 da F1. Grid, http://grid.com.br/noticias, 01jun.

ISHIKAWA, Márcio. 2004g. FIA vai ter novo sistema de qualificação e regras para o safety-car. Grid, http://grid.com.br/noticias, 31mai.

ISHIKAWA, Márcio. 2004h. França é confirmada no calendário de 2004. Grid, http://grid.abril.com.br/noticias, 16jan.

ISHIKAWA, Márcio. 2004i. Globo não vai mais arcar com custos do GP do Brasil, diz jornal. Grid. http://grid.com.br/noticias, 31mar.

ISHIKAWA, Márcio. 2004j. Ingressos do Grande Prêmio do Brasil já estão à venda. Grid, http://grid.com.br/noticias, 22mar.

ISHIKAWA, Márcio. 2004k. Lei provoca bate-boca entre FIA e União Européia. Grid, http://grid.com.br/noticias, 21out.

ISHIKAWA, Márcio. 2004I. Pista de Interlagos começa a passar por recuperação. Grid, http://grid.com.br/noticias, 15 set.

ISHIKAWA, Márcio. 2004m. SP renova contrato com a Fórmula 1 até 2009. Grid, http://grid.com.br/noticias, 31mar.

ISHIKAWA, Márcio. 2007. Por prova noturna, Bernie dá ultimato para GP da Austrália. Grid, http://quatrorodas.abril.com.br/grid/noticias, 21mai.

JHM. 1998. Carne e mulheres fazem a fama. Folha de São Paulo, 28mar, p.3-17.

Jornal da Tarde, 2002. F3000: aperitivo no GP do Brasil. http://www.estadao.com.br, $14 f e v$.

Jornal da Tarde, 2002. Grande Prêmio do cachorro-quente. http://www.estadao.com.br, 10mar.

Jornal da tarde, 2002. Negócios a $300 \mathrm{Km} / \mathrm{h}$. http://www.estadao.com.br, 10mar.

Jornal da Tarde, 2002. O Autódromo que pode virar parque. http://www.estadao.com.br, 10mar.

Jornal da Tarde, 2002. Quanto vale o show, Ecclestone? http://www.estadao.com.br, 10mar.

Jornal da Tarde, 2002. SP tem feira para fãs do automobilismo. http://www.estadao.com.br, 23mar.

Jornal da Tarde, 2002a. Interlagos: eterno canteiro de obras. http://www.estadao.com.br, 27mar.

KELLER, Arnaldo. 2004. Mil Milhas Brasileiras. Primeiramão,

http://primeiramao.com.br/editorial/superauto, $15 \mathrm{nov}$.

LEITE, Almir. 2002a. Obras em Interlagos seguem atrasadas. O Estado de São Paulo, http://www.estadao.com.br, 14mar.

LEITE, Almir. 2002b.GP Brasil: reforço da informática. O Estado de São Paulo, http://www.estadao.com.br, 15mar. 
LEITE, Almir. 2002c. Dia tranqüilo no QG da Fórmula 1. O Estado de São Paulo, http://www.estadao.com.br, 27mar.

Locação ABLA, 2005. Interlagos terá gestão privada. Rev. Associação Brasileira das Locadoras de Automóveis, mai/jun, p.11.

MARIANTE, José Henrique. 1997. F1 retorna hoje às origens na Bélgica. Folha de São Paulo, 24ago.

Meio \& Mensagem, 2004. Netza abre cotas por história do automobilismo. 02abr.

Meio \& Mensagem, 2004. Pop Com cria promoção online da Schincariol. set.

Meio \& Mensagem, 2004. Sight Momentum organiza exposição Senna Experience. 18out, p56.

MIRÁS, Denise. 2004. F1: Ótimo negócio para São Paulo. Folha de São Paulo,

http://www.estadao.com.br, 14jul.

NEVES, Crislane. 2002a. Interlagos é testado para o GP Brasil. Jornal da Tarde, http://www.estadao.com.br, $16 \mathrm{fev}$.

NEVES, Crislane. 2002b. Interlagos passa por ensaio geral. Jornal da Tarde, http://www.estadao.com.br, 16mar.

NEVES, Crislane. 2002c. Médico chega, mas helicóptero não voa. Jornal da Tarde, http://www.estadao.com.br, 17mar.

O Estado de São Paulo, 2001. Só Indianópolis liga para a F1 nos EUA. http://www.estadao.com.br/esportes/noticias, 01out.

O Estado de São Paulo, 2002. F1 abre discussão para reduzir custos. http://www.estadao.com.br, 18mar.

O Estado de São Paulo, 2002. Interlagos recebe sinal verde da FIA. http://www.estadao.com.br, 28mar.

O Estado de São Paulo, 2003. França deve ter seu GP de F1 em julho.

http://www10.estadao.com.br/esportes/noticias, $12 \mathrm{dez}$.

O Estado de São Paulo, 2004. Lei antitabaco põe Ferrari em xeque.

http://www.estadao.com.br/esportes/automobilismo/noticias, 09set.

O Estado de São Paulo, 2006. Cabreúva vai ganhar autódromo de R\$ 42 milhões. 2006. http://www.estadao.com.br, 24mai.

O Estado de São Paulo, 2006. Segurança reforçada para GP Brasil. http://www.estadao.com.br, 28mai.

O Estado de São Paulo, 2007. Bahrein estende contrato e terá GP da Fórmula 1 até 2013. http://www.estadao.com.br, 29jan.

O Estado de São Paulo, 2007. Ecclestone quer corrida noturna na Austrália. http://www.estadao.com.br, 20mai.

O Estado de São Paulo, 2007. F1 pode recorrer a biocombustível no futuro. http://www.estadao.com.br/esportes/formula1, 18mai.

O Estado do Paraná, 2004. Copa Turismo GNV tem etapa em Curitiba. http://ctgas.com.br, 09set.

OHATA, Eduardo e RIBEIRO, Lúcio. 2003. GP gera corrida ao sexo em São Paulo. http://www.folha.com.br, 06abr.

OLIVEIRA, Vinícius de. 2007. Divulgados os preços dos ingressos para o GP Brasil. Grid, http://quatrorodas.abril.com.br/grid/noticias, 15mai.

ORICCHIO, Lívio. 2002a. Interlagos terá reformas maiores. O Estado de São Paulo, http://www.estadao.com.br, 07fev.

ORICCHIO, Lívio. 2002b. Interlagos servirá de cobaia para FIA. O Estado de São Paulo, http://www.estadao.com.br, 24mar.

ORICCHIO, Lívio. 2002c. Tudo calmo em Interlagos, diz diretor. O Estado de São Paulo, http://www.estadao.com.br, 25mar. 
ORICCHIO, Lívio. 2002d. Interlagos será inspecionado nesta 4a . O Estado de São Paulo, http://www.estadao.com.br, 26mar.

ORICCHIO, Lívio. 2002e. FIA exige obras mais extensas em Interlagos. O Estado de São Paulo, http://www.estadao.com.br, 08fev.

ORICCHIO, Lívio. 2003. F1: juiz nega revisão da liminar. O Estado de São Paulo, http://www.estadao.com.br, 14nov.

ORICCHIO, Lívio. 2004a. Regulamento da F1: reprovação total. O Estado de São Paulo, http://www.estadao.com.br/esportes/noticias, 07mar.

ORICCHIO, Lívio. 2004b. Rali: Mitsubishi comemora evolução. O Estado de São Paulo, http://www.estadao.com.br/esportes/automobilismo, 02ago.

ORICCHIO, Lívio. 2007. GP do Brasil de F1 num novo autódromo, em Guarulhos. Possível. O Estado de São Paulo, http://www.estadao.com.br, 04mai.

PAULA, Carlos de. 2007. Prova Rodovia do Café.

http://www.brasilianlists.com/automobilismo3.html, fev.

Primeiramão, 2003. Rally dos Sertões mostra o Brasil.

http://primeiramao.com.br/editorial/superauto, 24abr.

Primeiramão, 2003. Rally Urbano. http://primeiramao.com.br/editorial/superauto, 08mai.

Primeiramão, 2004. Clássicos, ralis e esportivos argentinos.

http://primeiramao.com.br/editorial/superauto, 15nov.

Renault Speed Show, 2004. Uma maneira positiva de promover a cidade. 2004.

http://www.speedshow.com.br, 15set.

Revista Grid, 2002. 3 mil pessoas vão fazer a segurança em Interlagos. http://grid.abril.com.br/noticias, 09mar.

Revista Grid, 2002. Área exclusiva para deficientes em Interlagos. http://grid.abril.com.br/noticias, 13mar.

Revista Grid, 2002. Carros da Fórmula 1 já estão em Interlagos. http://grid.abril.com.br/noticias, 23mar.

Revista Grid, 2002. Ensaio de resgate do GP Brasil bate recorde. http://grid.abril.com.br/noticias, 08mar.

Revista Grid, 2002. Equipamentos da F1 desembarcam em São Paulo.

http://grid.abril.com.br/noticias, 20mar.

Revista Grid, 2002. FIA elogia novas áreas de escape de Interlagos. http://grid.abril.com.br/noticias, 28mar.

Revista Grid, 2002. Tecnologia de ponta para o GP Brasil. http://grid.abril.com.br/noticias, 15mar.

Revista Grid, 2002a. 100 mil pneus vão proteger os pilotos em Interlagos. http://grid.abril.com.br/noticias, 07mar.

Revista Grid, 2002b. Simulado testa atendimento médico em Interlagos. http://grid.abril.com.br/noticias, 14mar.

Revista Grid, 2002c. Definidos pilotos dos carros de intervenção no Brasil. http://grid.abril.com.br/noticias, $11 \mathrm{mar}$.

Revista Grid, 2002c. Tranqüilidade marca GP Brasil. http://grid.abril.com.br/noticias, 01abr.

Revista Grid, 2003. Carros antigos desfilarão com números históricos. http://grid.com.br/noticias, 28mar.

Revista Grid, 2003. FIA divulga datas das provas na temporada 2004. http://grid.com.br/noticias, 25jun.

Revista Grid, 2003. GP Brasil vai homenagear memória do automobilismo nacional. http://grid.com.br/noticias, $18 \mathrm{fev}$.

Revista Grid, 2007. Retratos de uma paixão.

http://quatrorodas.abril.com.br/grid/especiais/retratos.shtml, 25mai. 
RIBEIRO, Lúcio. 2003a. Chuva é diferente para vips e 'família G'. Folha de São Paulo, http://fws.uol.com, 07abr.

RIBEIRO, Lúcio. 2003b. Domingo tem quebra de carros e de recordes. Folha de São Paulo, http://fws.uol.com, 07abr.

SALIBIAN, Greg. 2000a. Ingressos para o GP já estão esgotados. Folha de São Paulo, 18set, p.G3.

SALIBIAN, Greg. 2000b. Rumo a Indianápolis. Folha de São Paulo, 18set, p.G1-2.

SAMPAIO, Paulo. 2004a. Comissões reforçam ganho de taxistas. Folha de São Paulo, 23out, p.C3.

SAMPAIO, Paulo. 2004b. Corrida e eventos agitam mercado da noite. Folha de São Paulo, 23out, p.C1.

SAMPAIO, Paulo. 2004c. GP Brasil atrai prostitutas à cidade. Folha de São Paulo, 23out, p.C3.

SANTOS, Cibele. 2004. FIA reage a ameaça contra F1. Meio \& Mensagem, 28abr.

São Paulo Convention \& Visitors Bureau, 2004. Promoções GP Brasil de F1.

http://www.visitesaopaulo.com, 16 set.

SBI - Sociedade de Benfeitores de Interlagos, 2007. http://www.sbinterlagos.org.br

SEIXAS, Fábio, MARIANTE, José H.; DANTAS, luri. 2003. Por decreto, governo Lula abre GP a cigarro até 2005. Folha de São Paulo, http://fws.uol.com.br, 05abr.

SEIXAS, Fábio. 2001. F1 tenta evitar GP nos EUA. Folha de São Paulo, 14set, p.D1.

SEIXAS, Fábio. 2003a. FIA reabilita corrida sem cigarro e ratifica a nova classificação. Folha de São Paulo, http://fws.uol.com.br, 16out.

SEIXAS, Fábio. 2003b. Jornais dizem que caos no GP foi 'histórico'. Folha de São Paulo, http://fws.uol.com, 08abr.

SEIXAS, Fábio. 2003c. Montezemolo ataca corrida. Folha de São Paulo, http://fws.uol.com, 08abr.

SEIXAS, Fábio. 2003e. Prefeitura pede data no final da temporada da F1 em 2004.

http://www.folha.com.br.

SEIXAS, Fábio. 2004. Por omissão, GP vai ter cigarro. Folha de São Paulo, http://www.folha.com.br, 03abr.

SEIXAS, Fábio; CUNHA, Tatiana. 2003. Pela $1^{\text {a }}$. vez, Interlagos é aprovado totalmente. Folha de São Paulo, http://www.folha.com.br, 04abr.

SEIXAS, Fábio; MARIANTE, José H. 2003a. Carta de ministro ratifica GP Brasil sem lei do cigarro. Folha de São Paulo, http://fws.uol.com.br, 04abr.

SEIXAS, Fábio; MARIANTE, José H. 2003b. Com chuvas, a 'curva do Sol' apavorou o GP. Folha de São Paulo, http://www.folha.com.br, 07abr.

SEIXAS, Fábio; MARIANTE, José H. 2003c. É um ajuste, diz prefeitura. Folha de São Paulo, http://fws.uol.com.br, 05abr.

SEIXAS, Fábio; MARIANTE, José H. 2003d. Globo diz que apenas acata a lei. Folha de São Paulo, http://fws.uol.com.br, 05abr.

SEIXAS, Fábio; MARIANTE, José H. 2003e. Nova data para proibição desafia calendário da FIA. Folha de São Paulo, http://fws.uol.com.br, 05abr.

SEIXAS, Fábio; MARIANTE, José H. 2003g. Sem começo, sem fim. Folha de São Paulo, http://www.folha.com.br, 07abr, p.D1.

SEIXAS, Freitas. 1998. Turismo Sexual invade até o programa oficial do GP. Folha de São Paulo, 28mar, p.3-17.

SEIXAS, Freitas. 2003f. Às vésperas da eleição municipal, São Paulo terá "GP do PT". Folha de São Paulo, http://www.folha.com.br, 12set.

Speed Racing. 2007. História das Categorias. http://speedracing.v10.com.br 
SPTuris - São Paulo Turismo, 2006. Ação Global no autódromo de Interlagos. Informativo Autódromo de Interlagos, http://prefeitura.sp.gov.br/noticias, 23mar.

SPTuris - São Paulo Turismo, 2007. A história do Autódromo “José Carlos Pace". http://www.autodromointerlagos.com, 19mai.

SPTuris - São Paulo Turismo, 2007. Ayrton Senna Racing Day será dia 19 de novembro. Boletim Autódromo de Interlagos "José Carlos Pace". http://www.anhembi.com.br, 19mai.

SPTuris - São Paulo Turismo, 2007. http://www.autodromointerlagos.com

TERRAZ, Regina. 2005a. Pista livre para a iniciativa privada explorar o Autódromo de Interlagos. Diário de São Paulo, 26jun, p.A3.

TERRAZ, Regina. 2005b. Serra quer corridas e parque no local. Diário de São Paulo, 26jun, p.A3.

VALDEJÃO, Renata de Gáspari. 2000. Para Fittipaldi, GP beneficia a cidade e a F1. Folha de São Paulo, 18set, p.G4.

VIDIGAL, Alberto de Camargo. 2002. O turismo sobre quatro rodas. O Estado de São Paulo, 26mar, p.V2.

ZUKERAN, Valéria. 2002a. Interlagos pronto para teste da FIA. O Estado de São Paulo, http://www.estadao.com.br, 27mar.

ZUKERAN, Valéria. 2002b. Na F1, peruas substituem ambulâncias. O Estado de São Paulo, http://www.estadao.com.br, 28mar. 